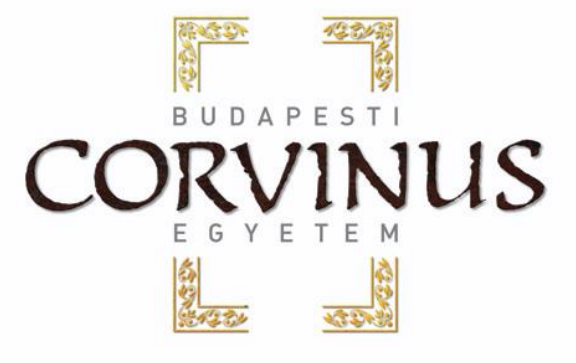

\title{
Mikrobiális fitáz enzim előállítása és jellemzése
}

\author{
Doktori értekezés
}

\section{BUJNA ERIKA}

Témavezető: Rezessyné Dr. Szabó Judit egyetemi magántanár

Budapest

2014 


\section{A doktori iskola}

megnevezése: Élelmiszertudományi Doktori Iskola

tudományága: Élelmiszertudományok

vezetője: Dr. Felföldi József, egyetemi tanár, $\mathrm{PhD}$

Budapesti Corvinus Egyetem

Témavezető: Rezessyné Dr. Szabó Judit, egyetemi magántanár, $\mathrm{PhD}$

Sör- és Szeszipari Tanszék

Élelmiszertudományi Kar

Budapesti Corvinus Egyetem

\section{A doktori iskola- és a témavezető jóváhagyó aláírása:}

A jelölt a Budapesti Corvinus Egyetem Doktori Szabályzatában elöírt valamennyi feltételnek eleget tett, a mühelyvita során elhangzott észrevételeket és javaslatokat az értekezés átdolgozásakor figyelembe vette, ezért az értekezés védési eljárásra bocsátható. 
A Budapesti Corvinus Egyetem Élettudományi Területi Doktori Tanácsának 2014. október 7.i határozatában a nyilvános vita lefolytatására az alábbi bíráló Bizottságot jelölte ki:

\section{BÍRÁLÓ BIZOTTSÁG:}

Elnöke

Farkas József, MHAS, BCE

\section{Tagjai}

Biacs Péter, DSc, BCE

Vereczkey Gábor, CSc, ny.

Halász Anna, DSc, NAIK-ÉKI

Beczner Judit, CSc, NAIK-ÉKI

Dernovics Mihály, $\mathrm{PhD}, \mathrm{BCE}$

Opponensek

Kosáry Judit, DSc, BCE

Dobolyi Csaba, CSc, SZIE

Titkár

Kun-Farkas Gabriella, PhD, BCE 



\section{TARTALOMJEGYZÉK}

1. BEVEZETÉS

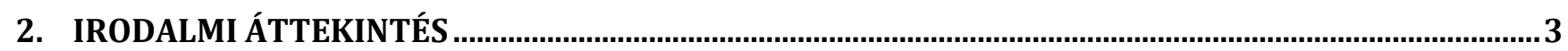

$2.1 \quad$ A FONALAS GOMBÁK JELENTŐSÉGE ÉS JELLEMZÉSE................................................................................. 3

2.1.1 Az Aspergillus niger jellemzése …....................................................................................................

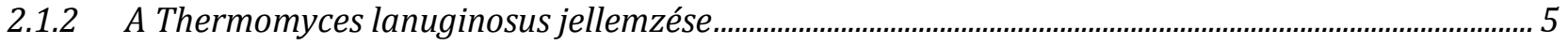

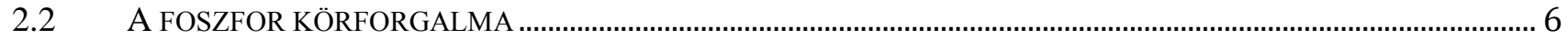

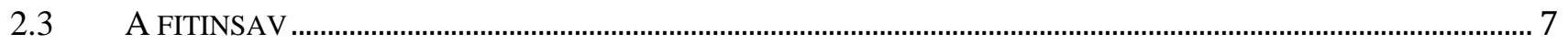

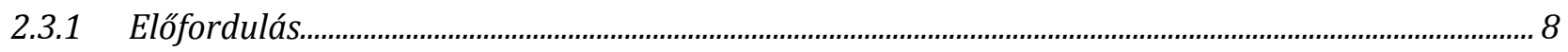

2.3.2 A fitinsav táplálkozásélettani jelentősége ............................................................................................10

2.3.2.1 Antinutritív jelleg........................................................................................................................................................... 10

2.3.2.2 A fitinsav és a mioinozit-foszfátok jótékony hatásai ..................................................................................................................13

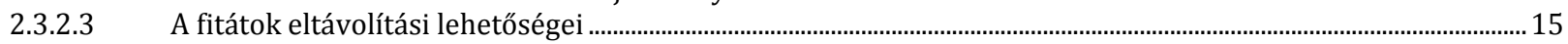

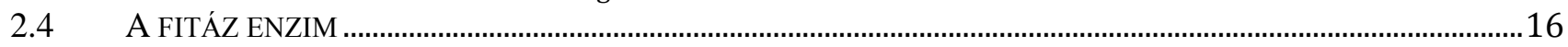

2.4.1 Osztályozás...............................................................................................................................................................16

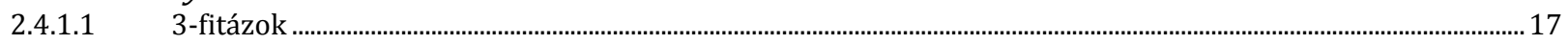

2.4.1.2 4/6-fitázok ................................................................................................................................................................................ 18

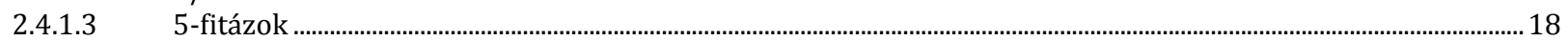

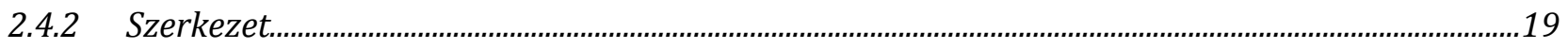

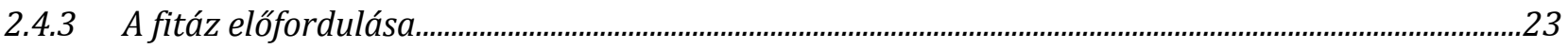

2.4.3.1 Növényi eredetú fitázok ....................................................................................................................................................................2 24

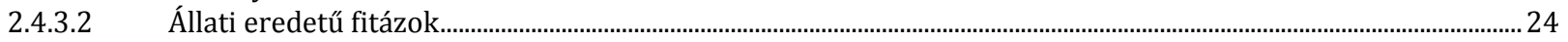

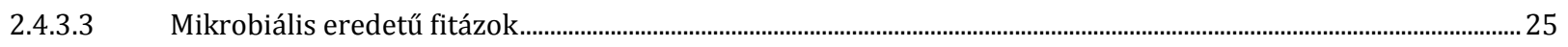

2.4.4 A fitáz szintézisét befolyásoló tényezók …………................................................................................26

2.4.4.1 A foszfor koncentráció hatása ............................................................................................................................................26

2.4.4.2 Az inokulum és a tápközeg összetétel hatása ...................................................................................................................27

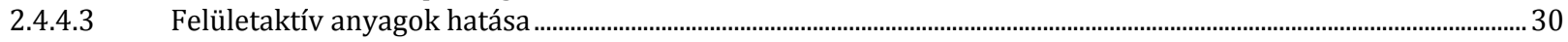

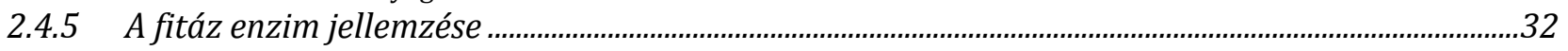

2.4.5.1 Szubsztrát specifitás.........................................................................................................................................................................33

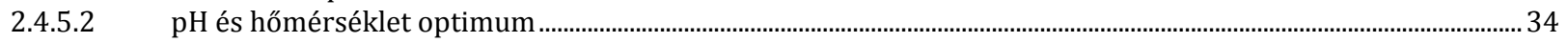

2.4.5.3 Aktivátorok, inhibitorok .................................................................................................................................................................................... 36

2.4.6 A fitáz enzim biotechnológiai hasznosíthatósága ….............................................................................38

2.4.6.1 A fitáz alkalmazása a takarmányozásban .......................................................................................................................................... 38

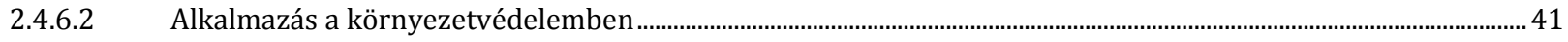

2.4.6.3 Alkalmazás az emberi táplálkozásban............................................................................................................................................ 41

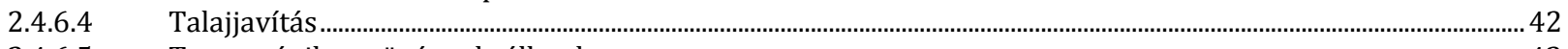

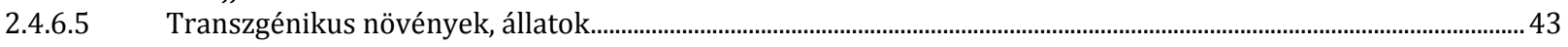

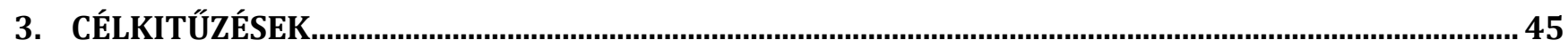

4. ANYAGOK ÉS MÓDSZEREK

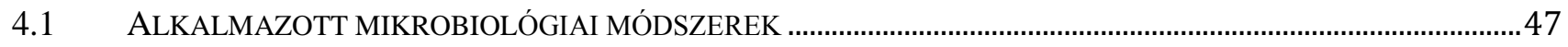

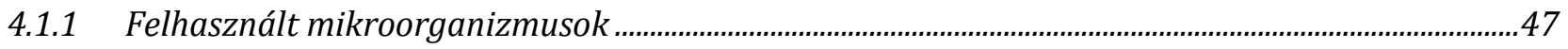

4.1.2 Alkalmazott tápközegek összetétele …………….................................................................................47

4.1.3 Tenyésztési módszerek, körülmények …….......................................................................................49

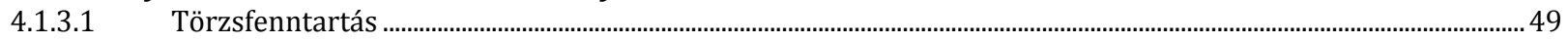

4.1.3.2 Inokulum tenyészet készítése................................................................................................................................................ 49

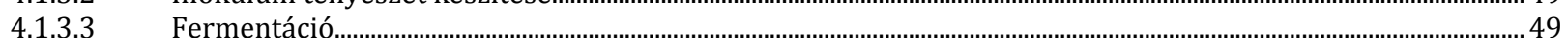

4.2 ALKALMAZOTT OLDATOK, PUFFEREK .....................................................................................................50

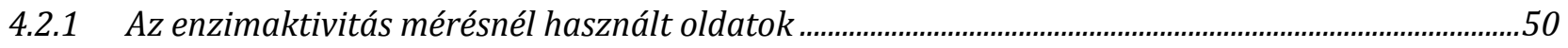

4.2.2 Alkalmazott pufferek és reagensek (RAUEN 1964)...........................................................................50

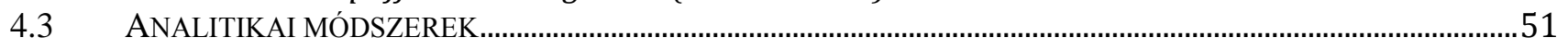

4.3.1 Enzimaktivitás meghatározásának módszere................................................................................51

$4.4 \quad$ FEHÉRJE MEGHATÁROZÁSI MÓDSZEREK ………..........................................................................................52

4.4.1 280 nm-en történő fényelnyelésen alapuló módszer ..........................................................................52

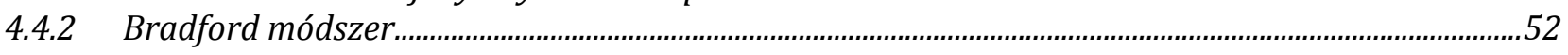

4.4.3 Kromatográfiás módszerek …..........................................................................................................................53 
5. EREDMÉNYEK ÉS ÉRTÉKELÉSÜK.

5.1 THERMOMYCES LANUGINOSUS EREDETÜ FITÁZ ENZIM ELÖÁLLÍTÁSA.......................................................57

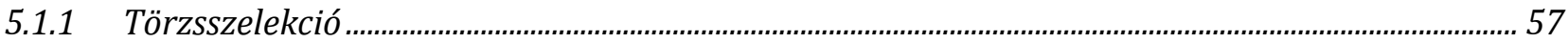

5.1.2 Tápközeg összetétel optimálása.................................................................................................... 58

5.1.2.1 Tápközeg pH-jának hatása a fitáz termelésre................................................................................................................................ 58

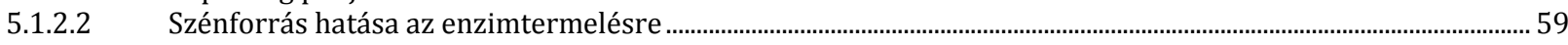

5.1.2.3 A hőmérséklet hatása a fitáz enzim aktivitására..................................................................................................................... 61

5.1.2.4 A rizsliszt koncentrációjának hatása a fitáz aktivitásra.................................................................................................................. 62

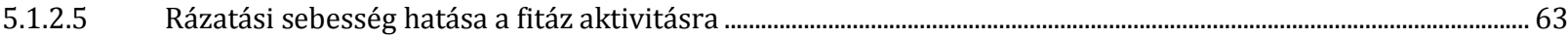

5.1.2.6 Különböző tápkomponensek hatása az aktivitásra …......................................................................................................................... 65

5.1.2.7 Felületaktív anyagok hatása................................................................................................................................................... 66

5.1.2.8 Az inokulum tenyészet korának hatása az enzimtermelésre................................................................................................... 68

5.2 A TERMOFIL THERMOMYCES LANUGINOSUS EREDETU゙ FITÁZ ENZIM TISZTÍTÁSA ......................................... 69

5.3 A TERMOFIL THERMOMYCES LANUGINOSUS EREDETÜ FITÁZ ENZIM JELLEMZÉSE ...................................... 72

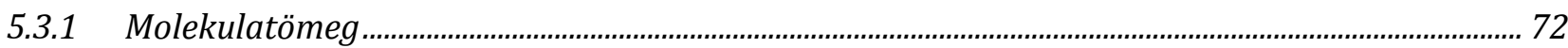

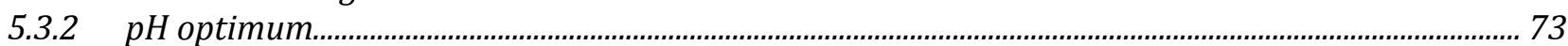

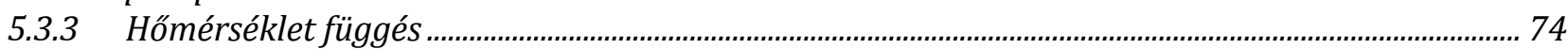

5.3.4 Enzimkinetikai vizsgálatok eredményei ….......................................................................................... 75

5.3.5 Stabilitási vizsgálatok ................................................................................................................................... 76

5.3.6 Fémionok hatása az enzimaktivitásra ………........................................................................................ 78

$5.4 \quad$ MEZOFIL ASPERGILLUS EREDETÜ FITÁZ ENZIM FERMENTÁCIÓ.................................................................... 80

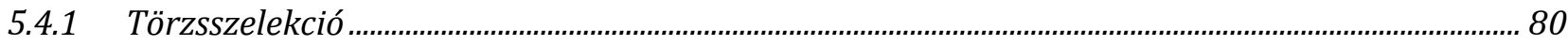

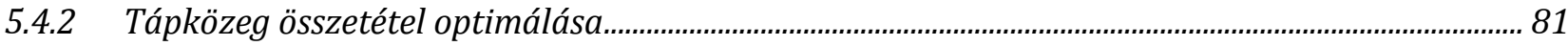

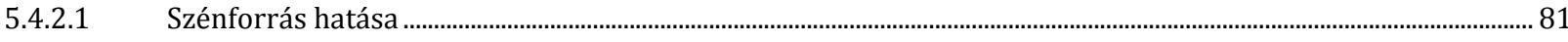

5.4.2.2 Nitrogén forrás hatása ...................................................................................................................................................................... 83

5.4.2.3 A szén- és nitrogénforrások optimális koncentrációjának meghatározása .......................................................................... 84

5.4.2.4 Tápközeg pH-ja.................................................................................................................................................................................... 86

5.4.2.5 Az optimális inokulum mennyiség és tápközeg térfogat meghatározása ........................................................................ 88

5.4.2.6 Felületaktív anyagok hatása................................................................................................................................................ 89

$5.5 \quad$ ASPERGILLUS NIGER EREDETÜ FITÁZ ENZIM TISZTÍTÁSA........................................................................... 91

5.6 ASPERGILLUS NIGER EREDETÜ FITÁZ ENZIM JELLEMZÉSE ....................................................................... 96

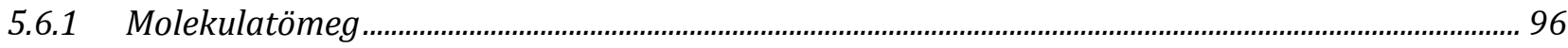

5.6.2 pH optimum

5.6.3 Hőmérséklet függés .................................................................................................................................. 97

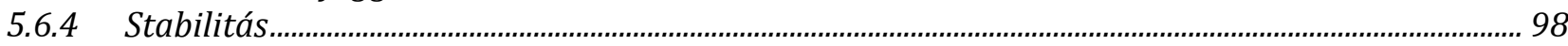

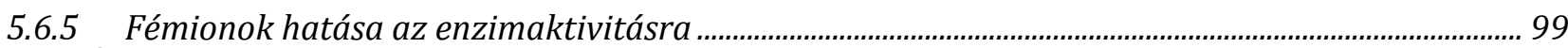

5.7 ÚJ TUDOMÁNYOS EREDMÉNYEK.............................................................................................................

6. KÖVETKEZTETÉSEK ÉS JAVASLATOK

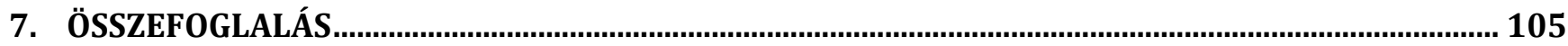

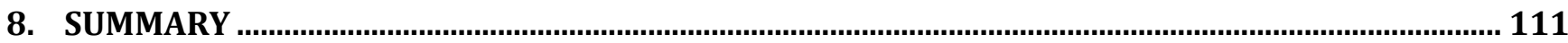

MELLÉKLETEK

M1. FELHASZNÁLT IRODALOM 


\section{JELÖLÉSEK ÉS RÖVIDÍTÉSEK JEGYZÉKE}

Jelölés

ADP
AMP
APS
ATP
BPP
BSA (Bovine Serum Albumin)
CP
CSL
$\mathrm{HAP}^{\text {HAP }}$
$\mathrm{IP}_{2}$
$\mathrm{IP}_{3}$ vagy Ins $(1,2,6) \mathrm{P}_{3}$
$\mathrm{IP}_{4}$ vagy Ins $(1,2,5,6) \mathrm{P}_{4}$
$\mathrm{IP}_{5}$ vagy Ins $(1,2,4,5,6) \mathrm{P}_{5}$
$\mathrm{IP}_{6}$
NADH
PAGE $_{2}$
PAP
PEP
SDS
TEMED
U

Magyarázat

adenozin-difoszfát

adenozin-monofoszfát

ammónium-perszulfát

adenozin-trifoszfát

$\beta$-propeller fitázok

marhaszérum albumin

cisztein foszfatázok

corn steep liquor

hisztidinsavas foszfatázok

mioinozit-dioszfát

mioinozit-trifoszfát

mioinozit-tetrafoszfát

mioinozit-pentafoszfát

mioinozit-6-foszfát, fitinsav

nikotinamid-adenin-dinukleotid

poli-akrilamid gélelektroforézis

bíbor savas foszfatázok

foszfo-enolpiruvát

Na-dodecil-szulfát

$\mathrm{N}, \mathrm{N}, \mathrm{N}, \mathrm{N}$ '-tetrametil-etilén diamin

Unit, nemzetközi egység 



\section{BEVEZETÉS}

A foszfor minden élő szervezet számára nélkülözhetetlen. Építőköve a nukleinsavaknak, ATP-nak, foszfolipideknek és fontos szerepet játszik a mind az állati, mind az emberi szervezet csontosodási folyamataiban, de hatással van a növekedésre, a csont, illetve baromfiaknál a csőr állapotára és a tojás minőségére. A növények fontos foszfor raktározó vegyülete a fitát, elsősorban gabonák, hüvelyesek és olajos magvak tartalmazzák. A fitinsav és sói antinutritív jellegü vegyületek, komplexet képezve a kétvegyértékü kationokkal meggátolják a szervezet számára nélkülözhetetlen ásványi anyagok felszívódását és hasznosulását. Ezen túlmenően a fitátok csökkentik a fehérjék, a keményítő és a lipidek emészthetőségét is, továbbá gátolják bizonyos enzimek, különösen az emésztő enzimek, működését.

A fitinsav különböző mennyiségben található meg a növényi nyersanyagokban, mely a takarmányok alapjául szolgál. A növényi eredetü takarmányokban a foszfor 60-90\%-ban fitát formájában van jelen, ami nehezen hozzáférhető az egygyomrú állatok számára, mivel bélrendszerükből - az emberhez hasonlóan - hiányzik vagy csekély mértékben van jelen a fitinsav bontását végző fitáz enzim. A megfelelő foszforellátás érdekében ezért a takarmányokhoz szervetlen foszfort adagolnak, mely szintén nem hasznosul elégséges mértékben és megnövekedett foszforürítést eredményez. Mindezen tényezők miatt az intenzív állattenyésztés a környezet megnövekedett foszfor terheléséhez vezet, mely a vizek eutrofizációját is okozza.

A fejlődő országokban, ahol a gabona és a hüvelyesek alkotják a táplálék jelentős részét, a fitátok gátolják az ásványi anyagok felszívódását. A fitinsav eltávolítható fizikai (áztatás, főzés) és kémiai (ioncsere, savas hidrolízis) úton is, de a fitinav tartalom csökkentésére az élelmiszerekben és takarmányokban a fitáz enzimmel történő hidrolízis szolgálhat megoldásként. Az enzim segítségével csökkenthető az ásványi anyag hiányból adódó betegségek kialakulásának kockázata azon célcsoportok esetében is, - vegetáriánusok illetve a fejlődő országok lakói - akiknél, az átlagosnál nagyobb a fitát tartalmú növények fogyasztása. Az enzimes techológiák további előnye, hogy kíméletes körülmények között, a környezetterhelés minimálásával, az adott reakcióra specifikusan valósíthatók meg a folyamatok.

A fitáz már világszerte elfogadott és alkalmazott enzim az állatok takarmányozása során. Az ipari enzimek alkalmazási területeik alapján csoportosíthatók: biológiai és gyógyszeripari, élelmiszeripari, valamint az állati takarmányozás területén alkalmazott enzimekre. Az ipari enzimek összesített éves átlagos növekedési üteme 4\%-os, melyek közül a legnagyobb a növekedési ráta a takarmányiparban. Az értékesítésben tapasztalt növekvő tendencia egyik fő oka a fitáz enzim egyre elterjedtebb felhasználása, ennek eredményeként a növekedés a 6\%-ot is elérte 2007-2012 
időszakban. A teljes baromfi és sertés takarmánynak 8\%-a tartalmaz már fitázt. A fitáz környezetvédelemben betöltött szerepe csak növeli jelentőségét.

Újabban felismerték, hogy a fitinsav részleges hidrolízisével olyan meghatározott összetételü egészségmegőrző hatással rendelkező mioinozit-foszfátok állíthatók elő, melyek funkcionális élelmiszer-összetevőként alkalmazhatók. Ezen vegyületek csökkentik a bélrák kockázatát, a szérum koleszterin szintet és a triglicerid szintet kísérleti állatokban, valamint szerepet játszanak a lipid peroxidáció csökkentésében és antioxidáns hatásuk is jelentős. A mioinozit-foszfátok létrehozása kizárólag enzimes technológiával valósítható meg. Az alkalmazott fitáz enzim hatásmechanizmusa, optimális müködési körülményei, szubsztrátspecifitása függ a termelő mikroorganizmustól. A fonalas gombák alkalmazhatósága a biotechnológiai eljárásokban széleskörü, ugyanis számos elsődleges és másodlagos metabolit termék képzésére alkalmasak, mint enzimek, szerves savak, antibiotikumok. A fitáz enzim hatékony alkalmazhatóságának feltétele, hogy ellenálljon az emésztőrendszer és a gyomor savas pH-jának továbbá a fehérjebontó enzimeknek, - azaz megfelelően bontsa a fitinsavat a bélben -, stabil legyen és ellenálló a hőkezelésből adódó károsodásoknak a takarmány előállítása és tárolása során, valamint magas kihozatallal és tisztasággal, olcsón előállítható legyen. Mindezen célok elérése érdekében mezofil és termofil fonalas gomba fajokat választottam kutatásaim tárgyául, melyek nem patogének, nem termelnek toxinokat, általánosan biztonságosnak tekinthetők, így az általuk termelt fitáz enzim is mind élelmiszeripari, mind takarmányozási célokra felhasználható. A különböző eredetű fitáz enzimek elöállítása, tisztítása, jellemzése és alkalmazhatóságuk tükrében tulajdonságaik összehasonlítása voltak legfőbb célkitűzéseim. 


\section{IRODALMI ÁTTEKINTÉS}

\subsection{A fonalas gombák jelentősége és jellemzése}

A számos, nem patogén mikroorganizmus közül, a fonalas gombák kiemelt szerepet töltenek be könnyü tenyésztésük, valamint nagy jelentőséggel bíró metabolitjaik és extracelluláris ipari enzimek előállítása területén. Egyes biotechnológiai-, és ipari folyamatokban jelenleg is számos általuk termelt enzimet hasznosítanak, pl. a keményítő, üdítők, élelmiszerek, textíliák, takarmányok előállítása során, a papír-, bőr-, és sütőiparban, valamint kémiai és orvosbiológiai területeken (BENNET 1998). Számos fermentált élelmiszer és ital készül fonalas gombák felhasználásával, különösen Ázsiában. Leggyakrabban az Aspergillus nemzetséget alkamazzák (pl. A. oryzae, koji), de a Mucor (M. rouxii, Chinese rice) és a Rhizopus (R. oligosporus, tempeh) törzsek is elterjedtek. Különféle metabolitokat képeznek, közöttük antibiotikus (cefalosporin, penicillin) illetve rákmegelőző hatással rendelkezőket is találtak. Termelnek gombaellenes griseofulvint, anyarozs alkaloidákat és növényi növekedési hormonokat (gibberellinek). Ezenkívül vitaminokat, poliszacharidokat és szerves savakat is kiválasztanak, valamint a szerves hulladékok hasznosítására alkalmazható különféle enzimeket szintetizálnak (HAWKSWORTH et al. 1988).

A fonalas gombák olyan kedvező tulajdonságokkal rendelkeznek, mely egyszerübbé teszi fermentációs előállításukat pl. alacsony pH-n és magas só koncentrációnál is szaporodnak, szubsztrátként hasznosítják mind az öt, mind a hat szénatomos cukrokat. A komplex szerves anyagok összetett enzimrendszerük segítségével felvehető tápkomponensekké bomlanak (MAHESHWARI et al. 2000). A különféle korhadt növényi anyagok, mezőgazdasági és ipari melléktermékek olyan szerves-, és ásványi anyagokat tartalmaznak, amelyek hasznosíthatók növekedésükhöz. A bioremediációs folyamatok során a szerves anyagokat humusszá és széndioxiddá alakítják, miközben hő szabadul fel. A komposztálás kevert mikroba populáció tevékenységének köszönhető. Optimális körülmények között 3 szakasza van: az elsőben a mezofil baktériumok vannak túlsúlyban, majd a hőmérséklet emelkedésével a termofil baktériumok veszik át a helyüket, s megjelennek a termofil gombák is. Ez a szakasz néhány naptól, néhány hónapig tarthat. A mikrobák aktivitása hirtelen lecsökken, amikor a hőmérséklet meghaladja a $60^{\circ} \mathrm{C}$-ot, majd a hülés és az érés során, mely szintén hónapokig eltarthat, megjelennek az Aspergillus törzsek és a Thermomyces lanuginosus (TUOMELA 2000). E fonalas gombáknál az ivaros szaporodási forma nem ismert, általában ivartalanul képződő szaporítóképletekkel (konídiumok) szaporodnak. Egyedi és komplex növekedési morfológiát mutatnak függetlenül attól, hogy enzimet, szerves savat vagy antibiotikumot termelnek. 
Az Aspergillus niger és a Thermomyces lanuginosus rendszertani besorolása, valamint az egyes törzsekre jellemző szaporítóképletek az 1. táblázatban láthatók. Az egyes gombafajok bemutatásával külön fejezetben foglalkozom.

1. táblázat: Az Aspergillus niger és a Thermomyces lanuginosus rendszertani besorolása

\begin{tabular}{|c|c|c|}
\hline & \multicolumn{2}{|l|}{ Thermomyces lanuginosus } \\
\hline Birodalom & \multicolumn{2}{|c|}{ Eukaryota } \\
\hline Ország & \multicolumn{2}{|c|}{ Fungi } \\
\hline Tagozat & Eumycota & Ascomycota \\
\hline Altagozat & Deuteromycota & Pezizomycotina \\
\hline Osztály & Hyphomycetes & Eurotiomycetes \\
\hline Nemzetség & Thermomyces & Aspergillus \\
\hline Faj & Thermomyces lanuginosus & Aspergillus niger \\
\hline Konídiumok & 9eshe 20 & \\
\hline
\end{tabular}

\subsubsection{Az Aspergillus niger jellemzése}

Az Aspergillus fajok az egész világon elterjedtek, a melegebb országokban nagyobb számban fordulnak elő. Megtaláljuk őket talajban, lebomló növényi anyagokon és állati maradványokon. Az A. niger szaprofitaként, aerob környezetben növekedve sürü fehér, egyes törzseken világossárgán színezett, vattaszerü micéliumtömeget hoz létre szerves anyagon, melynek elöregedésével fekete színủ konídiumok jelennek meg a micéliumon. A konídiumcsírázás általában gyors folyamat, rövid adaptációs idő után indul be kedvezö körülmények között. A konídiumok gömbölyüek, barnák, eleinte simák, később vastag falúak, sötétek, szemölcsökkel, tüskékkel vagy érdes sávokkal az egész felületen, 4-5 $\mu \mathrm{m}$ nagyok (FASSATIOVA 1984). Az A. niger a mezofil gombák közé tartozik, mivel optimális szaporodási hőmérséklete $35-37^{\circ} \mathrm{C}$, de széles hőmérséklet $\left(6-47^{\circ} \mathrm{C}\right)$ és $\mathrm{pH}$ tartományban $(1,4-9,8)$ is növekedik (SCHUSTER et al. 2002).

Az Aspergillus nemzetség számos alkalmazása ismert a biotechnológiai iparban. Több faja képez szerves savakat (galluszsavat, citromsavat, fumársavat, glukonsavat, oxálsavat) mások extracelluláris enzimeket és zsírokat termelnek. Az A. niger segítségével citromsav és glukonsav állítható elő (NIELSEN et al. 2009). Az Aspergillus niger általánosan biztonságosnak tekintett, GRAS (Generally Recognised As Safe) státusszal rendelkező mikroorganizmus, ami garantálja a gomba, valamint enzimeinek megbízható élelmiszer- és takarmányipari felhasználását. Az Aspergillus bizonyos fajai humán potenciális opportunista kórokozóként mikózis okozói is 
lehetnek. Néhány faj az emberre és állatokra is veszélyes mikotoxinokat (aflatoxin, ochratoxin) termel, amely elsősorban a fertőzött gabonaféléknél jelentkezhet problémaként. Az Aspergillus niger által szintetizált enzimek többek közt: a glükoamiláz (SVENSSON et al. 1986), a pektináz (FAWOLE \& ODUNFA 2003), a celluláz (OKADA 1988), a glükóz-oxidáz (KONA et al. 2001), a kataláz (FIEDUREK 2000), az $\alpha$-galaktozidáz (SCIGELOVA \& CROUT 2000), a lipáz (KAMINI et al. 1998), a proteáz (MUKHTAR \& IKRAM-UL-HAQ 2009) és a fitáz (VATS \& BANERJEE 2005).

\subsubsection{A Thermomyces lanuginosus jellemzése}

A Thermomyces lanuginosus az imperfekt gombák közé (Deuteromycetes) tartozik, aleurokonídiumokkal ivartalanul szaporodik. A hifákról derékszögben kiágaznak az 5,5-12 $\mu \mathrm{m}$ átmérőjü konídiumok. Az éretlen konídiumok színtelenek és sima falúak, de az érés során megbarnulnak és az exokonídium megráncosodik. Különbözö táptalajokon növekedése gyors, 2 nap után a telepek fehérek és filcszerüek, 2,5-5 cm átméröjüek, s 1 mm-nél nem magasabbak. A különböző törzsek felületének szerkezete és színe is eltérő, de általában jellemző, hogy a telepek középtől kiindulva fokozatosan szürkévé, zöldesszürkévé változnak, később vörösesbarnává alakulnak, miközben a telepből kidiffundáló anyagoktól a tápagar színe is megváltozik, lilává illetve borszínűvé alakul.

A Thermomyces lanuginosus termofil gomba, melynek optimális szaporodási hőmérséklete 45-50 ${ }^{\circ}$ C. MAHESHWARI és munkatársai (2000) a Thermomyces lanuginosus fajt azon komposztálásban szerepet játszó gombák közé sorolják, melyek nem képesek a cellulóz bontására. A nem cellulolitikus mikroorganizmusok a komposztban kommenzalizmusban élnek cellulózbontó fajokkal (pl. Chaetomium thermophile), így jutva hasznosítható szénforráshoz, valamint bizonyos aminosavakhoz, melyeket nitrogénforrásként hasznosítanak. Folyadékkultúrában a T. lanuginosus az amilolitikus enzimek mellett (NGUYEN et al. 2000), $\alpha$-galaktozidáz (REZESSY-SZABÓ et al. 2007),

ß-galaktozidáz (FISCHER et al. 1995), lipáz (ARIMA et al. 1972), fitáz (GULATI et al. 2007b), xilanáz (SINGH et al. 2003) és proteáz (LI et al. 1997) enzimeket is termelnek. A Thermomyces lanuginosus gomba termofil tulajdonságából adódóan termostabilis enzimeket szintetizálhat, melyek felhasználási előnyei pl. a rövidebb reakció idő, a mikrobiológiai biztonság és a magasabb hőmérsékleten való alkalmazhatóság pl. takarmánygyártás során.

Bár a fonalas gombák közt számos jó enzimtermelő törzs található, azonban korlátozottak az ismeretek az enzimek aktivitására, termeltetésére, tisztítására és biokémiai jellemzésére vonatkozóan, valamint az enzimek termelésének genetikai háttere ma még jórészt feltáratlan. 


\subsection{A foszfor körforgalma}

A foszfor a biogén elemek közé tartozik, vagyis meghatározó szerepet játszik a sejt életfolyamataiban, építököve a nukleinsavaknak, ATP-nak, foszfolipideknek. Az emberi szervezetben nélkülözhetetlen a szervezet csontosodási folyamataiban, továbbá foszforra van szükség a fehérje-, szénhidrát-, és zsíranyagcseréhez, az idegrendszer müködéséhez, a fehérjeszintézishez és az enzimek müködéséhez is. Az anyagcserében szerepet játszó makroerg foszfátkötések kialakulásában is fontos szerepet tölt be, mely az energia megkötésének és átvitelének alapja. A szervezet a szerves és szervetlen eredetủ foszfort egyaránt hasznosítja. A legfontosabb foszfor forrás a tej, a tojás, a hús, a hüvelyesek, valamint a gabonafélék. A szervezetben levő foszfor $85 \%$-a a csontokban, hidroxil-apatit (kalcium-foszfát) formájában halmozódik fel. A növényekben, gabonafélékben a szerves foszfor fitinsav formájában raktározódik (HAJÓS 2008).

A foszfor biogeokémiai körforgása igen lassú, ezért növekedést meghatározó szerepe van mind a talajban, mind a vízi élővilágban (1. ábra). Fő forrásai a bizonyos kőzetek - főleg az apatit tartalmú magmás képződmények, valamint a szilikátok - mállása során létrejövő másodlagos ásványok, Ca-, Al-Fe-foszfátok. A pH függvényében meszes talajokon főleg Ca-foszfátok, míg savasabb kémhatású talajokon Al- és Fe-foszfátok alakulnak ki. E foszfor források nehezen oldhatóak, emiatt nem hasznosítható formában vannak jelen a természetben (SINGH et al. 2006).

A kötött foszfátok oldatba vitelét segíti elő a talaj mikroflórája. Az itt lévő baktériumok a szerves anyagok bontása során képződött salétromsavval, kénsavval segítik oxidálni a kötött foszforvegyületeket. A talajból szervetlen ortofoszfátion $\left(\mathrm{PO}_{4}{ }^{3-}\right)$ formájában vehető fel a növények és a többi mikroorganizmus számára. Mobilitása igen korlátozott, hiszen hamar megkötődik a talajkolloidok felszínén. A foszfor az egyik leggyakoribb limitáló ásványi tápanyag a növények számára, csekély hozzáférhetősége miatt (RUTTENBERG 2001). 


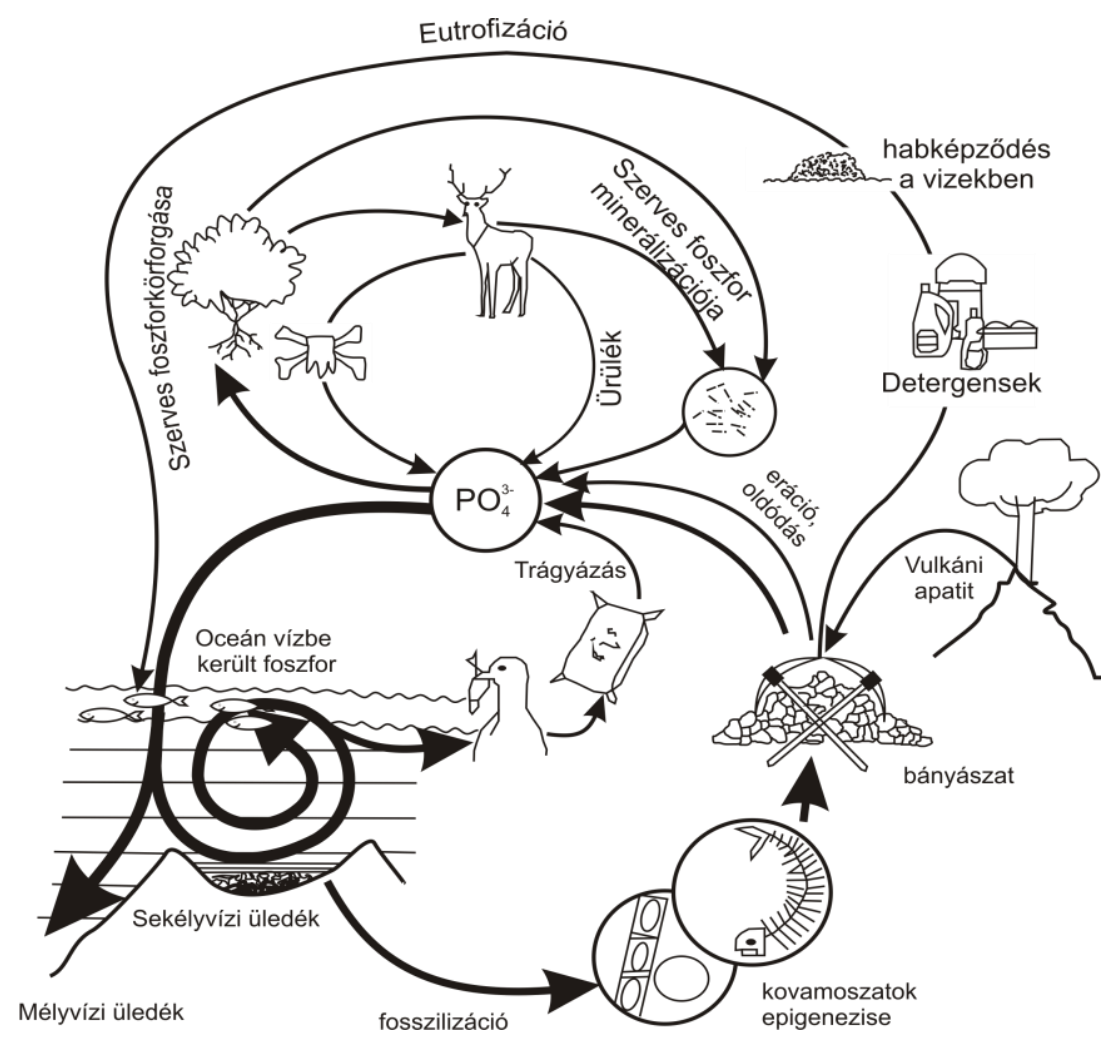

1. ábra A foszfor körforgása (MOSER \& PÁLMAI 1996)

Egyes növények foszfatáz enzimük segítségével is hozzájuthatnak a szükséges foszforhoz. A növénytermesztésben foszfortartalmú mütrágyák alkalmazásával fokozzák a terméshozamot, ám ennek nagy része hasznosítatlanul kimosódik a talajba. Túlzott jelenléte akár káros is lehet, mivel a növényzet túlburjánzásához és a vizek jelentős eutrofizálódásához vezet.

A vízi ökoszisztémák a foszfor nagy részét kívülről, a szárazföldről kapják bemosódás révén. A vízben lévő ortofoszfátokat elsőként a fitoplanktonok veszik fel, amelyek többnyire algák. A táplálékláncban az állatok közé tartozó zooplanktonok, majd pedig a halak következnek. A hal kimondottan fontos foszfor forrás az ember számára. Az állatok a foszforhoz részben a foszfortartalmú vízből, részben a növényi táplálékból jutnak. A növényekben a fitinsav szolgál foszforraktározó vegyületként. A természetes körforgalomban a foszfor jelenlétét a szerves anyagok lebomlása biztosítja. Az élő szervezetek pusztulásával a foszfor visszakerül az élettelen környezetbe, ahonnan a növények, és a vízbe jutva, vagy magával a növényi táplálékkal az állatok ismét egy új ciklusban hasznosítják (FEKETE 2006).

\subsection{A fitinsav}

A fitinsav (mioinozit-1,2,3,4,5,6-hexakisz-dihidrogén-foszfát) a növények szerves foszfor tartaléka, hidrolízise során szervetlen foszfát és mioinozit képződik, továbbá különböző foszforiláltságú köztes termékek is keletkezhetnek, úgymint mioinozit-penta ( $\left.\mathrm{IP}_{5}\right)$, -tetra ( $\left.\mathrm{IP}_{4}\right)$, -tri $\left(\mathrm{IP}_{3}\right)$, -di $\left(\mathrm{IP}_{2}\right)$, és monofoszfát. A fitinsav sói a fitátok, a Ca és $\mathrm{Mg}$ sóját pedig fitinnek nevezik. 
Ezek az anyagok az érés során, a magban halmozódnak fel és raktározói mind a foszfornak, mind az inozitnak.
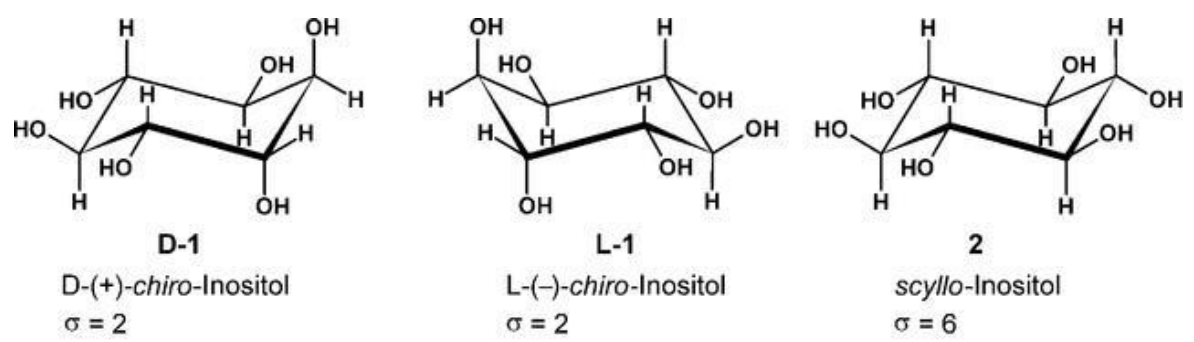

L-1

L-(-)-chiro-Inositol $\sigma=2$

2

scyllo-Inositol $\sigma=6$
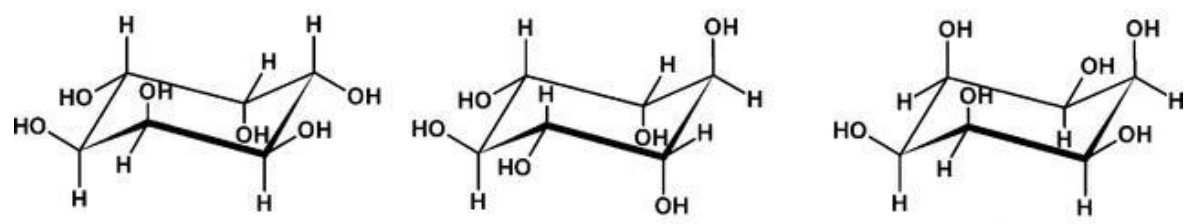

3

neo-Inositol

$\sigma=2$

muco-Inositol

$\sigma=1$

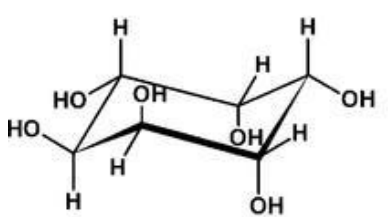

6

allo-Inositol
$\sigma=1$

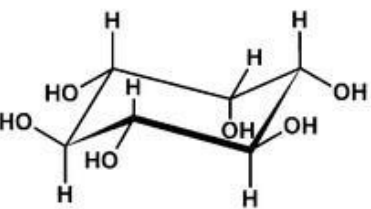

7

myo-Inositol
$\sigma=1$
5

cis-Inositol

$\sigma=3$

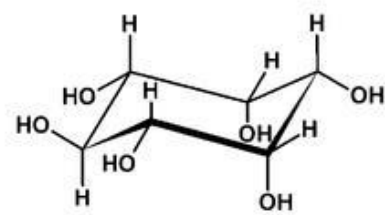

8

epi-Inositol $\sigma=1$

\section{2. ábra: Az inozit sztereoizomerjei (BEKÖ et al. 2014)}

Az inozitnak különböző izomer formái ismertek. A mioinozit gyürühöz kapcsolódó foszfor csoportok száma 1 és 6 között változik. A hidroxil csoportok gyürübeli konformációjának megfelelően 9 féle sztereoizomerről beszélhetünk (2. ábra). Izomerjei közül a mioinozithexakiszfoszfát a leginkább elterjedt forma a természetben, de neo-, scyllo-, D-chiro-inozit-foszfát szintén jelen van a szárazföldi és vízi környezetben.

\subsubsection{Előfordulás}

A fitinsav a növények fontos foszfor raktározó vegyülete, mely elsősorban hüvelyesekben, gabonákban, olajos magvakban, pollenekben és diófélékben halmozódik fel. A szárazanyagnak kb. 1-7\%-át teszi ki. A teljes foszfor tartalom a magvakban általában 60-90\%-ban, a gumósokban 10-25\%-ban fitin foszforként van jelen (LOEWUS 2002), de elöfordul gyümölcsökben, zöldségekben is különböző mennyiségben. A leveles zöldségek igen kis mennyiségben tartalmaznak fitátot. Az érés során a fitát elsősorban a fehérjében gazdag aleuron rétegben és a magbelsőben található az egysziküeknél, azaz a gabonákban, míg a hüvelyesekben és olajos magvakban, illetve a többi kétszikü esetén a fehérje testek globoid kristályaiban raktározódik. A kukoricában ezzel szemben a csírában halmozódik fel (ROOPESH et al. 2006, PLAAMI 1997). Nagy jelentősége van a csíranövény foszfor ellátásában, energia hordozóként is szerepet játszik, 
valamint mobilizálható tápanyagforrást jelent a magvak csírázása idején (BARNA 2000). A fitinsav a növényben lévő fitáz aktivitás révén hidrolizálódik, és foszfát szabadul fel, mely ATP szintézisre fordítódik. A hidrolízis $\mathrm{Ca}^{2+}, \mathrm{Mg}^{2+}, \mathrm{K}^{+}$ionokat is szolgáltat a csíranövénynek, míg gyökeret nem ereszt és képes a talajból a tápanyag felvételére. A növényekben található fitinsav fiziológiai szerepe az érés közbeni gyors fitin bioszintézis, mely során az ATP-t helyettesíti abban az esetben, mikor a mag anyagcseréje gátlódik és nyugalmi állapotban van, továbbá a mag szervetlen foszfát szintjének szabályozója. A mioinozit alacsonyabb foszfor észterei szabadon fordulnak elő a természetben, kis részük a biokémiai reakciókban jelenik meg, mint átmeneti köztes termék, pl. a sejten belüli jelátvitelben, a növényekben és az emberekben egyaránt (BERRIDGE \& IRVINE 1989, WODZINSKI \& ULLAH 1996).

A fitinsav különböző mennyiségben található meg a növényi nyersanyagokban, mely a takarmányok alapjául szolgál. A takarmányokban általában az összfoszfor tartalom 1/3 része emészthető szervetlen foszfor, $2 / 3$ része pedig szerves foszfát formájában van jelen. Baromfi esetén a takarmányösszetevők teljes foszfor és fitát-foszfor tartalmát mutatja a 2. táblázat.

2. táblázat Baromfi takarmány összetevők teljes foszfor és fitát-foszfor tartalma (VOHRA \& SATYANARAYANA, 2003 nyomán)

\begin{tabular}{|l|c|c|c|}
\hline $\begin{array}{c}\text { Takarmány } \\
\text { összetevők }\end{array}$ & $\begin{array}{c}\text { Összes foszfor } \\
\text { tartalom } \\
(\boldsymbol{\%})\end{array}$ & $\begin{array}{c}\text { Fitát-foszfor } \\
\text { tartalom } \\
(\boldsymbol{\%})\end{array}$ & $\begin{array}{c}\text { Fitát P/teljes P } \\
\text { aránya } \\
(\boldsymbol{\%})\end{array}$ \\
\hline Kukorica & 0,39 & 0,25 & 64 \\
\hline Rizs & 0,15 & 0,09 & 60 \\
\hline Búza & 0,44 & 0,27 & 61 \\
\hline Cirok & 0,30 & 0,22 & 73 \\
\hline Árpa & 0,33 & 0,20 & 61 \\
\hline Szójaliszt & 0,88 & 0,46 & 64 \\
\hline Gyapotmag liszt & 0,93 & 0,56 & 82 \\
\hline Napraforgómag liszt & 0,90 & 0,786 & 51 \\
\hline
\end{tabular}

A táblázat adatai alapján is jól látható, hogy a takarmány összetevők 60-65\%-ban fitátként, kötött formában tartalmazzák a foszfort, mely problémát okoz a hasznosulás során.

A humán táplálkozásban a növényi tápanyag mennyiségétől, valamint a feldolgozástól függően a táplálékkal bevitt fitátok mennyisége elérheti a napi 4500 mg-ot. Vegetáriánusok esetén, illetve a fejlődő világ lakosainál átlagosan 2000-2600 mg, míg vegyes táplálkozású egyéneknél a napi bevitel 300-1300 mg (KONIETZNY \& GREINER 2003). Az élelmiszerekben a fitinsav különböző mennyiségben van jelen, 0 - 5,5 g/100 g koncentrációig, azonban hasznosíthatóságuk a monogasztrikus állatokéhoz hasonlóan az embernél sem valósul meg, illetve csökkent mértékü. 


\subsubsection{A fitinsav táplálkozásélettani jelentősége}

A fitinsav táplálkozásélettani szerepe kettős: fiziológiai jelentőségén túl, mely többek között a foszfor raktározásában és a csírázáshoz szükséges energia biztosításában nyilvánul meg, antinutritív voltánál fogva befolyásolja a növényekből készült élelmiszerek biofelhasználhatóságát, ezáltal táplálkozásélettani tulajdonságait. Ezen túlmenően a fitinsav részleges hidrolízisével előállított mioinozit-foszfátok egészségmegőrző hatással rendelkeznek.

\subsubsection{Antinutritív jelleg}

Antinutritív vegyületeknek nevezzük azokat a táplálék alkotórészeket, melyeknek nincs tápértéke, zavarják az emészthetőséget, megnehezítik a tápanyagok felszívódását és hasznosulást (GASZTONYI \& LÁSZTITY 1992). Már hosszú idők óta felismerték, hogy az antinutritív anyagokat, melyek a humán, valamint az állati szervezet számára nem kívánatosak, a növény valójában a mikroorganizmusok, rovarok, madarak és egyéb állatok által okozott sérülések kivédésére állítja elő (BARNA 2000). Ezen antinutritív anyagok egyike a fitinsav. A fitinsav 12 értékü sav, 6 erősen savas pK 1,5- 2,0, 2 gyengén savas pK 6 körül, és 4 nagyon gyengén savas pK 9,0 és 11 csoportja van. A fitinsav hat reaktív foszfát csoportja erős kelátképző ágens, amely megköti a táplálkozás élettanilag fontos kétvegyértékü kationokat, pl. $\mathrm{Ca}^{2+}, \mathrm{Mg}^{2+}, \mathrm{Zn}^{2+}, \mathrm{Cu}^{2+}$, $\mathrm{Ni}^{2+}, \mathrm{Mn}^{2+}$ és $\mathrm{Fe}^{2+}$ (ANGEL et al. 2002, SIMPSON \& WISE 1990, KONIETZNY \& GREINER 2003). Ez a kötés a béltraktus pH körülményei közt oldhatatlan sókat eredményez, mely a bélrendszeren könnyen áthalad, kevésbé abszorbeálódik, a tápcsatornában megakadályozza a fémek felszívódását, s előnytelenül befolyásolja a szervezet ionháztartását (CHERYAN 1980). Különböző pH értékeken eltérő a kötés erőssége. Savas pH-n az oldható fitát komplexek affinitása a fém ionokhoz a következő: $\mathrm{Cu}$ (II) $>\mathrm{Zn}$ (II) $\sim \mathrm{Cd}^{2+}>\mathrm{Mn}^{2+}>\mathrm{Mg}^{2+}>\mathrm{Co}^{2+}>\mathrm{Ni}^{2+}$ (TURNER et al. 2002). A bélrendszerben előrehaladva a fitin-foszfor molekulák ionizálódnak és komplexeket képeznek. A fitátok csökkentik továbbá a fehérjék, a keményítő és a lipidek emészthetőségét, valamint gátolják bizonyos enzimek müködését (COWIESON et al. 2004). A fitinsav komplex képzése a 3. ábrán látható. 


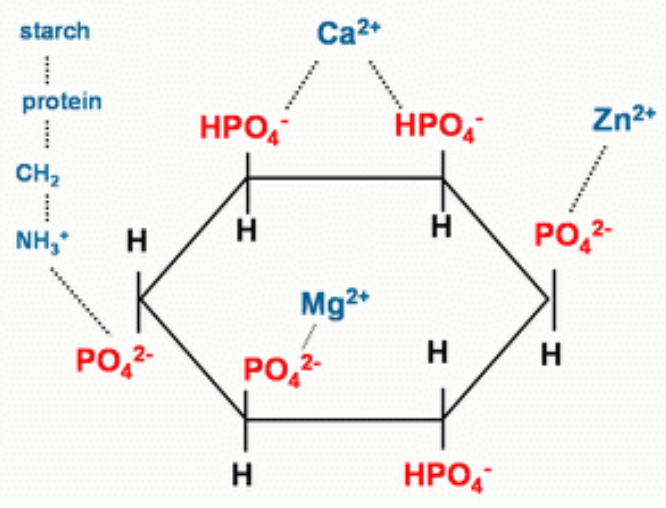

3. ábra A fitinsav komplex képzése

A pH mellett egyéb tényezők is befolyásolják a fitátok komplex képzését, többek között az ionok mérete és vegyértéke, koncentrációjuk és arányuk a fitinsavhoz képest, továbbá az élelmiszer mátrix, amiben jelen vannak (WEAVER \& KANNAN 2002, LOPEZ et al. 2002).

\section{Komplex képzés fémionokkal}

Egy anionos fitát molekula 5 kalciummal képes oldhatatlan kalcium-fitát kötést kialakítani a bélrendszerben, ezáltal az étrendi kalcium kb. egy-harmadát megköti, csökkentve mind a kalcium, mind a foszfor hasznosíthatóságát, de további komplexek létrehozásával gátolódik a vas és a cink felszívódása is. Gyermekeknél a Ca-hiány angolkórt, továbbá csontritkulást okozhat. Búzakorpából készült kenyerek fitát tartalmát csökkentve, a Ca felszívódás mértéke megnövekedett, 36 mg/nap helyett $165 \mathrm{mg} / \mathrm{nap}$ lett emberekben (SELLE et al. 2009).

A fitátok vassal való komplex képzése a világon az egyik legelterjedtebb hiánybetegséghez a vérszegénységhez vezethet, mely a népesség $\mathrm{kb}$. $30 \%$-át érinti. A kialakulásának okai közé tartozhat a nem megfelelő bevitel, illetve pl. terhesség esetén a megnövekedett igény, a csökkent abszorpciós készség, vagy a vérveszteség (LOPEZ et al. 2002). HALLBERG és munkatársai (1987) a vas felszívódás hatását vizsgálva megállapították, hogy már $10 \mathrm{mg}$ fitinsav jelenléte is $55 \%$-os csökkenést okoz a felszívódásban. HURRELL és munkatársai (1992) által végzett kutatások megerősítik ezen eredményeket: azt tapasztalták, hogy szójafehérje izolátumból a fitinsav minimális jelenléte is erősen gátolja a vas felszívódását. PLAAMI (1997) megállapította, hogy csupán a mioinozit-hexa és -pentafoszfát gátolja, csökkenti a vas oldhatóságát, a többi mioinozit-foszfát nem mutat gátlást. Egyéb ásványi anyagok, mint a Ca, a Mg és a Zn, valamint kölcsönhatásaik a Fe-fitát komplexszel, erős hatással vannak a vas oldhatóságára. Különösen a kalcium gátolja a vas felszívódását, oldhatatlan Ca-Fe-fitát komplex kialakítása révén. Ráadásul a vas, cink és kalciumfitát magnéziummal és rézzel is komplexet képez, melyek oldhatóságát a pH is befolyásolja.

A vas hasznosulásának javítása lehetséges a citromsav mennyiségének növelésével. Vegetáriánusok szervezetében vizsgálták a vas mennyiségét, s azt találták, hogy a fitátok által 
okozott vas abszorpciója gátolható C-vitamin, citromsav és egyéb szerves savak alkalmazásával (HARLAND \& MORRIS 1995). Hasonló megállapításra jutottak PABON és LÖNNERDAL (1992) Zn esetében, mivel a szerves savak pl. a citromsav, tejsav, ecetsav oldható ligandumokat képeznek a cinkkel, megelőzve az oldhatatlan fitát-cink komplexek kialakulását. A szerves savak közül a hangyasavval érték el a legjobb eredményeket JONGBLOED és munkatársai (2000). Megállapították továbbá, hogy a mikrobiális fitáz enzim és a hangyasav szinergista hatása eredményezi a Ca és a P legjobb hasznosulását.

\section{Komplex képzés fehérjékkel}

A fitát erős komplexet alakíthat ki fehérjékkel is, melyek így ellenállóvá válnak a proteolízissel szemben és csökkentik a tápértéket az egyes élelmiszerekben, vagy a takarmányban. CARNOVALE és munkatársai (1988) in vitro körülmények között vizsgálták a fehérjék emészthetőségét néhány élelmiszerben és élelmiszer-összetevőben és megállapították, hogy már $10 \mathrm{mg}$ fitinsav adagolás is minden esetben negatív hatást gyakorolt a fehérjék emészthetőségére, egy órás szobahőmérsékleten történő inkubálás során.

A fitinsav és a fehérjék közötti kölcsönhatás ionos típusú és erősen $\mathrm{pH}$ függő. $\mathrm{Ha}$ a $\mathrm{pH}$ a fehérje izoelektromos pontjánál alacsonyabb, a fitát foszforsav csoportja a bázikus aminosavak, az arginin, a lizin és a hisztidin kationjával alakít ki ionos kötést, oldhatatlan fehérje-fitát komplexet képezve (DE RHAM \& JOST 1979, KUMAR et al. 2010). Az izoelektromos pont közelében a fehérjék semleges töltésűvé válnak, a fitinsav nem kötődik és oldhatóvá válik. $\mathrm{pH}=6$ és $\mathrm{pH}=8$ közötti értékek esetén a fitinsav nemcsak a fehérjéket köti meg, hanem hármas komplexek is keletkeznek, melyben a fitinsavhoz a fehérje mellett ásványi anyagok is kötődnek (CHERYAN 1980). Kalcium, magnézium és cink kationok jelenlétében a fehérjék negatív töltésü karboxil csoportja és a fitát között jön létre a kapcsolat (ANDERSON 1985). A komplex kialakulása során megváltozik a fehérjék szerkezete, ezáltal csökken az enzimek aktivitása, a fehérjék oldhatósága és emészthetősége. E negatív hatások azonban eltérőek lehetnek a fehérje forrástól függően. A legjelentősebb mértékben az emésztő enzimek gátlódnak, többek között az $\alpha$-amiláz, a lipáz és a proteinázok (pepszin, tripszin, kimotripszin). A gátló hatás növekszik a mio-inoziton lévő foszfor csoportok számával és a koncentrációval (GREINER \& KONIETZNY 2006), valamint a kalciummal való komplex képzés révén is, mely ion elengedhetetlen az $\alpha$-amiláz és a tripszin megfelelő müködéséhez. A fitátok $\alpha$-amiláz gátló hatását bizonyítja az a tény is, hogy a vércukor tartalom alacsony marad fitátban gazdag táplálék esetén. Ezen élelmiszerek fogyasztása, a táplálkozásfüggő cukorbetegség megelőzésében és kezelésében játszhat szerepet (KONIETZNY \& GREINER 2003). A különböző ionok közötti verseny is hatással van a felszívódásra. Ha azok a fém ionok, melyek szerepet játszanak bizonyos enzimek aktiválásában, más fém ionokra cserélődnek, az 
adott enzim müködése gátlódhat is. Pl. karboxipeptidáz enzimet a cink aktiválja. A cink kobaltra cserélhető, mely a peptidáz aktivitás csökkenését okozza (LOPEZ et al. 2002).

\subsubsection{A fitinsav és a mioinozit-foszfátok jótékony hatásai}

A legújabb kutatások és megfigyelések alapján az antinutritív faktorok közül néhánynak a megítélése megváltozott, jelenlétük (kis mennyiségben) az egészségre előnyös hatást gyakorolhat, segíti egyes betegségek megelőzését. Ezek elnevezését az irodalomban sok helyen ezért antinutritív helyett nem-nutritív faktorként használják, hisz annak ellenére, hogy nem rendelkeznek közvetlen táplálkozási értékkel nem mindig károsak, sőt meghatározott körülmények között előnyös lehet az egészségre gyakorolt hatásuk. A növényi élelmiszer alapanyagok nem-nutritív összetevőit a tudományos érdeklődés is új szempontból veszi vizsgálat alá, és az élelmiszertudomány, illetve a takarmányozással foglalkozó tudomány alapvető kérdései közé tartozik (HAJÓS 2008).

A fitinsavról is az utóbbi időben in vitro és in vivo tanulmányok bizonyították, hogy antinutritív tulajdonsága mellett számos pozitív élettani előnyt biztosít. A fitát, a szabad vasat megkötve természetes antioxidánsként szolgál, ezáltal segíthet különböző daganatos megbetegedések megelőzésében, illetve szerepet játszhat a rák elleni védelemben. A fitát vassal való komplex képzése segít csökkenteni a hidroxil gyökök kialakulását a bélben, és a helyspecifikus DNS károsodást (MIDORIKAWA et al. 2001). Ezen túlmenően a hidroxil gyökök képződésének megakadályozásával a lipid peroxidációt is erősen gátolja. A speciális vas-fitát komplexek kialakulása révén 22 vas kelátor közül a fitinsav bizonyult a leghatékonyabb nem toxikus élelmiszer eredetủ antioxidánsnak (GRAF et al. 1984).

Az érelmeszesedés, szívbetegségek, cukorbetegség és a vesekő kialakulásának kockázatát is mérséklik. Szerepe van a keményítő emésztésében, a vércukorszint alakulásában, a vér koleszterinés triglicerid szintjének csökkentésében. Negatív kapcsolat van a fitát bevitel, valamint a gabona és hüvelyes féléket nagy mennyiségben fogyasztó egészséges emberek vércukor szintje között. Karóbab glikémiás indexe megnövekedett, amennyiben lisztjéből eltávolították a fitátot. Az alacsony glikémiás indexü élelmiszerek fogyasztása segít a cukorbetegeknek a vércukorszint szabályozásában. Mivel a fitinsav a kalcium ionnal komplexet képez, mely gátolja az amiláz aktivitását, ezáltal lassul a keményítő lebontása. Bab és búzakeményítő in vitro körülmények közötti emberi nyállal való hidrolízise lelassult Na-fitát adagolása esetén, de az emésztés helyreállt, ha a Na-fitát mellett kalcium kiegészítést alkalmaztak (HARLAND \& MORRIS 1995).

A fitinsav hatékony mind a rák megelőzésében, mind a kialakult betegség kezelése során (SHAMSUDDIN et al. 1997, KUMAR et al. 2010). Hatékonyságuk azonban függ a beviteli forrástól, a rostok fiziológiai jellemzőitől és a fogyasztás mértékétől (HARLAND \& MORRIS 1995, VERGHESE et al. 2006). Emberi fogyasztás esetén a búzakorpa jobban gátolja a rákos sejtek 
növekedését a bélben, mint a kukorica vagy a zabkorpa (REDDY et al. 2000). A vastagbélrák megelőzésére tehát az egyik általánosan alkalmazott módszer a gabona korpák alkalmazása, mely természetes formában tartalmazza a fitinsavat. Egy másik elképzelés szerint tisztított fitinsavat adagolnak 1-2\% mennyiségben rostszegény takarmányhoz vagy az ivóvízbe. Hogy melyik módszer hatékonyabb, további vizsgálatok dönthetik el (JENAB \& THOMPSON 2002). REDDY és munkatársai (2000) tisztázni kívánták, hogy mely speciális búzakorpa frakció pl. a rost, a lipidek, vagy a fitinsav játsza a legfontosabb szerepet a vastagbélrák megelőzésében. Az alkotórészek egyenkénti eltávolítása nem okozott szignifikáns változást a védő hatásban, azonban a fitinsav és az olaj együttes hiánya a búzakorpából, az adenokarcinomák növekedésével járt. Ez arra utal, hogy a vastagbélrák védő hatása a fitinsav és egyéb alkotórészek, mint az olaj együttes hatásából ered. Éppen ezért a nagy rosttartalmú ételek fogyasztása a rákmegelőző hatás szempontjából ezen összetett hatás miatt kedvezőbb lehet, mint a rostszegény, de tisztított fitinsavval kiegészített diéta. A bélben az emésztetlen keményítőből és rostokból rövid szénláncú zsírsavak, pl. vajsav képződik. A vajsav, illetve egyéb szerves savak termelése lassítja a humán kolorektális rák sejtvonalak növekedését, védelmet nyújt a bélrák ellen.

$\mathrm{IP}_{6}$ rákmegelőző hatását in vivo és in vitro körülmények között is bizonyították prosztata (SINGH \& AGARWAL 2005), mell (VUCENIK et al. 1993) és bélrák (SHAMSUDDIN \& ULLAH 1989) esetében. A hasnyálmirigy rák esetében a halálozási arány 98,1 \%, azaz a betegek többsége esetében az orvosi kezelés, a sebészeti beavatkozás vagy a kemoterápia hatástalan maradt. SOMASUNDAR és munkatársai (2005) azonban hasnyálmirigy rák kezelésében 0,5, 1,0, és 5,0 mM koncentrációban alkalmazva a fitinsavat szignifikáns csökkenést tapasztaltak a sejtburjánzásban, melynek mértéke $37,1 \%$ és $91,5 \%$ közötti.

A fitátok szerepe a rák megelőzésben a tanulmányok alapján azonban nem egyértelmü. Különböző elméletek alakultak ki: az egyik megközelítés szerint az IP 6 erős rákmegelőző hatása in vivo és in vitro körülmények között azon a hipotézisen alapul, hogy az exogén $\mathrm{IP}_{6}$ defoszforilálódik $\mathrm{IP}_{1-5}$ vegyületekké. A lebontása során keletkező mioinozit-foszfátok (tri-, tetra-, pentafoszfátok) számos jótékony, egészségmegőrző hatással rendelkeznek (SHAMSUDDIN 1995). A mioinozitfoszfátoknak a sejtfunkciók szabályozásában, a sejten belüli jelátadásban és müködésben, a sejtek szaporodásában és differenciálódásában van szerepük (HAEFNER et al. 2005, TSUI \& YORK 2010, SHEARS 1998). E köztes termékek gátolják a sejtek növekedését. Amellett, hogy csökkentik a sejtburjánzást, elkülönítik a rosszindulatú sejteket, és gyakran visszaállítják az eredeti fenotípust (SHAMSUDDIN et al. 1997). A fitinsav és a mioinozit-foszfátok rákmegelőző mechanizmusának okai az ásványi anyag kötő képesség, a pH csökkentés, a sejtek közötti jelátvitel megszakítása, a sejt ciklus gátlása és a természetes killer sejtek aktivitásának növelése (JENAB \& THOMPSON 2002). Növeli az intracelluláris foszfát mennyiségét, mely fokozza a természetes killer sejtek 
aktivitását és a gazdaszervezet bakteriális killer kapacitását is (EGGLETON et al. 1991). Ez az aktivitás növeli az immunrendszer válaszát a rákkeltő veszélyforrásokkal szemben, és hozzájárulnak a daganatos sejtek elpusztításához (REDDY 1999).

\subsubsection{A fitátok eltávolítási lehetőségei}

Az antinutritív komponenseket tartalmazó élelmiszerek rendszeres fogyasztása, az egyéni érzékenységtől függően, kisebb-nagyobb mértékü egészségkárosodáshoz vezethet: gátolhatják a növekedést, a pajzsmirigy-müködést negatívan befolyásolják, vagy a hasnyálmirigy és a máj bizonyos elváltozását idézik elö. A többszörös mikroelem hiány, különösen a fejlődő világ országaiban akadályozza a gyerekek megfelelő növekedését (PHILLIPPY \& WYATT 2001). A testtömeg növekedésének elmaradása az emésztőenzimek szintéziséhez szükséges aminosavak felhasználásával is összefüggésbe hozható (LIENER 1994). A kellemetlen mellékhatások kiküszöbölése, minimálisra csökkentése végett ezen táplálékok fogyasztása valamilyen módon előkezelt, feldolgozott formában célszerü. Számos élelmiszeripari eljárást és elkészítési módot alkalmaznak, melyek csökkentik a fitát tartalmat. A fitátok hőkezeléssel nem bonthatók le, általában extrakciós müveleteket alkalmaznak eltávolításukra (BARNA 2000). Az egyszerü mechanikai kezelés, mint az őrlés alkalmazható olyan magvak esetében, melyeknél a fitinsav különleges helyeken lokalizálódik. Ellenkező esetben a fitinsavval együtt a többi tápkomponens is eltávolítódik, azaz a művelet nem jelent megoldást a problémára.

A kutatási eredmények azonban egyértelműen alátámasztják, hogy a fitáz enzimmel megvalósított kezelés a leghatékonyabb módja a fitátok által megkötött kétvegyértékü fémionok, keményítő, fehérjék felszabadításának, ezáltal elősegítve a szervezetben történő hasznosulásukat. Az áztatás, csíráztatás, fermentáció során történő fitát csökkenést a magban lévő fitáz enzim eredményezi. A hidrolízis sebessége függ a hőmérséklettől, a pH-tól, az aktivátorok és inhibitorok jelenlététől, melyek a különböző növényekben eltérők (PLAAMI 1997). Az enzimes kezelés indirekt mikroba tevékenységen keresztül vagy hozzáadott exogén fitáz alkalmazásával is megvalósítható, ha biztosítjuk az optimális környezeti paramétereket (CHERYAN 1980).

LARSSON és munkatársai (1997) különböző gabona típusok esetén vizsgálták a vas, valamint a foszfor hasznosulását Aspergillus eredetü fitáz enzim alkalmazása eredményeként. Hozzáadott fitázzal jelentősen megnőtt a vas felszívódása, repcemag esetén $67 \%$, napraforgó magnál 20,1\%, teljes kiőrlésü búzaliszt és fehér búzaliszt esetén 8,6 \% és 51,4\% volt a növekedés a csupán saját fitázt tartalmazó anyagokhoz képest. A foszfor hasznosulását illetően a napraforgó magnál $(66,4 \%)$ és a repcénél $(30,8 \%)$ a legnagyobb mértékü a növekedés a mikrobiális fitáz alkalmazása esetén. Fehér rizs, barna rizs és rizskorpa teljes fitinsav eltávolításának lehetőségei 
közül is a fitáz enzimes kezelés bizonyult a leghatékonyabbnak LIANG és munkatársai (2009) vizsgálatai szerint, amely a $\mathrm{Ca}, \mathrm{Mg}, \mathrm{Zn}$ hasznosulásának növekedését eredményezte.

Az emberi szervezetben a vas felszívódása $14 \%$-ról $26 \%$-ra növekedett, búzakorpával dúsított zsömlék fogyasztása esetén, ha Aspergillus niger eredetű fitáz enzimmel kiegészítették. Az enzim $37^{\circ} \mathrm{C}$-on két $\mathrm{pH}$ optimummal rendelkezett, $\mathrm{pH}=2$ és $\mathrm{pH}=6$ értékeken. Mivel a fitát lebontása jórészt a gyomorban zajlik, a mikrobiális fitáz hatékonyabbnak bizonyult a $\mathrm{pH}=5$ optimummal rendelkező búza fitázánál (SANDBERG et al. 1995). Malacok takarmányozása során A. niger fitáz enzimet $\left(800 \mathrm{U} \mathrm{kg}^{-1}\right)$ alkalmazva a fitát $48 \%$-a lebomlott (MROZ et al. 1994).

Labor kísérletek eredményeként megállapították, hogy 500-1000 U fitáz 1 g szervetlen foszfor kiegészítésnek felel meg, mely 30-50 \%-kal csökkenti a foszfor kibocsátást (LIU et al. 1998, YI et al. 1996). SCHAFER és munkatársai (1995) tapasztalatai, hogy 500U fitáz $1 \mathrm{~kg}$ takarmányhoz adagolva $20 \%$-kal növeli a foszfor hasznosulását és 28\%-kal csökkenti a foszfor kiürülését a természetbe. Tehát a fitáz alkalmazásával nemcsak a szervetlen foszfor adagolás csökkenthető, de malacok takarmányát fitáz enzimmel kiegészítve növekedett a foszfor, kalcium, zink és energia felvétel 35, 38, 25 és 5,5\%-kal, míg a réz és magnézium hasznosíthatósága nem változott (REILLY et al. 2010).

\subsection{A fitáz enzim}

A fitázok a foszfatázok egy speciális csoportja, mely a fitinsav és a fitátok hidrolízisét katalizálja mioinozit foszfát intermediereken keresztül szervetlen foszforrá és inozittá (WYSS et al. 1999a). A fitázt a XX. század első felében fedezték fel, de a 60-as évekig a fitát bontó mikroorganizmusoknak és enzimeinek megismerése, jellemzése iránti igény nem növekedett. A közelmúltban a fitáz enzimmel kapcsolatos kutatások elsősorban a fitát-foszfor hasznosíthatóságának a javításával foglalkoztak, mellyel a monogasztrikus állatok nagyüzemi tenyésztése által okozott túlzott foszfor terhelés csökkenthető. Alkalmazása azonban egyre nagyobb teret hódíthat a humán táplálkozásban, részben a fitinsavhoz kötött táplálkozás-élettanilag nélkülözhetetlen ásványi anyagok felszabadításával, részben a részleges hidrolízissel keletkező speciális mioinozit-foszfátok egészségmegőrzésben kifejtett jótékony hatásával.

A különböző fitáz enzimek izolálhatók növényekből, mikroorganizmusokból, és csoportosíthatók pH optimumuk, katalitikus mechanizmusuk, valamint sztereospecifikusságuk alapján.

\subsubsection{Osztályozás}

Az Elméleti és Alkalmazott Kémia Nemzetközi Egyesület, valamint a Biokémia és Molekuláris Biológia Nemzetközi Egyesület (IUPAC-IUBMB) a fitáz enzimeket három csoportba sorolja. A 
csoportosítást aszerint végzi, hogy az enzim a fitinsav mioinozit gyürüjének melyik foszfát csoportját tekinti elsődleges támadási helyének, valamint, hogy a hasítást követően milyen mioinozit-foszfát intermedierek keletkeznek. Ezek alapján megkülönböztethetők 3-fitázok, 4/6fitázok és 5-fitázok (OH et al. 2004). A pH aktivitásuk alapján két fő csoportra oszthatók a fitázok: savas és lúgos fitázok. A savas fitázok előnye a széles szubsztrát specifitás, melyeket elsősorban a takarmányozásnál alkalmaznak (SINGH et al. 2011).

A foszfor csoportok lehasítása a fitátról az élővilág diverzitása következtében nem egységesen alakult ki. A defoszforilálási folyamatok különbségei alapján a csoportosítást a következőkben mutatom be.

\subsubsection{3-fitázok}

EC 3.1.3.8: 3-fitáz (mioinozit-hexakiszfoszfát-3-foszfohidroláz)

egyéb nevei: fitáz, fitát-3-foszfatáz

Elsődleges támadási helye a szubsztrátum 3-helyzetű észterkötése, mely reakció a következőképp írható le:

Mioinozit-hexafoszfát $+\mathrm{H}_{2} \mathrm{O}=$ D-mioinozit 1,2,4,5,6-pentafoszfát + ortofoszfát

A 3-fitázok képviselik a fitázok legnagyobb csoportját, s általában gombákból és baktériumokból izolálhatók. A legtöbb 3-fitáz szerkezete homológ a $\beta$-propeller- (BPP) és a hisztidinsavas foszfatázokkal (HAP). A $\beta$-propeller foszfatázok szorosan kapcsolódnak $3 \mathrm{Ca}$ ionhoz és 2 szomszédos foszfát csoporthoz, hogy megkötődjenek a hasítási és a szubsztrát felismerő helyen, mielőtt a hidrolízist megkezdik. A katalizált folyamat végterméke a mioinozit-(2,4,6)trifoszfát. A 4. ábrán a fitinsav defoszforilációja látható Saccharomyces cerevisiae eredetű fitázzal.

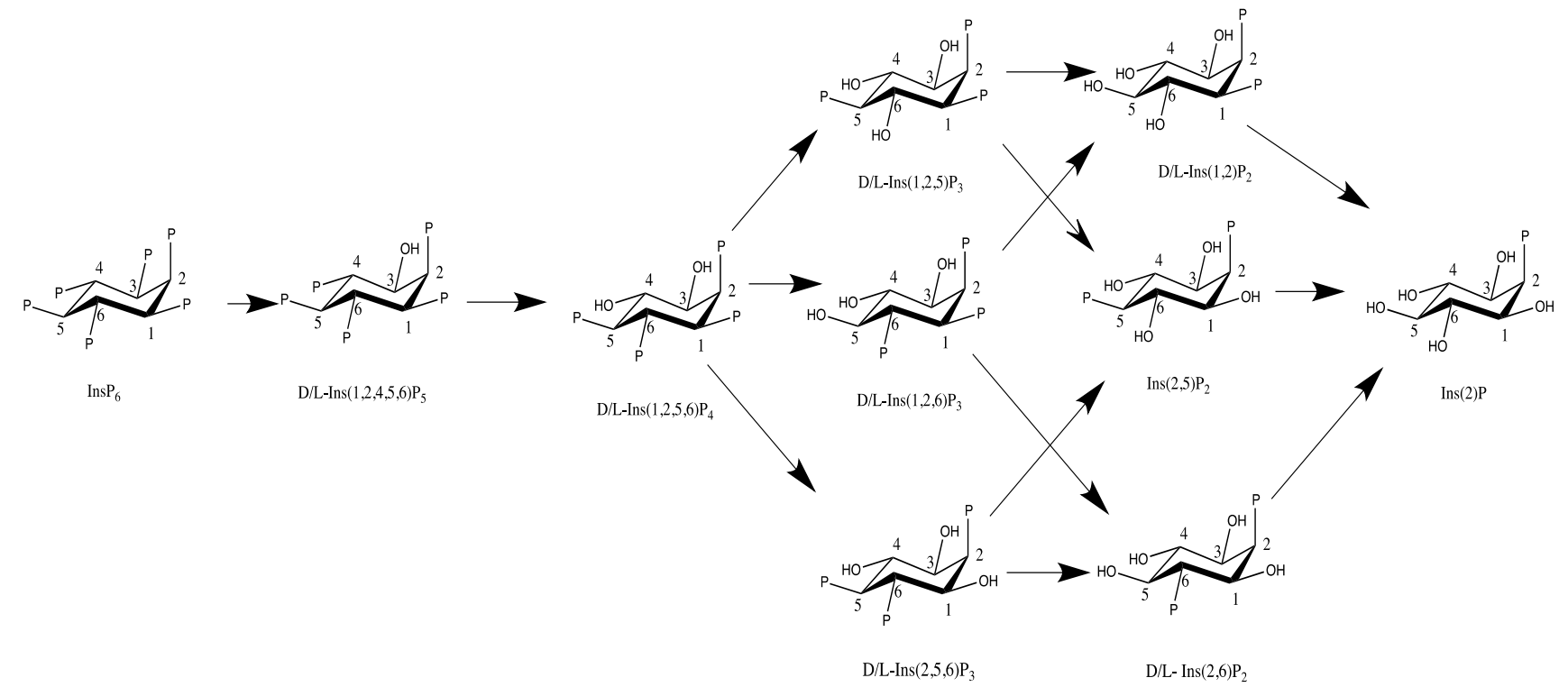

4. ábra A fitinsav defoszforilációja Saccharomyces cerevisiae eredetü fitázzal (BOHN et al. 2008 nyomán) 
A hidrolízis a 3. szénatomon kezdődik, s a lebontási útvonal a következő: Ins( $(1,2,4,5,6) \mathrm{P}_{5}$, $\operatorname{Ins}(1,2,5,6) \mathrm{P}_{4}, \operatorname{Ins}(1,2,6) \mathrm{P}_{3}$ és egyéb mioinozit-trifoszfátok, majd végül az $\operatorname{Ins}(2) \mathrm{P}$.

\subsubsection{4/6-fitázok}

EC 3.1.3.26: 6-fitáz (mioinozit-hexakiszfoszfát-6-foszfohidroláz)

egyéb nevei: fitáz, fitát-6-foszfatáz

Elsődleges támadási helye a szubsztrátum 6-helyzetü észterkötése, mely reakció a következőképp írható le:

Mioinozit-hexafoszfát $+\mathrm{H}_{2} \mathrm{O}=$ D-mioinozit 1,2,3,4,5-pentafoszfát + ortofoszfát

A 4/6-fitázok a mioinozit gyürü 4. vagy 6. szénatomhoz kapcsolódó foszfátcsoportot hasítják le először (5. ábra).

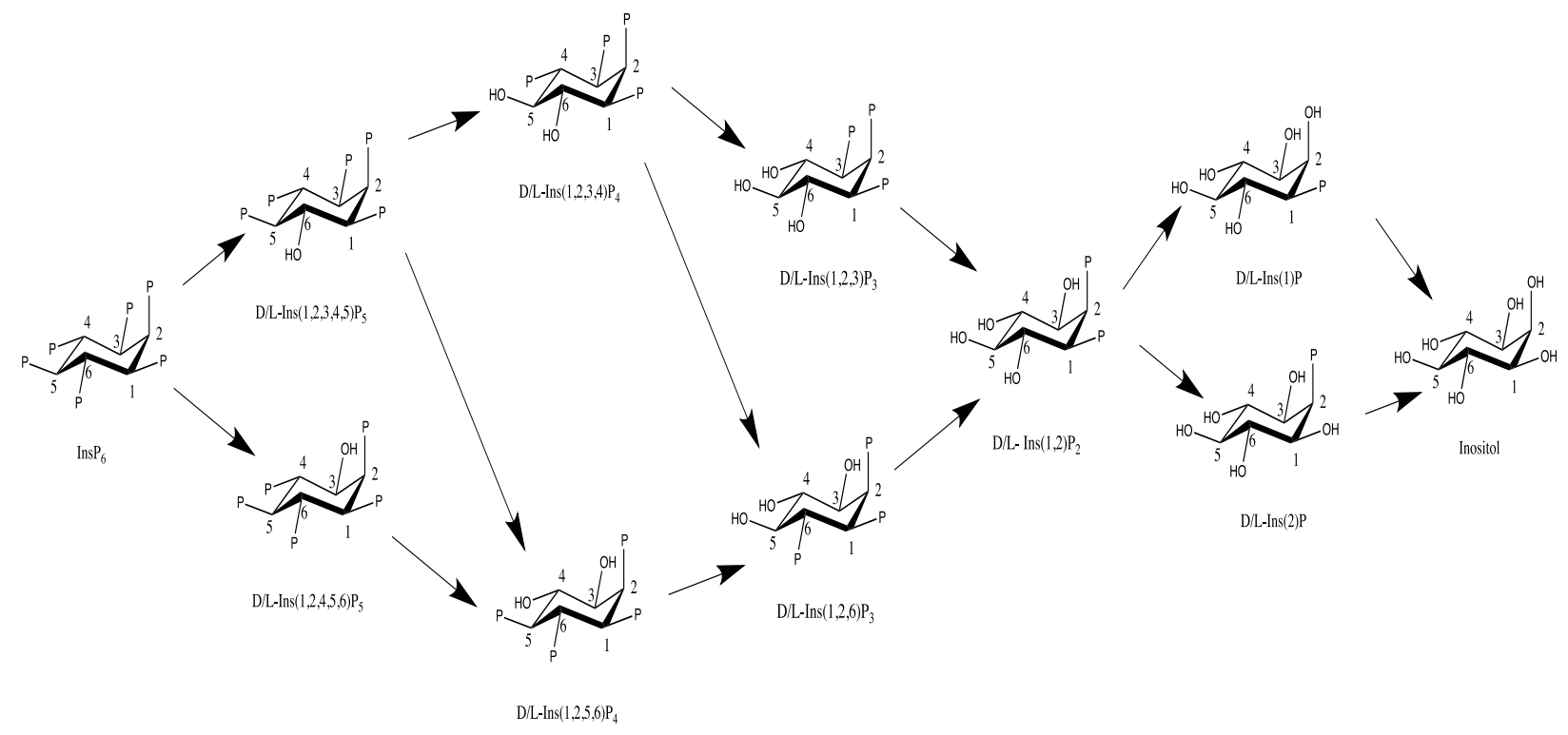

5. ábra A fitinsav defoszforilációja búza eredetü 4/6-fitázzal (BOHN et al. 2008 nyomán)

Számos különböző szerkezetű fitázt sorolnak ide: hisztidinsavas foszfatázokat, $\beta$-propeller foszfatázokat és bíborsav foszfatázokat is. A növényi eredetü fitázok tartoznak ebbe a csoportba. Általában jól müködnek savas környezetben ( $\mathrm{pH}=4-6$ között) és $40-60^{\circ} \mathrm{C}$-on. A fitinsav defoszforilációja látható az 5. ábrán búza eredetü 4/6-fitázzal.

\subsubsection{5-fitázok}

EC 3.1.3.72: 5-fitáz (mioinozit-hexakiszfoszfát-5-foszfohidroláz)

egyéb nevei: fitáz, fitát-5-foszfatáz

Elsődleges támadási helye a szubsztrátum 5-helyzetü észterkötése, mely reakció a következőképp írható le:

Mioinozit-hexafoszfát $+\mathrm{H}_{2} \mathrm{O}=$ D-mioinozit 1,2,3,4,6-pentafoszfát + ortofoszfát 
Csupán néhány 5-fitázról olvashatunk a szakirodalomban, közülük egyet a liliom pollenjéből izoláltak. Az enzim a lúgos fitázok közé tartozik, mivel aktivitása $\mathrm{pH}=8$-as értéken és $55^{\circ} \mathrm{C}$-on a legmagasabb. A foszfát csoport hasítását a mioinozit gyürü szimmetria síkjában kezdi meg. A 6. ábrán a fitinsav defoszforilációja látható liliom eredetű 5-fitázzal.

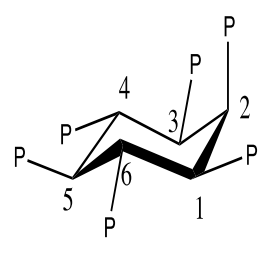

$\operatorname{InsP}_{6}$

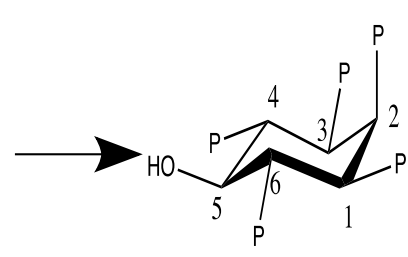

$\operatorname{Ins}(1,2,3,4,6) \mathrm{P}_{5}$

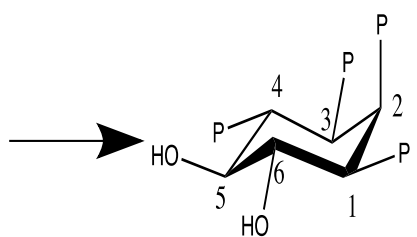

$\mathrm{D} / \mathrm{L}-\operatorname{In}(1,2,3,4) \mathrm{P}_{4}$

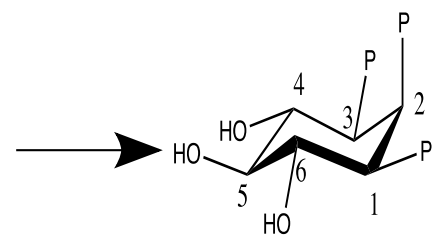

$\operatorname{Ins}(1,2,3) \mathrm{P}_{3}$

6. ábra. A fitinsav defoszforilációja liliom eredetű 5-fitázzal (BOHN et al. 2008 nyomán)

HAROS és munkatársai (2009) kutatásai alapján a Bifidobacterium pseudocatenulatum ATCC 27919 törzs fitáz enzime is az 5-fitázok közé sorolható. A következő lebontási útvonalat határozták meg: $\operatorname{IP}(1,2,3,4,5)$ vagy $\operatorname{IP}(1,2,3,4,6)$ mioinozit-pentafoszfát; $\operatorname{IP}(1,2,3,4)$ mioinozittetrafoszfát, s végül $\operatorname{IP}(1,2,3)$, $\operatorname{IP}(1,2,4)$, és $\operatorname{IP}(1,3,4)$ mioinozit-trifoszfátok keletkeznek. A Bifidobacterium pseudocatenulatum fitátbontó aktivitása pH=6,5-7,0 között maximális.

\subsubsection{Szerkezet}

A különböző mikroorganizmusok által termelt fitázok szerkezetileg nem feltétlenül hasonlóak, az osztályozásuk elsődlegesen katalitikus tulajdonságaik alapján történik. Négy különböző szerkezetű, de azonos aktív centrumú osztályt különböztethetünk meg: hisztidinsavas foszfatázok (HAP), $\beta$-propeller fitázok (BPP), cisztein foszfatázok (CP) és bíbor savas foszfatázok (PAP) (MULLANEY \& ULLAH 2005).

Az enzim jellemzések elsősorban a HAP fitázokra korlátozódnak, ugyanis az enzimaktivitás mérésére, a Na-fitátból, mint szubsztrátumból felszabaduló szervetlen foszfor meghatározása a legelterjedtebb módszer. Ebből következően az ezen az eljáráson alapuló törzsszelekció a HAP fitázok megismerését eredményezi. A hisztidinsavas foszfatázok közé tartozik a legtöbb baktérium, gomba és növényi eredetü fitáz. A HAP osztály minden tagjánál megfigyelhető, hogy az aktív centrum fehérje mintázata az N-terminálisnál RHGXRXP (arginin-hisztidin-glicin-X-arginin-Xprolin, az X helyén bármilyen aminosav állhat) és HD (hisztidin-aszparaginsav) a C-terminálisnál (VAN ETTEN et al. 1991).

A hisztidinsavas foszfatázok széles szubsztrátspecifitással rendelkeznek, de kicsi a specifikus aktivitásuk a fitinsavhoz, hidrolizálják a fémmentes fitátot savas körülmények között, s mioinozitmonofoszfát végtermékig bontanak. Ezzel szemben a lúgos fitázok szük szubsztrát specifitúak, ám a fitinsavhoz nagy specifikus aktivitást mutató enzimek, melyek elsősorban a Ca-fitátot hidrolizálják mioinozit-trifoszfátot eredményezve. A két hisztidinsavas csoport jellemzője (phyA és phyB), hogy 
széles szubsztrátspecifitásúak, s fémmentes fitátokkal lépnek reakcióba savas körülmények között (BOHN et al. 2008). Az A. niger NRRL 3135 fitáz (phyA) nagy specifikus aktivitást mutat fitinsavra (WODZINSKI \& ULLAH 1996), míg ugyanezen törzsből izolált másik fitáz enzim (phyB) (ULLAH \& CUMMINS 1987) eltérő katalitikus tulajdonságokat mutatott.

3. táblázat: A lúgos és hisztidinsavas fitázok összehasonlítása molekuláris és biokémiai tulajdonságai alapján (OH et al. nyomán, 2004)

\begin{tabular}{|c|c|c|c|}
\hline \multirow{2}{*}{ Tulajdonságok } & \multicolumn{2}{|c|}{ Hisztidinsavas fitáz } & \multirow{2}{*}{ Lúgos fitáz } \\
\hline & Phy A & Phy B & \\
\hline Molekulatömeg & $62-128 \mathrm{kDa}$ & $270 \mathrm{kDa}$ & $38-45 \mathrm{kDa}$ \\
\hline Glikoziláltság & igen & igen & nem \\
\hline pH optimum & $2,5-5,0$ & 2,5 & $7,0-8,0$ \\
\hline Hőmérséklet optimum & $55-60^{\circ} \mathrm{C}$ & $55-60^{\circ} \mathrm{C}$ & $55-70{ }^{\circ} \mathrm{C}$ \\
\hline Hőstabilitás & kicsi $\left(60^{\circ} \mathrm{C}\right)$ & kicsi $\left(60^{\circ} \mathrm{C}\right)$ & nagy $\left(85-95^{\circ} \mathrm{C}\right)$ \\
\hline $\mathrm{Ca}^{2+}$ hatása & gátló & gátló & serkentő \\
\hline EDTA hatása & serkentő & serkentő & gátló \\
\hline Szubsztrátspecifitás & széles & széles & specifikus \\
\hline Pozíció specifitás & D-3 helyzetü fitát & D-3 helyzetü fitát & D-3 helyzetü fitát \\
\hline Végtermék & $\mathrm{IP}_{1}+5 \mathrm{P}_{\mathrm{i}}$ & $\mathrm{IP}_{1}+5 \mathrm{P}_{\mathrm{i}}$ & $\mathrm{IP}_{3}+3 \mathrm{P}_{\mathrm{i}}$ \\
\hline Aktív hely & + töltésü aminosav & + töltésü aminosav & - töltésü aminosav \\
\hline Kristály szerkezet & $\begin{array}{l}\text { egy nagy } \alpha / \beta \text { és } \\
\text { egy kis } \alpha \text { domén }\end{array}$ & $\begin{array}{l}\text { egy nagy } \alpha / \beta \text { és egy } \\
\text { kis } \alpha \text { domén }\end{array}$ & $\begin{array}{l}\text { 6-szárnyú } \beta \text { - } \\
\text { propeller }\end{array}$ \\
\hline Aminosavak száma & $465-469$ & $453-479$ & 383 \\
\hline
\end{tabular}

E kétféle hisztidinsavas, valamint a lúgos fitáz molekuláris és biokémiai tulajdonságai közötti különbségeket és hasonlóságukat foglalja össze a 3. táblázat. Látható, hogy $\mathrm{OH}$ és munkatársai (2004) mindkét hisztidinsavas fitáz esetén széles szubsztrátspecifitást állapítottak meg. Az A. niger phyA és phy B enzimei között szerkezetbeli különbségek is mutatkoztak, ugyanis míg a phyA monomer, a phyB tetramer szerkezetü. Az enzim egy nagyobb $\alpha / \beta$-doménből és egy kisebb $\alpha$ doménből áll. A nagyobb domén egy központi hatszálú $\beta$-lemezzel rendelkezik, melyhez négy hosszabb és két rövidebb hélix kapcsolódik. Az $\alpha$-doménnek egy hosszú központi $\alpha$-hélixe van, melyet hét rövidebb hélix vesz körül (MISSET 2003). A hisztidinsavas foszfatáznak van egy harmadik csoportja, melyek a következő néhány jellemzőben térnek el a többi hisztidinsavas fitáztól: nem glikozilált fehérjék, intracellulárisak, kis molekulatömegűek és a bontást a 6-os pozícióban kezdik (OH et al. 2004).

A 7. ábrán két fitáz a Bacillus amyloliquefaciens (A) és az Escherichia coli (B) szubsztrátkötő helyének felülete látható, melyet a felületi feszültség változása alapján színeztek: -7 kt/e a pirostól 7 kt/e a kékig, a fehérjék és nukleinsavak általi elektrosztatikus potenciál grafikus megjelenítésének segítségével (HONIG \& NICHOLLS 1995). A két enzimmodellein láthatók a szubsztrátkötő helyek. Az E. coli fitáz pozitív töltésü aktív centruma a fémmentes fitátokat részesíti 
előnybe, szemben a B. amyloliquefaciens negatív töltésű aktív centrumával, mely kedvező elektrosztatikus környezetet nyújt a pozitív töltésü kalcium-fitát komplexnek.
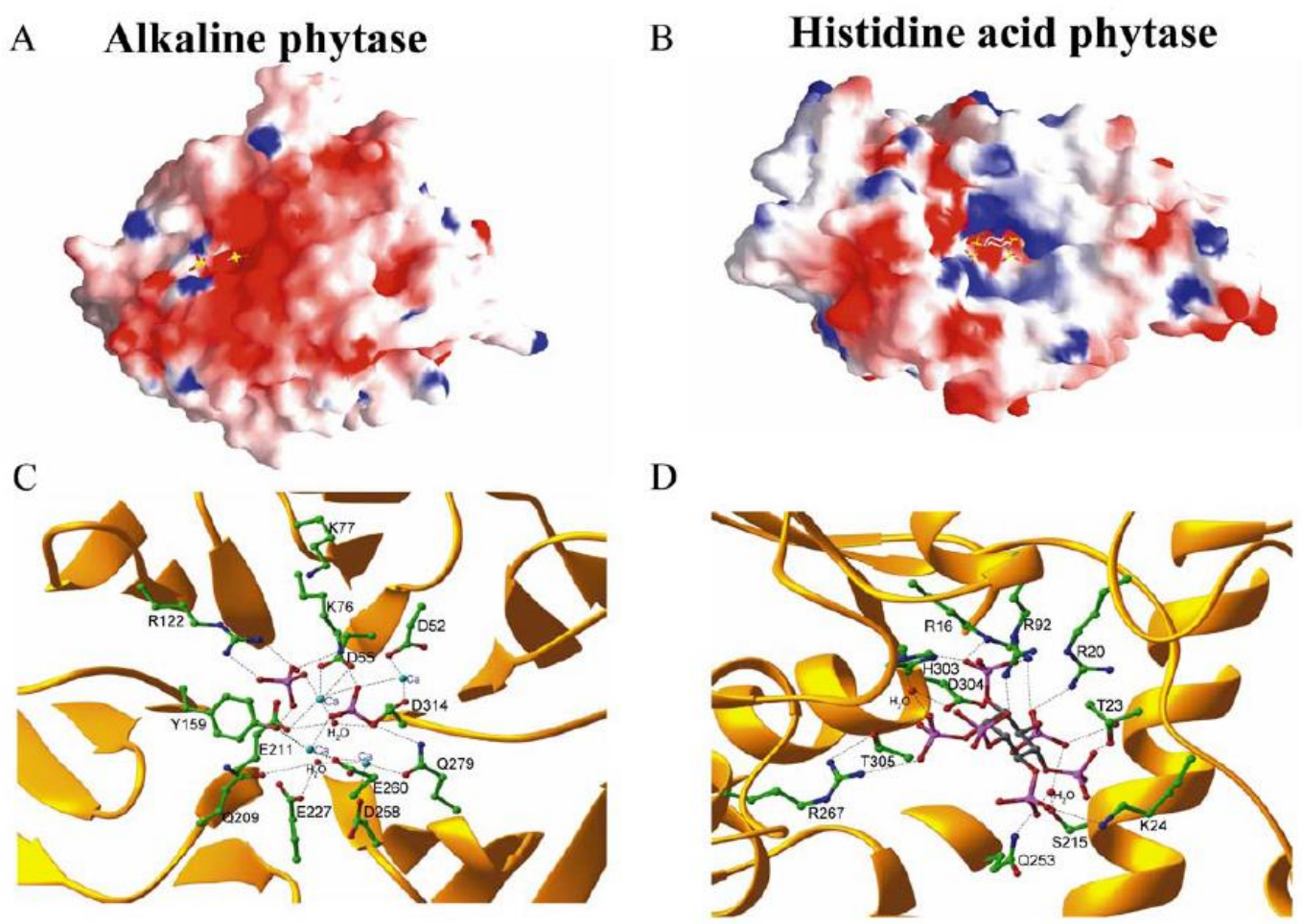

7. ábra A-D. Elektrosztatikus felületi feszültség a Bacillus amyloliquefaciens lúgos

$(A, C)$ és az Escherichia coli HAP $(B, D)$ fitázának aktív centrumában $(\mathrm{OH}$ et al. nyomán, 2004)

$\beta$-propeller fitázt Bacillus subtilis és Bacillus amyloliquefaciens baktériumokból izoláltak. A molekula hatszárnyú propellerhez hasonlít. Az enzim $\mathrm{Ca}^{2+}$ függő, mely a termostabilitást és a katalitikus aktivitást is befolyásolja ( $\mathrm{OH}$ et al. 2001). A bíbor savas foszfatázok metalloenzimek, a bab eredetủ fitáz 3D struktúrájának kialakításában $\mathrm{Fe}^{3+}$ és $\mathrm{Zn}^{2+}$ ionok vesznek részt (KLABUNDE 1994).

A hisztidinsavas foszfatázok szerkezetére jellemző hét aminosavból álló RHGXRXP peptid szekvencia megtalálható mind a termofil, mind a mezofil penészekben, de a bakteriális és a növényi fitázokban nem. A 8. ábrán különböző gomba eredetü fitázok szekvenciájának összehasonlítása látható. A vizsgált gomba törzsek esetén az adott szekvencia - RHGXRXP - első X helyén minden esetben alanin található, míg a második X helyén a Myceliophthora thermophila kivételével (ahol alanin), tirozin helyezkedik el.

A specifikus aktivitás növelése genetikai módosítással is megvalósítható. Ehhez nagyon fontos az aminosavak sorrendjének ismerete. Az A. niger NRRL 3135 fitáz N-terminális része kb. 50 aminosavat tartalmaz, mely a molekula felszínén helyezkedik el. Arg58, Arg62, Arg142, His338, és Asp 339 aminosavak az esszenciális H59 körül helyezkednek el minden gomba eredetű fitáznál. 


AAU93517
XP_001267160
ADP05109
AAB26466
ACE79228
AAB96871
ADI48369
AAB96873
XP_002148821
XP 002849736
AAB 52508

RVTFVQMLSRHGARYPTSSKSKKYKQLVTALQRNATSFKGKFAFLKTYNY RVTFVQVLSRHGARYPTSSKSKKYKKLVTAIQANATSFKGKFAFLKTYNY RVTFAQVLSRHGARYPTDSKGKKYSALIEEIQQNATTFDGKYAFLKTYNY RVTFAQVLSRHGARYPTDSKGKKYSALIEEIQQNATTFDGKYAFLKTYNY RVTFAQVLSRHGARYPTDSKGKKYSALIEEIQQNATTFDGKYAFLKTYNY EVTFVQVLSRHGARYPTESKSKAYSGLIEAIQKNATSFWGQYAFLESYNY ELTFVQVLSRHGARYPTASKSKKYKSLIQAIQANATAYNGQSVFLRAYNY KITFVQLLSRHGARYPTSSKTELYSQLISRIQKTATAYKGYYAFLKDYRY DVTFVQSLTRHGARYPTAKKNTAYKKLIEAIQTNATKLEGKYAFLKTYNY RITFAQSLQRHGARYPTKSKSATYSELIERIQNDATAFKDEFAFLEDYTY EVTFAQVLSRHGARAPTLKRAASYVDLIDRI HHGA ISYGPGYEFLRTYDY

\section{8. ábra Különböző gomba eredetü fitázok aminosav sorrendje}

Hozzáférési szám: AAU93517 A. fumigatus, XP_001267160 Neosartorya fischeri, ADP05109 A. niger, AAB26466 A. ficuum, ACE79228 A. japonicus, AAB96871 E. nidulans, ADI48369 Penicillium oxalicum, AAB96873 Talaromyces dupontii, XP_002148821 Talaromyces marneffei, XP_002849736 Arthroderma otae, AAB52508 Myceliophthora thermophila

Az aktív hely a kapcsolódási felületen, a két domén között egy nagy bemélyedésben található, melyet hátulról az N-terminális vég zár le. Feltételezik, hogy a fitáz szekvenciában a His59 felelős a fitát-foszforral szembeni nukleofil támadásért, az Asp339 vagy His338 pedig a távozó alkoholos hidroxil proton donorja. Az aktív centrumnak egyébként vannak pozitív töltésű részei: Arg58, Arg62 és Arg142, melyek megfelelő környezetet biztosítanak az erősen negatív töltésü fitát megkötéséhez (MISSET, 2003). Az aminosavak a 27. és 28. helyen egy sapkát (cap) képeznek, az aktív hely hátsó részét bezárva. Az Aspergillus fumigatus fitázának 27. aminosava glutamin, mely feltehetőleg részt vesz a szubsztrát megkötésében és az enzim alacsonyabb specifikus aktivitással bír, mint az A. terreus fitáz enzime, melyben ugyanezen a helyen leucin szerepel. Helyspecifikus mutagenezissel az A. fumigatus glutaminját leucinra cserélve a specifikus aktivitás növekszik. Ugyancsak növelhető a specifikus aktivitás - bár kisebb mértékben - ha más alifás aminosavra (alaninra, valinra) cseréljük a glutamint. Bár az A. terreus szük pH tartományban optimális, az aminosav módosítás az A. fumigatus széles $\mathrm{pH}$ optimum tartományát nem befolyásolta (TOMSCHY et al. 2000).

A legtöbb gomba eredetủ fitáz glikozilált formában van jelen, továbbá a génekben gyakran prekurzor fehérjeként vannak kódolva. A glikozilált, érett enzim molekulatömegéhez a glikozil láncok 20-65\%-ban járulnak hozzá (MISSET 2003). A lúgos fitáz nem glikolizált.

6 különböző gomba: Aspergillus niger, Aspergillus terreus, Aspergillus fumigatus, Emericella nidulans, Myceliophthora thermophila és Talaromyces thermophilus fitázát túltermeltették fonalas gombákban és élesztőkben, majd a biofizikai tulajdonságaikat összehasonlították az E. coli fitázával. WYSS és munkatársai (1998) megállapították, hogy a glikolizáltság mértéke mérsékelt volt a fonalas gombák esetén és kiterjedt, mikor élesztőket alkalmaztak alanyként. Úgy találták, hogy a glikolizáltság mértéke nincs hatással a specifikus aktivitásra és a fitáz termostabilitására. Ezzel ellentétesek HAN és LEI (1999) eredményei, akik munkájuk során azt vizsgálták, hogy a 
glikolizáció gátlása esetén az Aspergillus niger eredetű phyA gén képes-e kifejeződni és hatékonyan müködni Pichia pastoris élesztőben. Tapasztalataik szerint a deglikozilálás után a molekulaméret 95-ről 55 kDa-ra módosult, a termostabilitás pedig $34 \%$-kal csökkent. Mindezek alapján megállapították, hogy a glikoziláció elengedhetetlen a fitáz bioszintéziséhez és termostabilitásának megőrzéséhez.

A diszulfid hidak szerepe is meghatározó a fehérjék térbeli szerkezetének rögzítése során, és biztosítja a katalitikus tulajdonságok megfelelő müködését. A 3D modelles szerkezeti elemzések mutatják, hogy a diszulfid kötések lehetővé teszik a távoli régiók aminosav-szekvenciái közötti kapcsolódást, így biztosítva a molekula aktív centrumát és a szubsztrátkötő helyét. Az extracelluláris fehérjéknél, mint a gomba HAP fitázok, szintén szerepet játszanak a denaturáció és a proteolízis megelőzésében (MULLANEY et al. 2010). ULLAH és MULLANEY (1996) Aspergillus ficuum eredetű fitáz enzim diszulfid kötéseinek szerepét vizsgálták. A ciszteinekben jelenlévő tiolok $(10 \mathrm{db}) 5$ diszulfid hidat képeztek. Unfolding-refolding kísérletek során merkaptoetanol jelenlétében és hiányában, különböző pH értékeken, megállapították, hogy a diszulfid hidak jelenléte az aktív központ szerkezetének megtartásában igen fontos. Egyenként eltávolítva a diszulfid hidakat az Aspergillus niger NRRL 3135 fitázából, különböző mutánsokat hoztak létre, s kifejeztették Pichia pastoris élesztőben. A mutáns fitázok számos változást mutattak az eredeti tulajdonságaikhoz képest. A 2-es híd eltávolítása a katalitikus aktivitás teljes elvesztését okozta. Az 1-es híd leválasztása az optimális hőmérséklet csökkenését eredményezte $58{ }^{\circ} \mathrm{C}$ fokról $53{ }^{\circ} \mathrm{C}$ fokra, míg a 3-as és 4-es diszulfid hidak hiánya esetén $37^{\circ} \mathrm{C}$-ra, az 5-ös eltávolításakor pedig $42{ }^{\circ} \mathrm{C}$-ra csökkent a hőmérséklet optimum. Ennek ellenére a diszulfid hidak nagyobb száma nem minden esetben eredményez magasabb hőoptimumot, ugyanis az A. ficuum (ULLAH \& MULLANEY 1996) $\mathrm{pH}=6,0$ optimummal rendelkező metalloenzime magasabb hőoptimummal rendelkezett, mint a phyA fitáza, pedig csak 6 ciszteinnel rendelkezett (10 helyett), bár a fehérje 23 hisztidinnel és 2 fémkötő hellyel bírt a phyA 9 hisztidinjével szemben. Ebben az esetben más lehet az oka a magasabb hőtürésnek.

\subsubsection{A fitáz előfordulása}

A fitáz enzim megtalálható a természetben, növényekben, állatokban és mikroorganizmusok széles köre termeli. A baktériumok, fonalas gombák és élesztők extra- és intracelluláris úton is előállítják, valamint sejthez kötött formában is előfordul. A továbbiakban részletesen bemutatom a különböző eredetű fitázok jellemzőit. 


\subsubsection{Növényi eredetü fitázok}

SUZUKI és munkatársai (1907) mutattak ki először fitáz aktivitást rizsben és búzakorpában. A fitáz enzim jelentős mennyiségben megtalálható még kukoricában, szójában, salátában, hüvelyesekben, valamint az olajos magvakban (VOHRA \& SATYANARAYANA 2003). EECKHOUT és PAEPE (1994) takarmánynövények fitáz aktivitását, valamint foszfor és fitát tartalmát vizsgálták. Jelentős mennyiségü fitáz aktivitást mutattak ki búzában, rozsban, árpában, tritikáléban, azonban zabban és cirokban minimális aktivitást mértek. Megállapították, hogy a fitáz aktivitás nem áll összefüggésben a növény teljes foszfor és a fitát-foszfor tartalmával. Azonos fajtáknak is lehet eltérő fitáz aktivitása a termesztési körülményektől függően, valamint a tárolás ideje és módja is meghatározó az enzimaktivitást illetően (BARRIER-GUILLOT et al. 1996). A magokban a fitáz enzim mind konstitutív, mind indukálható módon - a csírázás révén szintetizálódhat (NAYNI \& MARKAKIS 1986).

Szójababból izolált fitáz aminosav szekvenciája nem mutatott homológiát bármely eddig ismert hisztidinsavas foszfatázzal (MULLANEY et al. 2000). Hagymalevélből tisztított fitáz maximális aktivitást $51{ }^{\circ} \mathrm{C}$-on és $\mathrm{pH}=5$ értéken mutatott (PHILLIPPY 1998). Búzakorpából két frakciót különítettek el DEAE cellulózon LIU és munkatársai (1998), melyek szubsztrát bontása eltérőnek bizonyult. A növényi fitázok hőmérséklet stabilitása nem jó, túlmelegedés esetén, vagy a pelletálás során elveszítik aktivitásuk jelentős részét, ezért ipari alkalmazásuk nem sok előnnyel bír (RAVINDRAN et al. 1995).

\subsubsection{2 Állati eredetü fitázok}

McCollum és Hart számolt be először 1908-ban borjúmájban és vérben található fitázról. Alacsonyabbrendü gerincesek, úgymint madarak, hüllők, halak vérében is kimutatták. Mivel a takarmányban jelenlévő fitát antinutritív az állatokra nézve, ezért a fitáz enzim jelenlétét különféle állatok emésztőrendszerében vizsgálták. Patwardhan figyelt meg először fitinsav hidrolízist patkány bélrendszerében 1937-ben, majd 1972-ben Spitzer és Phillips sertés, bárány és szarvasmarha bélben mutattak ki fitáz aktivitást. Bitar és Reinhold szintén 1972-ben patkány, csirke, borjú és emberi bélrendszerből származó fitáz enzimet tisztítottak részlegesen. Az ember bélrendszerében mintegy 30-szor alacsonyabb fitáz aktivitást találtak a patkányéhoz képest. A legjelentősebb aktivitást a patkóbélben, míg a legkisebbet az csípőbélben detektálták (IQBAL et al. 1994). Négy lehetséges módja van a fitáz jelenlétének az állatok bélrendszerében: 1. a fitáz eredendően megtalálható a takarmány összetevőiben, 2. hozzáadott fitázt tartalmaz a takarmány, 3. a fitázt a bélmikrobiota termeli, 4. a bélnyálkahártya membránhoz fitáz enzim kötődik (ANGEL et al. 2002). A kérődzők a fitátok bontását feltehetően a bendőjükben lévő mikrobiota által termelt fitáz enzimmel végzik, s a felszabadult szervetlen foszfort mind a mikrobiota, mind a kérődző képes hasznosítani (VOHRA \& 


\subsubsection{Mikrobiális eredetü fitázok}

A mikroorganizmusok széles köre - baktériumok, élesztők és gombák - szintetizálnak fitáz enzimet különböző környezeti paraméterek mellett. SHIEH és WARE (1968) több mint 2000 termőföldből izolált mikroorganizmus fitáz aktivitását megvizsgáltak. A törzsek közül 30 mutatott extracelluláris fitáz aktivitást, s ezek mindegyike fonalas gomba eredetű: huszonnyolc az Aspergillus, egy a Penicillium és egy a Mucor nemzetségbe tartozott. A többi izolátum, köztük számos élesztő és baktérium, valamint a fennmaradó Aspergillus törzsek intracelluláris fitáz aktivitást mutattak. A legnagyobb aktivitást az A. ficuum NRRL 3135 törzs esetén mérték. 30 évvel később LIU és munkatársai (1998) több mint 200 gombafajt izoláltak az Aspergillus, Penicillium, Mucor és Rhizopus nemzetségekből és megállapították, hogy az általuk vizsgált izolátumok szintén extracelluláris fitáz aktivitással rendelkeztek.

Nagyszámú baktérium is szintetizál fitáz enzimet, melyek lokalizációja többnyire sejthez kötött, kivéve a Bacillus subtilis, a Lactobacillus amylovorus és az Enterobacter sp.4 fajokat. Számos élesztő esetében is tapasztaltak fitáz aktivitást, mint a Schwanniomyces castellii (LAMBRECHTS et al. 1992), Pichia anomala (VOHRA \& SATYARAYANA 2001), Arxula adeninivorans (SANO et al. 1999).

4. táblázat Kereskedelmi forgalomban lévő fitáz készítmények (CAO et al. 2007)

\begin{tabular}{|c|c|c|c|c|}
\hline Gyártó & Ország & Termelő törzs & Fitáz gén eredete & Márkanév \\
\hline AB Enzymes & Németország & T. reesei & A. awamori & Finase \\
\hline Alko Biotechnology & Finnország & A. oryzae & A. oryzae & SP,TP,SF \\
\hline Alltech & USA & A. niger & A. niger & Allzyme phytase \\
\hline BASF & Németország & A. niger & A. niger & Natuphos \\
\hline BioZyme & USA & A. oryzae & A. oryzae & AMAFERM \\
\hline DSM & USA & A. oryzae & P. lycii & Bio-Feed Phytase \\
\hline Fermic & Mexikó & A. oryzae & A. oryzae & Phyzyme \\
\hline $\begin{array}{l}\text { Finnfeeds } \\
\text { International }\end{array}$ & Finnország & T. reesei & A. awamori & Avizyme \\
\hline $\begin{array}{l}\text { Genecor } \\
\text { International }\end{array}$ & USA & P. funiculosum & P. simplicissium & ROVABIO \\
\hline Roal & Finnország & T. reesei & A. awamori & Finase \\
\hline Novozymes & Dánia & A. oryzae & A. oryzae & $\begin{array}{l}\text { Ronozyme } \\
\text { Roxazyme }\end{array}$ \\
\hline
\end{tabular}

Az iparban azonban a fonalas gomba eredetű fitáz enzimkészítmények alkalmazása a legelterjedtebb, melyek legfőképp Aspergillus eredetüek. Az első fitáz készítmény, mely a takarmányiparba betört, a Gist Brocades (ma DSM) által előállított Natuphos márkanevü termék. Por, granulátum és folyékony formában is értékesítették. Jelenleg az Európai Unióban takarmány 
adalékanyagként engedélyezett kereskedelemi forgalomban lévő fitáz készítményeket rekombináns DNS technika alkalmazásával nemesített mikroorganizmusokkal termeltetik. Ezek összefoglalása látható a 4. táblázatban. Egy Gist Brocades szabvány beszámol olyan Aspergillus ficuum törzsröl, mely fitáz túltermelő, és legalább 50-szeres aktivitás növekedést mutat, mint az eredeti törzs.

A szubmerz fermentációs előállítási technika mellett, egyre nagyobb szerepet játszik a szilárd szubsztrátumon történő fitáz enzim előállítás (EL-BATAL \& KAREM 2001, MANDVIWALA \& KHIRE 2000, BOGÁR et al. 2003).

\subsubsection{A fitáz szintézisét befolyásoló tényezők}

A fonalas gombák növekedési, fejlődési folyamatait nagymértékben befolyásolják a különböző környezeti paraméterek, a rendelkezésre álló tápközeg összetevők: a szén- és nitrogén források minősége és mennyisége, az ásványi elemek, növekedési faktorok. A gombák által termelt anyagcsere termékek - köztük az enzimek - szintézise is számos tényező függvénye, melyek hatása a következőkben kerül bemutatásra.

\subsubsection{A foszfor koncentráció hatása}

Az enzimreakciók során a szubsztrát koncentráció növelése kezdetben reakciósebesség növekedést eredményez, azonban túl sok átalakítandó anyag jelenléte a reakcióközegben szubsztrát gátlást okoz. Az enzimreakció következtében felszabadult nagy mennyiségű termék hasonlóan gátolhatja az átalakítási folyamatot. Szervetlen foszfor jelenléte mindenképp szükséges a fermentációs tápközegben az adott mikroba élettevékenységéhez. Számos kutatás alátámasztja azonban, hogy a tápközeg kezdeti foszfát koncentrációja fontos szerepet játszik a fitáz bioszintézise során (EBUNE et al. 1995, SHIEH \& WARE 1968, KIM et al. 1998). A fermentációs közeg alacsony foszfortartalma serkenti a fitáz termelődését, míg bizonyos koncentráció felett már represszálja az enzim bioszintézisét. E koncentráció azonban nehezen meghatározható, nagyrészt függ az alkalmazott mikroorganizmustól és a fermentációs tápközegtől. A fitáz szintézis foszfor általi gátlása feltehetően minden fitáz termelő fonalas gomba és élesztő esetén fennáll. Ezt a megállapítást támasztják alá többek között SHIEH és WARE (1968) eredményei, akik a foszfát koncentráció hatását vizsgálták A. ficuum NRRL 3135 törzs extracelluláris fitáz enzim termelése esetén. A különböző helyekről származó, eltérő foszfor tartalmú kukoricaliszteken végezett fitáz fermentációk során azt tapasztalták, hogy a nagy foszfor tartalom gátolja a fitáz termelést. A foszfor mennyiségének csökkentése a gomba növekedésére kedvezőtlen hatással volt, ezzel párhuzamosan a fitáz termelés megnövekedett. A maximális fitáz termelést az adott törzsnél $8 \%$ kukoricakeményítő tartalmú tápközegen akkor érték el, mikor a szervetlen foszfor koncentráció kisebb volt, mint 0,004 (w/v)\% (4 mg $\left.\mathrm{P}_{\mathrm{i}} / 100 \mathrm{ml}\right)$. Aspergillus sp. 307 törzs esetén is 
bebizonyították, hogy a foszfor koncentráció növelése 80-100 mg/l K2 $\mathrm{HPO}_{4}(4,4-5,5 \mathrm{mg} \mathrm{P}$ i/100 ml) mennyiségig növeli a biomassza tömeget, azonban a fitáz termelés $20 \mathrm{mg} / 1 \mathrm{~K}_{2} \mathrm{HPO}_{4}\left(1,1 \mathrm{mg} \mathrm{P} \mathrm{P}_{\mathrm{i}} / 100\right.$ ml) alkalmazásával maximális (GARGOVA et al. 1997). Savas foszfatáz aktivitást is kimutattak, melynél a maximális értéket még alacsonyabb, $10 \mathrm{mg} / 1 \mathrm{~K}_{2} \mathrm{HPO}_{4}(0,55 \mathrm{mg} \mathrm{P} / 100 \mathrm{ml})$ koncentráció esetén állapították meg. $100 \mathrm{~g}$ szilárd tápközeg alkalmazásakor $1 \mathrm{mg}$ foszfát $\left(\mathrm{P}_{\mathrm{i}}\right)$ eredményezte a maximális fitáz aktivitást Aspergillus ficuum esetén, míg $10 \mathrm{mg}$ foszfát felett az enzim termelődése gátlódott (EBUNE et al. 1995). VATS és BANERJEE (2004) 0,05 \% (50 mg $\mathrm{P}_{\mathrm{i}} / 100 \mathrm{ml}$ ) szervetlen foszfor koncentrációjú közegben már erős hanyatlást figyeltek meg az enzimtermelésben, 0,1\%

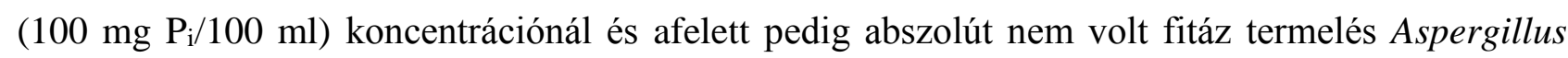
niger esetén.

Myceliophthora thermophile, termofil fonalas gomba fitáz termelése során maximális aktivitást 100 $\mathrm{mg} / \mathrm{l} \quad \mathrm{KH}_{2} \mathrm{PO}_{4} \quad\left(5,5 \mathrm{mg} \quad \mathrm{P}_{\mathrm{i}} / 100 \mathrm{ml}\right)$ alkalmazásával értek el (HASSOUNI et al. 2006). NAMPOOTHIRI és munkatársai (2004) szemiszintetikus tápközegben vizsgálták a foszfát koncentráció hatását a Thermoascus aurantiacus fitáz termelésére, különböző mennyiségű (0-4\%) $\mathrm{KH}_{2} \mathrm{PO}_{4}$

(0-2800 mg P $\mathrm{i} / 100 \mathrm{ml}$ ) alkalmazása mellett. Megállapították, hogy a foszfát tartalommal arányosan növekszik az aktivitás egészen $2 \%$-ig (1400 mg $\left.\mathrm{P}_{\mathrm{i}} / 100 \mathrm{ml}\right)$, ahol eléri a maximumot, majd a koncentráció további növelésével csökkenés mutatkozik az enzimtermelésben. A szabad foszfát tehát indukálja az enzim szintézisét egy bizonyos szintig, majd gátló hatás lép fel. Ezt támasztják alá AL-ASHEH és DUVNJAK (1995) eredményei is, akik 110 g szilárd szubsztrátumú tápközeget 1, illetve $5 \mathrm{mg}$ szervetlen foszfáttal $\left(\mathrm{P}_{\mathrm{i}}\right)$ kiegészítve az Aspergillus carbonarius jobb növekedését és fitáz enzim termelését tapasztalták. A foszfor koncentráció további növelésével - 50 és $100 \mathrm{mg}$ mennyiségben alkalmazva - negatív hatást mutattak ki mind a biomassza hozamra, mind a fitáz termelésre.

Összességében elmondható, hogy az extracelluláris gomba eredetü fitáz termelés indukálható, ha a szervetlen foszfát limitáló koncentrációban van jelen a tápközegben (DVOŘÁKOVÁ 1998). Az a szervetlen foszfát mennyiség, mely a maximális aktivitás eléréséhez és a gomba növekedéséhez elegendő azonban törzsenként változó.

\subsubsection{Az inokulum és a tápközeg összetétel hatása}

Fonalas gomba fermentációk esetén a morfológiai jellemzők szabályozása feltétele az ipari alkalmazásnak. Szubmerz kultúrában növekedésük változatos, a szétterjedt micéliumoktól kezdve lebegő micéliumként, csoportosan összetapadva növekedhetnek vagy gömbszerü micéliumképleteket produkálnak, amiket micéliális pelletnek nevezhetünk (MOREIRA et al. 1996). A különböző metabolit termékek képzése esetén előnyei illetve hátrányai is lehetnek az eltérö 
növekedési formáknak. A fonalas forma nagyobb sủrüségü, viszkozitású pszeudoplasztikus fermentációs közeget eredményez (KEITH \& COLIN 1992). A gombák pelletes növekedése kedvezőbb a fonalas növekedési formával szemben a legtöbb fermentációnál, mely nemcsak lehetővé teszi az ismételt szakaszos fermentációkat, de javítja a közeg reológiáját, mely jobb oxigén ellátást tesz lehetővé. Csökkenti továbbá az energia fogyasztást a levegőztetés és kevertetés során (LIAO et al. 2007a, VAN SUIJDAM et al. 1980). Másrészt hátránya lehet a pelletes növekedésnek, hogy az oxigén és egyéb tápanyagok diffúzióval történő bejutása a pellet belsejébe korlátozott, emiatt csökkenhet a növekedés és aktivitás (LÓPEZ et al. 2005). A felületaktív anyagok is hatással lehetnek a gomba morfológiájára, mégpedig a pelletes növekedés elősegítésével (LIAO et al. 2007b, ŽNIDARŠIČ et al. 2000). A gomba morfológiája befolyásolható továbbá a tápközeg összetételével, az inokulum korával, típusával, mennyiségével, a pH-val, kiegészítők (polimerek, felületaktív anyagok, kelátorok) alkalmazásával, a hőmérséklettel és a tápközeg viszkozitásával. Az egyes törzseknél eltérő jelentőségűek ezek a környezeti hatások: a Rhizopus törzseknek erős rázatásra, míg a Penicillium chrysogenum-nak magas pH-ra van szüksége a pelletek kialakításához (LIAO et al. 2007a). A $R$. oryzae törzsek anyagcseréje során fontos szerepet töltenek be a fém ionok, melyek jelenlétében a gomba szaporodása nagyon gyors, s nagy mennyiségü biomassza keletkezik. A gyors növekedésből adódóan azonban a fonalak összegabalyodnak, s ez nem kedvez a pelletes növekedési formának. Éppen ezért a fémionokat a pellet képződéséig mellőzik a tápközegből, majd a fermentáció során később adagolják. A tápközeg pH-ja szintén jelentősen befolyásolja a pellet képződést a különböző törzseknél. $R$. oryzae törzs esetében $\mathrm{pH}=3-7$ között nem tapasztaltak szignifikáns különbséget a pelletek képzésében, szemben az Aspergillus niger és $P$. chrysogenum törzsekkel. Az inokulum mennyisége is meghatározó, hisz a növekedés korai szakaszában nagy mennyiség esetén hamar csomók alakulnak ki, ezért a kisebb inokulum koncentráció előnyösebb lehet a pelletek kialakulására (LIAO et al. 2007a). A P. chrysogenum például kevés inokulum esetén pelleteket képez, nagy mennyiségü inokulum esetén fonalas növekedést eredményez. Az Aspergillus nidulans azonban kizárólag pelleteket képez (JAKUCS \& VAJNA 2003). KEITH és COLIN (1992) P. chrysogenum növekedésének vizsgálata során megállapították, hogy $5 \times 10^{5}$ konídium/ml felé emelve az inokulum mennyiségét éles különbség mutatkozott a pelletes és a fonalas forma között. A. niger citromsav fermentációja során $10^{4}$ és $10^{5}$ konídium/ml beoltási koncentrációval értek el $95 \%$ illetve $85 \%$-os pelletes növekedési formát PAPAGIANNI és MATTEY (2006). JOHANSEN és munkatársai (2008) Aspergillus awamori törzsnél vizsgálták a gomba morfológiája, valamint a heterológ fehérje termelés közötti kapcsolatot 20 literes kevertetett bioreaktorban. A különböző kevertetési sebesség és az inokulum koncentrációja nagymértékben meghatározta a hifák hosszát, valamint a csúcsok számát a fermentáció során. A csökkent inokulum koncentráció elágazóbb micéliumot eredményezett. 
Megállapították, hogy a szerkezeti különbségek, mint a hifa hossza és az elágazások száma nem befolyásolja jelentősen a termékképzést.

Az összefüggést a fitáz enzim termelés hatékonysága és az inokulum morfológiája között PAPAGIANNI és munkatársai (1999) vizsgálták A. niger esetén. Búzakorpa jelenlétében az inokulumban a pelletek egyenletes, sima felszínü és csomós formában nőttek, mely kedvező volt a biomassza és fitáz termeléshez mind szubmerz, mind szilárd szubsztrátumú fermentációk esetén. Korpa nélkül nagy pelletek képződtek és a termelékenység csökkent. HASSOUNI és munkatársai (2006) egy termofil gomba, a Myceliophthora thermophila fitáz termelését vizsgálták, s megállapították, hogy ha 0,25 g/l fitinsavat adagoltak a burgonya-glükóz tápközeghez az inokulum készítése során, az enzim termelés megnövekedett. NAMPOOTHIRI és munkatársai (2004) $6 \mathrm{x} \quad 10^{7} \mathrm{db} / \mathrm{ml}$ T. aurantiacus spóra szuszpenziót alkalmazva érte el a maximális enzimaktivitást. Az ennél kisebb vagy nagyobb mennyiség kedvezőtlenül hatott a fitáz termelésre.

$\mathrm{Az}$ inokulum mellett a fermentációs tápközeg összetétele, különös tekintettel a szén- és nitrogén források, is meghatározóak az enzimtermelést illetően. Az 5. táblázatban a mezofil és termofil mikroorganizmus eredetü fitázok fermentációs körülményeit, s az alkalmazott tápközegek föbb komponenseit foglaltam össze.

A búzakorpa, egy általánosan használt mezőgazdasági termék, mely elsősorban szilárd szubsztrátumú fonalas gomba fermentációknál aknázható ki enzimtermelésre. Mindazon alapvető összetevőket tartalamazza - szén-, nitrogénforrás és aminosavak -, melyek létfontoságúak a gomba számára. Szubmerz fitáz fermentációknál a búzakorpát illetve búzakorpa kivonatokat kiegészítésként alkalmazták NAMPOOTHIRI és munkatársai (2004) Thermoascus aurantiacus esetén, s módszerükkel az enzimtermelés fokozását érték el.

A búzakorpa mellett szubmerz fermentációk esetén a keményítő alapú tápközegek használata terjedt el. HASSOUNI munkatársaival (2006) a legnagyobb fitáz aktivitást glükóz egyedüli szénforrásként való alkalmazása során érték el. Keményítő vagy szacharóz esetén is tapasztaltak aktivitást, mely kisebb mértékü volt, mint glükóz esetén. SHIEH és WARE (1968) szintén glükózt vagy szacharózt alkalmazott egyedüli szénforrásként $A$. ficuum NRRL 3135 törzs extracelluláris fitáz enzim termelésére. Az egyszerü cukrok alkalmazása pelletes növekedést és kis fitáz hozamot eredményezett.

NAMPOOTHIRI és munkatársai (2004) a peptont találták legjobb nitrogén forrásnak a Thermoascus aurantiacus-szal megvalósított fitáz enzim termelésére, mely hasonlóan egy másik termofil gomba, a Sporotrichum thermophile (SINGH \& SATYANARAYANA 2008) fitáz termeléséhez is kedvezőnek bizonyult. A mezofil gombák közül az Aspergillus fajok fitáz termelését különböző kutatócsoportok (GARGOVA et al. 2006, SARIYSKA et al. 2005, BHAVSAR et al. 2011) is a $\mathrm{NaNO}_{3}$ tartalmú tápközegben valósították meg. 
5. táblázat Mezofil és termofil mikroorganizmus eredetü fitázok termelésének és egyes biokémiai jellemzőinek összefoglalása

\begin{tabular}{|c|c|c|c|c|c|c|}
\hline \multirow{2}{*}{$\begin{array}{c}\text { MIKRO- } \\
\text { ORGANIZMUS }\end{array}$} & \multicolumn{3}{|c|}{ FITÁZ TERMELÉS } & \multicolumn{2}{|c|}{$\begin{array}{c}\text { FITÁZ BIOKÉMIAI } \\
\text { JELLEMZŐI }\end{array}$} & \multirow{2}{*}{ HIVATKOZÁS } \\
\hline & $\begin{array}{l}\text { Fermentá- } \\
\text { ció típusa }\end{array}$ & Szénforrás & $\begin{array}{l}\text { Nitrogén } \\
\text { forrás }\end{array}$ & pH opt. & $\begin{array}{l}\text { T opt. } \\
\left({ }^{\circ} \mathrm{C}\right)\end{array}$ & \\
\hline \multicolumn{7}{|c|}{ Mezofil mikroorganizmusok } \\
\hline Aspergillus niger & SSF & búzakorpa & & 5,0 & 55 & GREINER et al. 2009 \\
\hline Aspergillus niger 307 & $\mathrm{SmF}$ & $\begin{array}{l}\text { kukorica } \\
\text { keményítő, } \\
\text { glükóz }\end{array}$ & $\mathrm{NaNO}_{3}$ & 2,1 & 66 & $\begin{array}{l}\text { GARGOVA et al. } \\
2006\end{array}$ \\
\hline Aspergillus niger 307 & $\mathrm{SmF}$ & $\begin{array}{l}\text { kukorica } \\
\text { keményítő, } \\
\text { glükóz }\end{array}$ & $\mathrm{NaNO}_{3}$ & $\begin{array}{l}2,62 \\
5,05\end{array}$ & $\begin{array}{l}58 \\
55\end{array}$ & $\begin{array}{l}\text { SARIYSKA et al. } \\
2005\end{array}$ \\
\hline $\begin{array}{l}\text { Aspergillus niger } \\
\text { NCIM } 563\end{array}$ & SSF & $\begin{array}{l}\text { búzakorpa, } \\
\text { glükóz, } \\
\text { dextrin }\end{array}$ & $\mathrm{NaNO}_{3}$ & 6 & 55 & $\begin{array}{l}\text { BHAVSAR et al. } \\
2011\end{array}$ \\
\hline Arxula adeninivorans & $\mathrm{SmF}$ & galaktóz & $\begin{array}{l}\text { élesztő- } \\
\text { kivonat }\end{array}$ & 4,5 & 75 & SANO et al. 1999 \\
\hline Mucor hiemalis & $\mathrm{SmF}$ & $\begin{array}{l}\text { kukorica } \\
\text { keményítő, } \\
\text { glükóz }\end{array}$ & $\mathrm{NaNO}_{3}$ & $5,0-5,5$ & 55 & $\begin{array}{l}\text { BOYCE \& WALSH } \\
2007\end{array}$ \\
\hline B. subtilis & $\mathrm{SmF}$ & glükóz & $\mathrm{NH}_{4} \mathrm{NO}_{3}$ & 7,0 & 55 & $\begin{array}{l}\text { KEROVUO et al. } \\
1998\end{array}$ \\
\hline $\begin{array}{l}\text { Saccharomyces } \\
\text { cerevisiae CY }\end{array}$ & $\mathrm{SmF}$ & glükóz & $\begin{array}{l}\text { élesztő és } \\
\text { malátakivo- } \\
\text { nat, pepton }\end{array}$ & 3,6 & 40 & IN et al. 2009 \\
\hline \multicolumn{7}{|c|}{ Termofil mikroorganizmusok } \\
\hline A. fumigatus $W Y-2$ & $\mathrm{SmF}$ & $\begin{array}{l}\text { hylon } \\
\text { keményítő }\end{array}$ & $\mathrm{NaNO}_{3}$ & 5,5 & 55 & WANG et al. 2007 \\
\hline $\begin{array}{l}\text { Thermoascus } \\
\text { aurantiacus }\end{array}$ & $\mathrm{SmF}$ & $\begin{array}{l}\text { keményítő, } \\
\text { glükóz, } \\
\text { búzakorpa }\end{array}$ & Pepton & & 55 & $\begin{array}{l}\text { NAMPOOTHIRI et } \\
\text { al. } 2004\end{array}$ \\
\hline $\begin{array}{l}\text { Myceliopthora } \\
\text { thermophila Lomy } 713\end{array}$ & SSF & $\begin{array}{l}\text { glükóz, } \\
\text { fitinsav }\end{array}$ & $\left(\mathrm{NH}_{4}\right)_{2} \mathrm{HPO}_{4}$ & 5,5 & $45-50$ & $\begin{array}{l}\text { HASSOUNI et al. } \\
2006\end{array}$ \\
\hline Rizomucor pusillus & SSF & búzakorpa & $\begin{array}{l}\text { aszparagin } \\
\text { CSL }\end{array}$ & 5,4 & 70 & CHADHA et al. 2004 \\
\hline $\begin{array}{l}\text { Sporotrichum } \\
\text { thermophile }\end{array}$ & $\mathrm{SmF}$ & búzakorpa & Pepton & 5,5 & 60 & $\begin{array}{l}\text { SINGH \& } \\
\text { SATYANA- } \\
\text { RAYANA } 2008 \\
\end{array}$ \\
\hline $\begin{array}{l}\text { Thermomyces } \\
\text { lanuginosus }\end{array}$ & $\mathrm{SmF}$ & $\begin{array}{l}\text { malto- } \\
\text { dextrin }\end{array}$ & $\begin{array}{l}\text { urea, } \\
\text { aszparagin }\end{array}$ & 6,0 & 65 & BERKA et al. 1998 \\
\hline $\begin{array}{l}\text { Thermomyces } \\
\text { lanuginosus } T L-7\end{array}$ & SSF & búzakorpa & $\mathrm{NaNO}_{3}$ & 5,0 & 70 & GULATI et al. 2007b \\
\hline Bacillus laevolacticus & $\mathrm{SmF}$ & $\begin{array}{l}\text { szacharóz, } \\
\text { borsó liszt }\end{array}$ & $\mathrm{NH}_{4} \mathrm{H}_{2} \mathrm{PO}_{4}$ & $7-8$ & 70 & GULATI et al. 2007a \\
\hline
\end{tabular}

SmF - szubmerz fermentáció, SSF - szilárd szubsztrátumú fermentáció

\subsubsection{Felületaktív anyagok hatása}

Felületaktív anyagoknak nevezzük azokat a vegyületeket, amelyek hidrofil és hidrofób részeket is tartalmaznak, így képesek poláris/apoláris határfelületeknél orientálódni, valamint egy meghatározott koncentráció felett micellákat képezni, hogy ezáltal elősegítsék a vízben rosszul 
oldódó vegyületek oldódását (YALKOWSKY 1999). A felületaktív anyagoknak, vagy detergenseknek három típusa van a molekula töltése szerint: lehetnek anionos, kationos és nemionos detergensek. Ez utóbbihoz tartozik a Triton X-100, valamint a különböző polimerizáltsági fokú poliszorbátok (Tween sorozat). A polietilén-glikol-szorbát zsírsavak észtereit széles körben alkalmazzák élelmiszer adalékanyagként, valamint gyógyszerkészítmények előállítása során emulgeáló és stabilizáló szerként.

A Tween sorozat tagjai a következők:

Tween-20 - poliszorbát 20 [polioxi-etilén(20)-szorbitán-monolaurát] (laurinsavas észter)

Tween-40 - poliszorbát 40 [polioxi-etilén(20)-szorbitán-monopalmitát] (palmitinsavas észter)

Tween-60 - poliszorbát 60 [polioxi-etilén(20)-szorbitán-monosztearát] (sztearinsavas észter)

Tween-65 - poliszorbát 65 [polioxi-etilén(20)-szorbitán-trisztearát] (sztearinsavas észter)

Tween-80 - poliszorbát 80 [polioxi-etilén(20)-szorbitán-monooleát] (olajsavas észter)

Tween-85- [polioxi-etilén(20)-szorbitán-monooleát] (olajsavas észter)

A Triton X-100 egy hidrofil polietilén-oxid lánc és egy aromás szénhidrogén csoportból áll, mely hidrofób vagy lipofil. Ezt a felületaktív anyagot általában a sejt lizáló pufferek, valamint egyéb a fehérjék kinyerésére és oldására szolgáló összetevőként alkalmazzák, de a papír és textiliparban, valamint olajipari vegyszerként és fémmegmunkáló folyadékként is felhasználásra kerülhet.

A felületaktív anyagok hatását számos kutatócsoport vizsgálja, ugyanis a fermentáció során a mikroorganizmus növekedését és enzimtermelését is befolyásolják. Általában az enzimhozam növelésére alkalmazzák, mivel a felületaktív anyagok hidrofób része lehetővé teszi, hogy könnyedén behatoljanak a kettős lipidrétegbe megváltoztatva a lipid metabolizmust, ezáltal növelik a sejtfal áteresztő-képességét, mely az extracelluláris enzimek nagyobb mértékü kiválasztását teszi lehetővé. A foszfolipidek zsírsav-acil-láncai, továbbá a telített és telítetlen zsírsavak aránya az egyik legfontosabb tényező a membrán áteresztőképessége és sértetlensége szempontjából. A kisebb arány jobb permeabilitást mutat. Szterolok szintén részt vesznek a membrán megfelelő müködésének fenntartásában, és megváltozott szintjük a membrán permeabilitás és membrán-asszociált funkciók, mint például a membránhoz kötött enzimek tevékenységét befolyásolják (NEMEC \& JERNEJC, 2002). A mechanizmus különböző mikroorganizmusok különböző enzimei esetén eltérő lehet. NAMPOOTHIRI és munkatársai (2004) Thermoascus aurantiacus búzakorpa tartalmú tápközegben megvalósított szubmerz fermentációja során vizsgálták a Triton X-100, Tween-80, Tween-40, és Tween-20 hatását az enzimtermelésre $0-4 \%[\mathrm{v} / \mathrm{v}]$ koncentrációban alkalmazva. A legnagyobb fitáz aktivitást a Tween80 0,5\%[v/v] koncentrációban történő alkalmazása esetén érték el. 
A. niger szilárd szubsztrátumú fitáz fermentációjában Tween-20, Tween-40, Tween-60, Tween-80 és Triton X-100 kiegészítést $0,5 \%$ koncentrációban alkalmazva, a legnagyobb aktivitás növekedés Tween-80 és Tween-60 alkalmazásával érhető el (EL-BATAL \& KAREM 2001). E felületaktív anyagokkal $11 \%$ illetve $8 \%$-kal fokozható az enzimtermelés. A Tween 80 mennyiségi optimálása során a $0,3 \%$ koncentráció alkalmazásával érték el a legnagyobb fitáz mennyiséget.

Szintén az A. niger NCIM 563 törzsnél a fitáz termelés hatékonyságát fokozták SONI és KHIRE (2007) Tween-80 felületaktív detergenssel, melyet a 3. napon $0,5 \%$ koncentrációban adtak a fermentációs tápközeghez. Ezzel a módszerrel az enzim termelésben jelentős növekedést értek el, 35\%-kal növekedett az aktivitás $\mathrm{pH}=2,5$ esetén és 43\%-kal $\mathrm{pH}=4$ értéken. ARNESEN és munkatársai (1998) a Thermomyces lanuginosus $\alpha$-amiláz termelését vizsgálták dextránt alkalmazva szénforrásként. A Tween 80 1,3\% koncentrációban való alkalmazása hatszoros fehérje növekedést eredményezett, vagyis egy általános fehérje szekréciót elősegítő szernek bizonyult T. lanuginosus esetében. Az enzimtermelésnek pedig 2,7-szeres növekedését érték el alkalmazásával. Ezzel szemben a Triton-X 100 azonos koncentrációban való alkalmazása nem befolyásolta az enzim termelést, sőt a gomba növekedését is gátolta. A Triton X-100 enzimaktivitás növelő hatásáról ellentétes eredmények olvashatók a szakirodalomban. EBUNE és munkatársai (1995) tapasztalatai alapján az A. ficuum fitáz enzime gátlódott a Triton X-100 használata során, ugyanezt tapasztalták EL-BATAL és KAREM (2001) A. niger, valamint AL-ASHEH és DUVNJAK (1994) A. carbonarius fitáz enziménél.

\subsubsection{A fitáz enzim jellemzése}

Az emésztőrendszerben lévő fitát-foszfor hidrolíziséhez alkalmazandó fitáz enzim jellemzése meghatározó, hiszen a katalitikus hatékonyság, a szubsztrát specifitás, a hőmérséklet és pH optimum, valamint a proteolízissel szembeni ellenállás mind-mind befolyásolja egy enzim alkalmazhatóságát adott területen. Takarmány kiegészítőként alkalmazva a fitáz a gyomorban fejti ki hatását, nagyon fontos tehát, hogy $\mathrm{pH}$ optimuma az alacsony illetve savas tartományban legyen, valamint, hogy ellenálljon a pepszin fehérjebontó hatásának. Sertés és baromfi takarmányok előállítása során alkalmazott $65-80{ }^{\circ} \mathrm{C}$-os pelletálási hőmérséklettel szemben is ellenállónak kell lennie az adott fitáz enzimnek. Ugyanakkor alacsonyabb hőoptimumú enzim alkalmazása szükséges az alacsonyabb testhőmérsékletű halak esetén, mint pl. a baromfiknál vagy a sertéseknél (LEI \& STAHL 2001). Az enzim ipari alkalmazhatóságát nagymértékben meghatározó tényezőket az alábbiakban foglalom össze. 


\subsubsection{Szubsztrát specifitás}

A szubsztrát specifitás és affinitás fontos jellemzője az enzimeknek, s szoros kapcsolatban van a szubsztrátum fiziológiai természetével. A fitáz enzim számára különböző foszfát csoportot tartalmazó vegyületek szolgálnak szubsztrátumként. Átalakítandó alapanyag lehet például a fitinsav és egyes sói, a cukorfoszfátok (glükóz-6-foszfát, ribóz-5-foszfát, fruktóz-6-foszfát stb), AMP, ADP, ATP, PEP, $\mathrm{NADH}_{2}$, riboflavin-foszfát. A legáltalánosabban használt szubsztrátum a fitinsav (MISSET 2003). A lúgos fitázok szubsztrát specifitása szükebb a savas foszfatázénál, ezeknek jellemzően a Ca-fitát a szubsztrátumuk. Eltérő a szubsztrát specifitása a különböző eredetü enzimeknek is. A mikrobiális eredetü fitázok a fitinsav szubsztrátummal szemben mutatják a legnagyobb affinitást, míg a növényi eredetű és az egyes gomba eredetü enzimek szélesebb szubsztrát specifitásúak, és a kevésbé szubsztituált mioinozit-foszfátokat is hidrolizálják (LEI \& PORRES 2003). Erre mutat néhány példát a 6. táblázat. Az A. niger phyA enzime a Na-fitátot bontja legnagyobb mértékben, ezzel szemben a phyB enzim ezt a szubsztrátot hasznosítja legkevésbé a táblázatban feltüntetett anyagok közül. Fruktóz-1,6-difoszfáthoz 20-szoros, pnitrofenil-foszfáthoz és glükóz-6-foszfáthoz 10-szeres az affinitása a Na-fitáthoz viszonyítva. A. fumigatus fitáza szintén e két utóbbi szubsztráthoz mutatja a legnagyobb affinitást, ellenben az AMP, fruktóz-6-foszfát vagy ribóz-5-foszfát esetében a relatív aktivitás messze elmarad a $100 \%$ ként feltüntetett Na-fitátétól.

\section{6. táblázat. Különböző eredetű hisztidinsavas foszfatázok szubsztrát specifitása}

(OH et al. 2004 nyomán)

\begin{tabular}{|c|c|c|c|c|c|}
\hline \multirow[b]{2}{*}{ Szubsztrát } & \multicolumn{5}{|c|}{ Relatív aktivitás (\%) } \\
\hline & $\begin{array}{c}\text { A. niger } \\
\text { (phyA) }\end{array}$ & $\begin{array}{c}\text { A. niger } \\
(\text { phyB })\end{array}$ & A. fumigatus & E. coli & Repce \\
\hline Na-fitát & 100 & 100 & 100 & 100 & 100 \\
\hline P-nitrofenil-foszfát & 66 & 1125 & 393 & 12,3 & 890 \\
\hline Fruktóz-1,6-biszfoszfát & 27,3 & 2125 & 393 & 8,5 & - \\
\hline Fruktóz-6-foszfát & 2 & 437 & 43 & 1,3 & - \\
\hline Glükóz-6-foszfát & 13 & 1062 & 125 & - & - \\
\hline Ribóz-5-foszfát & 2 & 562 & 36 & - & - \\
\hline 3-foszfoglicerát & 3 & 750 & 129 & - & - \\
\hline Na-pirofoszfát & 19,4 & - & 136 & - & 23190 \\
\hline AMP & 0 & 150 & 14 & 0,4 & - \\
\hline ADP & 8 & 625 & 64 & - & - \\
\hline ATP & 48 & 875 & 86 & 0,9 & 17545 \\
\hline
\end{tabular}

GULATI és munkatársai (2007b) a T. lanuginosus fitáz enzimének szubsztrát specifitását vizsgálták, $5 \mathrm{mM}$ koncentrációban alkalmazva a következő anyagokat: Na-fitát, Ca-fitát, riboflavinfoszfát, AMP, ADP, ATP, p-nitrofenil-foszfát, $\mathrm{NADPH}_{2} * \mathrm{Na}_{2}$, fenil-foszfát, foszfoenol-piruvát. 
Na-fitáthoz képest ADP és riboflavin-foszfát alkalmazásával értek el nagyobb aktivitást, míg ATP szubsztrátumon nem mutatott aktivitást az enzim.

Mucor hiemalis savas foszfatáza szubsztrát specifitás tekintetében az A. niger phyB enziméhez hasonló, ugyanis p-nitrofenil-foszfát szubsztrátumon kb. 10-szeres az aktivitása összehasonlítva Na-fitáttal. Ha a p-nitrofenil-foszfát szubsztrátumon mért enzimaktivitást tekintjük $100 \%$-nak, fenil-foszfáton szintén közel $100 \%$ az aktivitás, ATP esetén $90 \%$, míg Na-fitáton $10 \%$ (BOYCE \& WALSH 2007).

\subsubsection{2 pH és hömérséklet optimum}

Az enzimek ipari alkalmazhatóságának feltétele, hogy biztosítsuk müködésük optimális körülményeit, éppen ezért a pH és hőmérséklet optimum ismerete alapvető az enzimes reakciók során. A hidrogénion koncentráció befolyásolhatja az enzim térszerkezetét, a katalitikus hely müködését, illetve hatással lehet a szubsztrát kötődésére. Az optimálistól eltérő körülmények között a fehérjemolekula egyre nagyobb mértékben denaturálódik, s elveszti katalizáló tulajdonságát. A enzimek által katalizált folyamatokat a hőmérséklet is befolyásolja. $10^{\circ} \mathrm{C}$-os hőmérséklet emeléssel a reakciósebesség egy adott hőmérsékletig megduplázható, azonban az enzimek fehérje természetéből kifolyólag, a hőmérséklet további emelése a fehérjék denaturálását okozza. Ennek során az enzimmolekulákban lévő aktív térszerkezetet fenntartó kötések a hömérséklet emelésére meglazulnak, majd felbomlanak. A megváltozott szerkezetű enzim már nem alkalmas katalitikus funkciójának betöltésére. Egy enzim a számára optimális körülmények között mutatja aktivitásának maximumát, de nagyon lényeges jellemző az enzim stabilitása is az adott hőmérséklet és $\mathrm{pH}$ értéken. Mivel a különböző eredetű mikrobák eltérő tulajdonságú fitáz enzimet termelnek, fontos azon tulajdonságú törzsek megtalálása vagy létrehozása, melyek az adott folyamatot leghatékonyabban katalizálják. Az 5. táblázatban különböző termofil és mezofil mikroorganizmus eredetü fitáz enzimek pH és hőmérséklet optimumát tüntettem fel.

A legtöbb fitáz $\mathrm{pH}$ optimuma savas tartományban, $\mathrm{pH}=4,5-6$ érték között van, míg a Bacillus $s p$. eredetü fitázok jellemzője a semleges vagy lúgos tartományban található pH optimum. NAKAMURA és munkatársai (2000) számos élesztő fitáz enzimének pH és hőmérséklet optimum meghatározása során megállapították, hogy az optimális érték a pH=4-5 közötti, s az igen magas, $60-80^{\circ} \mathrm{C}$ hőmérséklet. A Saccharomyces cerevisiae fitáza ennél enyhén savasabb, $\mathrm{pH}=3,6$ értéken müködik optimálisan, s egyes Aspergillus niger eredetü fitázoknak két $\mathrm{pH}$ opimuma van, $\mathrm{pH}=2,5$ valamint $\mathrm{pH}=5,5$ értéknél, a két pont között pedig csökkenő aktivitás figyelhető meg (ULLAH \& GIBSON 1987, SARIYSKA et al. 2005). Aspergillus ficuum NTG-23 mutáns törzs fitáz enzimének $\mathrm{pH}$ optimuma 1,3. A pH semleges irányba tolásával az aktivitás csökken, $\mathrm{s} \mathrm{pH}=5,2$ felett 
megszünik. Optimális hőmérséklete $67^{\circ} \mathrm{C}$, s egy óra alatt $70^{\circ} \mathrm{C}$-on csak $14 \%$ az aktivitás csökkenés (ZHANG et al. 2010).

A legtöbb növényi és mikrobiális fitáz hömérséklet optimuma $45-60{ }^{\circ} \mathrm{C}$ között van. A viszonylag magas hőmérséklet optimum miatt a fitáz kevésbé aktív a sertések és a baromfi gyomrának hőmérsékletén $\left(37-40{ }^{\circ} \mathrm{C}\right)$, s még kevésbé hatékony halak esetében. Az enzim állattenyésztésben való alkalmazhatóságának feltétele azonban, hogy hőstabil legyen és ellenálljon a magas, $60-90^{\circ} \mathrm{C}$ közötti hőmérsékletnek, melyet a takarmány pelletálása során elérhetnek. A többi fehérjéhez hasonlóan a fitázok hőstabilitása is az a képesség, amely ellenállóvá teszi a hődenaturálással szemben - hipertermofil organizmusok esetében - és/vagy a hődenaturáció után képes megfelelően visszacsavarodni természetes állapotába (WYSS et al. 1999). A. fumigatus, A. niger és egy $\mathrm{pH}=2,5$ optimummal is rendelkező A. niger hisztidinsavas foszfatáz enzimének termostabil jellemzőit nézték WYSS és kutatócsoportja (1998). A. fumigatus fitáza $90^{\circ} \mathrm{C}$ hődenaturálás után teljesen aktív szerkezettel visszaállt natív konformációjába.

Hőstabil enzimek keresése vagy létrehozása random és helyspecifikus mutagenezissel egy lehetőség kedvezőbb tulajdonsággal bíró fitáz enzimek takarmányozásban való alkalmazásához. A. fumigatus phyA génjét $A$. niger-ben fejeztették ki, mely hőstabil fitázt termel. Az enzim $100{ }^{\circ} \mathrm{C}$ hőmérsékleten 20 perc után csupán $10 \%$ enzimaktivitás csökkenést mutat. Széles pH tartományban $(\mathrm{pH}=2,5-7,5)$ hidrolizálja a fitinsavat (PASAMONTES et al. 1997). Pichia pastoris élesztőben fejeztették ki A. fumigatus WY-2 termostabil fitáz génjét (WANG et al. 2007), valamint A. niger N-3 génjét (SHI et al. 2009), melyek maradék aktivitása $90^{\circ} \mathrm{C}$-os hőkezelést követően $43,7 \% 15$ perces hőkezelés után. Ez utóbbi törzs fitáz enzimének további jellemzője, hogy két pH optimummal rendelkezik ( $\mathrm{pH}=2$ és $\mathrm{pH}=5,5)$, s a savasabb értéken 30\%-kal nagyobb aktivitást mutat, mely tulajdonság kedvező a monogasztrikus állatok gyomrában való túlélésre. A termostabilis enzimek legfőbb hátránya, hogy többnyire kis specifikus aktivitást mutatnak szobahőmérsékleten, $\mathrm{s}$ ez összefüggésben van a fehérje merevségével és csökkent rugalmasságával. A fitázok kémiai burkolása megnöveli hőstabilitásukat, de a burkolás némiképp csökkenti az enzim müködőképességét a gyomorban.

A kalcium jelenléte bizonyos fitáz enzimek működéséhez nélkülözhetetlen, stabilizáló hatása van, mely véd a hődenaturációtól. Ezt bizonyítják a Bacillus sp. DSll fitáza esetén tapasztaltak, miszerint az enzim stabilitása már $50^{\circ} \mathrm{C}$-on drasztikusan csökkent kalcium hiányában, míg $5 \mathrm{mM} \mathrm{CaCl}$ jelenlétében, 10 perces $90^{\circ} \mathrm{C}$-on történő hőkezelést követően is $50 \%$ volt a maradék aktivitás (KIM et al. 1998). B-propeller fitázok kristályszerkezetének elemzését elvégezték kalciummal részlegesen vagy teljesen telített állapotban (HA et al. 2000). A termostabilitásban nagy mértékü $-\mathrm{kb} .30^{\circ} \mathrm{C}-$ növekedést jelentett az enzim nagy affinitású kalcium-kötő helyein 2 kalcium ion megkötése, mellyel a távoli hurok szegmensek összekapcsolódtak. További három kalcium-ion megkötése a 
molekula tetején, az alacsony affinitású kötőhelyeken, elősegíti az enzim katalitikus aktivitásának növelését. Az erősen negatív töltésű hasadék a fitát megkötésére kedvezőbb körülményeket tesz lehetővé.

\subsubsection{Aktivátorok, inhibitorok}

Az enzimek aktivitása jelentősen befolyásolható különböző ionok, vegyületek alkalmazásával. Ezek jelenléte miatt az enzimaktivitás fokozódása vagy gátlása figyelhető meg, de egyes vegyületek sem pozitív, sem negatív hatást nem fejtenek ki az enzim müködésére. Ezen túlmenően hozzájárulhatnak az enzim stabilitásához, illetve a szubsztrátum felismeréséhez is. A gátló vagy serkentő hatás függ az adott ion koncentrációjától is, mely befolyásolja a fehérjék hidratációját, s ezáltal azok szerkezetét.

Az enzim eredetétől függően a fémek szerepe igen változatos lehet. A 7. táblázatban különböző fémionok élesztő, fonalas gomba, baktérium és növényi eredetű fitázokra gyakorolt hatása látható.

7. táblázat Fémionok hatása a különböző eredetü fitázok aktivitásra (LIU et al. nyomán 1998)

\begin{tabular}{|c|c|c|c|c|c|c|}
\hline \multirow{2}{*}{ IONOK } & \multicolumn{6}{|c|}{ FORRÁS } \\
\hline & A. ficuum & B. subtilis & Enterobacter & S. castellii & Kukorica & Szójabab \\
\hline$\overline{\mathrm{Al}^{3+}}$ & - & I I (5 mM) & I $\mathrm{I}(1 \mathrm{mM})$ & $\overline{-1}$ & $\overline{-1}$ & $\overline{\mathrm{N}} \mathrm{N}(1 \mathrm{mM})$ \\
\hline $\mathrm{Ba}^{2+}$ & - & $\mathrm{I}(0,5 \mathrm{mM})$ & $\mathrm{I}(1 \mathrm{mM})$ & - & - & - \\
\hline $\mathrm{Ca}^{2+}$ & $\mathrm{N}(50 \mu \mathrm{M})$ & $\mathrm{S}(5 \mathrm{mM})$ & - & $\mathrm{M}(5 \mathrm{mM})$ & $\mathrm{S}(2 \mathrm{mM})$ & $\mathrm{N}(1 \mathrm{mM})$ \\
\hline $\mathrm{Co}^{2+}$ & $\mid \mathrm{S}(50 \mu \mathrm{M})$ & $\mathrm{I}(5 \mathrm{mM})$ & - & - & - & $\mathrm{N}(1 \mathrm{mM})$ \\
\hline $\mathrm{Cu}^{2+}$ & $\mathrm{I}(50 \mu \mathrm{M})$ & $\mathrm{I}(5 \mathrm{mM})$ & I ( $1 \mathrm{mM})$ & $\mathrm{I}(0,5 \mathrm{mM})$ & - & I (1 mM) \\
\hline $\mathrm{Fe}^{2+}$ & $\mathrm{N}(50 \mu \mathrm{M})$ & $\mathrm{I}(5 \mathrm{mM})$ & - & $\mathrm{I}(5 \mathrm{mM})$ & $\mathrm{I}(0,25 \mathrm{mM})$ & $\mathrm{N}(1 \mathrm{mM})$ \\
\hline $\mathrm{Hg}^{2+}$ & - & $\mathrm{I}(0,5 \mathrm{mM})$ & - & - & - & I (1 mM) \\
\hline $\mathrm{Mn}^{2+}$ & $\mathrm{S}(50 \mu \mathrm{M})$ & $\mathrm{I}(5 \mathrm{mM})$ & I (1 mM) & $\mathrm{I}(5 \mathrm{mM})$ & $\mathrm{N}(2 \mathrm{mM})$ & $\mathrm{M}(1 \mathrm{mM})$ \\
\hline $\mathrm{Mg}^{2+}$ & - & $\mathrm{I}(5 \mathrm{mM})$ & $\mathrm{M}(1 \mathrm{mM})$ & $\mathrm{M}(1 \mathrm{mM})$ & $\mathrm{N}(2 \mathrm{mM})$ & $\mathrm{M}(1 \mathrm{mM})$ \\
\hline $\mathrm{Sr}^{2+}$ & - & $\mathrm{I}(0,5 \mathrm{mM})$ & - & - & - & - \\
\hline $\mathrm{Zn}^{2+}$ & $\mid \mathrm{I}(50 \mu \mathrm{M})$ & $\mathrm{I}(5 \mathrm{mM})$ & $\mathrm{I}(1 \mathrm{mM})$ & $\mathrm{I}(0,5 \mathrm{mM})$ & $\mathrm{I}(0,25 \mathrm{mM})$ & I (1 mM) \\
\hline
\end{tabular}

A zárójelben az alkalmazott koncentrációk találhatók.

Az Aspergillus ficuum-ból izolált fitáz enzim különböző érzékenységgel reagált a különböző fémionokra. Nem figyeltek meg gátlást $\mathrm{Ca}^{2+}$ és $\mathrm{Fe}^{2+}$ esetében, viszont a $\mathrm{Co}^{2+} 13 \%-\mathrm{kal}, \mathrm{a} \mathrm{Mn}^{2+}$ $30 \%$-kal növelte az enzimaktivitást $50 \mu \mathrm{M}$ koncentrációban alkalmazva. $\mathrm{Zn}^{2+}$ és $\mathrm{Cu}^{2+}$ ionok esetében mutatkozott gátló hatás. A táblázat alapján általánosan is elmondható, hogy a $\mathrm{Zn}^{2+}$ és $\mathrm{Cu}^{2+}$ ionok mind a növényi, mind a különböző mikroorganizmusokból származó fitáz enzimek esetén gátlólag hatottak az enzim müködésére. Már 0,5 $\mathrm{mM}$ koncentrációban alkalmazva a $\mathrm{Zn}^{2+}$ és $\mathrm{Cu}^{2+}$ ionokat mintegy $50 \%$ aktivitás csökkenést okoztak a $S$. castelli fitáza esetén, $5 \mathrm{mM-os}$ koncentrációban pedig erősen gátolták az enzim müködését (SEGUEILHA et al. 1992). A Bacillus 
$s p$. fitáza erősen gátlódott az EDTA, $\mathrm{Cd}^{2+}$ és $\mathrm{Mn}^{2+}$ jelenlétében (KIM et al. 1998), míg a gomba fitáz aktivitása EDTA jelenlétében növekedett (WYSS et al. 1999a). Közepesen gátlódott a Bacillus $s p$. enzime a $\mathrm{Hg}^{2+}, \mathrm{Mg}^{2+}, \mathrm{Ba}^{2+}$ és $\mathrm{Cu}^{2+}$ által, ezeken túlmenően az Aspergillus niger fitáza esetén a $\mathrm{Fe}^{2+}, \mathrm{Fe}^{3+}$ ionok további gátlást eredményeztek, ellenben a $\mathrm{Mg}^{2+}$ és $\mathrm{Ba}^{2+}$, serkentőleg hatottak az enzim müködésére 0,1 mM-os koncentrációban (SARIYSKA et al. 2005). A 7. táblázatban szereplő mikroorganizmusok és növények esetében azonban a $\mathrm{Mg}^{2+}$ kisebb-nagyobb mértékü gátlást okozott, de jelenlétében a különböző eredetü enzimek egyike sem vált hatékonyabbá.

A $\mathrm{Ca}^{2+}$ fontos szerepet játszik a szerkezet kialakításában, azonban nem minden fitáz típus igényli a jelenlétét. A hisztidinsavas foszfatázokra általában gátló hatást fejtenek ki. A 8. táblázatban különböző $A$. niger törzseknél a Ca-ionok fitázra gyakorolt hatásait foglaltam össze. Jól látható, hogy 0,1-5 mM koncentrációban alkalmazva nem igazán befolyásolja az enzim müködését, esetleg mérsékelt 10 \% körüli aktivitás növekedés mérhető. Megfigyelhető az is, hogy a koncentráció is befolyásolja a hatást, $200 \mathrm{mM}$ koncentráció alkalmazásával már jelentős gátlást figyelhetünk meg az A. niger ATCC 9142 enzim müködése tekintetében. A. ficuum esetén a $\mathrm{Ca}^{2+}$ nem befolyásolta az enzim müködését, (SARIYSKA et al. 2005) ahogy az A. fumigatus és a R. oligosporus (CASEY \& WALSH 2004) eredetü hisztidinsavas foszfatázra is gátló hatású a $\mathrm{Ca}^{2+}$, szemben egy $\beta$ propeller fitázzal - Bacillus subtilis, Bacillus amyloliquefaciens - melynél a $\mathrm{Ca}^{2+}$ elengedhetetlen az aktív konformáció kialakításához (WYSS et al. 1999a., KEROVUO et al. 2000). Termofil fonalas gombák esetén a fémionok nagymértékü változást nem okoznak az enzim aktivitásában. A T. lanuginosus fitáz enzimének müködését a $\mathrm{Ba}^{2+}$ és $\mathrm{Cu}^{2+}$ ionok csökkentik (GULATI et al. 2007b), míg a Sporotrichum thermophile fitáz enzim müködésére a vizsgált ionok enyhe gátló hatást fejtettek ki a $\mathrm{Mg}^{2+}$ kivételével. A fémionok feltehetően oldhatatlan komplexet képeznek a fitinsavval a reakcióelegyben, csökkentve az enzim számára a hozzáférhető szubsztrát mennyiségét (KONIETZNY \& GREINER 2002).

\section{8. táblázat A kalcium-ion hatása különböző Aspergillus niger törzsek aktivitására}

\begin{tabular}{|c|c|c|}
\hline $\begin{array}{c}\text { Aspergillus niger } \\
\text { törzsek }\end{array}$ & Kalcium ion hatása az aktivitásra & Hivatkozás \\
\hline A. niger 11T53A9 & 0,1 és $1 \mathrm{mM}$ koncentrációban nincs hatása & GREINER et al. 2009. \\
\hline A. niger (Natuphos) & 0,1 és $1 \mathrm{mM}$ koncentrációban nincs hatása & WYSS et al. 1999a. \\
\hline A. niger 307 & 0,1 mM koncentráció, $7 \%$-os növekedés & SARIYSKA et al. 2005 \\
\hline A. niger ATCC 9142 & 200 mM koncentráció, 32 \%-os gátlás & CASEY \& WALSH 2003 \\
\hline A. niger NCIM 563 & 5 mM koncentrációban enyhe növekedés & BHAVSAR et al. 2011 \\
\hline A. niger NCIM 563 & $1 \mathrm{mM}$ koncentrációban serkentő hatás & SONI \& KHIRE 2007 \\
\hline A. niger & 0,2 mM koncentráció, $12 \%$-os növekedés & DVORÁKOVÁ et al. 1997 \\
\hline
\end{tabular}


A fitátok enzimes hidrolízisét $\mathrm{pH}=7$ értéken az ásványi anyagok a következő sorrendben gátolják: $\mathrm{Zn}^{2+}>>\mathrm{Fe}^{2+}>\mathrm{Mn}^{2+}>\mathrm{Fe}^{3+}>\mathrm{Ca}^{2+}>\mathrm{Mg}^{2+}$. E gátló mechanizmus összefügg a komplex stabilitásával, az oldat pH-jával, valamint a fitát és az ásványi anyag arányával (ANGEL et al. 2002). A fémionok mellett a szerves savak is akadályozhatják, módosíthatják az enzimmüködést. TANG és munkatársai (2006) által végzett kísérletek azt mutatják, hogy a fenilglioxál, a molibdát, a citrát, az oxalát és a malát mind a gomba, a baktérium és a növényi eredetű fitázra is gátló hatással vannak.

\subsubsection{A fitáz enzim biotechnológiai hasznosíthatósága}

A fitáz enzim hasznosíthatósága széleskörü. A fitinsavat hidrolizálja, melynek eredményeképp javul az emészthetőség és a tápanyagok hasznosulása mind humán viszonylatban, mind a takarmányozás során. Szerepet játszik a környezet foszfor szennyezése elleni küzdelemben. A fitinsav részleges enzimes lebontása során keletkező mioinozit-foszfátok (tri-, tetra-, pentafoszfátok) számos jótékony, egészségmegörző hatással rendelkeznek, például a rák elleni védelemben is felismerték jelentőségét. Az alábbiakban bemutatom a fitáz enzim alkalmazási lehetőségeit.

\subsubsection{A fitáz alkalmazása a takarmányozásban}

A fitáz enzim biotechnológiai jelentőségei közül a legismertebb és általánosan elterjedt a takarmányozásban való alkalmazása. Enzimeket a takarmányozás során különböző célból alkalmaznak:

1. A takarmánynövényekben megtalálható antinutritív anyagok lebontása végett. Ezek nagy részét az állat saját enzimrendszerével nem tudja lebontani, ezért fogyasztásuk emésztési és felszívódási problémákat eredményez.

2. A keményítő, fehérjék és ásványi anyagok hasznosulását növeli, melyek vagy rostok közé vannak ágyazva, így nem elérhető az állat saját enzimei számára, vagy kémiailag kötöttek (pl. fitinsav), ezért az állat számára emészthetetlenek.

3. Hozzáadott enzim adagolásával a nyersanyag speciális kémiai kötései bonthatók, - melyet az állat saját enzimeivel nem képes -, ezáltal a fontos tápanyagok elérhetővé és hasznosíthatóvá válnak.

4. Fiatal állatok esetén a többlet enzim bevitel elönyös, hiszen még fejletlen a bélrendszerük és az endogén enzimeik termelése nem kielégítő (SHEPPY 2001).

Általánosságban ezen okok indokolják a fitáz enzim alkalmazását a nagyüzemi állattartásban. Biotechnológiai fejlesztéséhez és a takarmányozásban való elterjedéséhez kétségtelenül az állati ürülék nagy foszfor szintjének környezeti hatása miatti aggodalom vezetett. A takarmányban 
található fitátok lebontása a kérődző állatokban, a gyomrukban lévő mikrobiota segítségével történik. Az egygyomrú állatok, mint a sertések, baromfik, halak, valamint az ember emésztőrendszeréből is hiányzik, vagy nagyon csekély mértékü a fitáz aktivitás. A fitát lebontásának hiányában mind a foszfor, mind a fitát kelátképző tulajdonságának következtében megkötött tápanyagok felszívódása korlátozott. Az állatok számára a megfelelő foszfor bevitel érdekében a takarmányhoz szervetlen foszfort adagolnak, mely drága és nem-megújuló takarmány kiegészítő (LEI \& PORRES 2003). Mindemellett a fitáthoz kötött, valamint a nem hasznosult foszfor hígtrágyába kerülve a környezet foszfor terhelését növeli. A fitáz alkalmazásának célja tehát a nagyüzemi állattartásban a takarmányozásra használt gabonafélékben lévő fitáthoz kötött foszfor felszabadítása, valamint az ásványi anyagok és aminosavak hasznosulásának növelése, ezáltal a könyezetbe kibocsátott foszfor mennyiségének mérséklése.

Az Európai Közösség Bizottságának 243/2007/EK rendelete a genetikailag módosított Aspergillus niger CBS 101.672 törzs eredetü 3-fitáz (Natuphos) enzimkészítmény takarmányadalékanyagként való használatát 2007-ben engedélyezte. Az enzimet elválasztott malacok, hízósertések és csirkék esetében alkalmazzák, olyan takarmányok esetén, melyek több mint 0,23\% fitin-kötésben lévő foszfort tartalmaznak. Az enzimkészítmény nincs káros hatással az állatok és az ember egészségére vagy a környezetre. Ajánlott adagolása, a teljes értékü takarmány minden kilogrammjában $500 \mathrm{U}$.

A takarmányozásban használt enzimeknek számos követelménynek kell megfelelniük. Az emésztőrendszerben való hatékony működéséhez elengendhetetlen, hogy az enzim pH optimuma savas tartományban legyen, valamint a gyomorban ellenálljon a fehérjebontó enzimeknek (pepszin, tripszin). Mivel takarmányként pelletált formában kerül az állatok elé, szükséges a $65-80^{\circ} \mathrm{C}-\mathrm{os}$ pelletálási hőmérséklet jelentős aktivitás csökkenés nélküli túlélése. Megfelelő stabilitás szükséges szobahőmérsékleten is, hogy hosszú távú tárolás vagy szállítás során is megőrizze aktivitását az enzim (SINGH \& SATYANARAYANA 2011).

A mikrobiális fitáz enzim takarmány-kiegészítőként való alkalmazásának hatásai ma már jól dokumentáltak. Az etetési kísérletek is bizonyítják a takarmányhoz adagolt fitáz hatékonyságát: a sertés és baromfi tartás során az exogén fitáz adagolása javítja a fitát-foszfor és a fitáthoz kötött ásványi anyagok hasznosulását, ezáltal csökken a foszfor pótlás, valamint a trágyakezelés költsége is (KNOWLTON et al. 2004, SELLE \& RAVINDRAN 2007). Broiler csirkék esetén fitáz alkalmazásával nemcsak a foszfor kiürülése csökkent szignifikánsan, hanem a kiválasztott aminosavak, kalcium, nátrium, foszfor és szialinsav mennyisége is (COWIESON et al. 2004), valamint javult a tojáshozam (UM \& PAIK 1999). Sertéseknél a takarmány fitázzal történő kiegészítésével jobban növekedett a malacok csont tömege, a hamu százalék, a hamu súlya, a Ca és $\mathrm{P}$ mennyisége, mint az alacsony foszfor tartalmú enzim pótlás nélküli étrend alkalmazásával 
(YOUNG et al. 1993).

A csökkenő halliszt termelés következtében a vízi kultúrákban is elkerülhetetlen a növényi alapú takarmányok alkalmazása, melynél szintén problémaként kezelendő a magas fitinsav tartalom. Éppen ezért a fitáz enzim alkalmazása a halgazdaságokban a költség-hatékony takarmányozás és a környezetvédelmi problémák megoldásának igényével együtt bővül és növekvő tendenciát mutat, azonban összehasonlítva a nagyüzemi sertés és baromfi takarmányozással, még kezdeti fázisban van (CAO et al. 2007). Mivel a fitáz müködését is befolyásolja a pH és a hömérséklet, a számos izolált és jellemzett enzim közül meg kell találni azt, melynek tulajdonságai, stabilitása a legmegfelelőbb a halak emésztő-szervrendszerében a hatékony müködéshez. LIEBERT és PORTZ (2007) növényi alapú haleledel (szójaliszt, kukorica, búza, búza glutén) fitinsav tartalmának alakulását, valamint emésztésre gyakorolt hatását vizsgálták két különöbző fitáz enzimet alkalmazva kiegészítésként. Megállapították, hogy a fitáz enzimek alkalmazásával szignifikánsan növekedett a fehérjék, a kalcium és a foszfor emészthetősége a nílusi tilápia halak esetében, ezzel egyidejüleg csökkent a környezetbe kiválasztott foszfor mennyisége is. Ugyanakkor eredményeik azt is bizonyítják, hogy a mikrobiális fitáz enzim eredetétől függően a fitát degradáció különbözőképpen megy végbe az emésztőrendszerben, melyet az enzim eredetén túl befolyásol a halak fajtája is. Szintén bizonyították, hogy az enzimek eltérő hatékonysága nem kompenzálható a tilápiáknak javasolt tartományon belüli enzim mennyiség változtatásával.

Indiai hering (Chanos chanos) takarmányában lévő halliszt szójalisztre cserélhető fitáz enzimes kiegészítéssel, mely kiküszöböli a csupán szójaliszt alkalmazásával csökkent súlygyarapodást (HASSAN et al. 2009). A szivárványos pisztránggal (Oncorhynchus mykiss) etetett árpa, repce dara, búza és búzadara emészthetősége is szignifikánsan javult, s növekedett a $\mathrm{Ca}, \mathrm{Mg}$, Mn és a teljes, valamint a fitát-foszfor hasznosulás az enzim alkalmazásával (CHENG \& HARDY 2002).

A takarmányokban jelenlévő fitázok alkalmazhatóságát korlátozza, hogy a fitáz mennyisége még egy takarmányon belül is nagyon változó. Néhány gabonaféle, mint a rozs, tritikálé, búza és árpa gazdag fitázban, míg más takarmányok, mint a kukorica és az olajos magvak alacsony fitáz tartalmúak, vagy nincs fitáz aktivitásuk (EECKHOUT \& DE PAEPE 1994, HAEFNER et al. 2005). Figyelembe kell venni azt is, hogy a gabona eredetü fitáz hatásfoka csak 40\%-a az Aspergillus eredetü fitázénak (ZIMMERMANN et al. 2002).

A fitáz alkalmazásának egyetlen megszorító tényezője, az előállításával és alkalmazásával járó költségek. Azokban az országokban, ahol előírásokkal szabályozzák a tápanyag gazdálkodást, a túlzott foszfor kibocsátás miatti büntetés elkerülése ellensúlyozni tudja az enzim kiegészítéssel járó költségeket (AFINAH et al. 2010). A fitáz alkalmazása összességében a takarmányozás költségének mérséklődését is maga után vonja (BARUAH et al. 2004). 


\subsubsection{Alkalmazás a környezetvédelemben}

A felszíni vizek különböző eredetű szennyeződései világszerte komoly problémát okoznak. A különböző kormányok és a környezetvédők különös figyelmet fordítanak és egyre szigorúbb korlátozásokat vezetnek be azokon a területeken és iparágakban, ahol a környező ökoszisztémába mezőgazdasági kibocsátás történhet. A szennyező komponensek közül különös figyelmet érdemel a természetes vízi környezetbe jutó nitrogén és foszfor, melyek eutrofizációs szempontból alapvetően fontos összetevőnek tekinthetők. Különösen az oldott reaktív foszfor, ami a víz minősége szempontjából a legmeghatározóbb tényező. A takarmányozás során az állatok szükségletét meghaladó foszfor kiegészítés megnöveli a kiürülés mértékét a hígtrágyába és a felesleges mennyiség a talajból a tavakba, folyókba és tengerekbe kerül, hosszú távon eutrofizációt okozva. A megnövekedett foszfor tartalom a vízben ugyanis fokozza a fitoplanktonok növekedését. A vízbe jutott foszfor minden kg-ja kb. $100 \mathrm{~kg}$ tömegü fitoplankton képződéséhez vezet (FEKETE et al. 1991). A mélyebb rétegekben fokozódik az anaerob anyagcsere, kén-hidrogén, ammónia, metán és más vegyületek keletkeznek. Megbomlik az oxidációs-redukciós folyamatok egyensúlya és oxigénhiány lép fel, ami végső soron a vízi élet pusztulását okozhatja (CAO et al. 2007). Cianobaktériumok (Anabaena, Aphanizomenon, Oscillatoria), kovasavas algák (Asterionella, Melosira), habképző algák (Phaeocystic pichetii) és toxikus algák (Dinophysis, Gonyaulux) szaporodnak el, melyek egyáltalán nem kívánatosak, s ártalmasak lehetnek mind a haszonállatokra, mind az emberi szervezetre.

További környezetvédelmi következmény, hogy a globális foszfor készletek felélése a jövőben szervetlen foszfor hiány kialakulásához vezethet, figyelembe véve, hogy a Föld teljes sertésállománya 400-450 millió tonna takarmányt fogyaszt évente, amely a foszfor igényt illetően egyenlő értékű 7 millió tonna kalcium-foszfáttal (SELLE \& RAVINDRAN 2007). Mikrobiális fitáz enzimkészítmények takarmányozásban való alkalmazása jelentősen befolyásolja a környezet terhelés mértékét, hiszen csökken a talaj és a vízkészletek foszfor szennyezettsége, valamint az ásványi foszfor lelőhelyek kimerülésének veszélye.

\subsubsection{Alkalmazás az emberi táplálkozásban}

A fitáz enzim emberi táplálkozásban való alkalmazása elsősorban a fitinsav okozta hiánybetegségek kialakulásának mérséklésére szolgálhat. Az egyoldalú növényi nyersanyagra épülő étrend többek között krónikus vashiányhoz, valamint egyéb anyagcsere és fejlődésbeli zavarokhoz vezethet. Néhány élelmiszerfeldolgozási eljárás, mint a főzés, fermentáció és áztatás is számottevően csökkenti a hüvelyesekben, gabonákban levő fitinsavat. Azonban az élelmiszerek fitinsav tartalmának csökkentésére leghatékonyabb módszer az enzimes hidrolízis (HAEFNER et al. 2005). 
HAROS és munkatársai (2001) a fitáz enzim lehetséges felhasználását vizsgálták a kenyérgyártás során. Különböző mennyiségű gomba eredetű fitázt adagoltak teljes kiőrlésű lisztből készült kenyérhez és azt tapasztalták, hogy a fitáz kitünő hatással volt a kenyér előállítására. Kísérletük legfőbb eredménye, hogy a kenyértészta $\mathrm{pH}$ változása nélkül lerövidül a fermentáció, amely érinti mind a kovászérést, mind a tésztakelesztés müveleteit. A kenyér térfogatának és a kenyér bélzetének javulását, finomodását is megfigyelték.

Kísérletek folynak Lactobacillus és Bifidobacterium fajok sütőipari alkalmazására vonatkozóan is, elsősorban a teljes kiőrlésü kenyerek esetén (PALACIOS et al. 2008 a,b,c). Az így készült kenyerek technológiai minősége hasonló a Lactobacillus nélküli kenyerekéhez, a mioinozitfoszfátok mennyisége azonban jelentősen csökkent, de a kenyérbélzet kisebb foszforiláltságú mioinozit-foszfátokat is tartalmazott (PALACIOS et al. 2008a). Termékfejlesztési céllal létrehozható olyan fermentált gabona alapú termék, mellyel azon fogyasztók számára is biztosítható jótékony hatású, probiotikus élelmiszer, akik az általánosan elterjedt tejalapú probiotikus termékeket nem fogyaszthatják, (tejfehérje allergiában szenvedők) vagy meggyőződésből nem fogyasztják (pl. vegetáriánusok). Összességében megállapítható, hogy a magas fitátbontó aktivitással és jó tulajdonságokkal rendelkező starter kultúrák alkalmazhatók a teljes kiőrlésü kenyerek, illetve egyéb gabona alapú termékek gyártási folyamatában.

A lebontás során a maradék foszfor csoportok számától és elhelyezkedésétől függően különböző fiziológiai tulajdonsággal bíró mioinozit-foszfátok alakulnak ki. Ezek szerepe a rákmegelőzésben jelentős, bár a mai napig kérdés, hogy a fitinsav vagy a lebontása során keletkező mioinozit-foszfátok okozzák-e a jótékony hatást (KUMAR et al. 2010).

\subsubsection{Talajjavítás}

A fitáz enzim talajjavításban való alkalmazhatóságának alapja, hogy a mezőgazdasági termelésre alkalmas területek világszerte foszfor szegények. Bár egyes helyeken a fitinsav és származékai a teljes szerves foszfor mennyiség több mint $50 \%$-át adják a talajban, mivel a növények nem termelnek extracelluláris fitázt, a fitinsavból nyerhető foszfor nem elérhető számukra. A foszfort a gyökérszőrökön keresztül veszik fel a növények, ezért génexpresszióval létrehozott transzgénikus növény gyökeréből érdemes a fitáz enzim kiválasztása a rizoszférába, ahol a fitát is található. Ennek megvalósítására GEORGE és munkatársai (2005) Arabidopsis thaliana gyökerébe

A. niger eredetű fitáz gént fejeztettek ki, és vizsgálták az enzim müködését. Megállapították, hogy a talaj pH-ja nagyon meghatározó az aktivitás tekintetében, valamint, hogy a fitáz gyors megkötődése a talajban akadályozhatja a szubsztráttal való találkozást. FINDENEGG \& NELEMANS (1993) a talajok fitáz kezelésével vizsgálta fitinsavból felszabadított szervetlen foszfor hatását a kukorica 
növények termesztésénél. A tapasztalt növekedés serkentő hatást a fitin lebontásnak tulajdonították. SINGH \& SATYANARAYANA (2010) Sporotrichum thermophile fitáz enzimét vagy a termofil gomba spóráit alkalmazták fitát bontására búza termesztése során. A kiegészítés hatására a szárazanyag és a szervetlen foszfát tartalom növekedett a növényben, sőt a fitáz mennyiségének emelésével (max. 20 U növényenként) további növekedést tapasztaltak.

\subsubsection{Transzgénikus növények, állatok}

A mikrobiális fitáz elöállítás meglehetősen költséges, éppen ezért a heterogén fitáz kifejeztetése növényekben, valamint állatokban hatékony módja lehet a foszfor és egyéb ásványi anyagok hasznosulásának növelésére az élő szervezetekben. E módszerrel szintúgy csökkenthetők az állattakarmányozás költségei, továbbá jelentősen mérsékelhető a környezet foszfor terhelése is. Számos kutatást végeztek már különböző növények alkalmazásával melyekbe rekombináns fitáz gént ültettek be: gomba fitáz géneket, mint például az Aspergillus niger phyA génjét sikeresen expresszálták dohányban (VERWOERD et al. 1995), búzában (BRINCH-PEDERSEN et al. 2000), rizsben (LIU et al. 2006) és repcében (HESZKY et al. 2005). LI és munkatársai (1997) szójában expresszálták

A. niger NRRL 3135 phyA génjét. Nemcsak gomba fitázokat termeltethetnek növényekben, pl. $E$. coli appA génjét is sikeresen expresszáltatták rizsben (HONG et al. 2004). A csírázó magvakban a fitáz aktivitás 60-szor nagyobb értéket ért el ez utóbbi esetben, mint a nem transzformált növényben. Egerekbe is beültették az E. coli appA fitáz génjét GOLOVAN és munkatársai (2001a), s a transzgénikus egérhez hasonlóan, olyan transzgénikus sertést is sikerült létrehozni, melynek közvetlenül a nyálmirigyébe ültettek növényi eredetű fitáz gént (GOLOVAN et al. 2001b), így sem szervetlen foszfort, sem enzimkészítményt nem kell a takarmányba keverni és a foszfor kibocsátás is $75 \%$-kal csökkent. Szintén sertésben fejeztették ki az E. coli appA fitáz gént, így az enzimet a nyálba kiválasztva a fitinsav bontásával $60 \%$-os csökkenést értek el a foszfor ürítés tekintetében (FORSBERG et al. 2003). Transzgénikus növények, közvetlenül takarmányként vagy bioreaktorként alkalmazhatók fitáz enzim előállítására. 


\section{CÉLKITÜZÉSEK}

A fitáz enzim alkalmazása a monogasztrikus állatok nagyüzemi állattartásában már világszerte elterjedt. A humán táplálkozásban is egyre nagyobb szerepet kaphat: egyrészt a fitinsavhoz kötött táplálkozás-élettanilag nélkülözhetetlen ásványi anyagok felszabadítása révén, másrészt a fitinsav részleges hidrolízisével keletkező mioinozit-foszfátok egészségmegőrzésben kifejtett jótékony hatása miatt.

A fitáz enzim széleskörü előfordulása lehetőséget nyújt különböző eredetű enzimek előállítására. A növényi és állati eredet mellett, leghatékonyabban fonalas gombák fermentációjával állítható elő.

A termelő mikroorganizmustól függően az enzim hatásmechanizmusa, optimális müködési körülményei, szubsztrát specifitása, stabilitása eltérő lehet, melyek ismerete feltétele az ipari alkalmazhatóságának. Mindezen célok elérése érdekében különböző fonalas gomba eredetü enzimfermentációk megvalósítását és összehasonlítását terveztem, melyekhez a mezofil Aspergillus és a termofil Thermomyces lanuginosus fonalas gombákat választottam.

A különböző eredetű fitáz enzimek előállításának és jellemzésének megvalósítása céljából a következő részfeladatokat tüztem ki:

1. Thermomyces lanuginosus és Aspergillus törzsek szelektálása fitáz enzim termelésre

2. Az enzim fermentáció fejlesztése

2.1 Inokulálási technológia

2.2 Tápközeg összetétel optimálás

2.2.1. Szén és nitrogén forrás minőségi és mennyiségi beállítása

2.2.2. Felületaktív anyagok hatásának vizsgálata

3. Az enzimek homogenitásig történő tisztítása

4. Az előállított fitáz enzimek jellemzése

4.1 Molekulatömeg

4.2 Optimális müködési paraméterek

4.3 Fémionok hatásának vizsgálata az enzimaktivitásra

4.4 Kinetikai paraméterek meghatározása 


\section{ANYAGOK ÉS MÓDSZEREK}

\subsection{Alkalmazott mikrobiológiai módszerek}

\subsubsection{Felhasznált mikroorganizmusok}

A fitáz enzim előállítására különböző törzsgyüjteményekből származó Aspergillus és Thermomyces lanuginosus fonalas gomba törzseket használtam (9. táblázat). Az alábbiakban felsorolt és alkalmazott Aspergillus törzsek a Mezőgazdasági és Ipari Mikroorganizmusok Nemzeti Gyüjteményéből származtak:

9. táblázat Az alkalmazott Aspergillus és Thermomyces törzsek

\begin{tabular}{|c|c|}
\hline Aspergillus fajok és törzsek & Thermomyces lanuginosus törzsek \\
\hline Aspergillus awamori NCAIM F 00030 & Thermomyces lanuginosus \\
\hline Aspergillus niger NCAIM F 00071 & ATCC 16455 \\
\hline NCAIM F 00632 & ATCC 28083 \\
\hline NCAIM F 00671 & ATCC 34626 \\
\hline NCAIM F 00714 & ATCC 36350 \\
\hline NCAIM F 00720 & ATCC 38905 \\
\hline NCAIM F 00722 & ATCC 44008 \\
\hline NCAIM F 00735 & ATCC 46882 \\
\hline NCAIM F 00770 & ATCC 84400 \\
\hline NCAIM F 00892 & CBS 218.34 \\
\hline Aspergillus wentii NCAIM F 00167 & CBS 288.54 \\
\hline & CBS $395.62 b$ \\
\hline & IMI 096218 \\
\hline & IMI 158749 \\
\hline & DSM 5826 \\
\hline
\end{tabular}

ATCC: (American Type Culture Collections)

$C B S$ : (Centraalbureau voor Schimmelculture)

DSM: (Deutsche Sammlung von Microorganismen und Zellkulturen GmbH)

IMI: (International Mycological Institute)

NCAIM: (National Collection of Agricultural and Industrial Microorganisms)

\subsubsection{Alkalmazott tápközegek összetétele}

Törzsfenntartáshoz alkalmazott táptalaj

Burgonya-glükóz agar

Potato dextrose agar (Merck)

Desztillált víz
$39 \mathrm{~g}$

$1000 \mathrm{ml}-\mathrm{re}$

Sterilezés $121^{\circ} \mathrm{C}$-on 15 percig. 


\section{Inokulum tápközeg}

Burgonya-glükóz tápleves (A. niger)

Potato dextrose broth (Sigma)

Desztillált víz

1000 ml-re

Sterilezés $121^{\circ} \mathrm{C}$-on 15 percig.

Glükóz-aszparagin tápközeg (T. lanuginosus)

$\begin{array}{lc}\text { Glükóz } & 20 \mathrm{~g} \\ \text { L-aszparagin } & 4,5 \mathrm{~g} \\ \mathrm{KH}_{2} \mathrm{PO}_{4} & 3 \mathrm{~g} \\ \mathrm{~K}_{2} \mathrm{HPO}_{4} & 2 \mathrm{~g} \\ \mathrm{MgSO}_{4} * 7 \mathrm{H}_{2} \mathrm{O} & 0,5 \mathrm{~g} \\ \text { Vogel féle nyomelemoldat } & 1 \mathrm{ml} \\ \text { Desztillált víz } & 1000 \mathrm{ml} \text {-re }\end{array}$

Sterilezés $121{ }^{\circ} \mathrm{C}$-on 15 percig.

Vogel-féle nyomelem oldat

$\begin{array}{lc}\text { Citromsav } * \mathrm{H}_{2} \mathrm{O} & 5 \mathrm{~g} \\ \mathrm{ZnSO}_{4} * 7 \mathrm{H}_{2} \mathrm{O} & 5 \mathrm{~g} \\ \mathrm{Fe}\left(\mathrm{NH}_{4}\right)_{2}\left(\mathrm{SO}_{4}\right)_{2} * 6 \mathrm{H}_{2} \mathrm{O} & 1 \mathrm{~g} \\ \mathrm{CuSO}_{4} * 5 \mathrm{H}_{2} \mathrm{O} & 0,25 \mathrm{~g} \\ \mathrm{MnSO}_{4} * \mathrm{H}_{2} \mathrm{O} & 0,05 \mathrm{~g} \\ \mathrm{H}_{3} \mathrm{BO}_{3}(\text { anhidrid }) & 0,05 \mathrm{~g} \\ \mathrm{Na}_{2} \mathrm{MoO}_{4} * 2 \mathrm{H}_{2} \mathrm{O} & 0,05 \mathrm{~g} \\ \text { Desztillált vízzel } & 100 \mathrm{ml}-\mathrm{re}\end{array}$

Fermentációs tápközegek

Rizslisztes alaptápközeg:

$\begin{array}{lc}\text { Rizsliszt } & 50 \mathrm{~g} \\ \mathrm{MgSO}_{4} * 7 \mathrm{H}_{2} \mathrm{O} & 0,5 \mathrm{~g} \\ \mathrm{KCl} & 0,5 \mathrm{~g} \\ \mathrm{FeSO}_{4} & 0,1 \mathrm{~g} \\ \mathrm{NaNO}_{3} & 8,6 \mathrm{~g} \\ \text { Desztillált víz } & 1000 \mathrm{ml}-\mathrm{re}\end{array}$

A tápközeg pH-ja 5,6

Sterilezés $121^{\circ} \mathrm{C}$-on 15 percig. 


\section{Kukoricalisztes tápközeg:}

$\begin{array}{lc}\text { Kukoricaliszt } & 30 \mathrm{~g} \\ \text { Glükóz } & 20 \mathrm{~g} \\ \mathrm{MgSO}_{4} * 7 \mathrm{H}_{2} \mathrm{O} & 0,5 \mathrm{~g} \\ \mathrm{KCl} & 0,5 \mathrm{~g} \\ \mathrm{FeSO}_{4} & 0,1 \mathrm{~g} \\ \mathrm{NaNO}_{3} & 8,6 \mathrm{~g} \\ \text { Desztillált vízzel } & 1000 \mathrm{ml}-\mathrm{re}\end{array}$

A tápközeg pH-ja 6,5

Sterilezés $121^{\circ} \mathrm{C}$-on 15 percig.

\subsubsection{Tenyésztési módszerek, körülmények}

\subsubsection{Törzsfenntartás}

A törzsfenntartás burgonya-glükóz agaron történt. Átoltás után a Thermomyces lanuginosus törzseket 8-10 napig $47^{\circ} \mathrm{C}$-on tenyésztettem Petri-csészében, míg az Aspergillus törzseket $28^{\circ} \mathrm{C}$-on inkubáltam ferde agaron, majd $4^{\circ} \mathrm{C}$-on hütőszekrényben tároltam.

\subsubsection{Inokulum tenyészet készítése}

100 ml-es Erlenmeyer lombikokban, 100 ml töltöttség mellett burgonya-glükóz táplevesben szaporítottam fel az Aspergillus törzseket. A ferde agaros tenyészetröl a konídiumokat $5 \mathrm{ml}$ 0,01\%os TritonX-100 felületaktív anyag oldatával mostam le. A konídium szuszpenzió koncentrációját Bürker-kamrában történő számolással állapítottam meg, és $10^{5}$ konídium $/ \mathrm{ml}$ koncentrációra indítottam a szaporítást. A tenyésztés Gallenkamp típusú rázóinkubátorban $28{ }^{\circ} \mathrm{C}$-on, 220 fordulat/perc rázósebességen, 24-48 órán át történt.

Thermomyces lanuginosus esetén a Petri-csészén kinőtt érett tenyészetekből kivágtam egy

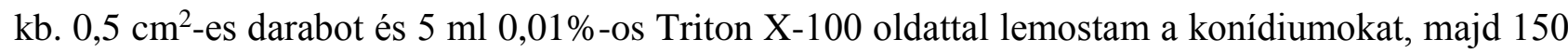
$\mathrm{ml}$ inokulum tápközeget tartalmazó $500 \mathrm{ml}$-es Erlenmeyer lombikba vittem át. A tenyésztés Gallenkamp típusú rázóinkubátorban $47{ }^{\circ} \mathrm{C}$-on 220 fordulat/perc rázósebességen, 24-48 óráig történt.

\subsubsection{Fermentáció}

A fitáz enzim előállítását rázott lombikos fermentációval 500 illetve 1000 ml-es Erlenmeyer lombikokban, $150 \mathrm{ml}$ fermentációs tápközegekben végeztem. A tápközegeket a kísérleti tervnek megfelelő mennyiségü és korú inokulum tenyészettel indítottam, általában 5 tf\% 48 órás inokulumot alkalmaztam mindkét fonalas gomba esetén. A fermentáció a gombáknak megfelelő hömérsékleten (A. niger $28^{\circ} \mathrm{C}$, T. lanuginosus $47^{\circ} \mathrm{C}$ ) 220 fordulat/perc rázó sebességen 4-7 napig történt. Naponkénti mintavételezéssel, s az enzimaktivitás, valamint a pH mérésével követtem a 
fermentációs folyamatot. Az egyes kísérleti beállítások lehetőségeimhez mérten két párhuzamosban készültek, illetve adott kísérleteket többször is megismételtem.

\subsection{Alkalmazott oldatok, pufferek}

\subsubsection{Az enzimaktivitás mérésnél használt oldatok}

\section{Szubszatrátum}

8,40 g Na-fitátot $\left(\mathrm{C}_{6} \mathrm{H}_{6} \mathrm{Na}_{12} \mathrm{O}_{24} \mathrm{P}_{6}\right) 900 \mathrm{ml} \mathrm{Na}$-acetát ( $\left.\mathrm{pH}=5,5\right)$ pufferben feloldottam, 4 mólos ecetsav oldattal visszaállítottam a pH-t 5,5-re, majd 1000 ml-re egészítettem ki desztillált vízzel.

Na-acetát puffer $(\mathrm{pH}=5,5)$

1,76 g $96 \%$-os ecetsavat, 30,02 g Na-acetátot $\left(\mathrm{NaC}_{2} \mathrm{H}_{3} \mathrm{O}_{2} * 3 \mathrm{H}_{2} \mathrm{O}\right)$ és 0,47 g Ca-kloridot $\left(\mathrm{CaCl}_{2} * \mathrm{H}_{2} \mathrm{O}\right)$ bemértem, és feloldottam $900 \mathrm{ml}$ desztillált vízben, majd $96 \%$-os ecetsavval a pH-t 5,5-re állítottam, végül desztillált vízzel 1000 ml-re egészítettem ki.

\section{Leállító és színképzö reagens}

$250 \mathrm{ml}$ ammónium-molibdenát és $250 \mathrm{ml}$ ammónium-vanadát oldat elegyéhez $165 \mathrm{ml} 65$ \%os salétromsavat lassan hozzáadtam, ezt követően lehütöttem szobahőmérsékletüre, és desztillált vízzel 1000 ml-re egészítettem ki. A leállító és színképző reagens minden nap frissen készítendő.

\section{Ammónium-molibdenát oldat}

100 g ammónium-molibdenátot $\left(\mathrm{H}_{24} \mathrm{Mo}_{7} \mathrm{~N}_{6} \mathrm{O}_{24} * 4 \mathrm{H}_{2} \mathrm{O}\right)$ bemértem, feloldottam $900 \mathrm{ml}$ desztillált vízben, hozzáadtam $10 \mathrm{ml} 25 \%$-os ammónia oldatot majd desztillált vízzel $1000 \mathrm{ml}$-re egészítettem ki. Sötét helyen 1 hónapig tárolható.

\section{Ammónium-vanadát oldat}

2,35 g ammónium-vanadátot $\left(\mathrm{NH}_{4} \mathrm{VO}_{3}\right)$ feloldottam $400 \mathrm{ml} 60{ }^{\circ} \mathrm{C}$-os desztillált vízben. Hozzáadtam $20 \mathrm{ml} 65$ \%-os salétromsavat, majd miután lehütöttem szobahőmérsékletüre, desztillált vízzel 1000 ml-re egészítettem ki.

\subsubsection{Alkalmazott pufferek és reagensek (RAUEN 1964)}

Na-citrát/HCl puffer ( $\mathrm{pH}=1,5-3,5)$ :

A oldat: $0,1 \mathrm{M} \mathrm{Na-citrát}$

B oldat: $1 \mathrm{~N} \mathrm{HCl}$

Na-acetát puffer $(\mathrm{pH}=3,5-6,5)$ :

A oldat: $1 \mathrm{~N}$ ecetsav

B oldat: $1 \mathrm{~N} \mathrm{NaOH}$

TRIS-maleát/NaOH puffer ( $\mathrm{pH}=5,5-9,0)$ :

A oldat: 0,2 N TRIS-maleát (24,2 g TRIS és 23,2 g maleinsav $1000 \mathrm{ml}$ desztillált vízben)

B oldat: $0,2 \mathrm{~N} \mathrm{NaOH}$

A két oldat megfelelő arányú összemérése esetén, a kívánt pH értéket kapjuk 


\section{TRIS/HCl puffer $(\mathrm{pH}=7,2)$}

A oldat: $0,2 \mathrm{~N}$ TRIS $(250 \mathrm{ml})$

B oldat: $0,1 \mathrm{~N} \mathrm{HCl}(450 \mathrm{ml})$

A két oldatot összemérve és 1000 ml-re kiegészítve desztillált vízzel, a kívánt pH értéket kapjuk.

Polipuffer 74/HCl puffer ( $\mathrm{pH}=4,0)$

A polipuffer 74-et (Sigma-Aldrich) 1:8 arányban kell hígítani, a pH-ját $4 \mathrm{n} \mathrm{HCl}$ oldattal 4,0-ra állítani és 1000 ml-re desztillált vízzel kiegészíteni.

Imidazol/HCl puffer $(\mathrm{pH}=7,0)$

A oldat: $0,2 \mathrm{M}$ imidazol $\left(\mathrm{C}_{3} \mathrm{H}_{4} \mathrm{~N}_{2}\right)(250 \mathrm{ml})$

B oldat: $0,1 \mathrm{~N} \mathrm{HCl}(243 \mathrm{ml})$

A két oldatot összemérve és 1000 ml-re kiegészítve desztillált vízzel, a kívánt pH értéket kapjuk.

\section{Futtató puffer $(\mathrm{pH}=8,3)$}

3,03 g hidroximetil-aminometánt (TRIS), 14,4 g glicint és 1,0 g Na-dodecil-szulfátot (SDS) bemértem, majd desztillált vízben feloldottam és kiegészítettem 1000 ml-re.

\section{Coomassie festékoldat}

0,2 g Coomassie R-250-et bemértem, majd hozzáadtam $50 \mathrm{ml} 96 \%$ etanolt, $10 \mathrm{ml}$ $96 \%$-os ecetsavat és $50 \mathrm{ml}$ desztillált vizet.

\section{Mosóoldat elektroforézishez}

Bemértem $10 \mathrm{ml} \mathrm{96 \% -os} \mathrm{ecetsavat,} \mathrm{és} 40 \mathrm{ml} 96$ \%-os etanolt, majd desztillált vízzel $100 \mathrm{ml}$-re kiegészítettem.

\section{Színreagens}

A fehérjetartalom meghatározására (Bradford módszer) a Bio-Rad cég által gyártott terméket (Dye reagent) használtam az elöírásnak megfelelően, négyszeres hígításban.

\subsection{Analitikai módszerek}

\subsubsection{Enzimaktivitás meghatározásának módszere}

A fitáz enzim aktivitásának mérése ENGELEN és munkatársai (1994) által közölt módszer szerint történt, mely a Na-fitát szubsztrátumból felszabadult szervetlen foszfor mennyiségének meghatározásán alapul. Az ammónium-molibdenát jelenlétében a reakciótermék sárga színü komplexet képez, melynek mennyisége fotometriásan $415 \mathrm{~nm}$-en meghatározható.

Mivel a gomba eredetü fitáz enzimek extracellulárisak, ezért közvetlenül a fermentlé szürletéből mértem az enzim aktivitását. Szürőpapírral elválasztottam a biomasszát a fermentlétől, majd $1 \mathrm{ml} \mathrm{Na-fitát} \mathrm{szubsztrátumot}(\mathrm{pH}=5,5)$, - valamint a megfelelő vakpróbákat - az aktivitás mérés hőmérsékletén előinkubáltam 5 percig. Az enzimreakciókat 0,5 ml megfelelően hígított 
enzimoldat hozzáadásával indítottam, s 10 perces reakció idő után, 1 ml leállító és színképző reagens hozzáadásával állítottam le. Az enzimaktivitás, az abszorbancia és a $0-5 \mathrm{mM}$ foszfát koncentráció közötti lineáris összefüggés segítségével számítható a következő egyenlet szerint:

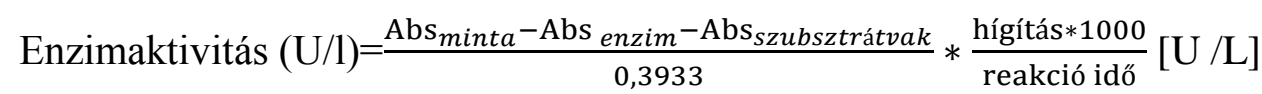

\section{Az enzimaktivitás definiálása:}

Egy fitáz egység (U) az az enzim mennyiség, ami Na-fitát szubsztrátumból $1 \mu$ mol szervetlen foszfátot szabadít fel 1 perc alatt, a reakció körülményei között.

\section{Enzimaktivitás mérése mikrotiter lemezen}

Az enzimtisztítás során a kromatográfiás oszlopról eluálódott nagyszámú fehérje frakcióból a fitáz aktivitás kimutatására miniatürizált mikrotiter lemezes módszert dolgoztam ki. Az enzimreakció során $25 \mu$ l fehérjeoldatot, $75 \mu$ desztillált vizet és $100 \mu \mathrm{l}$ Na-fitát szubsztrátumot pipettáztam a mikrotiter lemez celláiba, majd az adott mikroba aktivitás mérési módszerének megfelelő hőmérsékleten 30 percig tartó reakció után $50 \mu$ l leállító és színképző reagenst adtam hozzá. Az abszorbanciát 415 nm-en mikrotiter leolvasó segítségével mértem, majd az enzim aktivitását az abszorbancia és a foszfát koncentráció közötti lineáris összefüggés segítségével határoztam meg.

\subsection{Fehérje meghatározási módszerek}

\subsection{1 $280 \mathrm{~nm}$-en történő fényelnyelésen alapuló módszer}

Ezt a módszert az enzimtisztítás során az egyes frakciók fehérjetartalmának vizsgálata során alkalmaztam. Ebben az esetben nem a pontos fehérjekoncentrációt, hanem a frakciókban a hozzávetőleges mennyiséget kívántam meghatározni. Ultraibolya spektrofotometriával 280 nm-en, a fehérjék abszorpciós maximumán mértem az elnyelési értékeket.

\subsubsection{Bradford módszer}

Széles körben alkalmazott fehérjemérési módszer, mely festékkötődésen alapul. Elve, hogy a fehérje és a színező anyag kék színü komplexet hoz létre, mivel a festék az arginil- és lizil oldalláncokhoz kötődik. A komplex maximális abszorbanciája 595 nm-en mérhető. A meghatározáshoz a Bio-Rad cég által forgalmazott koncentrált színező reagenst használtam.

A mérés során a mintákból $10 \mu$ l-t pipettáztam be mikrotiter lemezbe és a fehérjeoldatokat 200 $\mu 1$ színező reagenssel reagáltattam, majd 10 perc múlva mikrotiterlemez leolvasóval megmértem az abszorbanciákat. A minta fehérje koncentrációjára az elnyelés mértékéből következtethetünk, ismert fehérjetartalmú oldat $(0,5 \mathrm{mg} / \mathrm{ml}$ BSA - Bovine Serum Albumin) felhasználásával. A módszer egyszerüen kivitelezhető és 1 és $1400 \mu \mathrm{g} / \mathrm{ml}$ közötti koncentráció tartományban alkalmazható. 


\subsubsection{Kromatográfiás módszerek}

Kromatográfiás módszerekhez azokat az elválasztás technikai eljárásokat soroljuk, amelyekben két fázis (álló és mozgó fázis) közötti megoszlás eredményeként választhatók el a különböző tulajdonságok alapján az egyes komponensek. A két fázis közötti anyagátadás alapulhat adszorpción, ionos kölcsönhatáson, diffúzión, oldékonyságon, vagy különleges kölcsönhatásokon. Fehérjék tisztításakor a fehérjék különböző tulajdonságait, eltérő méretét, alakját, töltését, hidrofobicitását használjuk ki.

Munkám során a fehérjék tisztítása, FPLC (Fast Performance Liquid Chromatography) berendezéshez csatlakoztatott (Pharmacia, Uppsala, Sweden) különböző kromatográfiás oszlopok alkalmazásával, $4{ }^{\circ} \mathrm{C}$-on történt.

Ioncserélö kromatográfia: az álló fázis különböző savas vagy bázikus funkciós csoportokat hordozó ioncserélő gyanta (savas v. bázikus csoportot tartalmaz), amelyen a mozgó fázis töltéssel rendelkező ionjai vagy molekulái között létrejövő kölcsönhatás alapján valósul meg az elválasztás.

\section{Alkalmazott töltetek (AMERSHAM BIOSCIENCES 2002, 2004)}

\section{Q-Sepharose}

kvaterner amin erős anion-cserélő töltet összes ionkapacitás: $0,18-0,25 \mathrm{mmol} / \mathrm{ml}$ gél mátrix típusa: 6\% keresztkötésủ agaróz maximális lineáris térfogatáram: $750 \mathrm{~cm} / \mathrm{h}$ pH stabilitás: 2-12

\section{DEAE-Sepharose CL-6B}

gyenge anioncserélő töltet funkcionális csoport: - $\mathrm{O}-\mathrm{CH}_{2} \mathrm{CH}_{2} \mathrm{~N}^{+} \mathrm{H}\left(\mathrm{CH}_{2} \mathrm{CH}_{3}\right)_{2}$ dietilaminoetil (DEAE) mátrix típusa: 6\% keresztkötésủ agaróz összes ionkapacitás: $0,13-0,17 \mathrm{mmol} / \mathrm{mL}$ gél ajánlott lineáris térfogatáram $50-400 \mathrm{~cm} / \mathrm{h}$ pH stabilitás: 2-9

Gélszürés: A szétválasztás a molekulák mérete szerint történik. A kromatográfiás oszlop töltete egy finom szemcsés, 10-300 $\mu \mathrm{m}$ átméröjü gömbökböl álló porózus, hidrofil gél. Egy adott pórus mérettartománnyal rendelkező tötlet esetén egyes molekulák méretüknél fogva nem férnek be a gélszemcsék belsejébe, ezért ezek gyorsan keresztül folynak az oszlopon, míg a kisméretú molekulák több-kevesebb időt gélszemcsék belsejében levő folyadék térben töltenek, ezért lassabban jutnak keresztül a kromatográfiás oszlopon. Az alkotók tehát molekulaméretük csökkenő sorrendjében távoznak. 
Alkalmazott töltetek és föbb jellemzöik

\section{Sephacryl S200 HR}

optimális molekulatömeg elválasztási tartomány: $5 * 10^{3}-2,5 * 10^{5} \mathrm{Da}$

mátrix típusa: keresztkötés allil dextrán és N,N'-metilén-bisz-akrilamid között

ajánlott lineáris térfogatáram: $10-35 \mathrm{~cm} / \mathrm{h}$

pH stabilitás: 3-11

átlagos részecske méret: $47 \mu \mathrm{m}$

Hidrofób kölcsönhatáson alapuló kromatográfia: A töltet apoláris, a mozgó fázis poláris. Az elválasztás a fehérjék és a töltet alkil oldalláncai közötti reverzibilis kölcsönhatáson alapul. Tömény sóoldatokban a poláros fehérjék oldhatósága romlik, ezért hajlamosak megkötődni az apoláris töltet felületén. A polaritás csökkenésével (csökkenő sógradiens) hidrofóbitásuknak megfelelő sorrendben deszorbeálódnak.

Alkalmazott töltet

\section{Phenyl Sepharose Fast Flow (high-sub)}

mátrix típusa: $6 \%$ keresztkötésú (térhálósított) agaróz

hidrofób reverz fázisú oldalláncok

maximális térfogatáram: $3-4 \mathrm{ml} /$ perc

maximális nyomás: 3 bar

kapacitás: $40 \mu \mathrm{mol}$ fehérje/ml gél

átlagos részecske méret: $90 \mu \mathrm{m}$

pH stabilitás: $3-13$

Kromatofókuszálás: Az elválasztás a fehérjék izoelektromos pontja alapján történik. A start pufferrel és az eluens pufferrel pH gradienst alakítunk ki. A fehérjék izoelektromos pontjuknál magasabb pH-n negatív töltésűvé válnak, és a töltet pozitív töltésű amin csoportjaihoz kötődnek. Amikor a pH a fehérje izoelektromos pontjára csökken, a fehérje molekula töltése semlegessé válik, aminek következtében leválik az oszlopról.

\section{Alkalmazott töltet}

\section{PBE 94}

polypuffer cserélő (polybuffer exchanger)

mátrix típusa: keresztkötésủ agaróz

ajánlott lineáris térfogatáram: $30-40 \mathrm{~cm} / \mathrm{h}$

pH stabilitás: 4-9

Elektroforézishez szükséges gélek összetétele

Elválasztó gél (10\%)

$30 \%$ akrilamid-bisz-akrilamid

$1,65 \mathrm{ml}$

$10 \%$ Na-dodecil-szulfát (SDS)

$50 \mu 1$

1,5 M Tris- $\mathrm{HCl} \mathrm{pH}=8,8$

$1,25 \mathrm{ml}$ 
Desztillált víz $\quad 2 \mathrm{ml}$

$10 \%$ ammónium-perszulfát (APS) oldat $50 \mu 1$

$\mathrm{N}, \mathrm{N}, \mathrm{N}, \mathrm{N}$ '-tetrametil-etilén-diamin (TEMED) oldat $\quad 5 \mu \mathrm{l}$

$\begin{array}{ll}\text { Gyüjtő gél (4,1 \%) } & \\ 30 \% \text { akrilamid-bisz-akrilamid } & 0,66 \mathrm{ml} \\ \text { desztillált víz } & 2,98 \mathrm{ml} \\ 0,5 \mathrm{M} \text { Tris- } \mathrm{HCl} \mathrm{pH}=6,8 & 1,25 \mathrm{ml} \\ 10 \% \text { APS oldat } & 50 \mu \mathrm{l} \\ 10 \% \text { SDS } & 50 \mu \mathrm{l} \\ \text { TEMED oldat } & 10 \mu \mathrm{l}\end{array}$




\section{EREDMÉNYEK ÉS ÉRTÉKELÉSÜK}

\subsection{Thermomyces lanuginosus eredetü fitáz enzim előállítása}

\subsubsection{Törzsszelekció}

Különböző törzsgyüjteményekből származó 14 Thermomyces lanuginosus törzs szelektálását végeztem el fitáz aktivitásuk alapján. A törzsszelekciót 3\% kukoricaliszt tartalmú tápközegen valósítottam meg, mely fitát tartalmánál fogva alkalmas lehet fitáz enzim termelés indukálására (GREINER \& KONIETZNY 2006). Eredményeimet a 9. ábrán mutatom be.

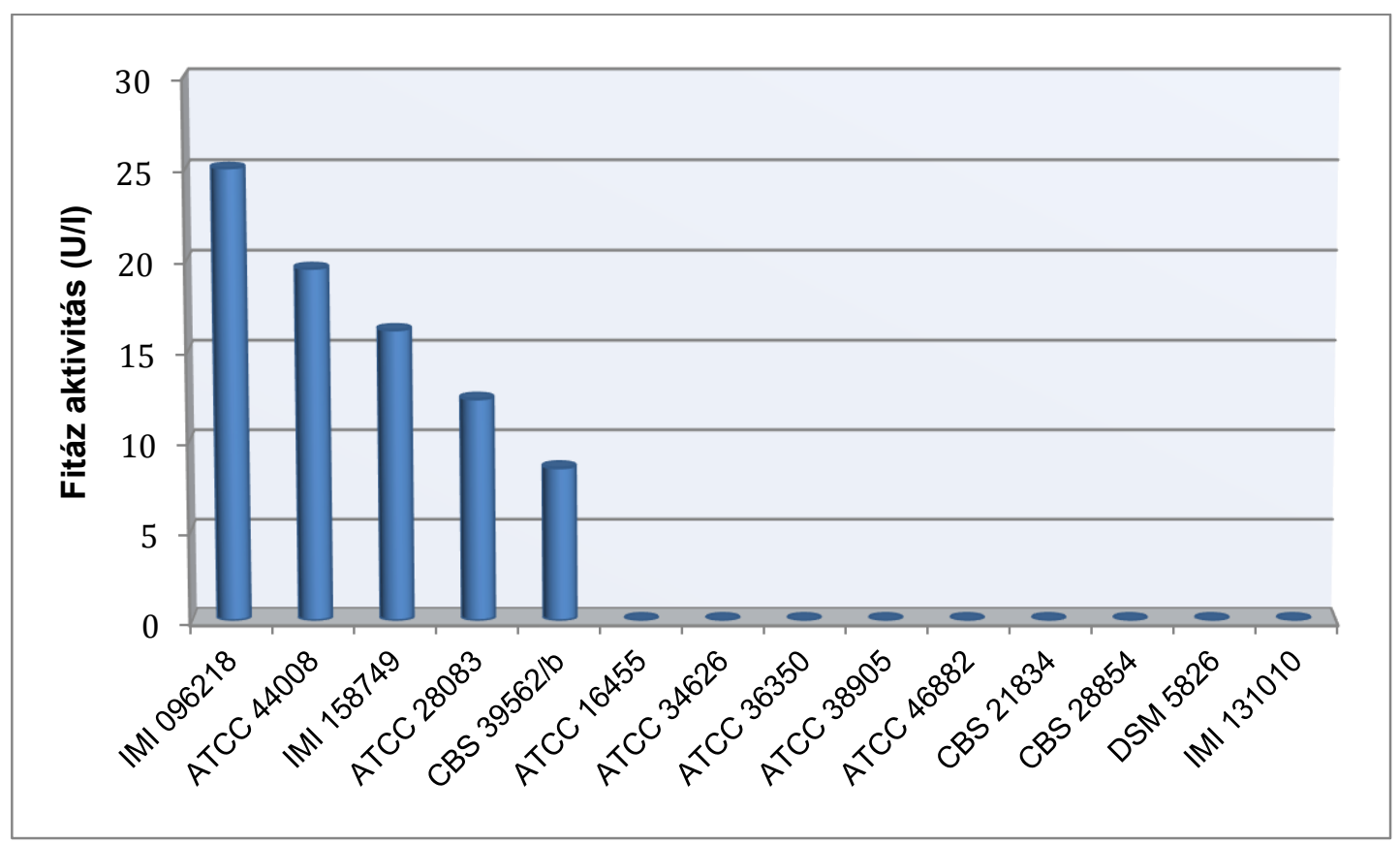

9. ábra Thermomyces lanuginosus törzsek rangsorolása fitáz aktivitásuk alapján $\left(47^{\circ} \mathrm{C}, 220 \mathrm{rpm}, 3 \%\right.$ koncentráció)

A 14 vizsgált törzsből 5 esetben tapasztaltam fitáz enzimaktivitást, az IMI 096218, ATCC 44008, IMI 158749, ATCC 28083, valamint a CBS 395.62/b törzsek esetén, míg a többi törzs az adott körülmények között nem szintetizált extracelluláris fitáz enzimet. Az aktivitást mutató törzseknél az aktivitás 8,5-25 U/1 értékek között változott, a legnagyobb mértékü aktivitást az IMI 096218 törzsnél mértem, a fermentáció 2. napján.

CHADHA és munkatársai (2004) komposztból izolált termofil gombák fitáztermelő képességét vizsgálták Ca-fitát tartalmú tápközegben, s a következő eredményeket kapták (U/ml): Sporotrichum thermophile 2,20 U/ml, Rhizomucor miehei-II 0,76 U/ml, Thermomyces lanuginosus-II 0,53 U/ml, Humicola insolens 0,22 U/ml, Rhizomucor miehei-I 0,2 U/ml, Thermomyces lanuginosus-I 0,2 $\mathrm{U} / \mathrm{ml}$, továbbá Aspergillus fumigatus $0,04 \mathrm{U} / \mathrm{ml}$. E törzsek fitáz termelő képességét több munkacsoport is bizonyította és tanulmányozta mind szubmerz, mind szilárd szubsztrátumú fermentációk során (SINGH \& SATYARAYANA 2008, GULATI et al. 2007b, BERKA et al. 
1998, JAVED et al. 2010).

Kutatásaim eredményeként szubmerz fermentáció alkalmazásával, a legígéretesebbnek talált T. lanuginosus IMI 096218 törzzsel elért 0,025 U/ml fitáz aktivitás fokozását tápközeg optimálási kísérletekkel tervezem megvalósítani.

A szakirodalomban különböző reakció idők találhatók a fitáz enzimaktivitás mérésének tanulmányozása során: A. niger eredetű enzim esetén HEINONEN és LAHTI (1981) módszerét módosítva, CASEY és WALSH (2003) 60 perces reakció időt alkalmaztak 55 C-on, míg MANDVIWALA és KHIRE (2000) 30 percig 50 C-on, GARGOVA és SARIYSKA (2003) pedig $58^{\circ} \mathrm{C}$-on, 10 percig inkubálta az enzimet Na-fitát szubsztrátum jelenlétében. Thermomyces lanuginosus esetén BERKA és munkatársai (1998) 20 perces reakcióidőt alkalmaztak, 50C-on. A fitáz aktivitás meghatározását ENGELEN és munkatársai (1994) leírása alapján végeztem, akik $37^{\circ} \mathrm{C}$-on, 1 órás reakció idő után mérték a Na-fitát szubsztrátumból felszabaduló foszfortartalmat. Mérések alapján 10 perces reakció idő elegendőnek bizonyult az enzimaktivitás meghatározására.

\subsubsection{Tápközeg összetétel optimálása}

\subsubsection{Tápközeg pH-jának hatása a fitáz termelésre}

Mivel a környezeti pH jelentősen befolyásolja a gomba metabolikus aktivitását, ezért fontosnak tartottam meghatározni azt a kiindulási pH értéket, melynél maximális aktivitás érhető el. A rázott lombikos fermentációk esetén a $\mathrm{pH}$ szabályozása a tápközegek pufferolásával valósítható meg, így a tápközeget $\mathrm{pH}=3,5$ és $\mathrm{pH}=5,5$ között Na-acetát pufferrel, a $\mathrm{pH}=5,5-9$ értékü tápközegeket TRIS-maleát/NaOH pufferrel készítettem el. A fermentációs tápközegek elkészítéséhez foszfátmentes puffert választottam, mivel a tápközeg foszfortartalma gátolhatja a fitáz aktivitást. Az enzimtermelés alakulását a fermentáció 4. napján a 10. ábrán mutatom be.

Az eredmények alapján megállapítható, hogy két optimum érték is van. A fitáz aktivitás kiemelkedő a $\mathrm{pH}=7,5$ értékű TRIS-maleát/ $\mathrm{NaOH}$ puffer alkalmazásával készített tápközeg esetén. $\mathrm{pH}=4,5$ és $\mathrm{pH}=6$ értékek között enzimaktivitás nem detektálható. Az enzimtermelés egyértelműen a semlegeshez közeli, illetve az enyhén lúgos pH értékü pufferrel készített tápközegek esetén a legkedvezőbb, $\mathrm{pH}=7,5$-nél lúgosabb közegben az aktivitás csökken. Ugyanakkor kismértékü aktivitás megfigyelhető a $\mathrm{pH}=4$ értékü tápközegben is, mely értéke $25 \%$-a a $\mathrm{pH}=7,5$ értéknél kapott aktivitásnak. 


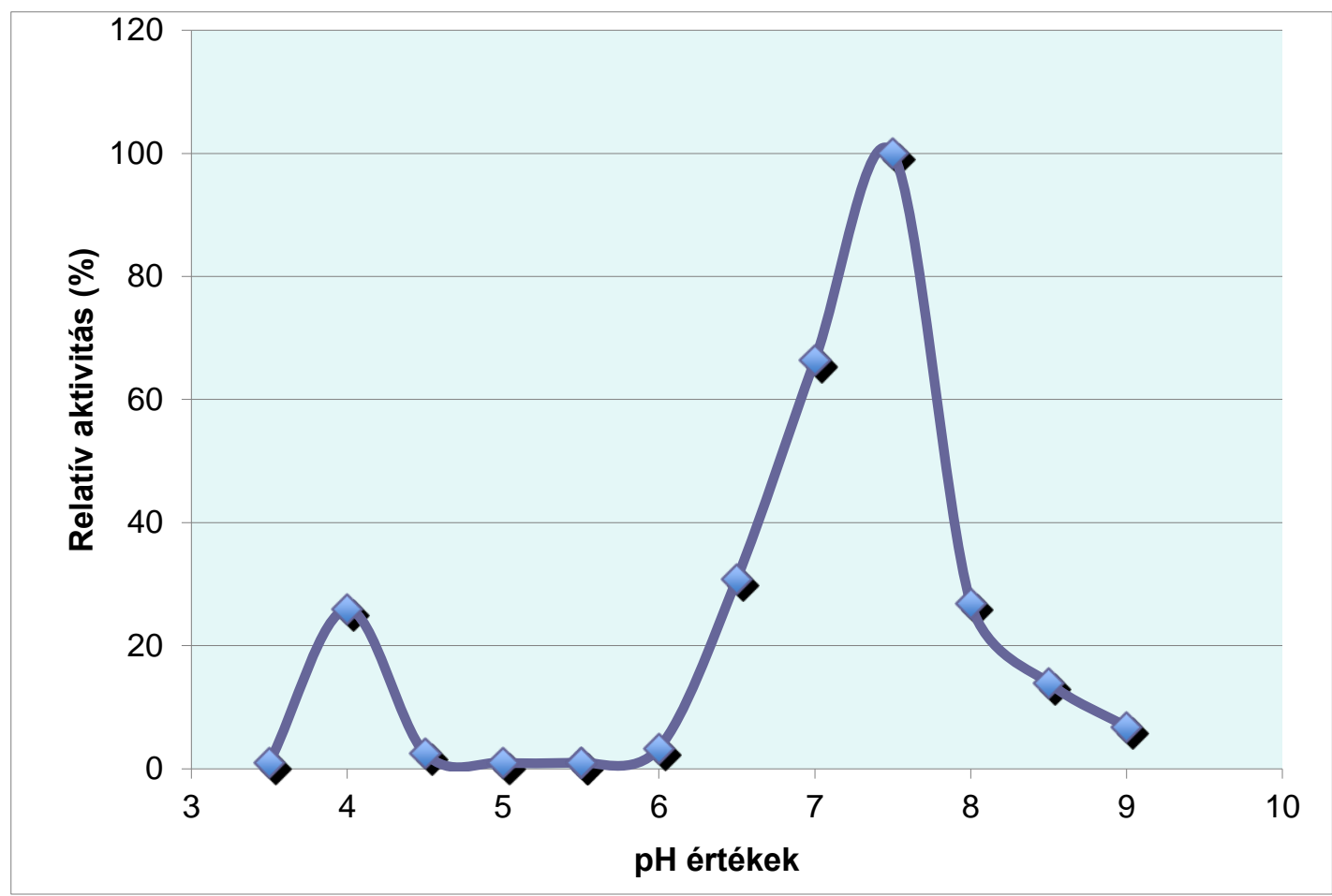

10. ábra A tápközeg kiindulási pH-jának hatása a Thermomyces lanuginosus IMI 096218 törzs fitáz enzim termelésére a fermentáció 4. napján $\left(47^{\circ} \mathrm{C}, 220 \mathrm{rpm}\right)$

GUPTA és MAHESHWARI (1985) állásfoglalása szerint is szükséges a pH szabályozás szintetikus tápközegben glükóz szénforrás mellett a Thermomyces lanuginosus megfelelő növekedéséhez. Az általuk javasolt érték $\mathrm{pH}=5,5$ és 7 közötti. Eredményeim is ezt mutatják, ugyanis a fermentáció során tapasztalt $\mathrm{pH}$ 6,3-7 értékek között változott. A pH szabályozás fontos a tápközegben lévő szén-dioxid koncentrációja miatt is, ugyanis az alacsony $\mathrm{pH}$ csökkenti a $\mathrm{CO}_{2}$ oldhatóságát a tápközegben, valamint az asszimilációjához szükséges enzim, a piruvát-karboxiláz aktivitását is.

Hasonló eredményeket tapasztaltak CHADHA és munkatársai (2004) termofil Rhizomucor pusillus búzakorpán megvalósított szilárd szubsztrátumú fermentációja során vizsgálva a tápközeg pH-jának hatását. Megállapították, hogy $\mathrm{pH}=8$ értékü TRIS puffer alkalmazásával érhető el a maximális fitáz termelés.

A kapott eredmények alapján, a további kísérleteim során a fermentációs tápközegeket pH=7,5 TRIS-maleát/NaOH pufferrel készítettem.

\subsubsection{Szénforrás hatása az enzimtermelésre}

A törzsszelekciót követően, a kiválasztott IMI 096218 törzzsel táptalaj optimálási kísérleteket valósítottam meg a pufferelt tápközegben. A rangsorolásnál alkalmazott rizsliszt mellett, különböző, a takarmányozásban is alkalmazható fitát tartalmú növényi eredetü alapanyagok felhasználásával végeztem fermentációkat fitáz enzim előállítására. 5 (w/v)\% koncentrációban 
alkalmaztam szójalisztet, búzakorpát, kukoricalisztet, valamint rizslisztet az egyes tápközegekben és a 3. naptól kezdve napi mintavételezéssel követtem a fitáz aktivitás alakulását. Eredményeimet a 11. ábrán mutatom be.

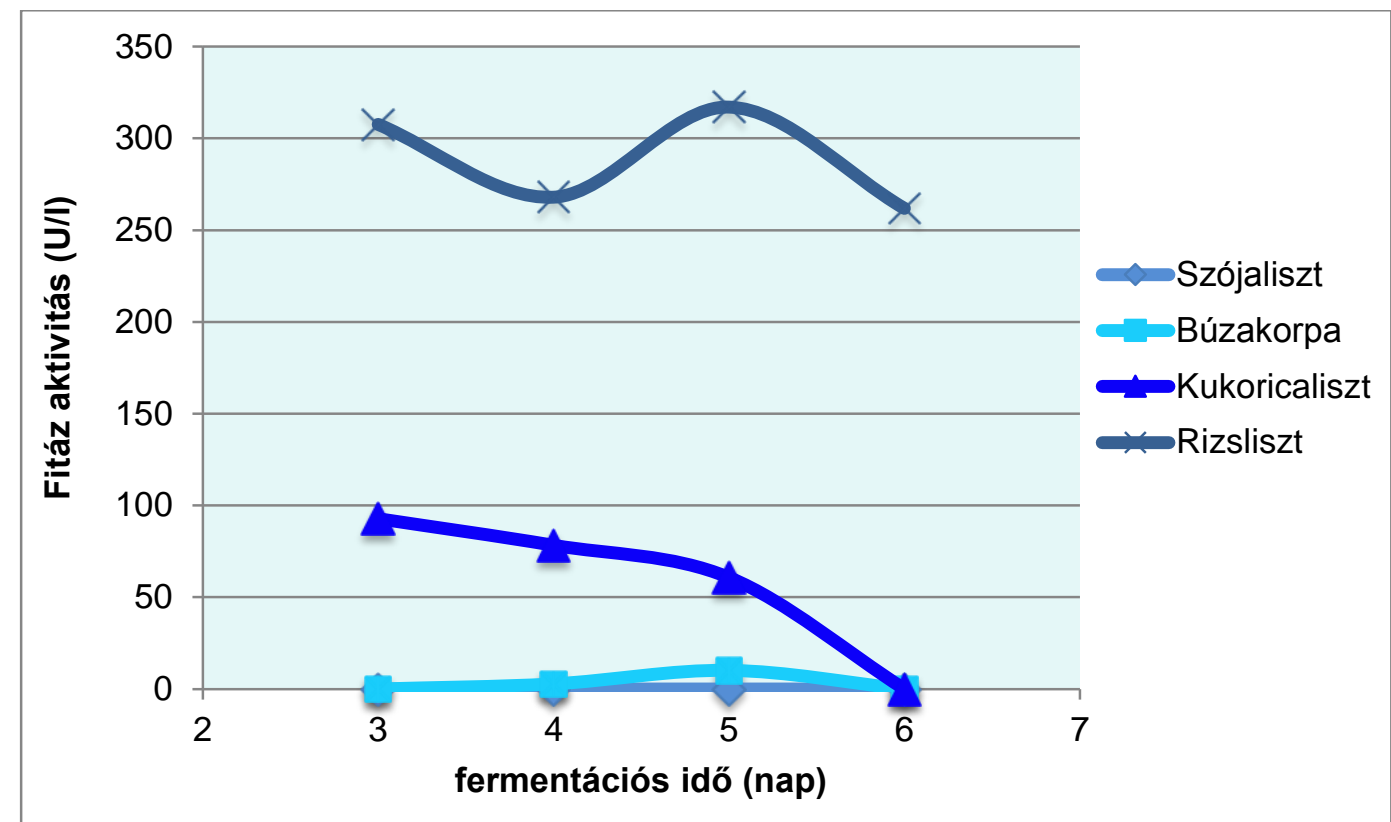

\section{1. ábra Különböző szubsztrátumok hatása a fitáz termelésre T. lanuginosus} IMI 096218 törzs esetén $\left(47^{\circ} \mathrm{C}, 220 \mathrm{rpm}, 5 \%\right.$ koncentráció)

A legnagyobb aktivitás értékeket a rizsliszt tartalmú tápközeg esetén kaptam a fermentáció során, míg szójaliszten nem tapasztaltam enzimaktivitást. Ennek oka lehet, hogy míg a többi tápközeg esetén a pH=6,3-6,4 körüli értékü, szójaliszt esetén a fermentáció 3. napján a fermentlé pH értéke 8,4 volt és ez fokozatosan növekedett $\mathrm{pH}=9$-ig. Búzakorpán az 5. napon volt mérhető aktivitás, míg a kukoricaliszt tartalmú tápközeg esetén a 3. nap mértem a legnagyobb aktivitást, melynél a rizsliszten elért fitáz hozam mintegy 3-szor nagyobb volt. Míg kukoricaliszten a 3., rizsliszten, valamint búzakorpán is az 5. napon maximális az enzimtermelés. Rizsliszt esetén azonban megfigyelhető, hogy a 3. és 5. napi aktivitás értékek között nincs jelentős különbség, azonban a 4. napon az aktivitás csökken. A 10. táblázatban összefoglaltam néhány növényi eredetű élelmiszer összetevőit, többek között fitinsav, szénhidrát és foszfortartalmát. Megnézve ezek összetételét a következő látható a vizsgált anyagok fitinsav tartalma esetén: a legnagyobb fitinsav tartalommal a búzakorpa rendelkezik $(3,38 \mathrm{~g} / 100 \mathrm{~g})$ és a szakirodalomban olvasottak alapján is elmondható, hogy a legjellemzőbb a búzakorpán megvalósított fitáz enzim fermentáció. Ennek ellenére, kutatásaim alapján a T. lanuginosus IMI 096218 törzzsel rizsliszt alapú tápközegben értem el a legnagyobb fitáz aktivitást, s jelentősebb enzim termelést még a szintén kisebb fitinsav tartalmú kukoricaliszten mértem, ezek fitinsav tartalma: kukoricaliszt $0,4 \mathrm{~g} / 100 \mathrm{~g}$, rizsliszt $0,1 \mathrm{~g} / 100 \mathrm{~g}$. Megfigyelhető tovább, hogy a rizsliszt foszfor tartalma a legalacsonyabb a többi nyersanyaghoz 
képest, ennek köszönhetően feltételezhető, hogy a gomba foszfor szükségletének kielégítésére nagyobb mértékü fitáz enzimet termel.

10. táblázat Növényi eredetü élelemiszerek fitinsav tartalma (RODLER 2005)

\begin{tabular}{|l|c|c|c|c|}
\hline $\begin{array}{l}\text { Növényi eredetü } \\
\text { élelmiszerek }\end{array}$ & Fitinsav & Szénhidrát & Foszfor & Élelmirost \\
\hline Borsóliszt & 1,1 & {$[\mathrm{~g} / 100 \mathrm{~g}]$} & {$[\mathrm{gg}]$} & {$[\mathrm{g} / 100 \mathrm{~g}]$} \\
\hline Szójaliszt & 1,2 & 33 & 438 & 23 \\
\hline Árpaliszt & 0,8 & 63 & 500 & 22 \\
\hline Rizsliszt & 0,1 & 79,4 & 165 & 10,8 \\
\hline Kukoricadara & 0,38 & 70,2 & 90 & 4,6 \\
\hline Kukoricaliszt & 0,4 & 66,3 & 170 & 5,5 \\
\hline Búzaliszt & 0,041 & 70,6 & 100 & 5,4 \\
\hline Búzadara & 0,96 & 73,4 & 120 & 3,2 \\
\hline Búzakorpa & 3,38 & 51 & 1143 & 4,07 \\
\hline
\end{tabular}

SINGH és SATYARAYANA (2008) Sporotrichum thermophile szubmerz fermentációja során búzakorpa kiegészítést alkalmaztak, s megnövekedett fitáz enzimtermelést tapasztaltak. Szintén búzakorpán állítottak elő fitázt Mucor indicus, valamint Rhizomucor pusillus gomba fermentációjával (GULATI et al. 2007c, CHADHA et al. 2004). Ez utóbbi gomba esetén különböző szénforrásokat hasonlítottak össze, mint búzakorpa $(2,21 \mathrm{U} / \mathrm{ml})$, rizs csuhé $(2,15 \mathrm{U} / \mathrm{ml})$, rizskorpa $(0,32 \mathrm{U} / \mathrm{ml})$, halliszt $(0,25 \mathrm{U} / \mathrm{ml})$, kukoricaszem $(0,03 \mathrm{U} / \mathrm{ml})$ és kukorica glutén $(0,01 \mathrm{U} / \mathrm{ml})$. Bár a búzakorpa adta a legnagyobb aktivitás értéket, de közel azonos eredményt értek el rizs csuhé szubsztrátumként való alkalmazásával.

Összeségében a rizsliszten megvalósított fermentáció során mért fitáz aktivitás a búzakorpán mértnek 30-szorosa, ennek megfelelően további optimálási kísérleteimet rizsliszt alapú tápközegben végeztem.

\subsubsection{A hömérséklet hatása a fitáz enzim aktivitására}

Az enzimaktivitás szempontjából optimális hőmérséklet megállapítását céloztam meg a következő kísérletben. A termofil gombák által termelt enzimek hőmérséklet optimuma várhatóan magasabb, mint $37^{\circ} \mathrm{C}$, ezért célom volt meghatározni azt a hőmérsékletet, melynél az enzim reakció sebessége a legnagyobb. A kísérlethez az IMI 096218 törzzsel végzett 2 napos fermentáció során kapott szürletet használtam fel. Az inkubációt 10 percen keresztül $35-85^{\circ} \mathrm{C}$ közötti hőmérséklet 
tartományban, a hőmérséklet $5^{\circ} \mathrm{C}$-onkénti emelésével végeztem. Mérési eredményeimet a 12 . ábrán mutatom be.

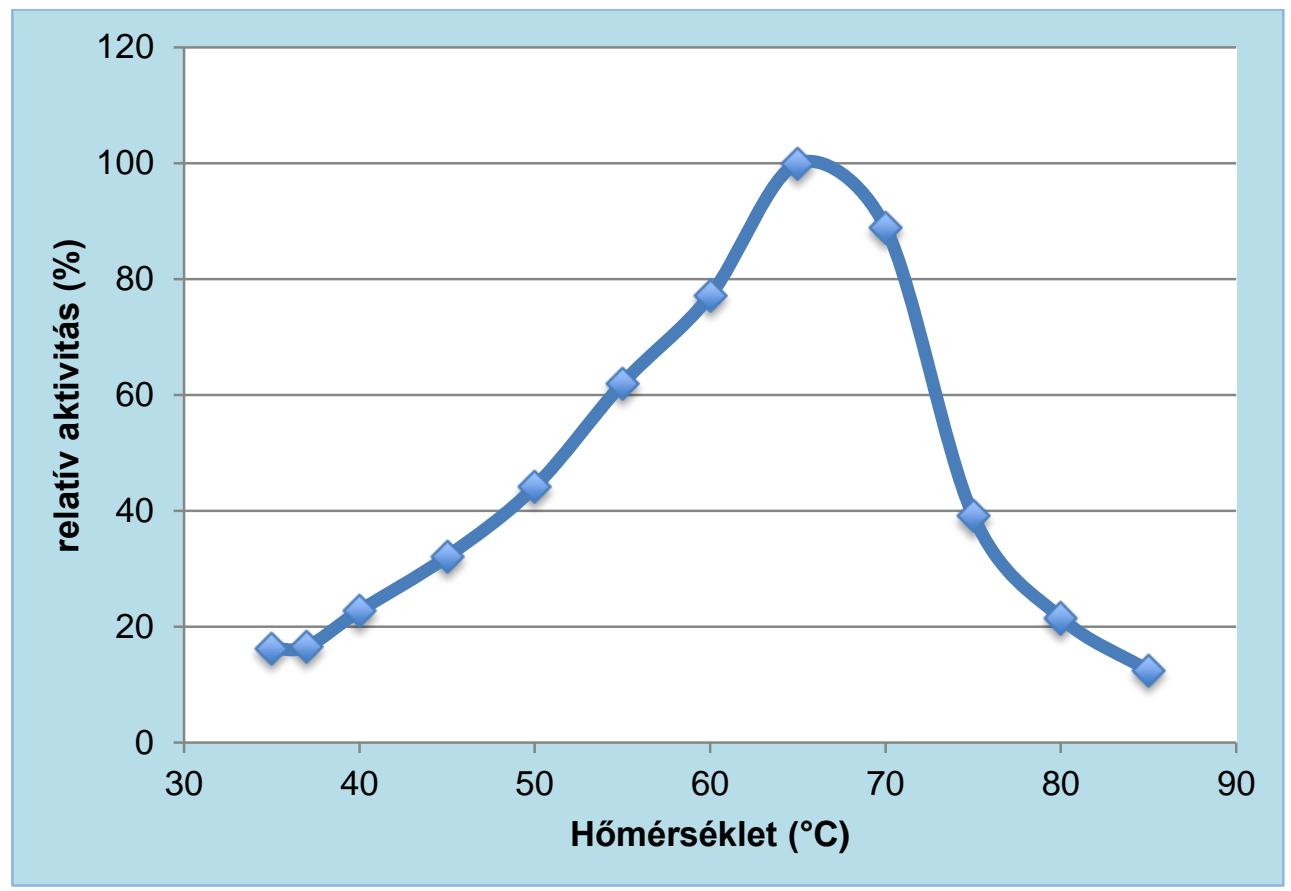

12. ábra A hőmérséklet hatása a fitáz enzim aktivitására

(Thermomyces lanuginosus IMI 096218, 2 napos fermentáció)

A maximális fitáz aktivitást $65^{\circ} \mathrm{C}$-on mértem. Bár a hőmérséklet további emelésével az aktivitás meredeken csökkent, a $80^{\circ} \mathrm{C}$-on mért aktivitás közel azonos a $40^{\circ} \mathrm{C}$-on kapott értékkel. A maximális aktivitás meghatározása következtében a továbbiakban az aktivitás mérést $65^{\circ} \mathrm{C}$-on végeztem.

\subsubsection{A rizsliszt koncentrációjának hatása a fitáz aktivitásra}

Az enzimaktivitást befolyásoló tényezők közé tartozik a fermentációban jelen lévő szubsztrátum koncentráció is, ezért kísérleteim során azt a koncentrációt kívántam meghatározni, melynél maximális enzimtermelés érhető el. A rizslisztet $2(\mathrm{w} / \mathrm{v}) \%, 4(\mathrm{w} / \mathrm{v}) \%, 5(\mathrm{w} / \mathrm{v}) \%, 6(\mathrm{w} / \mathrm{v}) \%$, $8(\mathrm{w} / \mathrm{v}) \%$ koncentrációban alkalmaztam a pufferelt tápközegekben. Az enzimtermelés alakulását már az első naptól követtem, s a maximális aktivitások átlag értékeit, melyeket a fermentáció 4. napján mértem a 13. ábrán mutatom be. 


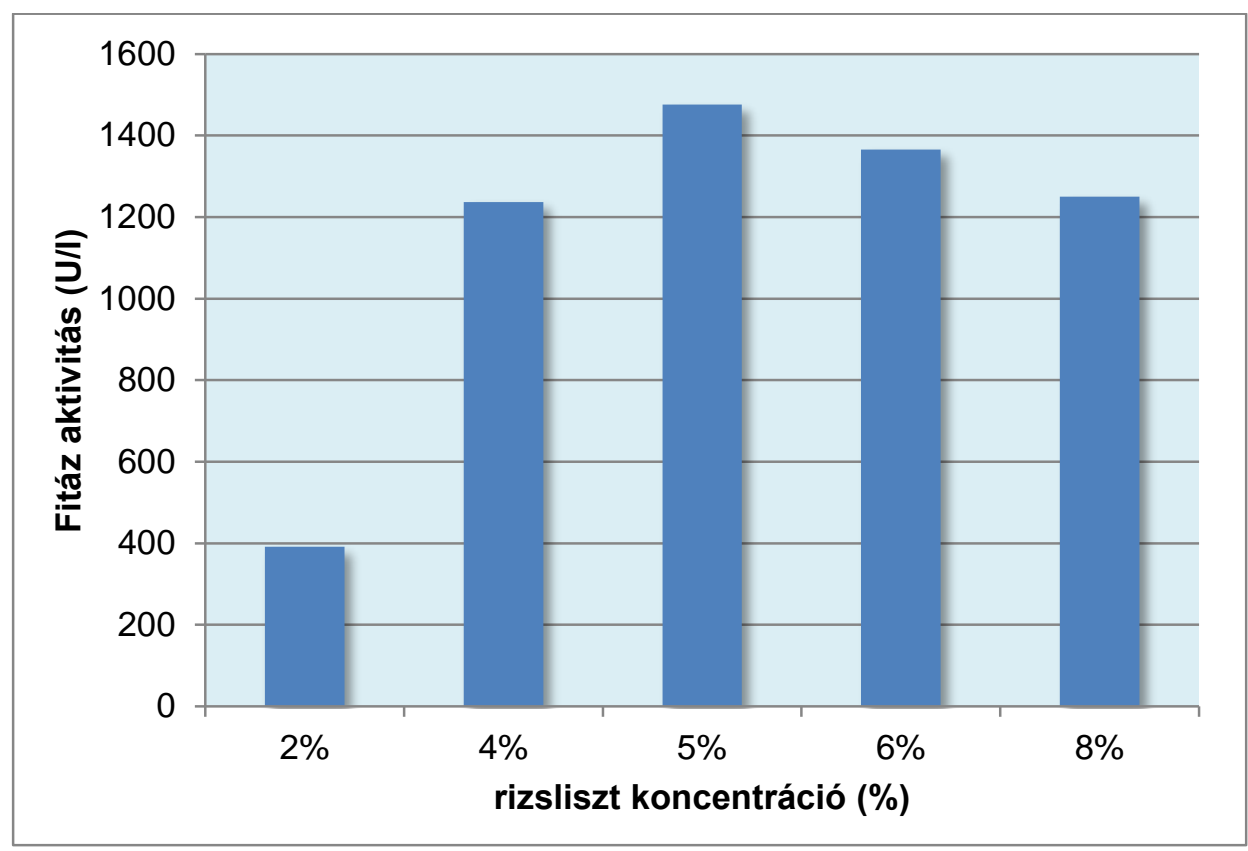

\section{3. ábra. A rizsliszt különböző koncentrációinak hatása a fitáz aktivitásra a fermentáció \\ 4. napján (Thermomyces lanuginosus IMI $096218,47^{\circ} \mathrm{C}, 220 \mathrm{rpm}$ )}

A koncentráció növelése $5(\mathrm{w} / \mathrm{v}) \%$-ig fokozza az enzim szintézist, $6(\mathrm{w} / \mathrm{v}) \%$ és $8(\mathrm{w} / \mathrm{v}) \%$ rizsliszt alkalmazásával magasabb értékeket már nem kaptam a fermentáció 4 napja során. A fenti eredmények alapján az 5\% rizsliszt koncentráció alkalmazása a legkedvezőbb a fitáz termeléshez. Megállapítható továbbá, hogy a fitáz enzim termeléshez rövidebb fermentációs idő - 4 nap - is elegendő, melynek eredményeként 1400 U/1 enzimaktivitást mértem.

\subsubsection{Rázatási sebesség hatása a fitáz aktivitásra}

A különböző rizsliszt koncentrációk alkalmazása mellett a rázatási sebesség hatását is vizsgáltam. A rázatási sebesség befolyásolja a tápanyagok, valamint az oxigén elérhetőségét, ezáltal a levegőztetés hatékonyságát is.

A Thermomyces lanuginosus megfelelő szaporodásához szükséges oxigén ellátást $220 \mathrm{rpm}$ fordulatszámmal müködö rázóinkubátorral biztosítottam. A jelen kísérlet során összehasonlítottam a fitáz termelés alakulását $220 \mathrm{rpm}$, valamint csökkentett, $120 \mathrm{rpm}$ rázósebesség alkalmazása mellett. A párhuzamos kísérletek átlag értékei a 14. ábrán láthatók.

A különböző rázatási sebességgel végzett fermentációk során megállapítottam, hogy 220 rpm alkalmazásával a gomba enzimtermelése időben gyorsabb, a 4. napon éri el a maximumát, míg 120 rpm esetén a fermentáció 7. napján volt maximális az enzimtermelés. 


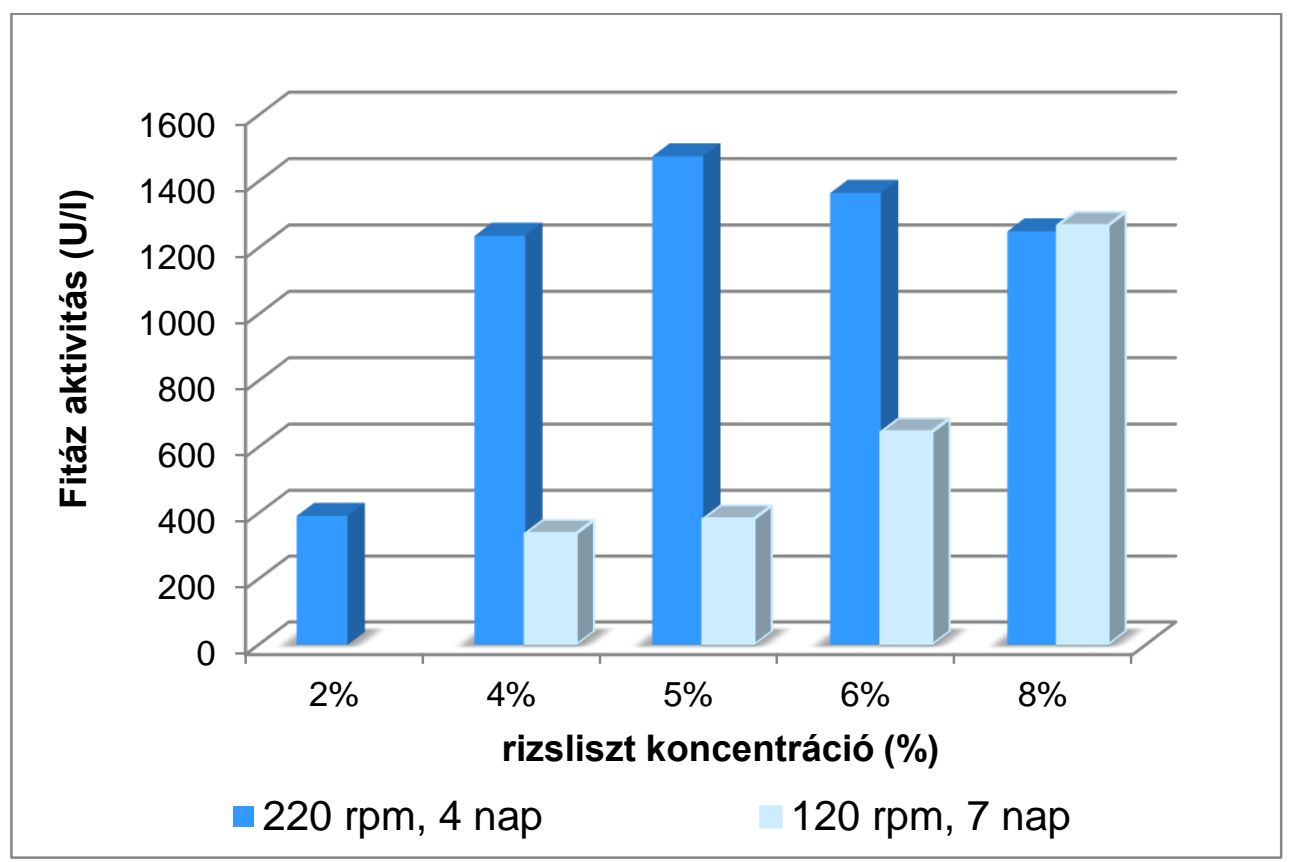

\section{4. ábra A maximális fitáz aktivitás összehasonlítása 120 rpm és $220 \mathrm{rpm}$ rázósebességen vezetett fermentációknál (Thermomyces lanuginosus IMI 096218, 47 C)}

A nagyobb fordulatszámon, a fermentáció során nagyobb aktivitás értékeket mértem, a legjobbnak az 5 (w/v)\% rizsliszt bizonyult, melynél közel négyszeres a kapott enzimtiter. Kisebb fordulatszámon a koncentráció növelésével az aktivitás is növekszik. 8 (w/v)\% rizsliszt alkalmazásával azonos aktivitás értékek érhetők el, csupán a fermentációs idő eltérő: míg 220 1/perc fordulaton már a 4. nap, 120 1/percen a 7. nap mértem 1250 U/1 aktivitást. 8 (w/v)\%-os rizsliszt koncentráció alkalmazása szubmerz körülmények között erősen viszkózus tápközeget eredményez, mely megnehezíti a kevertetést és a levegőztetést. A termofil gombák azonban kedvelik azon környezetet, ahol magas a hőmérséklet és a páratartalom, pl. komposzt, továbbá a szén-dioxid jelenléte is állandó, 10-15\% (MAHESHWARI et al. 2000). Bár a szén-dioxid nem tekinthető növekedési faktornak, a Thermomyces lanuginosus növekedését negatívan befolyásolja, ha környezete szén-dioxid mentes. A rázatási sebesség hatását vizsgálták SINGH és SATYANARAYANA (2012) Sporotrichum thermophile termofil gomba fitáz termelésére, 0 és 300 rpm közötti fordulatszám alkalmazásával. Az álló helyzethez képest a fordulatszám növelésével fokozatosan növekedett az enzim aktivitása, az oxigén és tápanyagok kedvezőbb elérhetősége révén. A legnagyobb aktivitás értéket $250 \mathrm{rpm}$ esetén érték el, azonban a sebesség további növelése a gomba micéliumok töredezéséhez, a tápanyagok felvételének akadályozásához és az enzimtermelés csökkenéséhez vezetett. Hasonló tapasztalataim alapján a továbbiakban is a Thermomyces lanuginosus növekedésének és enzimtermelésének kedvezöbb, 220 rpm fordulatszámon vezettem a fermentációkat. 


\subsubsection{Különbözö tápkomponensek hatása az aktivitásra}

Mivel a fermentációs tápközeg csupán szervetlen nitrogént tartalmaz, vizsgáltam a szerves nitrogén és vitaminforrásként szolgáló élesztőkivonat kiegészítés hatását az enzim aktivitására nézve. Vizsgálataimba bevontam a Tween 80 felületaktív anyagot, melynek alkalmazása pozitív hatású lehet az extracelluláris enzimek kiválasztására, ugyanis jelenlétében a sejtmembán áteresztőképessége növekszik, szabad utat adva az enzimnek a sejtből való kijutásra. A citromsav kiegészítés hatását is vizsgálni kívántam a fitáz termelésre vonatkozóan, ezért a 11. táblázatban látható kísérleti beállításnak megfelelően egészítettem ki a rizslisztes tápközeget a vizsgálni kívánt anyagokkal önmagunkban és különböző kombinációkban 0,1 (w/v)\% koncentrációban. A 11. táblázatban tüntettem fel továbbá a hatás mértékét is, melynél a 25\%-nál nagyobb mértékü változást fogadtam el számottevőnek. Kontrollként a rizslisztes alaptápközeget használtam, mely semmilyen hozzáadott anyagot nem tartalmazott.

11. táblázat Tápközeg kiegészítők összetételei az egyes kísérleti beállításoknál

\begin{tabular}{|c|c|c|c|c|}
\hline \multirow{2}{*}{$\begin{array}{c}\text { Kísérleti } \\
\text { beállítás }\end{array}$} & Élesztökivonat & Tween 80 & Citromsav & Hatás \\
\hline 1 & $0,1 \%$ & - & - & \\
\hline 2 & - & $0,1 \%$ & - & + \\
\hline 3 & - & - & $0,1 \%$ & - \\
\hline 4 & $0,1 \%$ & $0,1 \%$ & - & + \\
\hline 5 & $0,1 \%$ & - & $0,1 \%$ & - \\
\hline 6 & - & $0,1 \%$ & $0,1 \%$ & - \\
\hline 7 & $0,1 \%$ & $0,1 \%$ & $0,1 \%$ & \\
\hline \hline 8 (kontroll) & - & - & - & \\
\hline
\end{tabular}

Az élesztőkivonat egyedüli adagolásával kismértékű aktivitás növekedés mérhető. Élesztókivonat és Tween 80 együttes alkalmazása esetén tovább nőtt az aktivitás, hasonlóan DHARMSTHITI és munkatársai (2004) eredményeihez, akik a Pseudomonas putida fitáz termelésének fokozására élesztókivonat, citromsav és Tween 80 együttesét alkalmazták. Thermomyces lanuginosus esetén a citromsav azonban egyértelműen gátolja a fitáz enzim termelését, az aktivitás közel $90 \%$-kal kisebb, mint a kontroll mintáé. A Tween 80 felületaktív anyag alkalmazása eredményezte a legnagyobb mértékü aktivitás növekedést. ARNESEN és munkatársai (1998) Thermomyces lanuginosus $\alpha$-amiláz enzim termelését és kiválasztását fokozták sikeresen Tween 80 alkalmazásával, s mintegy 2,7-szeres aktivitás növekedést tapasztaltak. 


\subsubsection{Felületaktív anyagok hatása}

A különböző anyagok kombinációi nem adtak kedvezöbb eredményeket, mint a Tween 80 egyedüli alkalmazása, így a továbbiakban ezen anyagot, valamint a polioxietilén szorbitán egyéb észtereit vizsgáltam az enzimtermelés fokozása érdekében.

A polioxietilén szorbitán észterei a felületaktív anyagok körébe tartoznak, melyek közül a polioxietilén szorbitán monooleát, azaz a Tween-80 enzim termelést növelő hatását már leírták (VATS \& BANERJEE 2004, LI et al. 2001, ARNESEN et al. 1998).

Tween 20, Tween 40, Tween 60, Tween 65, Tween 80 és Tween 85 felületaktív anyagokkal $0,1(\mathrm{w} / \mathrm{v}) \%$ koncentrációban kiegészítve a tápközeget, naponkénti mintavételezéssel meghatároztam a fitáz aktivitás alakulását. A 15. ábrán a fermentáció 2. és 3. napján kapott relatív aktivitásokat tüntettem fel. Kimagasló eredményt a Tween 20 és Tween 40 alkalmazásával értem el, az aktivitás mintegy megkétszereződött. A Tween 60, Tween 65 és Tween 85 nem befolyásolta jelentősen a fitáz szintézist.

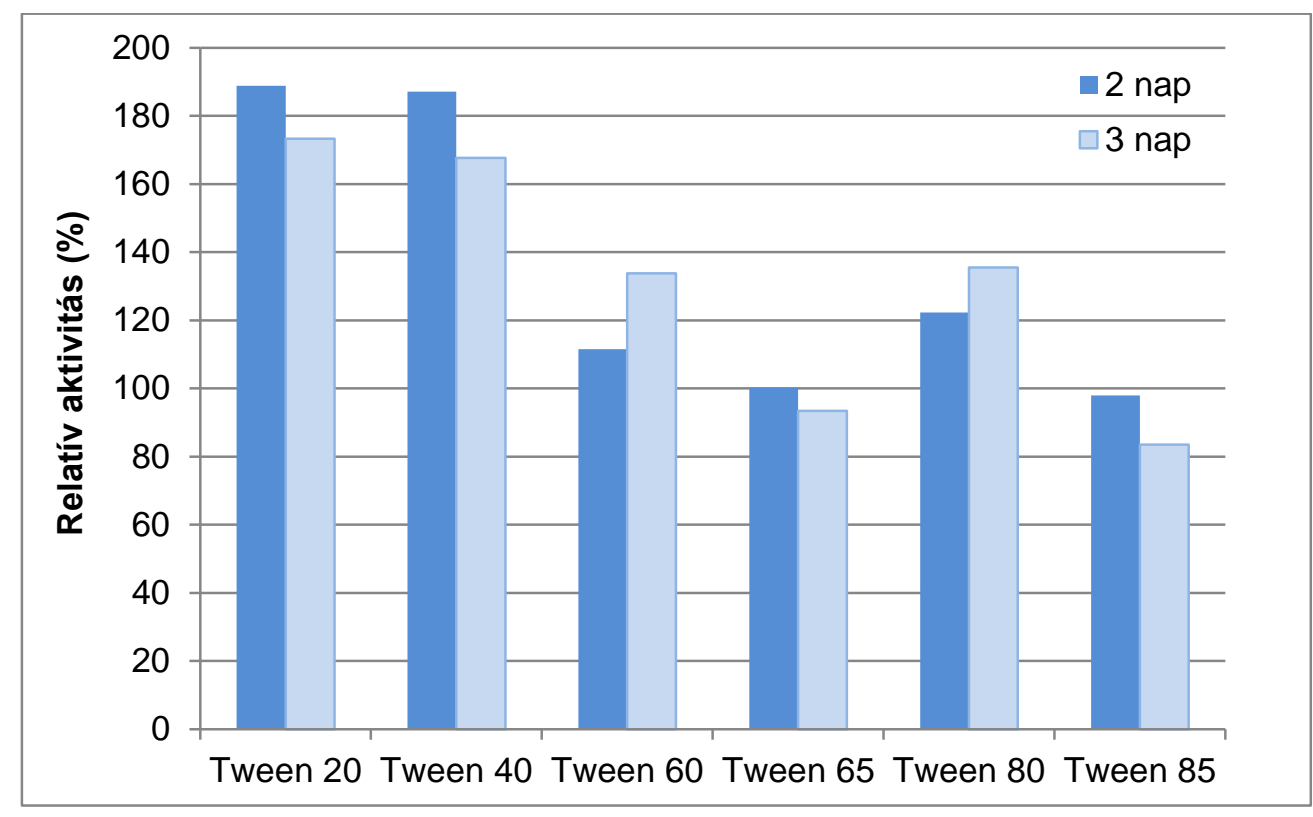

15. ábra Különböző Tween felületaktív anyagok hatása a fitáz aktivitásra

(Thermomyces lanuginosus IMI 096218, 47 C, $220 \mathrm{rpm}$ )

SINGH és SATYANARAYANA (2008) Sporotrichum thermophile fitáz termelése során azt tapasztalták, hogy $0,4 \%$ Tween 80 és $0,5 \%$ Tween 20 alkalmazásával érhető el a legnagyobb aktivitás.

Mivel a felületaktív anyagok koncentrációja is jelentősen befolyásolhatja az enzimaktivitás alakulását, a továbbiakban különböző koncentrációban történő alkalmazásuk hatását vizsgáltam a fitáz termelésre, különös tekintettel a legjobb enzimhozam növelő Tween 20 és Tween 40 anyagok esetén. A koncentrációkat $0,1(\mathrm{w} / \mathrm{v}) \%$ és $1,5(\mathrm{w} / \mathrm{v}) \%$ között változtattam. Az eredményeim a fermentáció 2. napján a következőket mutatják (16. ábra): 


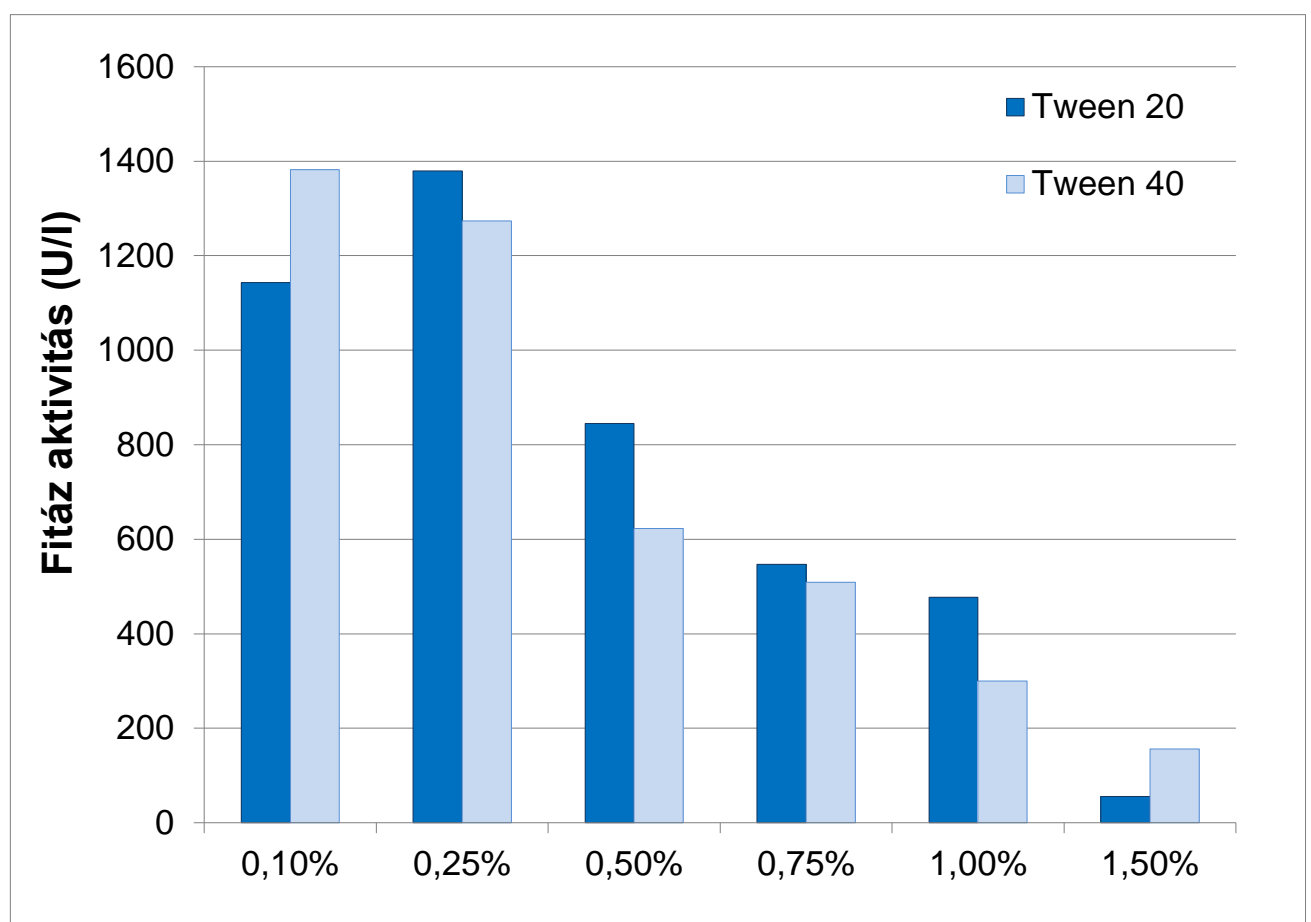

16. ábra Fitáz aktivitás alakulása különböző koncentrációjú Tween 20 és Tween 40 alkalmazása mellett a fermentáció 2. napján (T. lanuginosus IMI $096218,47^{\circ} \mathrm{C}, 220 \mathrm{rpm}$ )

Tween 40 0,1 (w/v)\%, illetve Tween 20 0,25 (w/v)\% koncentrációban történő alkalmazásával érhető el a maximális eredmény, mely a két felületaktív anyag esetén megegyező. A koncentráció $0,25(\mathrm{w} / \mathrm{v}) \%$ fölé emelése mindkét Tween esetében csökkent mértékü aktivitást mutat a fermentáció 2. napján, azonban a fermentáció előrehaladtával növekedés figyelhető meg (17. ábra). Tween 40 esetén a fermentáció 2. és 5. napja között az aktivitás alakulása azt mutatja, hogy minél nagyobb koncentrációban alkalmazzuk a felületaktív anyagot, annál nagyobb az aktivitás növekedésének mértéke. 0,5 és $0,75(\mathrm{w} / \mathrm{v}) \%$ koncentráció esetén 2-szeres, $1(\mathrm{w} / \mathrm{v}) \%$ esetén 3 -szoros, míg 1,5\% alkalmazásával 5-szörös aktivitás növekedés látható az 5. napon. Tween 20 esetén ez az összefüggés nem jelenthető ki, de itt is megfigyelhető, hogy 1,5 (w/v)\% koncentráció alkalmazása során az aktivitás a 2 és 5. nap között 13-szorosára nő. Mindezek ellenére leggazdaságosabban 0,1 (w/v)\% Tween 40 felületaktív anyag alkalmazásával, már 2 nap alatt elérhető a maximális enzimkihozatal. 

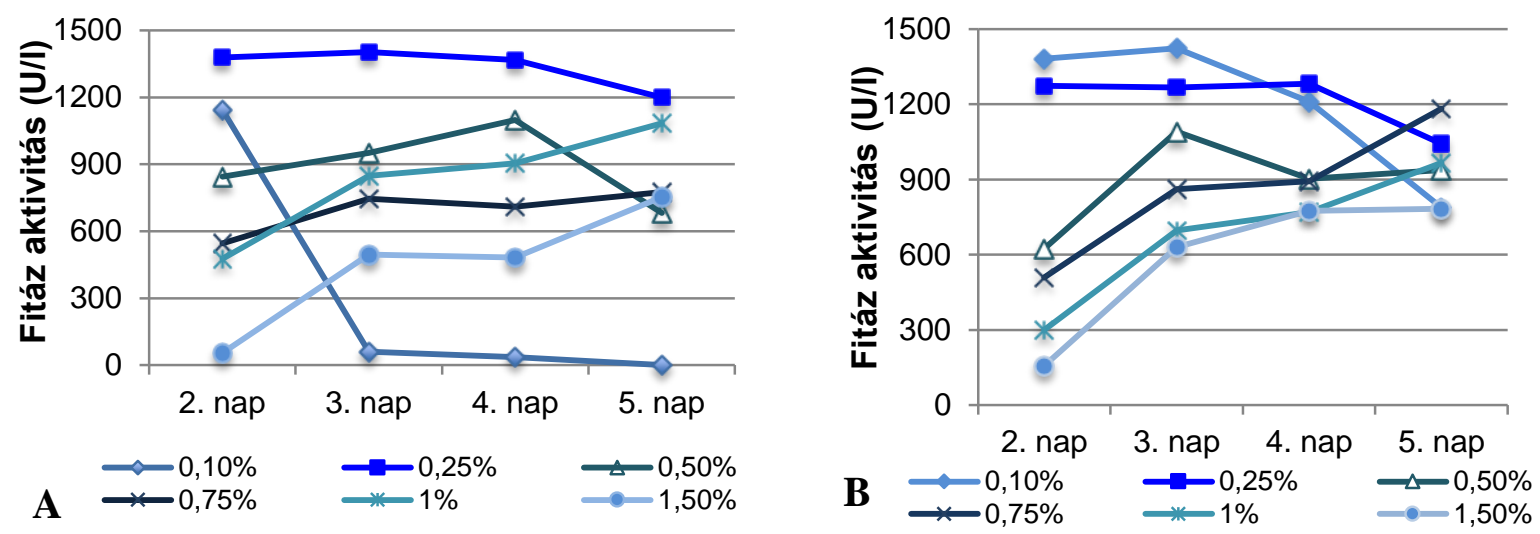

17. ábra Fitáz termelés alakulása különböző koncentrációjú Tween $20(\mathrm{~A})$ és Tween 40 (B) felületaktív anyagokkal kiegészített tápközegekben (T. lanuginosus IMI 096218, 47 $\mathrm{C}, 220 \mathrm{rpm}$ )

\subsubsection{Az inokulum tenyészet korának hatása az enzimtermelésre}

A fitáz fermentációs technológia kidolgozása érdekében standardizálni kívántam az inokulum készítést. Ennek érdekében első lépésként $1 * 10^{5}$ konídium $/ \mathrm{ml}$ koncentrációt rögzítettem az inokulum tenyészet indítására. A meghatározott korú inokulumokkal indított fermentációk eredményeit a 18. ábrán szemléltetem. Megállapítható, hogy különböző korú inokulumok alkalmazása jelentős hatást gyakorol a fitáz aktivitás alakulására. A legnagyobb, 2000 U/1 enzimaktivitást a 20 órás inokulummal indított fermentáció 2. napján, valamint a 40 órás inokulummal történő indítás esetén, a fermentáció 1. napján kaptam.

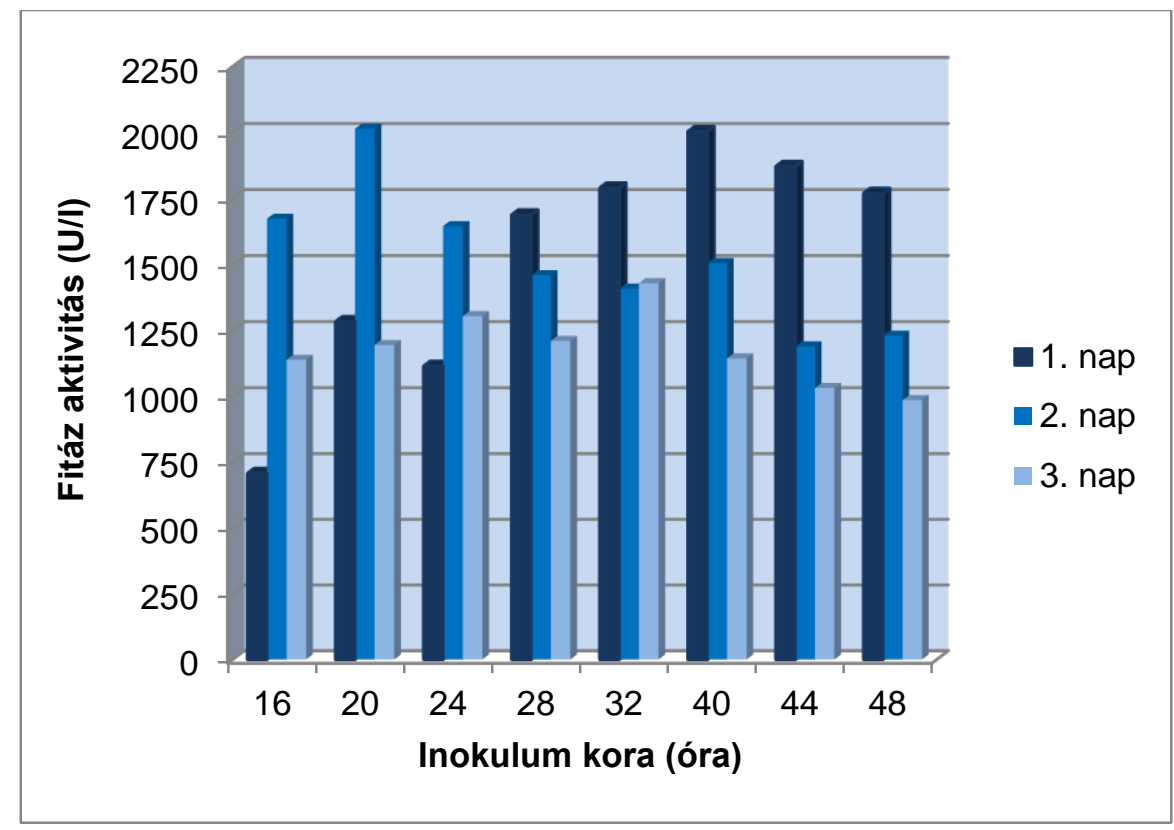

18 ábra. Különböző korú inokulummal indított fermentációk hatása a fitáz termelésre (Thermomyces lanuginosus IMI 096218, 47 C, $220 \mathrm{rpm}$ )

A fitáz fermentáció optimálása során vizsgálni kívántam az inokulum mennyiségének hatását is az enzimtermelésre. A 20 órás és 40 órás inokulumok mennyiségi optimálásával törekedtem az 
enzimtermelés további fokozására. $5(\mathrm{w} / \mathrm{v}) \%, 10(\mathrm{w} / \mathrm{v}) \%$ és $15(\mathrm{w} / \mathrm{v}) \%$ inokulum mennyiségek alkalmazásával indítottam a fermentációkat. E kísérlet során nagyobb különbségek tapasztalhatók a 20 és 40 órás inokulumokkal indított fermentációk fitáz aktivitásai között. 5 és 10 (w/v)\% inokulum mennyiség alkalmazásával a 40 órás inokulummal magasabb értékeket kaptam, kivételt képez a 15 $(\mathrm{w} / \mathrm{v}) \%$ inokulummal indított fermentáció, ahol a 20 órás inokulummal háromszoros aktivitást mértem, azonban ez az érték messze elmarad a legjobbnak talált beállítástól: a 40 órás inokulummal $5(\mathrm{w} / \mathrm{v}) \%$ mennyiséggel történő beoltás. A fermentáció során a maximális aktivitás értékeket a 2. napon mértem az 5 (w/v)\% inokulum mennyiséggel indított kísérleteknél, míg 10-15 (w/v)\% alkalmazása lassabb fermentációs időt eredményezett, a maximális értékek a 3-4 napon mérhetők.

Összegezve az eredményeket megállapítható, hogy a Thermomyces lanuginosus IMI 096218 törzs fitáz termeléséhez az optimálási kísérletek alapján a következő tápközeg összetétel ajánlható: rizsliszt $50 \mathrm{~g} / \mathrm{l}, \mathrm{MgSO}_{4} * 7 \mathrm{H}_{2} \mathrm{O}$ 0,5 g/l, $\mathrm{KCl}$ 0,5 g/l, $\mathrm{FeSO}_{4}$ 0,1 g/l, NaNO 3 8,6 g/l, Tween-40 1 g/l, Tris-maleát $/ \mathrm{NaOH}$ pufferben $(\mathrm{pH}=7,5)$ oldva. A maximális enzimtermelés már 2 napos fermentációval is elérhető az adott körülmények között.

Az optimált fermentációs technológia eredményeként a szkrínelésnél mért 25 U/1 aktivitásról, 1400-2000 U/1 értékre nőtt az enzimhozam, mely többmint 50-szeres növekedést jelent. Az aktivitás növelése mellett a fermentáció ideje is lecsökkent, amely egy gazdaságosabb technológiát eredményez, különösen termofil mikroorganizmus alkalmazása esetén, ahol ezáltal a magasabb inkubálási hőmérsékletet rövidebb ideig szükséges biztosítani.

\subsection{A termofil Thermomyces lanuginosus eredetü fitáz enzim tisztítása}

Az enzim jellemzéshez homogenitásig tisztított fehérjére volt szükségem. A Thermomyces lanuginosus IMI 096218 törzzsel optimált körülmények között megvalósított fermentáció tenyészlevéből a fitáz enzim tisztítását a kicsapást követő kromatográfiás eljárások kombinációjával valósítottam meg. A tisztítás folyamata a 19. ábrán látható. 


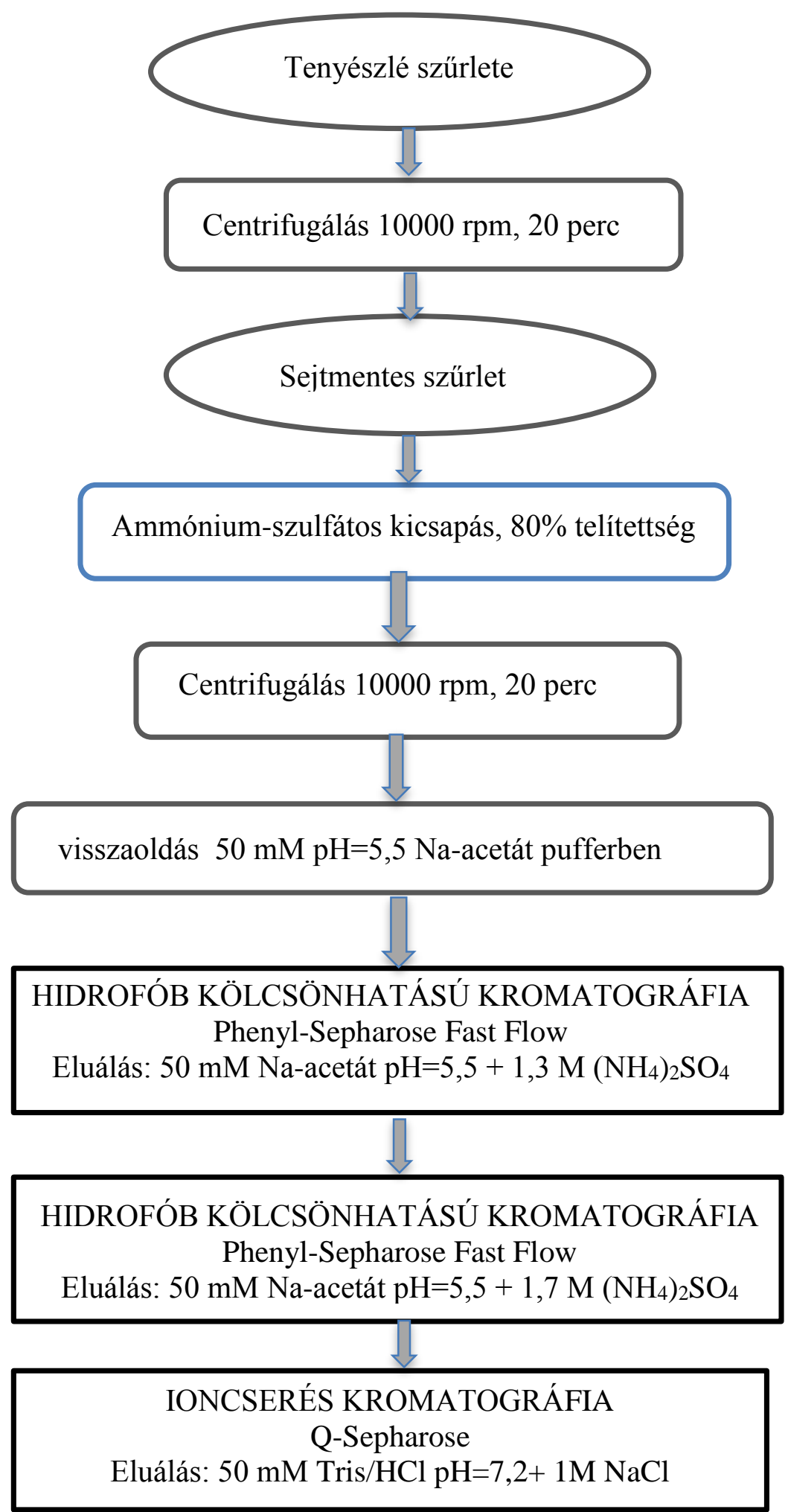

19. ábra A T.lanuginosus IMI 096218 törzs fitáz enzimének tisztítási lépései

Az enzim kinyerését ammónium-szulfátos kicsapással kezdtem, 80 \%-os telítettséget beállítva, s $4^{\circ} \mathrm{C}$-on történő állást követően az oldatot lecentrifugáltam (10000 rpm, 20 perc). A felülúszót leöntöttem és a kicsapódott fehérjetartalmú anyagot kis mennyiségü pH=5,5 $50 \mathrm{mM}$ Naacetát pufferben feloldottam. A fitáz enzim elválasztása a kísérőfehérjéktől az FPLC rendszerhez csatlakoztatott kromatográfiás oszlopokon történt. Minden egyes tisztítási lépés után a frakciókból meghatároztam a fitáz aktivitást mikrotiter lemez alkalmazásával, s a fehérje tartalmat $280 \mathrm{~nm}$-en. 
A tisztítás első lépéseként hidrofób kölcsönhatáson alapuló kromatográfiás technikát választottam, Phenyl Sepharose gyanta alkalmazásával. Az oszlopot (elöször $50 \mathrm{mM}$ Na-acetát pufferrel $\left(\mathrm{pH}=5,5\right.$ 1,3 $\left.\left.\mathrm{M}\left(\mathrm{NH}_{4}\right)_{2} \mathrm{SO}_{4}\right)\right)$ telítettem, majd injektáltam a mintát. A megkötött fehérjéket $50 \mathrm{mM}$ Na-acetát puffer segítségével eluáltam $3 \mathrm{ml} /$ perc áramlási sebességgel. A tisztítás után mértem a fitáz aktivitást, a fehérjetartalmat, s az aktív csúcshoz tartozó frakciókat összegyüjtöttem, koncentráltam. Ezt a lépést megismételtem az előzőekkel megegyező beállításokkal, $50 \mathrm{mM} \mathrm{Na-}$ acetát $\left.\left(\mathrm{pH}=5,5,1,7 \mathrm{M}\left(\mathrm{NH}_{4}\right)_{2} \mathrm{SO}_{4}\right)\right)$ puffer felhasználásával. A tisztítási kromatogramot a 20. ábrán mutatom be. A megkötött fehérjéket $50 \mathrm{mM}$ Na-acetát pufferrel eluáltam. A fitáz aktivitást mutató frakciókat egyesítettem, majd ultraszüréssel sótalanítottam és koncentráltam. Következőekben ezt a lépést megismételtem megnövelt sógradiens létrehozásával, 1,7 $\mathrm{M} \quad\left(\mathrm{NH}_{4}\right)_{2} \mathrm{SO}_{4} \quad$ kezdeti koncentrációval.

Az aktív frakciók összegyűjtése és ultraszürése után, az enzim tisztítását $50 \mathrm{mM}$ Tris/ $\mathrm{HCl}$ $\mathrm{pH}=7,2$ pufferrel egyensúlyba hozott Q-Sepharose gyantát tartalmazó ioncserélő oszlopon (1 cm x $25 \mathrm{~cm}$ ) folytattam. A megkötött fehérjéket 0-1 N NaCl sógradiens segítségével eluáltam, s sikerült egy fitáz aktivitással rendelkező csúcsot elkülönítenem.

A hidrofób kölcsönhatású kromatográfia utáni tisztítási anyagmérleget pedig a 12. táblázatban foglaltam össze.

12. táblázat A tisztítás anyagmérlege

\begin{tabular}{|l|c|c|c|c|c||}
\hline \multicolumn{1}{|c|}{ Múveleti lépések } & $\begin{array}{c}\text { Össz. } \\
\text { aktivitás (U) }\end{array}$ & $\begin{array}{c}\text { Össz. } \\
\text { fehérje (mg) }\end{array}$ & $\begin{array}{c}\text { Specifikus } \\
\text { aktivitás } \\
(\mathbf{U} / \mathbf{m g})\end{array}$ & $\begin{array}{c}\text { Kitermelés } \\
(\%)\end{array}$ & $\begin{array}{c}\text { Tisztulási } \\
\text { faktor }\end{array}$ \\
\hline Fermentlé & 1200 & 126,2 & 9,5 & 100 & 1 \\
\hline Kicsapás után & 493,9 & 35,7 & 13,8 & 41,2 & 1,5 \\
\hline $\begin{array}{l}\text { Hidrofób kölcsönhatás } \\
\text { kromatográfia }\end{array}$ & 121,8 & 4,5 & 27,0 & 10,2 & 2,8 \\
\hline $\begin{array}{l}\text { Ioncserés } \\
\text { kromatográfia }\end{array}$ & 61,5 & 0,7 & 86,7 & 5,1 & 9,1 \\
\hline
\end{tabular}

A Thermomyces lanuginosus IMI 096218 törzs által termelt fitáz enzim tisztítása során $5,1 \%$ kitermelést értem el, 9,1 tisztulási faktorral. GULATI és munkatársai (2007b) egy Thermomyces lanuginosus eredetü fitáz tisztítása során 3,44 \%-os kitermelést értek el, 40,75 tisztulási faktorral. A nagyobb tisztulási faktor utalhat arra, hogy az általuk vizsgált fitáz enzimet komposzttal kiegészített talajból izolálták, mely összetettebb kiindulási fehérje tömeget feltételez. 


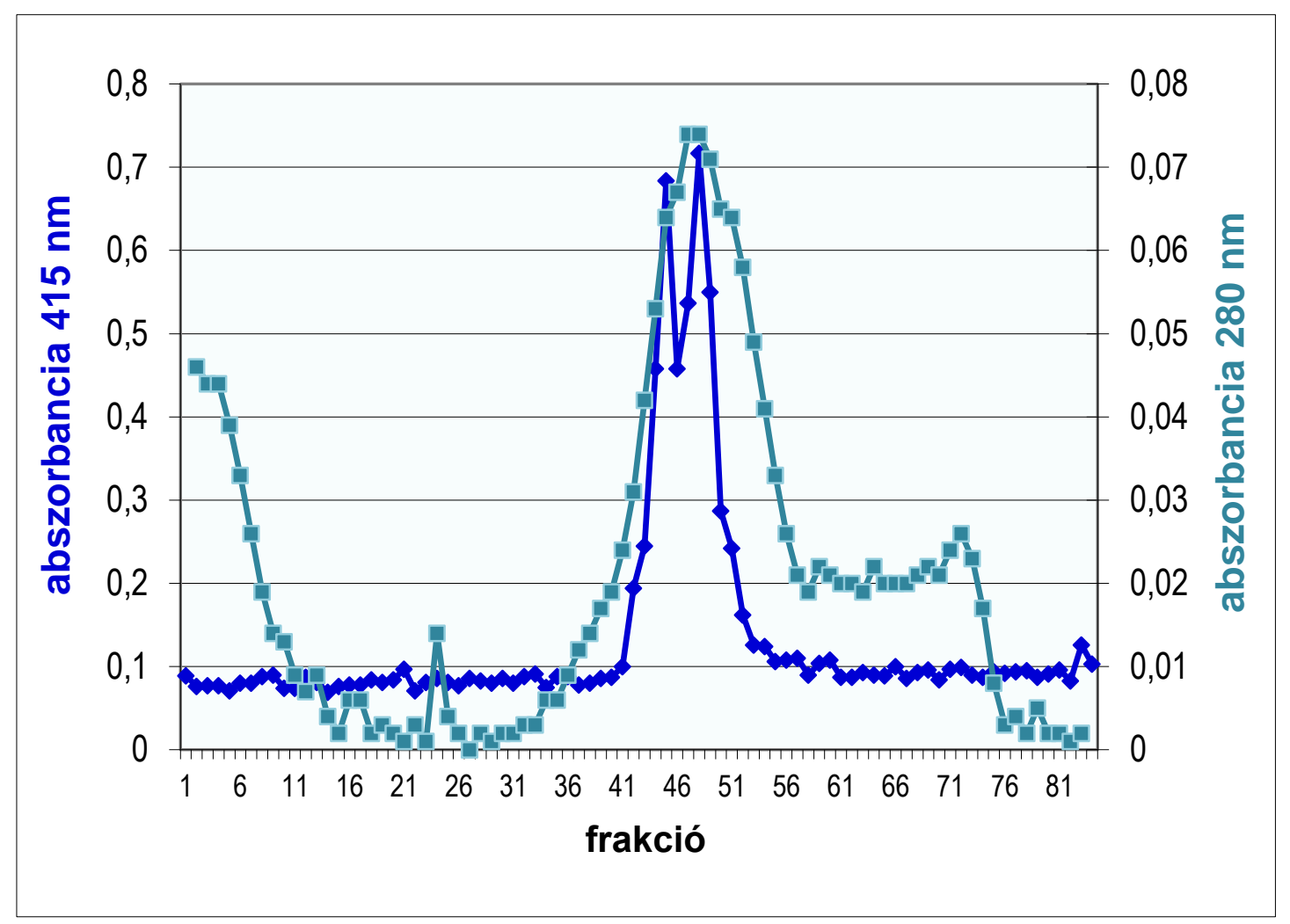

20. ábra Hidrofób kölcsönhatású kromatográfia kromatogramja

(A $415 \mathrm{~nm}$ - fitáz aktivitás, A $280 \mathrm{~nm}$ fehérje tartalom)

A szilárd szubsztrátumú búzakorpán megvalósított fermentáció során több enzimfehérje szintetizálódhatott, mely arányaiban kevesebb fitázt tartalmaz, s ez eredményezi a nagyobb tisztulási faktor elérését. Mindkét módszer alkalmas a fitáz enzim homogenitásig történő tisztítására, de megállapítható, hogy a végeredményként kapott kitermelés értékek tekintetében az általam alkalmazott módszerrel jobb kihozatal érhető el.

\subsection{A termofil Thermomyces lanuginosus eredetủ fitáz enzim jellemzése}

\subsubsection{Molekulatömeg}

A molekulatömeg meghatározása $10 \%$ akrilamidot tartalmazó gélelektroforézissel (SDSPAGE) történt. A futtatás és festés eredményeképpen egy vastagabb $60 \mathrm{kDa}$ körüli (fehérje frakció II.), s egy vékonyabb $90 \mathrm{kDa}$ körüli (fehérje frakció I.) molekulatömegü sáv különült el, melyek a 21. ábrán láthatók. A két sáv megjelenésére magyarázat lehet az, hogy az enzim dimer formájú, illetve a fitáz különböző típusai is jelen lehetnek.

A gomba eredetű fitáz enzimek, köztük az élesztőgomba eredetủek molekula tömege 39-88 kDa között található, a baktérium eredetủek 38-48 kDa körüli határok között mozognak. Ezen értékekkel hasonlóságot mutat az általam vizsgált enzim is. 


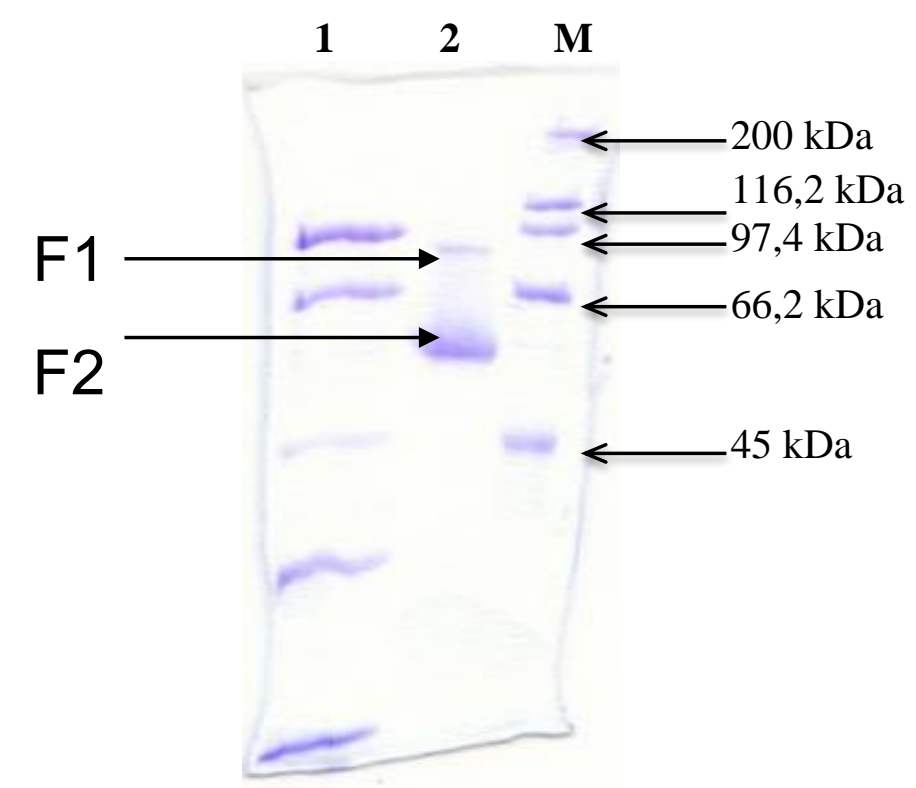

\section{1. ábra. A T. lanuginosus eredetü fitáz enzim SDS-PAGE során}

1: fehérjék az 1. lépés után, 2: F1 - Fehérje frakció I, F2 - Fehérje frakció II, M: molekulamarkerek: 200 kDa miozin; 116,2 kDa $\beta$-galaktozidáz; 97,4 kDa foszforiláz; 66,2 kDa marha szérum albumin; 45 kDa ovalbumin; 31 kDa anhidráz

A tisztítás során kapott fitáz aktivitással rendelkező fehérjének a biokémiai jellemzését a következökben mutatom be.

\subsection{2 pH optimum}

A tisztított enzimkészítmény optimális $\mathrm{pH}$-jának meghatározása $\mathrm{pH}=1,5-9$ közötti tartományban történt Na-citrát, Na-acetát és Tris-maleát/NaOH puffer rendszerek segítségével $65^{\circ} \mathrm{C}$-on történő aktivitásméréssel. Az eredményeket a 22. ábrán mutatom be, melyekből megállapítható, hogy az enzimkészítmény pH optimuma szük tartományban található. A maximális aktivitás $\mathrm{pH}=5,5$ és $\mathrm{pH}=7,5$ értékeknél mérhető. $\mathrm{A} \mathrm{pH}=5,5$ értéket biztosító pufferek - Na-acetát és Tris-maleát/ $\mathrm{NaOH}$ - mindegyikében 4500 U/1 a fitáz enzim aktivitása, míg a lúgos tartományban, pH=7,5 esetén közel $2500 \mathrm{U} / 1$ aktivitás mérhető. A diagrammon látható, hogy $\mathrm{pH}=3,5$ értéknél is 2000 U/1 értéket meghaladó az aktivitás Na-citrát pufferben, míg Na-acetát alkalmazásával csupán a harmada.

CHADHA és munkatársai (2004) Rhizomucor pusillus szilárd szubsztrátumú fermentációval előállított, részlegesen tisztított fitáz készítményt vizsgálva, optimálisnak a $\mathrm{pH}=5,4$ értéket találták, de széles $\mathrm{pH}$ tartományban $(\mathrm{pH}=3-7,8)$ a maximális aktivitásának $80 \%$-át mutatta. A méréseimmel megegyező $\mathrm{pH}=5,5$ értéket találták optimálisnak a termofil Aspergillus fumigatus, Myceliophthora thermophile és Sporotrichum thermophile (WANG et al. 2007, WYSS et al. 1999a, SINGH \& SATYANARAYANA, 2011) eredetü fitáz enzimek esetében is. 
Thermomyces lanuginosus TL-7 mutáns törzsénél és Thermoascus aurantiacus termofil gombák esetében az optimumot $\mathrm{pH}=5,0$ értéknek állapították meg (GULATI et al. 2007b, NAMPOOTHIRI et al. 2004). A Thermomyces lanuginosus egy másik törzsét vizsgálva $\mathrm{pH}=7$-nek határozták meg a fitáz enzim müködésének pH optimumát (BERKA et al. 1998). A szakirodalomban fellelhető és a kapott eredmények alapján elmondható, hogy a Thermomyces lanuginosus különböző törzsei is eltérő pH optimummal rendelkeznek, mely alátámasztja a vizsgált gombafaj széleskörü alkalmazási lehetőségeit.

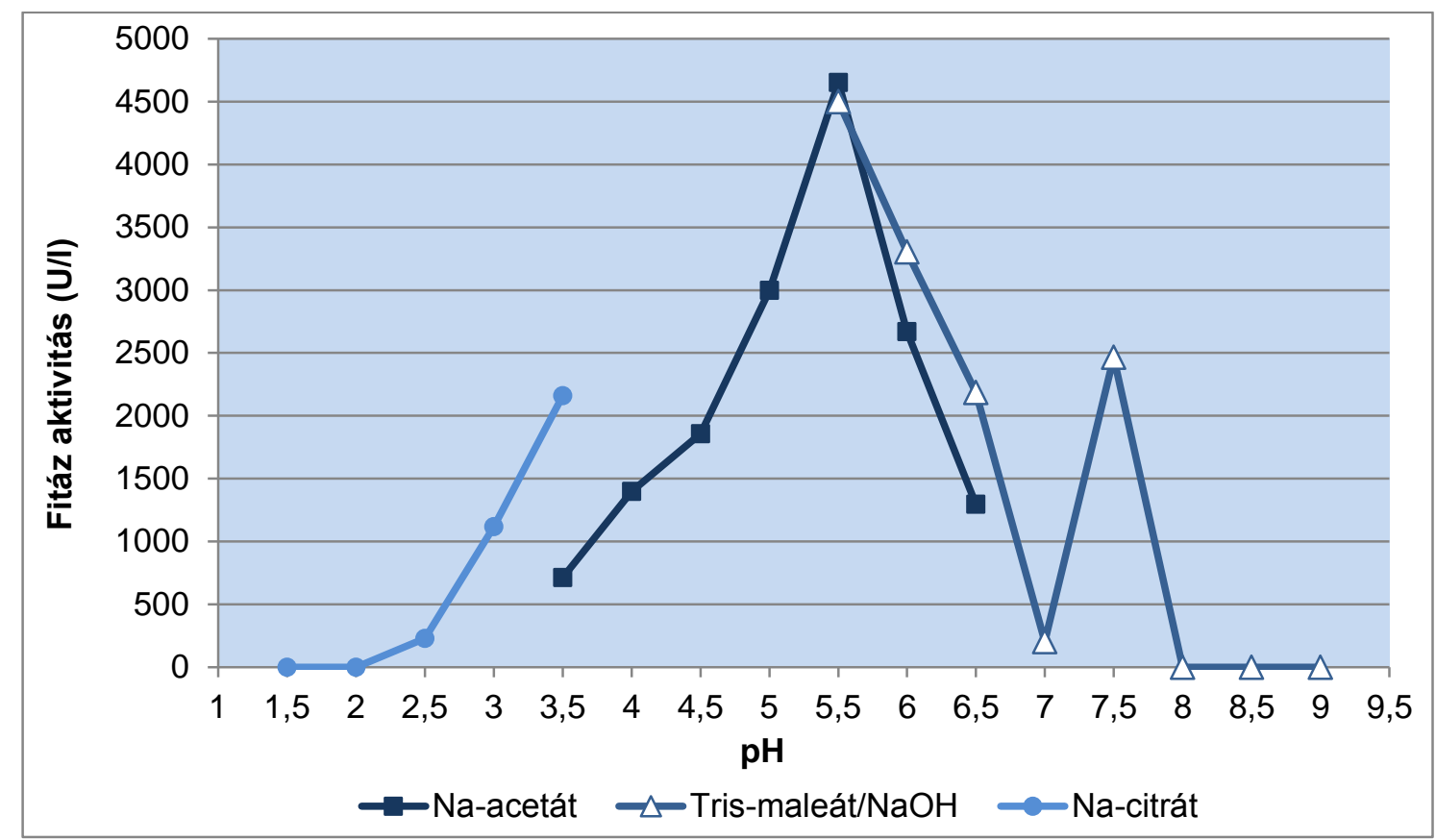

22. ábra T. lanuginosus IMI 096218 törzs eredetű fitáz enzimkészítmény pH függése $\left(65^{\circ} \mathrm{C}\right.$ on)

\subsubsection{Hőmérséklet függés}

A hőmérsékletnek az enzimkészítmény aktivitására gyakorolt hatásának vizsgálata Na-fitát szubsztrátumot is tartalmazó Na-acetát pufferben $\mathrm{pH}=5,5$ értéken történt. A hőmérsékletet $5{ }^{\circ} \mathrm{C}$ onként emelve, $35-90{ }^{\circ} \mathrm{C}$ közötti tartományban mértem az enzim aktivitását. Eredményeimet a 23. ábrán mutatom be, melyen jól látható, hogy az enzim a maximális aktivitást $70{ }^{\circ} \mathrm{C}$-on mutatja. A hőmérséklet további, $5^{\circ} \mathrm{C}$-kal történő emelésével, az aktivitás csupán $30 \%$-a marad meg.

Szintén $70^{\circ} \mathrm{C}$-on mérték a legnagyobb aktivitás értékeket CHADHA és munkatársai (2004) Rhizomисоr pusillus részlegesen tisztított fitáza esetében, majd megállapították, hogy a hőmérséklet további emelése az aktivitás drasztikus csökkenését idézi elő. A termofil gombák közül a $T$. aurantiacus $55^{\circ} \mathrm{C}$, a $S$. thermophile $60^{\circ} \mathrm{C}$ (NAMPOOTHIRI et al. 2004) és a T. lanuginosus (BERKA et al. 1998) $65^{\circ} \mathrm{C}$-on mutatta a maximális aktivitás értéket. E törzsek mindegyike kisebb hőmérséklet optimummal rendelkezett, mint az általam vizsgált T. lanuginosus IMI 096218 törzs. 
GULATI és munkatársai (2004) szintén a T. lanuginosus TL7 mutánsánál állapították meg 70 C-on a hömérséklet optimumot.

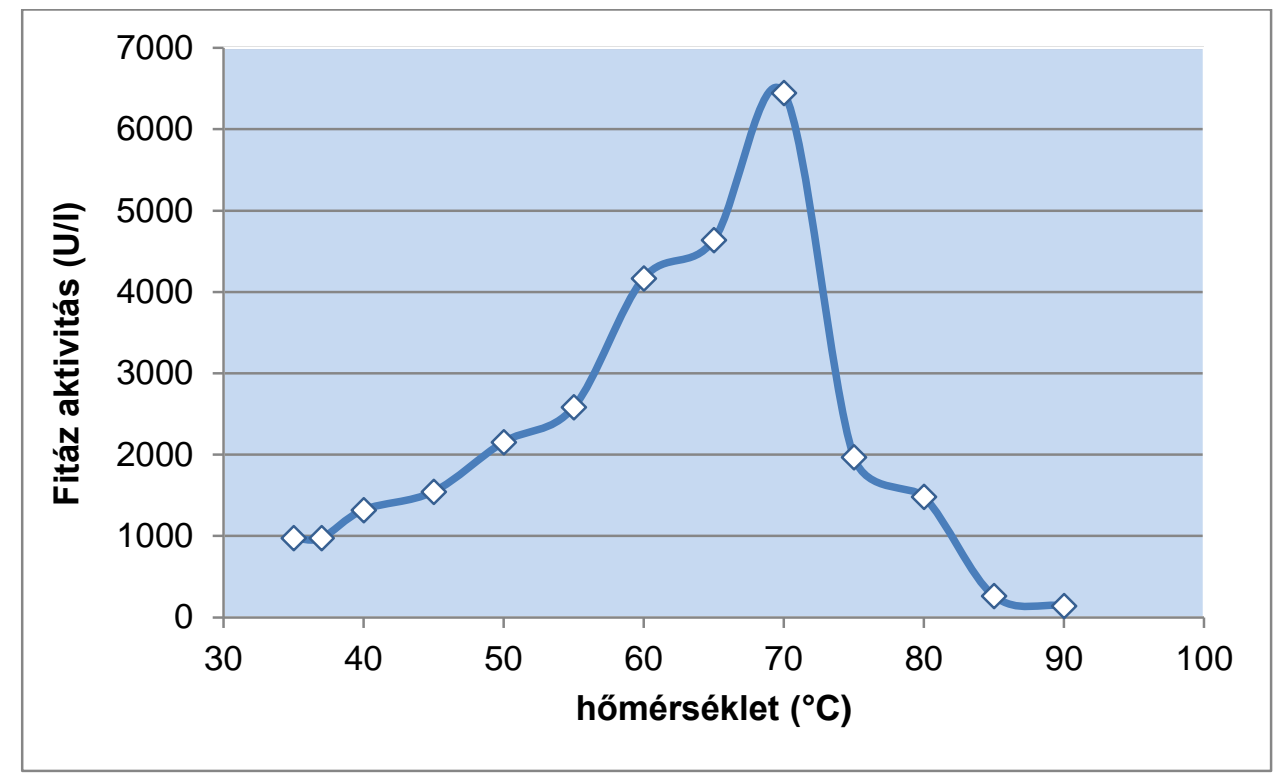

\section{3. ábra T. lanuginosus IMI 096218 fitáz készítmény hőmérséklet függése ( $\mathrm{pH}=5,5)$}

Fonalas gombák közül a legnagyobb értéket az Aspergillus fumigatus génmódosított törzsénél találták (PASAMONTES et al. 1997), mely $100{ }^{\circ} \mathrm{C}$-on is megtartotta aktivitásának $90 \%$-át 20 percig. A nagy hőmérséklet optimum, valamint a termostabilitás kívánatos tulajdonságok az állattenyésztésben alkalmazásra kerülő fitáz esetén, hisz a takarmány pelletálása során magas hőmérsékletet, akár 65-95 ${ }^{\circ} \mathrm{C}$-ot alkalmaznak (VOHRA \& SATYARAYANA 2003). Ennek alapján az általam vizsgált törzs alkalmas lehet takarmányozásban való felhasználásra is.

\subsubsection{Enzimkinetikai vizsgálatok eredményei}

Az enzimkinetikai vizsgálatok 0,2, 0,5, 1, 2 és $5 \mathrm{mM}$ koncentrációjú Na-fitát szubsztrátum alkalmazásával történtek. A reakciósebességet a keletkezett termék, azaz a felszabadult foszfor mennyiségi meghatározásával mértem. A szubsztrátum átalakítását 30 percig követtem. Mind a Lineweaver-Burk-féle kettős reciprok ábrázolással, mind a Hanes-Woolf-féle linearizálási módszerrel meghatároztam a kinetikai paramétereket. A T. lanuginosus IMI 096218 törzs fitáz enzimének kinetikai paraméterei a Lineweaver-Burk-féle módszerrel: $\mathrm{K}_{\mathrm{M}}=0,285 \mathrm{mM}, \mathrm{v}_{\max }=0,126$ $\mathrm{mM}$ /perc, míg a Hanes-Woolf-féle módszerrel: $\mathrm{K}_{\mathrm{M}}=0,312 \mathrm{mM}, \mathrm{v}_{\max }=0,132 \mathrm{mM} /$ perc. A két módszer által kapott eredmények mindkét paraméter esetén hasonlóak.

A Na-fitát szubsztrátumhoz mutatott affinitást illetően különböző kutatócsoportok által, a Lineweaver-Burk-féle linearizálási módszer alkalmazásával elért értékeket a 13. táblázatban foglaltam össze. Eredményeim hasonlóságot mutatnak A. ficuum (ZHANG et al. 2010) és A. oryzae

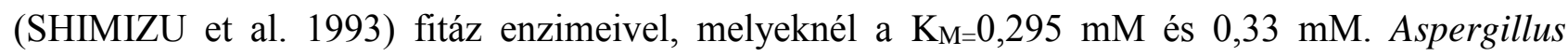


terreus eredetű fitáz enzimeknél meghatározott $\mathrm{K}_{M}$ értékek esetében jelentősebb eltérést tapasztaltam: A. terreus 9A1 törzsnél $\mathrm{K}_{\mathrm{M}}=0,0106 \mathrm{mM}$, A. terreus $\mathrm{CBS}$ törzs eredetű fitáznál pedig 0,0232 $\mathrm{mM}$ (WYSS et al. 1999 a) volt.

13. táblázat Különböző eredetű fitáz enzimek kinetikai paraméterei Na-fitát

szubsztrátumon (Lineweaver-Burk féle linearizálási módszer)

\begin{tabular}{|l|l|c|l|}
\hline \multicolumn{1}{|c|}{$\begin{array}{c}\text { Termelö } \\
\text { mikroorganizmus }\end{array}$} & $\boldsymbol{K}_{\boldsymbol{M}}$ érték $(\mathbf{m M})$ & \multicolumn{1}{c|}{$\boldsymbol{v}_{\text {max }}$} & \multicolumn{1}{c|}{ Hivatkozás } \\
\hline A. ficuum & 0,295 & $55,9 \mathrm{nmol} / \mathrm{perc}$ & ZHANG et al. 2010 \\
\hline A. oryzae & 0,33 & - & SHIMIZU et al. 1993 \\
\hline A. terreus 9A1 & 0,0106 & - & WYSS et al. 1999 a \\
\hline A. terreus CBS & 0,0232 & - & WYSS et al. 1999 a \\
\hline A. niger ATCC 9142 & 0,1 & $0,833 \mu \mathrm{Mm} / \mathrm{perc}$ & GULATI et al. 2007b \\
\hline T. lanuginosus TL-7 & 0,00455 & $\begin{array}{l}5,018 \mu \mathrm{mol} / \mathrm{perc} / \mathrm{mg} \\
1,671 \mu \mathrm{mol} / \mathrm{perc} / \mathrm{mg}\end{array}$ & SONI és KHIRE, 2010 \\
\hline A. niger NCIM 563 & $\begin{array}{l}\text { Phy I 2,01 } \\
\text { Phy II 0,145 }\end{array}$ \\
\hline
\end{tabular}

\subsubsection{Stabilitási vizsgálatok}

A fitáz enzim stabilitását különböző hőmérsékleten $\left(55^{\circ} \mathrm{C}, 60^{\circ} \mathrm{C}, 65^{\circ} \mathrm{C}\right)$ és $\mathrm{pH}$ értékeken $(\mathrm{pH}=3,5-7,5)$ vizsgáltam aktivitás mérésen keresztül. Minden adott hőmérsékleten megmértem az enzim aktivitásának alakulását különböző $\mathrm{pH}$ értékeken. Az eredményeket az idő függvényében ábrázolva meghatároztam az enzim felezési idejét, valamint a kezdeti inaktiválódási sebességet. Az adatok értékelésére STATISTICA 9.0 programcsomag segítségével válaszfelületi módszert alkalmaztam, melynek eredményeként a felezési idő, valamint az inaktiválódás sebessége másodfokú teljes polinom modellel írható le:

Felezési idő $=\mathbf{- 2 3 2 9}, 26+62,58 x+283,24 y-0,50 x^{2}-2,09 x y-12,92 y^{2}$

(24. ábra)

Inaktiválódási sebesség $=\mathbf{- 9 7 , 1 5 + 3 , 1 9 x}+\mathbf{2 , 7 1 y - 0 , 2 9} \mathrm{x}^{2}+\mathbf{0 , 0 0 5 x y - 0 , 2 6 y ^ { 2 }}$

(25. ábra)

ahol x: hőmérséklet, y: pH.

Az adatokból olyan kétdimenziós mátrixot képeztem (24. ábra), melyen jól látható az enzim felezési ideje a $\mathrm{pH}$ és a hőmérséklet függvényében. Az adott hőmérséklet és pH értékeknek megfelelően a modell segítségével kiszámoltam a felezési időket (14. táblázat). 


\section{4. táblázat A polinom modellel számolt felezési idők a pH és a hőmérséklet függvényében}

\begin{tabular}{c|ccccccccc}
\hline & \multicolumn{10}{c}{ FELEZÉSI IDŐ (perc) } \\
\hline $\begin{array}{c}\text { Hőmérséklet } \\
{ }^{\circ} \mathbf{C}\end{array}$ & $\mathbf{3 , 5}$ & $\mathbf{4}$ & $\mathbf{4 , 5}$ & $\mathbf{5}$ & $\mathbf{5 , 5}$ & $\mathbf{6}$ & $\mathbf{6 , 5}$ & $\mathbf{7}$ & $\mathbf{7 , 5}$ \\
\hline $\mathbf{5 5}$ & 31 & 67 & 96 & 119 & 135 & 145 & 148 & 145 & 136 \\
$\mathbf{6 0}$ & 20 & 50 & 74 & 92 & 103 & 107 & 106 & 97 & 83 \\
$\mathbf{6 5}$ & 0 & 9 & 28 & 40 & 46 & 45 & 38 & 25 & 5 \\
\hline
\end{tabular}

Felezés idố perc $=-2329,2634+62,5833^{*} x+283,243^{*} y-0,5035^{*} x^{*} x-2,0854^{*} x^{*} y-12,9219^{*} y^{*} y$

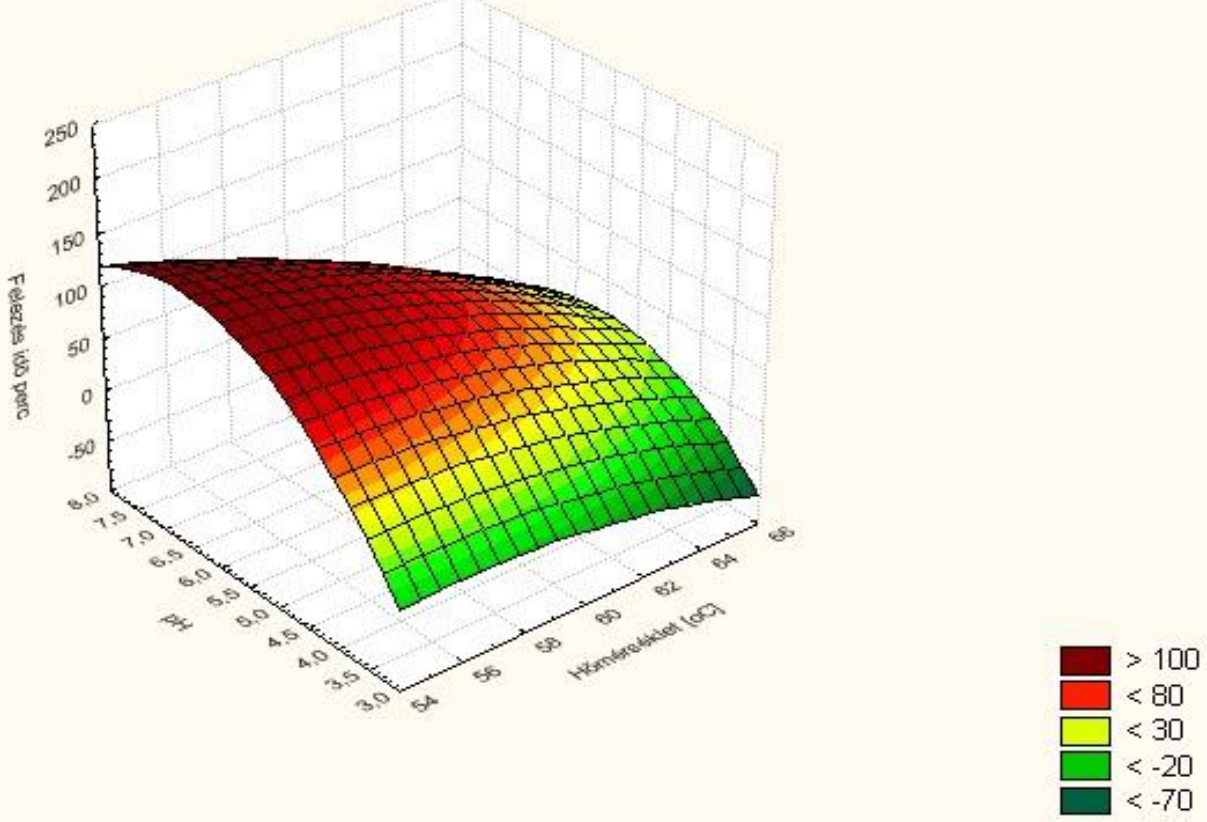

\section{4. ábra Fitáz enzim felezési ideje (perc) a pH és a hőmérséklet függvényében}

Megállapítható, hogy a vizsgált hömérsékletek közül az enzim $55^{\circ} \mathrm{C}$-on a legstabilabb. A $\mathrm{pH}$ optimum meghatározásánál $\mathrm{pH}=5,5$, illetve $\mathrm{pH}=7,5$ értékeken mértem a legnagyobb aktivitásokat, s megfigyelhető, hogy $55^{\circ} \mathrm{C}$-on e két pH érték között közel azonosak a stabilitás mértékét jelző felezési idők is: (135-148 perc). $\mathrm{Az}$ enzim $54-58{ }^{\circ} \mathrm{C}$ között, $\mathrm{pH}=5,0-7,5$ tartományban a legstabilabb, felezési ideje több mint 100 perc. A hőmérséklet emelésével azonban az enzim stabilitása csökken, különösen ha a pH a semlegestöl az enyhén savas irányba változik. $60^{\circ} \mathrm{C}$-on $\mathrm{pH}=6-6,5$ értéken a felezési idő $107-106$ perc, míg $65^{\circ} \mathrm{C}$-on $\mathrm{pH}=5,5-6,0$ esetén $46-45$ percesek a felezési idők. Ezen a hőfokon, $\mathrm{pH}=3,5$ értéken már nincs mérhető aktivitás.

A 25. ábrán látható kezdeti inaktiválódási sebességek eredményei alapján is megállapítható, hogy $\mathrm{pH}=5-6,5$ közötti tartományban, 54 és $58{ }^{\circ} \mathrm{C}$ között csökken legkevésbé az aktivitása az enzimnek. Savas tartományban, $\mathrm{pH} 3,5$ alatt illetve $62^{\circ} \mathrm{C}$ hömérséklet felett gyorsabb az inaktiválódás. 


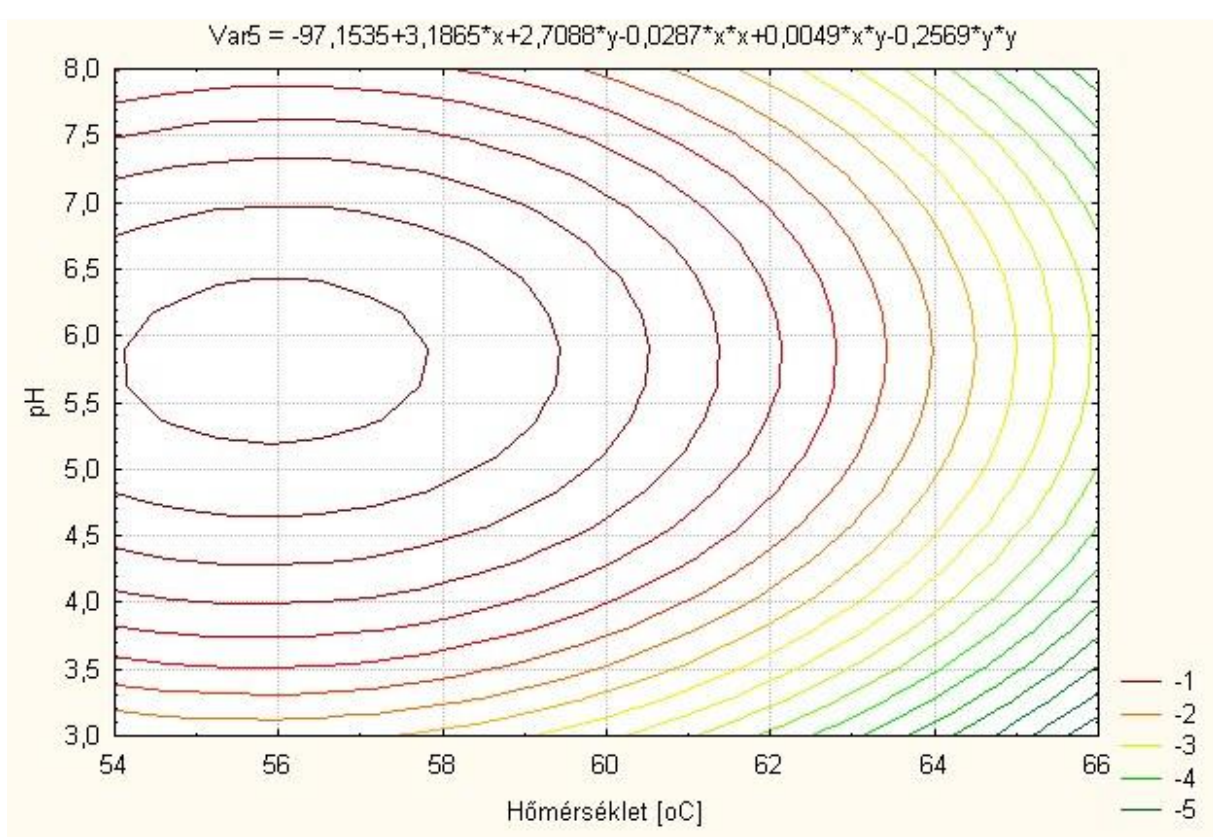

25. ábra Thermomyces lanuginosus fitáz enzimének kezdeti inaktiválódási sebessége (U/perc) a pH és hőmérséklet függvényében

GULATI és munkatársai (2007b) a T. lanuginosus TL-7 mutáns fitáz enzimének jellemzése során az enzim hő- és $\mathrm{pH}$ stabilitását is vizsgálva megállapították, hogy a $\mathrm{pH}=5$ optimum ellenére, pH=7 értéken stabilabb az enzim. SINGH és SATYANARAYANA (2009) a Sporotrichum thermophile eredetü fitáz termostabilitását vizsgálták. Eredményeik szerint az enzim aktivitásának $100 \%$-át megörizte $60^{\circ} \mathrm{C}$-on történő inkubálás során 5 órán keresztül, s felezési ideje 16 óra, míg $80{ }^{\circ} \mathrm{C}$-on a felezési idő 90 perc volt. ZHOU és munkatársai (2006) Neurospora crassa Ncphy fitáz enzimet kódoló génjét klónozták és kifejeztették Pichia pastoris-ban. Ezzel egy termostabil enzimet kaptak, mely $80{ }^{\circ} \mathrm{C}$-on megörizte aktivitásának $76 \%$-át 10 percig, $58 \%$-át 20 percig, és $43 \%$-át 60 percig. Az általam vizsgált enzim hőstabilitása elmaradt mind a mutáns, mind a genetikailag módosított törzs eredetű fitázoknál kapott értékektől.

\subsubsection{Fémionok hatása az enzimaktivitásra}

A különböző fémionok hatását az enzim aktivitására $5 \mathrm{mM}$ koncentrációban, a $\mathrm{Fe}^{2+}$ és $\mathrm{Fe}^{3+}$ ionok esetében $1 \mathrm{mM}$ koncentrációban vizsgáltam. Eredményeimet a 26. ábrán mutatom be, melyen a relatív aktivitásokat tüntettem fel, $100 \%$-nak tekintve a fémion kiegészítés nélkül mért kontroll minta aktivitását. $\mathrm{A} \mathrm{Fe}{ }^{2+}, \mathrm{K}^{+}, \mathrm{Ca}^{2+}, \mathrm{Fe}^{3+}$ és $\mathrm{Mg}^{2+}$ esetén az aktivitás értékek 13-22\%-os növekedését mértem, tehát ezek az ionok kismértékben fokozzák az enzim müködését.

Eredményeimmel ellentétben Wyss és munkatársai (1999) megállapították, hogy különböző gombák (A. fumigatus, E. nidulans, A. niger, A. terreus) esetén a $\mathrm{Fe}^{2+}, \mathrm{Fe}^{3+}$ ionok inhibitorként hatnak - 1 mM-os koncentrációban - a fitáz enzim müködésére. Csakúgy, mint a $\mathrm{Cu}^{2+}$ és $\mathrm{Mn}^{2+}$ 
ionok, melyek gátló hatását megerösítettem a T. lanuginosus IMI 096218 törzs fitáz enzime esetében is, ahol közel $70 \%$ aktivitás csökkenést tapasztaltam $\mathrm{Cu}^{2+}$ ionok, s $20 \%$-ot $\mathrm{Mn}^{2+}$ jelenlétében. Emellett a $\mathrm{Zn}^{2+}, \mathrm{Ag}^{+}, \mathrm{Co}^{2+}$ ionok is gátolták a fitáz müködését, jelenlétükben a maradék aktivitás $55 \%, 49 \%$ és $38 \%$ volt. A T. lanuginosus IMI 096218 törzs fitáz enzimének aktivitására a $\mathrm{Na}^{+}$nincs hatással.

Pichia pastoris élesztőben kifejeztetett Neurospora crassa fitáz esetén (ZHOU et al. 2006) a $\mathrm{Cu}^{2+}$ ionok már $1 \mathrm{mM}$ koncentrációban is gátolták, míg a $\mathrm{Ca}^{2+}, \mathrm{Mg}^{2+}, \mathrm{Fe}^{2+}, \mathrm{Co}^{2+}, \mathrm{Mn}^{2+}, \mathrm{Zn}^{2+}$ nem befolyásolták szignifikánsan az enzim aktivitását.

Ezzel ellentétben a Thermomyces lanuginosus TL-7 mutáns törzs fitázának aktivitását a $\mathrm{Cu}^{2+}$ ionok nem gátolták, azonban a $\mathrm{Ca}^{2+}, \mathrm{Mg}^{2+}, \mathrm{Fe}^{2+}, \mathrm{K}^{+}, \mathrm{Mn}^{2+}, \mathrm{Na}^{+}, \mathrm{Ba}^{+}, \mathrm{Zn}^{2+}$ ionok mindegyike csökkentette 5 mM-os koncentrációban alkalmazva (GULATI et al. 2007).

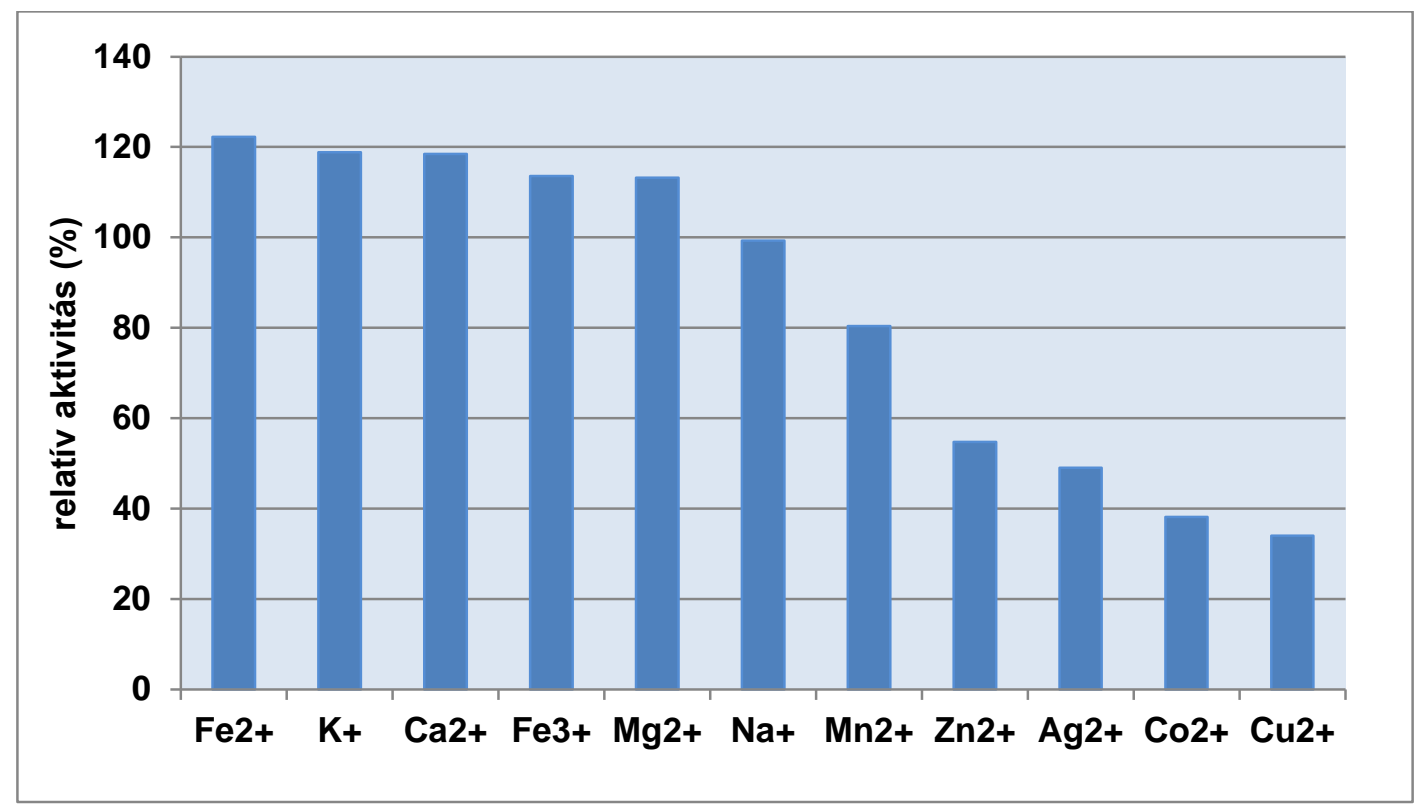

26. ábra Különböző fémionok hatása a $T$. lanuginosus fitáz enzim aktivitására (Koncentráció: $5 \mathrm{mM}, \mathrm{Fe}^{2+}$ és $\mathrm{Fe}^{3+}$ esetén $1 \mathrm{mM}$ )

A mutáns törzs fitáz enzimének legnagyobb mértékủ csökkenését a $\mathrm{Mg}^{2+}$ jelenlétében mérték, míg az általam vizsgált törzsnél a $\mathrm{Mg}^{2+}$ alkalmazása során az aktivitás $13 \%$-kal növekedett. A Sporotrichum thermophile fitáz enzimének serkentését is csupán $\mathrm{Mg}^{2+}$ ion alkalmazásával érték el, míg a többi vizsgált ion gátló hatást mutatott $5 \mathrm{mM}$ koncentrációban alkalmazva. Esetükben a $\mathrm{Zn}^{2+}$ és $\mathrm{Fe}^{3+}$ ionok gátolták leginkább az enzim müködését, 40-60\% aktivitás csökkenést idézve elő (SINGH \& SATYANARAYANA 2009), hasonlóan a T. lanuginosus IMI 096218 törzs fitáz enzime esetén mértekhez, ahol a relatív aktivitás 55\%-ra csökkent $\mathrm{Zn}^{2+}$ jelenlétében.

Eredményeim arra utalnak, hogy a gátló hatás alakulása az alkalmazott koncentráció mellett jelentős mértékben függ a mikroba, illetve azonos mikroorganizmus esetén az egyes törzsek genetikai felépítésétől. A két Thermomyces lanuginosus törzs - IMI 096218 és a TL-7 mutáns 
(GULATI et al. 2007) - fitáz enzimének aktivitását az egyes fémionok jelentős eltérésekkel befolyásolják, éppen ezért a gyakorlati alkalmazás szempontjából fontos meghatározni minden törzs esetén a fémionok hatását is.

A T. lanuginosus IMI 096218 törzs esetében a $\mathrm{Ca}^{2+}$ az enzim müködését fokozta, a kontroll mintához képest $18 \%$-os aktivitás növekedést határoztam meg. $\mathrm{A} \mathrm{Ca}^{2+}$ ionnak jelentős szerepe van az enzim müködésében, különösen a $\beta$-propeller fitázok esetén, melyek elsősorban Bacillus fajokból izolálhatók. Bacillus amyloliquefaciens DS11 termostabilis fitáz enzimével végzett vizsgálatok során megállapították, hogy $\mathrm{Ca}^{2+}$ jelenléte szükséges a fitátok hidrolíziséhez, ugyanis az enzim aktiválása az aktív centrumban megkötött kalcium ionnal kezdődik. A szubsztrátumnak is szükséges $\mathrm{Ca}^{2+}$ iont tartalmaznia, mert e fitáz csak a kalcium-fitát komplexet képes hidrolizálni. Valójában mind a feleslegben jelenlévő $\mathrm{Ca}^{2+}$, mind a felesleges szabad fitát, amelyek nem lépnek komplexbe egymással, kompetitív inhibitorként szolgálnak (OH et al. 2001). A Thermomyces lanuginosus eredetű fitáz enzim kristályszerkezete még nem ismert, napjainkig lipáz (BROZOZOWSKI \& SAVAGE, 2000) és xilanáz (GRUBER et al. 1998) enzimei esetében történt szerkezet meghatározás.

\subsection{Mezofil Aspergillus eredetü fitáz enzim fermentáció}

\subsubsection{Törzsszelekció}

A fitáz enzim fermentációjához tizenegy Aspergillus törzs szelekcióját is elvégeztem $5(\mathrm{w} / \mathrm{v}) \%$ rizsliszt tartalmú tápközegen. Eredményeim a 27. ábrán láthatók. A legjobb fitáz aktivitást az A. niger F00735 törzs mutatta, melynél az 5. napon az aktivitás 665 U/1 volt.

Az aktivitás folyamatos növekedését tapasztaltam még az A. awamori F00030, az A. niger F00714, F00722, F00720 és F00770 törzsek esetén is, míg a többi vizsgált törzsnél a 4. napon volt maximális az enzimtermelés. A fitáz termelésre irányuló további optimálási kísérleteimhez az $A$. niger F00735 törzset választottam. 


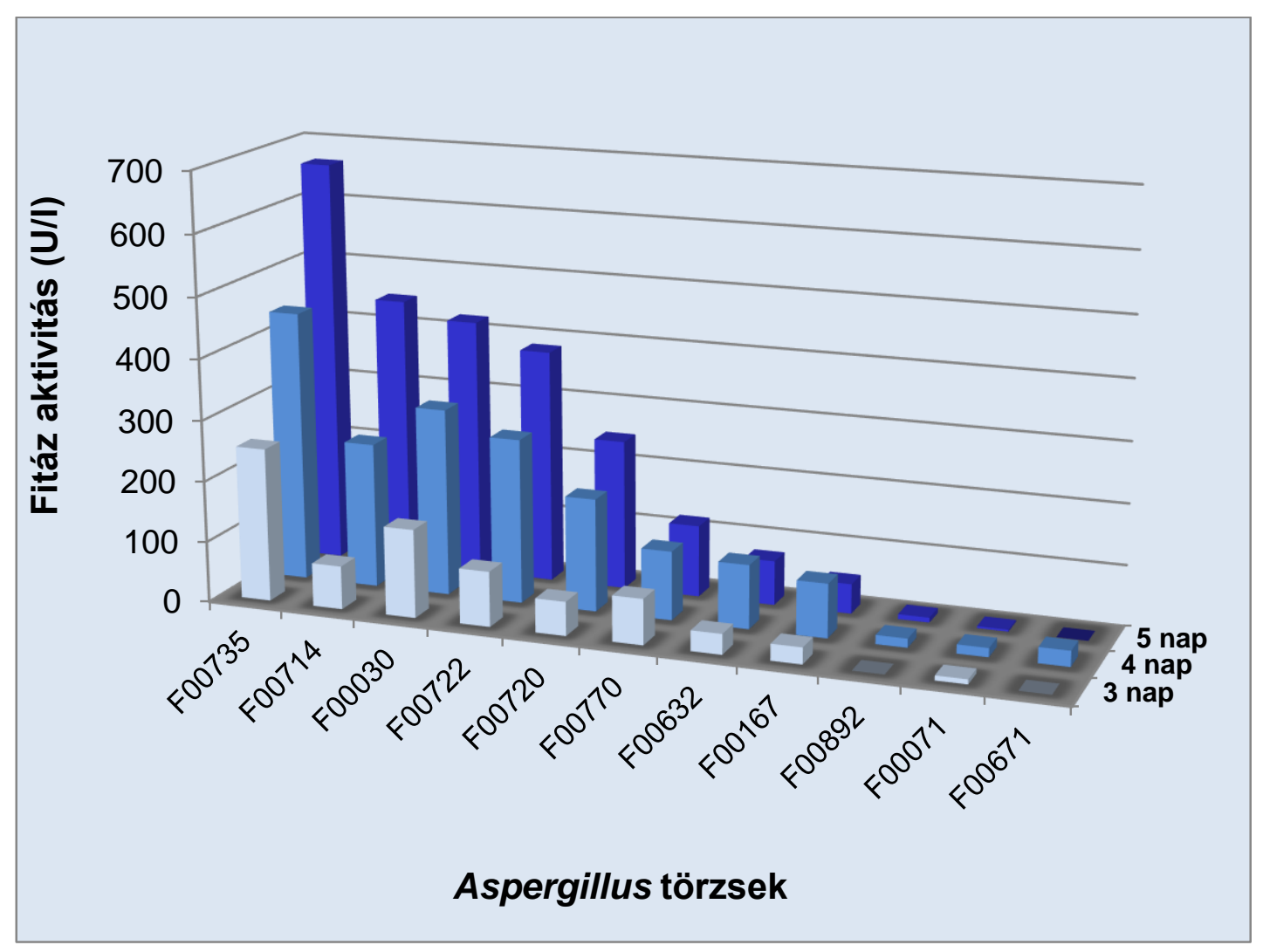

27. ábra Aspergillus törzsek rangsorolása fitáz aktivitásuk alapján $\left(5 \%\right.$ rizslisztes tápközeg, $\left.28^{\circ} \mathrm{C}, 220 \mathrm{rpm}\right)$

\subsubsection{Tápközeg összetétel optimálása}

\subsubsection{Szénforrás hatása}

Az Aspergillus niger F00735 törzs jó növekedést mutat PDA vagy Czapek agaron, azonban a Czapek agar foszfor tartalmának csökkentésével - mely az enzimtermelés fokozását célozza - a biomassza mennyisége is csökken. Ez is bizonyítja, hogy mind a szénforrás, mind a foszfor forrás meghatározó szerepet játszik a gombák növekedésében. Különböző természetes szubsztrátumok (rizsliszt, borsóliszt, kukoricaliszt, kukoricakeményítő, kukoricadara, szójaliszt, búzaliszt és búzadara) alkalmazásával vizsgáltam a fitáz termelés alakulását A. niger F00735 törzsnél egy hetes fermentáció során, s a kapott eredményeket a 28. ábrán mutatom be.

A vizsgált természetes szubsztrátumok közül a rizsliszt tartalmú tápközegben mértem a legnagyobb aktivitást, míg szójaliszten és kukoricadarán csekély fitáz termelés volt kimutatható. Búzadara, kukoricaliszt, árpaliszt, búzaliszt és kukoricadara esetén az enzimtermelés folyamatosan növekedett a 7. napig. Mivel rizsliszt esetén már a 6. napon maximális volt az enzimtermelés (1118 U/1), gazdaságossági szempontokat figyelembe véve, a fermentáció további követését már nem tartottam szükségesnek. Irodalmi adatok alapján, szintén 6-8 napos fermentációval érték el a maximális fitáz aktivitást A. niger termelő törzs alkalmazásával kukoricakeményítő tartalmú tápközegben (CASEY \& WALSH 2004; GARGOVA \& SARIYSKA 2003). Bár az Aspergillus sp. 
5990 eredetü fitáz és foszfatáz aktivitása már a 4. napon elérte maximumát, s annak ellenére, hogy a sejttömeg és a fehérje koncentráció változatlanul növekedett, további aktivitás növekedés nem volt tapasztalható a fermentáció 8. napjáig (KIM et al. 1999).

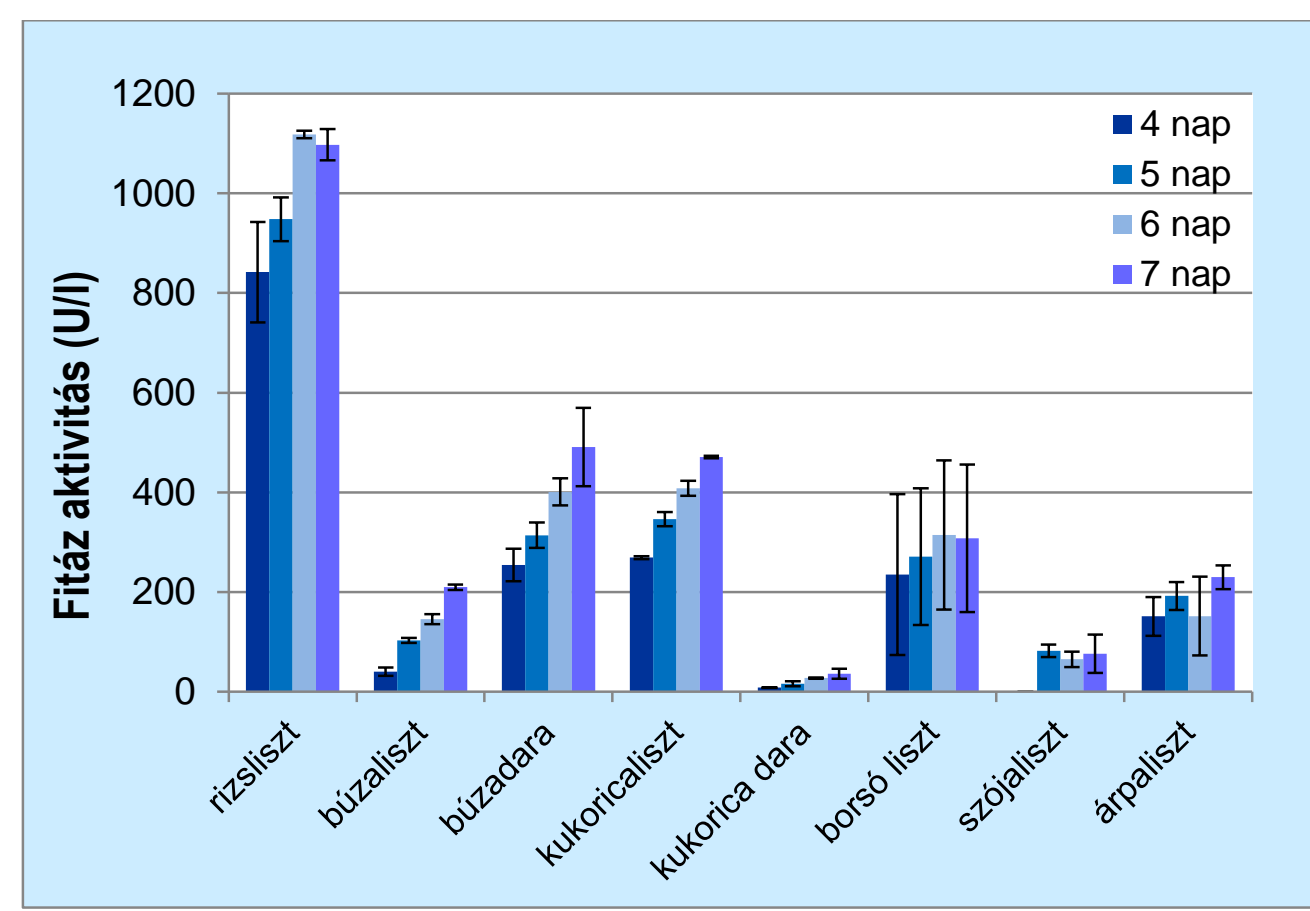

28. ábra. Különböző természetes szubsztrátumok hatása az A. niger F00735 fitáz aktivitására (5\% koncentráció, $\left.28^{\circ} \mathrm{C}, 220 \mathrm{rpm}\right)$

Vizsgálataim alapján kukoricaliszten megvalósított fermentációnál csupán max. 500 U/1 az aktivitás, mely kb. a fele a rizsliszten mért értékeknek, kukoricadarán pedig a $10 \%$-át sem éri el (50-80 U/l). GARGOVA és munkatársai (2006) 5 (w/v) \% kukoricakeményítő tartalmú tápközegben A. niger 307 törzs alkalmazásával 324 nkat/mL (190 U/l) enzimaktivitást mértek. Eredményeim alapján azt tapasztaltam, hogy a nagyobb fitinsav tartalmú fermentációs tápközeg (kukoricaliszt, búzadara, rizskorpa) alkalmazásával kisebb fitáz termelés érhető el.

Egyes kutatócsoportok az egyszerü cukrok alkalmazásával értek el hatékony fitáz termelést: SONI és KHIRE (2007) a glükózt és a fruktózt találták a legjobb szubsztrátumnak a könnyen metabolizálható cukrok közül A. niger NCIM 563 törzs fitáz termelésének vizsgálatakor. EBUNE és munkatársai (1995) A. ficuum esetén a maximális fitáz termelést 5,2\% glükóz koncentrációnál tapasztalták. $2 \%$ glükóz, illetve $2 \%$ galaktóz tartalmú tápközegen követve a fitáz aktivitás alakulását, csekély mértékü enzimtermelést tapasztaltam. Az enzimtermelés indukálhatóságát vizsgálandó a glükóz és galaktóz tartalmú fermentációs tápközegeket $1 \%$ nátrium-fitáttal egészítettem ki, valamint a nátrium-fitátot önmagában is alkalmaztam szubsztrátumként. A nátriumfitát egyedüli szénforrásként való alkalmazásával készített tápközegekben nem detektáltam fitáz aktivitást. Az egyszerü cukrokat és nátrium-fitátot tartalmazó tápközegen az aktivitás az 5. napon 
haladta meg a Na-fitát kiegészítés nélküli közegben mért aktivitás értékeket, azonban a komplexebb $2 \%$ rizsliszt tartalmú tápközegen többmint $10-15$-szeres volt az enzimaktivitás.

GARGOVA \& SARIYSKA (2003), valamint CASEY \& WALSH (2004) kutatásaik során nem tapasztalták a Na-fitát indukáló hatását. A fitáz csökkenés összefüggésben lehet az enzim szintézis foszfor gátlásával. E jelenség magyarázatául szolgálhat, hogy a fitáz gén kifejeződését a szervetlen foszfor jelenléte befolyásolja. SHIEH és munkatársai (1969) megfigyelései alapján a gomba extracelluláris fitáz termelését indukálja a tápközegben lévő limitáló szervetlen foszfát koncentráció. Fitát tartalmú szintetikus tápközeget alkalmazva egyedüli foszfor forrásként nehéz megmondani, hogy az enzim termelést a fitát indukálja, vagy a foszfor hiánya (KEROVUO 2000).

Összességében megállapítható, hogy a rizsliszt fitát tartalma $(\approx 5 \mathrm{mg} / \mathrm{g}$ azaz $250 \mathrm{mg} / \mathrm{l}$ tápközeg) elegendő a fitáz termeléshez. Rizsalapú fitáz enzim fermentációról a szakirodalomban igen kevés információ található. FUJITA és munkatársai (2001) a japán szaké készítésekor Aspergillus oryzae (KL-38) fitáz termelő mutánssal készített rizs kojit is alkalmaztak, tápanyag kiegészítésként. Továbbá az Aspergillus fitáz enzimének alkalmazása következtében növekedett az élesztő hozam, s az alkoholos fermentáció hatékonysága.

\subsubsection{Nitrogén forrás hatása}

A legkedvezőbb szénforrás kiválasztása mellett fontosnak tartottam azon nitrogénforrás kiválasztását, mellyel a rizsliszt tartalmú közegben a legnagyobb fitáz aktivitás érhető el. A két legalapvetőbb nitrogénforrást a nitrátok és az ammóniumsók jelentik a gombák számára, hiszen ezek koncentrációja a természetes környezetben is igen jelentős lehet. Ennek megfelelően a nátrium-nitrát $(8,6 \mathrm{~g} / \mathrm{l})$ helyett - azonos nitrogéntartalom beállításával - vizsgáltam az ammóniumacetátot (7,81 g/l), az ammónium-szulfátot (6,69 g/l), illetve egy szerves nitrogén forrást, a karbamidot (3,04 g/l). Fermentációs kísérletem eredményeit a 29. ábrán foglaltam össze. 


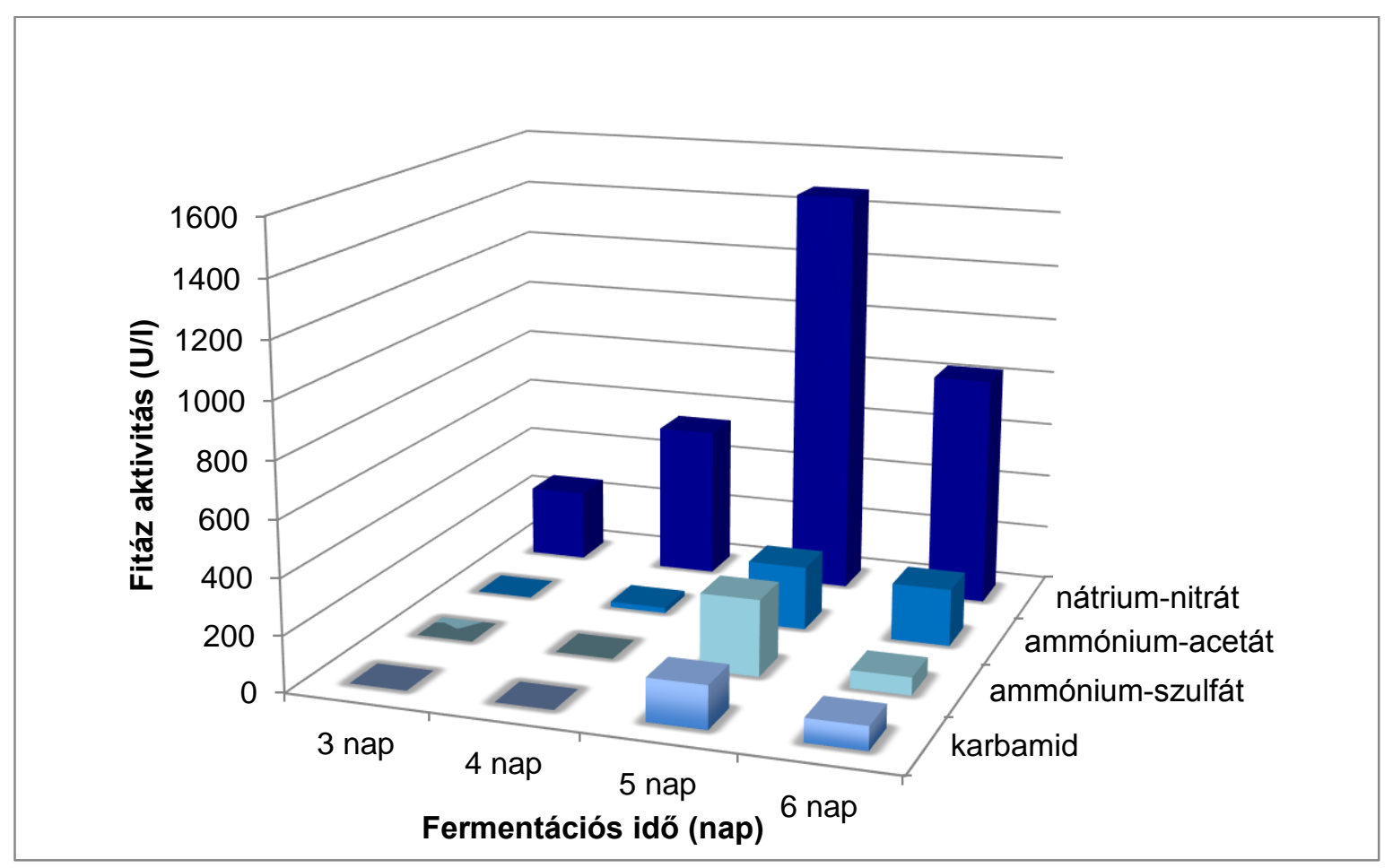

\section{9. ábra Különböző nitrogénforrások hatása az Aspergillus niger F00735 törzs fitáz} szintézisére $\left(28^{\circ} \mathrm{C}, 220 \mathrm{rpm}\right)$

A legkedvezőbb nitrogénforrásnak a nátrium-nitrát bizonyult 1400 U/1 feletti kimagasló értékkel, míg ammónium-acetáton 230 U/1, ammónium-szulfáton 274 U/1 maximális fitáz aktivitást mértem az 5. napon. A szerves nitrogénforráson, a karbamidon a törzs gyengén szaporodott, a maximális fitáz aktivitás csupán $153 \mathrm{U} / 1$ volt. Az ammóniumionok esetében mért alacsonyabb értékek oka lehet a savas közeg, mely a gomba ammóniumion felhasználásának következménye. Eredményeim alapján az alkalmazott fermentációs tápközeg nitrogénforrásaként a nátrium-nitrát megfelelő, hasonlóan számos Aspergillus niger eredetű fitáz fermentáció esetén tapasztaltakkal (GARGOVA et al. 2006, SARIYSKA et al. 2005, BHAVSAR et al. 2011).

\subsubsection{A szén- és nitrogénforrások optimális koncentrációjának meghatározása}

Az A. niger F00735 törzzsel megvalósított fitáz enzim fermentáció fitáz hozamának növelése céljából központi elrendezésű kísérlettervezési módszert használtam, a rizsliszt és a nátrium-nitrát optimális koncentrációjának megállapítására. A központi pontok: $5(\mathrm{w} / \mathrm{v}) \%$ rizsliszt és 0,86 (w/v)\% Na-nitrát, a következő léptéktényezők alkalmazásával: 1,5 (w/v)\% a rizsliszt és $0,2(\mathrm{w} / \mathrm{v}) \%$ a Nanitrát esetén.

A kísérleti eredmények értékelése Statistica 9 programcsomag segítségével történt, a modell megfelelőségét variancia analízissel elemeztem (ANOVA), melynek segítségével a következő másodfokú polinom modellt kaptam: 


$$
z=-846-634 x+50 x^{2}+7712 y-5510 y^{2}+273 x y
$$

ahol: $\quad z$ fitáz aktivitás a 6 . napon (U/1)

$x$ rizsliszt koncentrációja $(\mathrm{w} / \mathrm{v}) \%$

$y$ nátrium-nitrát koncentrációja $(\mathrm{w} / \mathrm{v}) \%$

A 30. ábrán látható kétdimenziós hatásfelületről meghatározhatók a maximális aktivitás eléréséhez tartozó rizsliszt és Na-nitrát koncentrációk. $\mathrm{A} \mathrm{NaNO}_{3}$ mennyiségének növelése vagy csökkentése nem eredményezi a fitáz termelés fokozását, így mennyisége a központi pontként választott érték: $0,86(\mathrm{w} / \mathrm{v}) \% \mathrm{NaNO}_{3}$, optimális a fitáz termeléshez. Az adott központi elrendezésű kísérlettervezési módszerrel meghatározott rizsliszt koncentráció, mely a legnagyobb fitáz aktivitást eredményezi: $7,1(\mathrm{w} / \mathrm{v}) \%$. Összességében a 0,86 (w/v)\% Na-nitrát mellett 7,1 (w/v)\% körüli rizsliszt koncentráció alkalmazásával 1500 U/1 fitáz aktivitás várható a fermentáció 6. napján. Bár a rizsliszt koncentrációjának növelése az optimális $\mathrm{NaNO}_{3}$ koncentráció mellett az aktivitás növekedését eredményezné, szubmerz körülmények között a további emelés nem megvalósítható a közeg erősen viszkózus volta miatt.

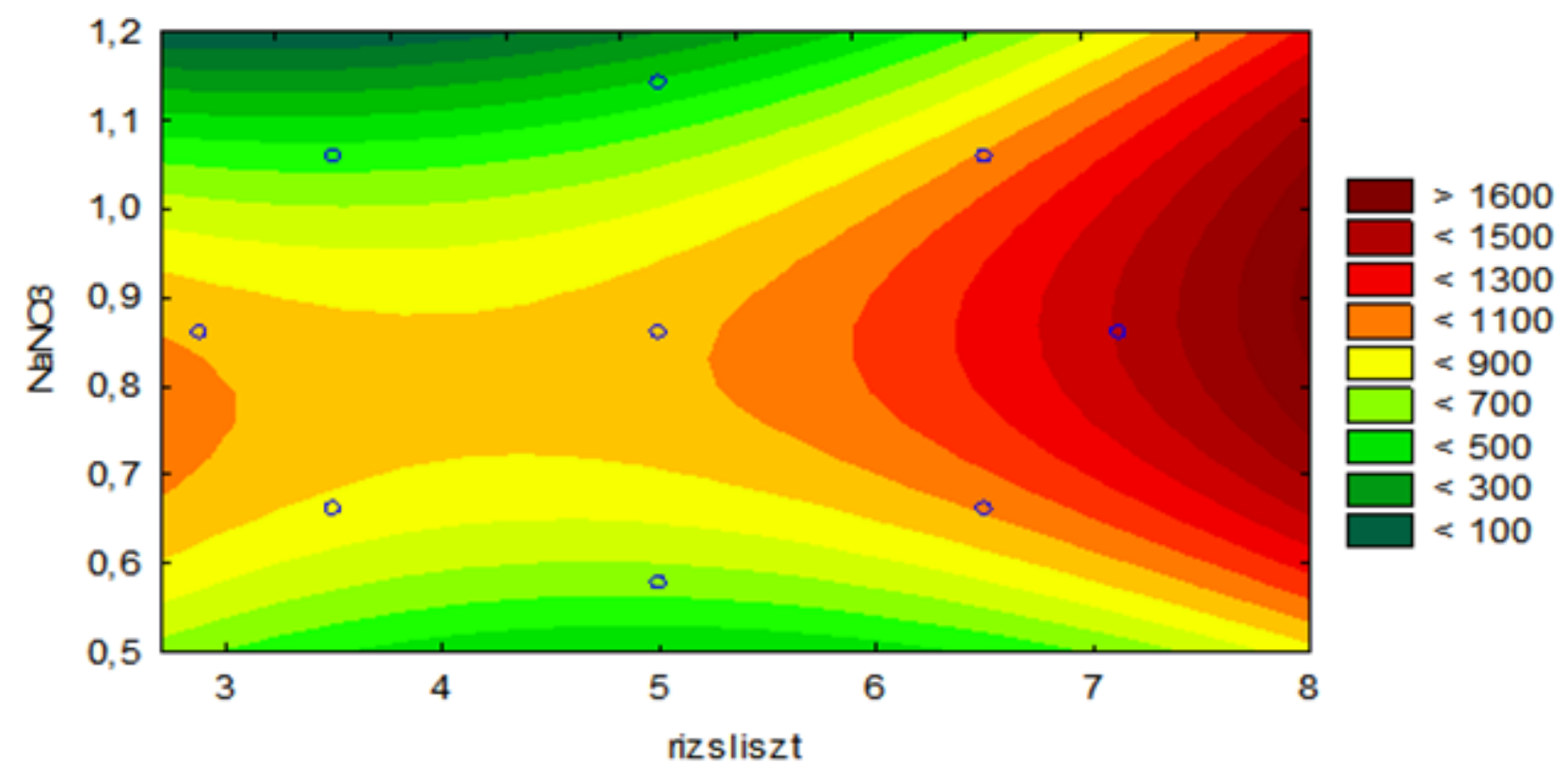

\section{0. ábra A rizsliszt és Na-nitrát koncentrációjának hatása az A. niger F00735 törzs eredetü fitáz enzim aktivitására $\left(28^{\circ} \mathrm{C}, 220 \mathrm{rpm}\right)$}

A statisztikai elemzés alapján (15. táblázat) mind a rizsliszt, mind a Na-nitrát egyedüli első- és másodfokú hatása, valamint együttes hatásuk is szignifikánsan befolyásolja a fitáz enzim termelés alakulását. Minden esetben a p-érték kisebb p<0,05-nél, azaz a két faktorról bebizonyosodott, hogy legalább 95\%-os biztonsági szinten enzimtermelést befolyásoló hatásuk van. 
15. táblázat Variancia analízis eredményei az A. niger F00735 törzs fitáz fermentációjához optimális rizsliszt és Na-nitrát meghatározásához

\begin{tabular}{|l|c|c|c|c|c|}
\hline \multicolumn{1}{|c|}{ Faktorok } & $\begin{array}{c}\text { Négyzetösszeg } \\
\text { (SS) }\end{array}$ & $\begin{array}{c}\text { Szabadsági } \\
\text { fok (df) }\end{array}$ & MS & $\mathbf{F}$ & p érték \\
\hline (1) rizsliszt (w/v\%) (L) & 187131 & 1 & 187131,2 & 349,1020 & 0,000335 \\
\hline rizsliszt (w/v\%) (Q) & 81243 & 1 & 81243,7 & 151,5621 & 0,001154 \\
\hline (2) Na-nitrát (w/v\%) (L) & 50828 & 1 & 50828,0 & 94,8221 & 0,002301 \\
\hline Na-nitrát (w/v\%) (Q) & 310917 & 1 & 310917,4 & 580,0309 & 0,000157 \\
\hline 1L by 2L & 26895 & 1 & 26895,0 & 50,1739 & 0,005787 \\
\hline Illeszkedési hiba & 936432 & 3 & 312144,1 & 582,3193 & 0,000120 \\
\hline Tiszta hiba & 1608 & 3 & 536 & & \\
\hline
\end{tabular}

Szubmerz fitáz fermentációk során különböző A. niger törzsekkel elért aktivitás értéket tekintve, eredményeim meghaladják a kukoricakeményítőn AHMAD és munkatársai (2000) által mért 1075 U/l, illetve GARGOVA és munkatársai (2006) által A. niger 307 törzs alkalmazásával kapott 324 nkat.ml ${ }^{-1}$ (190 U/l) értékeket. PAPAGIANNI és munkatársai (1999) kukoricakeményítő tartalmú tápközegen az enzimtermelés fokozását búzakorpával történő kiegészítéssel valósították meg, mellyel 20\%-os aktivitás növekedést, s 8000 U/l aktivitást értek el.

\subsubsection{Tápközeg pH-ja}

A fermentációs tápközeg kiindulási pH-jának hatását kívántam megvizsgálni a fitáz termelésre vonatkozóan. $\mathrm{pH}=3,5-5,5$ közötti tartományban Na-acetát puffert, $\mathrm{pH}=5,5-8,5$ között Tris-maleát/NaOH puffert alkalmaztam. Megállapítottam, hogy az Aspergillus niger F00735 törzs nem szaporodott $\mathrm{pH}=3,5-4$ értékre beállított tápközegekben, $\mathrm{s}$ minimális fitáz aktivitást mértem Naacetáttal beállított 4,5-5,5 közötti $\mathrm{pH}$ értékü fermentációs közegekben is. Tris-maleát/NaOH pufferrel készített $\mathrm{pH}=5,5$ és $\mathrm{pH}=6$ értékü tápközegekben mértem a maximális fitáz aktivitást, mely a kontrollal - azaz a desztillált vízzel készített rizslisztes tápközeggel - közel azonos értékeket mutatott. A pH további növelése az enzimaktivitás csökkenésével járt. A legjobbnak bizonyult $\mathrm{pH}=5,5$ és $\mathrm{pH}=6$ kiindulási értékekkel, valamint a kontroll mintával megismételtem a fermentációt. Eredményeimet a 31. ábrán mutatom be. A kezdetben beállított pH értékek - különösen a Trismaleát/NaOH pufferrel készített közegekben - már a fermentáció harmadik napján is jelentősen lecsökkentek, és azt követően folyamatosan $\mathrm{pH}=3$ értéken, illetve azalatt maradtak. A kontroll mintában, mely desztillált vízzel készült, a pH=3,3-3,4 értékü volt. 


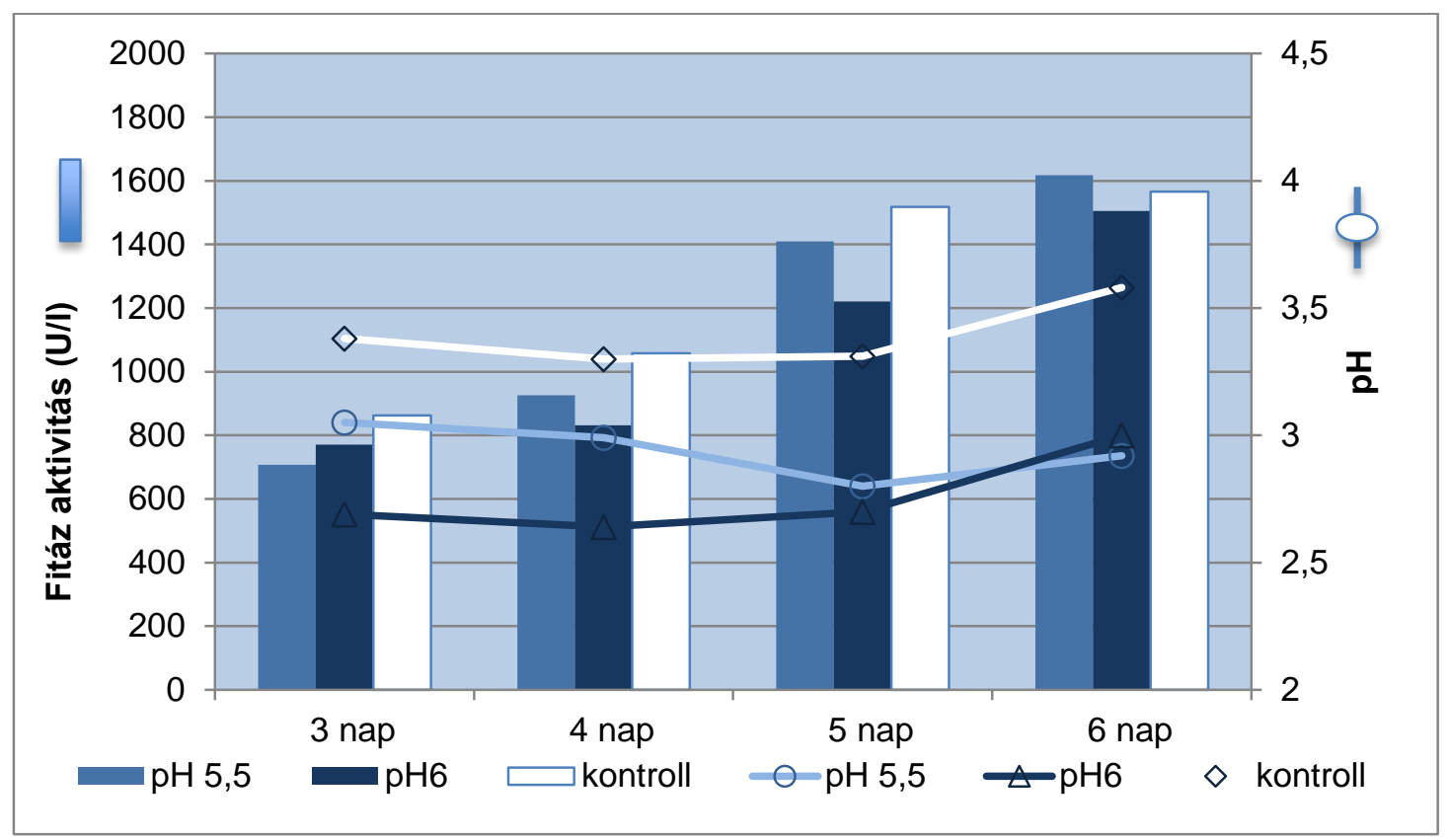

31. ábra. A fitáz aktivitás és a pH alakulása különböző kiindulási pH értékü tápközegekben

Összehasonlítva a pH állítás nélküli kontroll mintát, valamint a pufferrel készített tápközegeken mért fitáz aktivitásokat megállapítható, hogy pH szabályozás nélkül a 3., 4. és 5. napon is magasabb értékeket mértem. A fermentáció 6. napján, az eredmények közel azonos értéket mutattak a különböző kiindulási pH értékek esetén (1500-1600 U/1), ebből adódóan feleslegesnek ítéltem a kezdeti pH beállítását az Aspergillus niger F00735 törzs fitáz fermentációjához.

Több kutatócsoport is végzett hasonló kísérleteket Aspergillus eredetü fitáz fermentációk során, s a legjobb enzimtermelést abban az esetben kapták, ha a kiindulási tápközeg kémhatása enyhén savas tartományban volt. Aspergillus sp. 5990 fitáz termelése során, 4 napos fermentáció után a maximális enzim- és biomassza hozamot $\mathrm{pH}=6,0$ és 7,0 közötti kiindulási érték eredményezte (KIM et al. 1999). Aspergillus niger esetén pH=6,5, (VATS \& BANERJEE 2002), Aspergillus sp. 307 savas foszfatázánál pH=5 kiindulási érték (GARGOVA \& SARIYSKA 2003), s szintén savas tartományban - $\mathrm{pH}=5,5-5,8$ kiindulási értékkel - fermentáltak búzakorpával kiegészített kukoricakeményítő tartalmú tápközegen (PAPAGIANNI et al. 1999), a maximális enzimtermelés eléréséhez. Összességében megállapítható, hogy az Aspergillus eredetű fitáz fermentációjához enyhén savas, 5,5-6,5 kiindulási pH érték a legkedvezőbb. Mivel a pufferrel készített fermentációs tápközeggel sem érhető el jelentősebb aktivitás növekedés, a fermentációkat továbbra is desztillált vízzel készített tápközegekben valósítottam meg a kezdeti pH állítása nélkül. 


\subsubsection{Az optimális inokulum mennyiség és tápközeg térfogat meghatározása}

A következőkben az alkalmazott inokulum mennyiség hatását kívántam vizsgálni az Aspergillus niger F00735 törzs fitáz termelésére. Az enzimfermentációk megvalósítása során elönyös tulajdonság a pelletes morfológiai növekedés. Az adott törzs esetén is megfigyelhető e növekedési forma mind az inokulum, mind a fermentációs tápközegben 48 óra után (32. ábra).

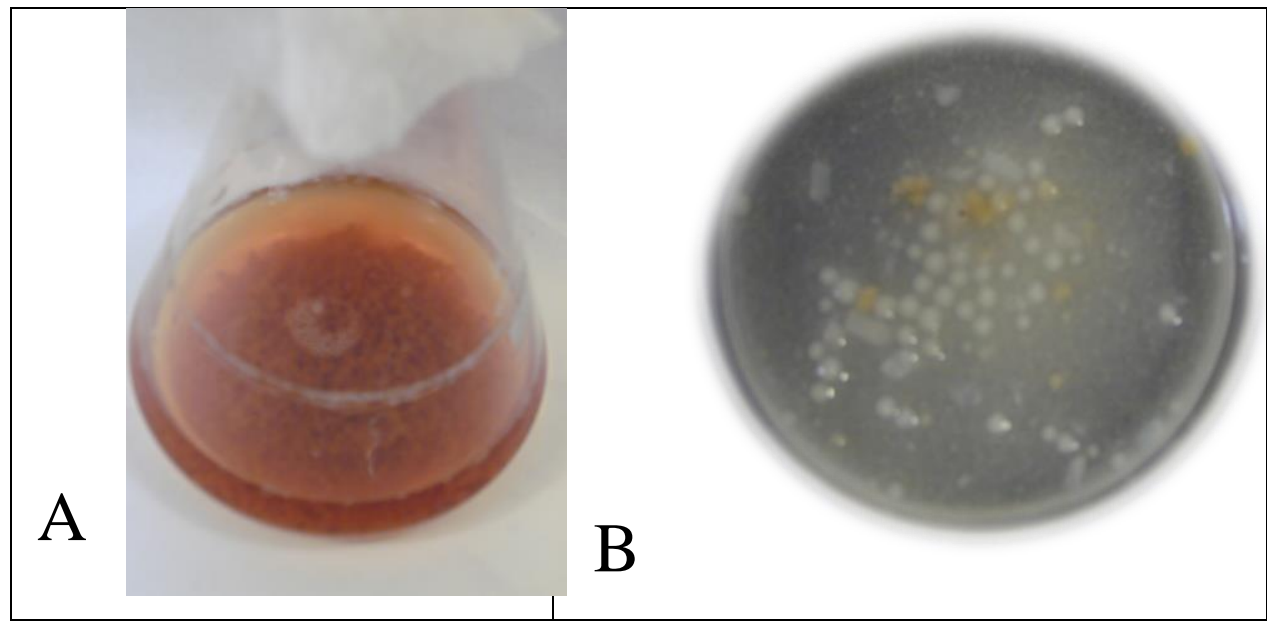

32. ábra $A$. niger F00735 törzs pelletes növekedése inokulum (A) és rizslisztes (B) tápközegben $\left(28^{\circ} \mathrm{C}, 48\right.$ óra)

Az inokulum tápközeg mennyiségi optimálása mellett vizsgáltam a lombikban lévő fermentációs tápközeg mennyiségének és a névleges térfogat arányának hatását is az enzimaktivitás alakulására. A kísérlethez kontrollként az eddigiekben alkalmazott 500 ml-es Erlenmeyer lombikokban $150 \mathrm{ml}$ töltöttség melletti 5 tf\% inokulum mennyiségekkel indított fermentáció enzimaktivitása szolgált. Vizsgáltam 1000 ml-es és 500 ml-es Erlenmeyer lombikban megvalósított fermentációk során az enzimaktivitás alakulását különböző töltöttség és inokulum mennyiség mellett (16. táblázat).

16. táblázat. A tápközeg és lombik térfogata, valamint arányuk az egyes kísérleti beállításoknál

\begin{tabular}{|c|c|c|}
\hline Tápközeg térfogat & Lombik térfogat & Arány \\
\hline $100 \mathrm{ml}$ & $500 \mathrm{ml}$ & 0,2 \\
\hline $150 \mathrm{ml}$ & $500 \mathrm{ml}$ & 0,3 \\
\hline $150 \mathrm{ml}$ & $1000 \mathrm{ml}$ & 0,15 \\
\hline $300 \mathrm{ml}$ & $1000 \mathrm{ml}$ & 0,3 \\
\hline
\end{tabular}

A különböző kísérleti beállítások során a 6. napon kapott ereményeim láthatók a 33. ábrán. 


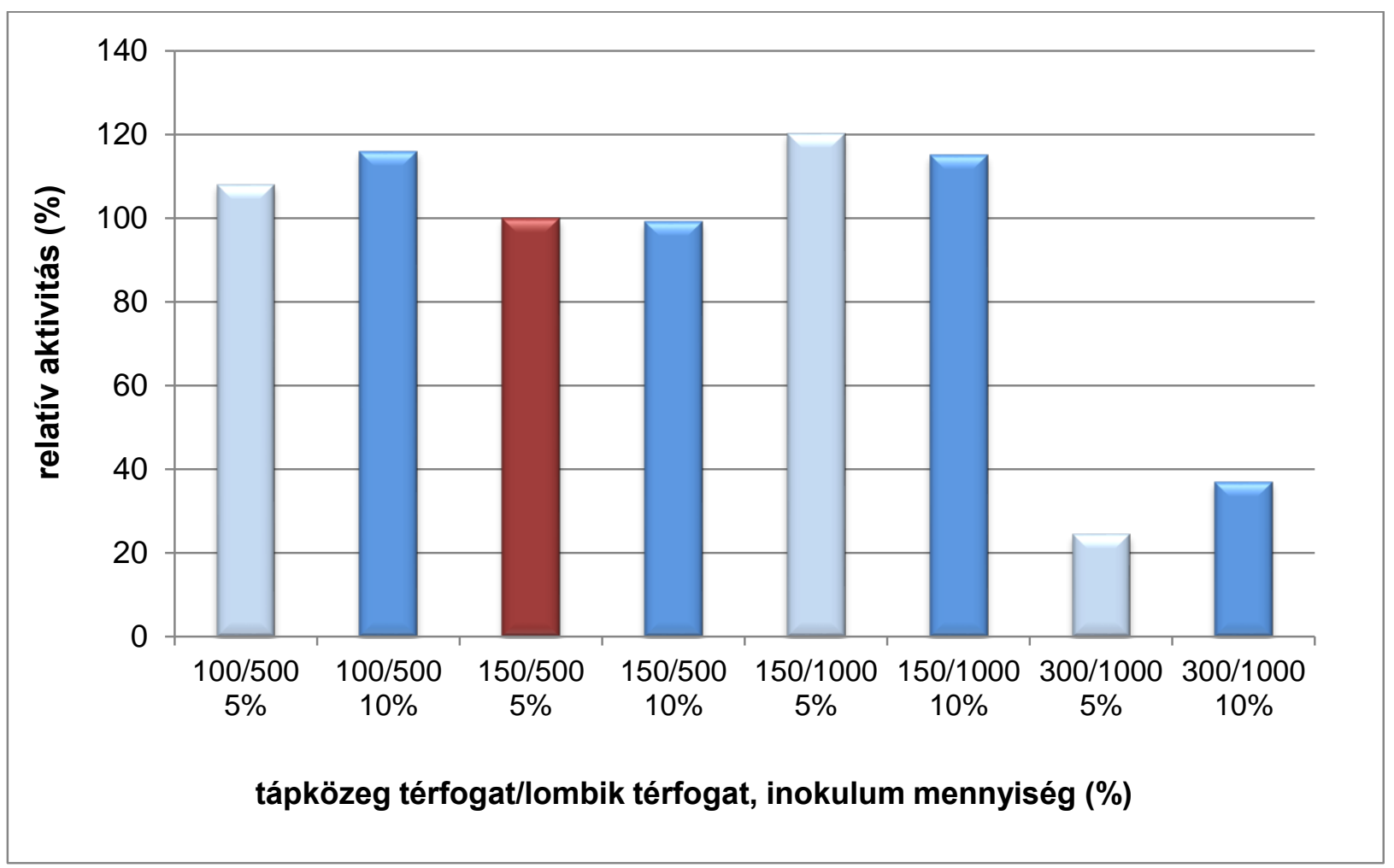

\section{3. ábra A különböző tápközeg térfogat/lombik térfogat és az inokulum mennyiség hatása a fitáz enzim alakulására $\left(28^{\circ} \mathrm{C}, 220 \mathrm{rpm}, 6\right.$. nap)}

Megállapítható, hogy a tápközeg és a lombik térfogat arányának növekedésével az enzim aktivitása csökken. Abban az esetben a leghatékonyabb a fitáz enzim termelése, ha $1000 \mathrm{ml}$ lombikban $150 \mathrm{ml}$ fermentációs közeget alkalmazunk, ebben az esetben nagyobb a levegőztetés mértéke, az oxigénátadási viszonyok javulnak. Az oxigénnek a levegőből a sejtben lévő enzimekig való eljutásáig vezető számos lépés közül szubmerz fermentáció esetén a gáz-folyadék határfelület ellenállása a legnagyobb, így ez a sebesség-meghatározó folyamat. Az intenzívebb folyadék mozgás növeli a gáz-folyadék felület nagyságát, emellett a folyadék mozgása miatt a határfelületen kialakuló oxigén koncentráció gradiens is nagy lesz, nő a hajtóerő.

Az inokulum mennyisége nincs jelentős hatással az enzim aktivitására. Bár $300 \mathrm{ml}$ töltöttség mellett $10 \mathrm{tf} \%$ inokulum mennyiséggel nagyobb aktivitás érhető el, mint $5 \mathrm{tf} \%$ inokulum alkalmazásával, de az így mérhető maximális aktivitás is csupán harmada a $150 \mathrm{ml}$ töltöttség mellett elért értékeknek. $100 \mathrm{ml}$ töltöttségnél is magasabb értéket kapunk a kontroll mintához képest, hisz ebben az esetben is növekszik a levegőztetés mértéke. Mindezek alapján megállapítható, hogy $1000 \mathrm{ml}$-es lombikban $150 \mathrm{ml}$ fermentációs tápközeget 5 tf\% inokulummal beoltva a fitáz aktivitás további 20\%-kal növelhető.

\subsubsection{Felületaktív anyagok hatása}

Az A. niger F00735 törzs fitáz enzim kiválasztásának fokozása végett, különböző felületaktív anyagok hatását vizsgáltam az optimált összetételü $(0,86 \%$ nátrium-nitrát és $7,1 \%$ 
rizsliszt) fermentációs tápközegben. Az egyes felületaktív anyagokat - Tween 20, Tween 40, Tween 60, Tween 65, Tween 80, Tween 85 és Triton X-100-0,1 (w/v)\%-os koncentrációban adtam a tápközeghez és mértem az enzimaktivitás alakulását a fermentáció során. A vizsgált felületaktív anyagok hatását a kontroll mintához hasonlítottam, mely felületaktív anyag kiegészítés nélkül készült, s a 7. napon kapott relatív aktivitás értékeket ábrázoltam (34. ábra).

A különböző felületaktív anyagok alkalmazásával a fitáz aktivitás növekedett a kontroll mintához képest, azonban a növekedés mértéke nem volt több 10-16 \%-nál. A $16 \%$-os növekedést Tween 20 alkalmazása esetén értem el. Triton X-100 is fokozta az enzim kiválasztását - a legkisebb mértékben ugyan - annak ellenére, hogy a szakirodalomban enzimaktivitás gátló hatásáról találhatók feljegyzések: EBUNE és munkatársai (1995) vizsgálatai alapján az Aspergillus ficuum fitáz enzime gátlódott a Triton X-100 használata során, s ugyanezt tapasztalták EL-BATAL és KAREM (2001) A. niger, valamint AL-ASHEH és DUVNJAK (1994) A. carbonarius fitáz enziménél. Ennek az eltérésnek oka lehet, hogy különböző törzsek esetében, eltérő koncentrációkban alkalmazták a felületaktív anyagokat.

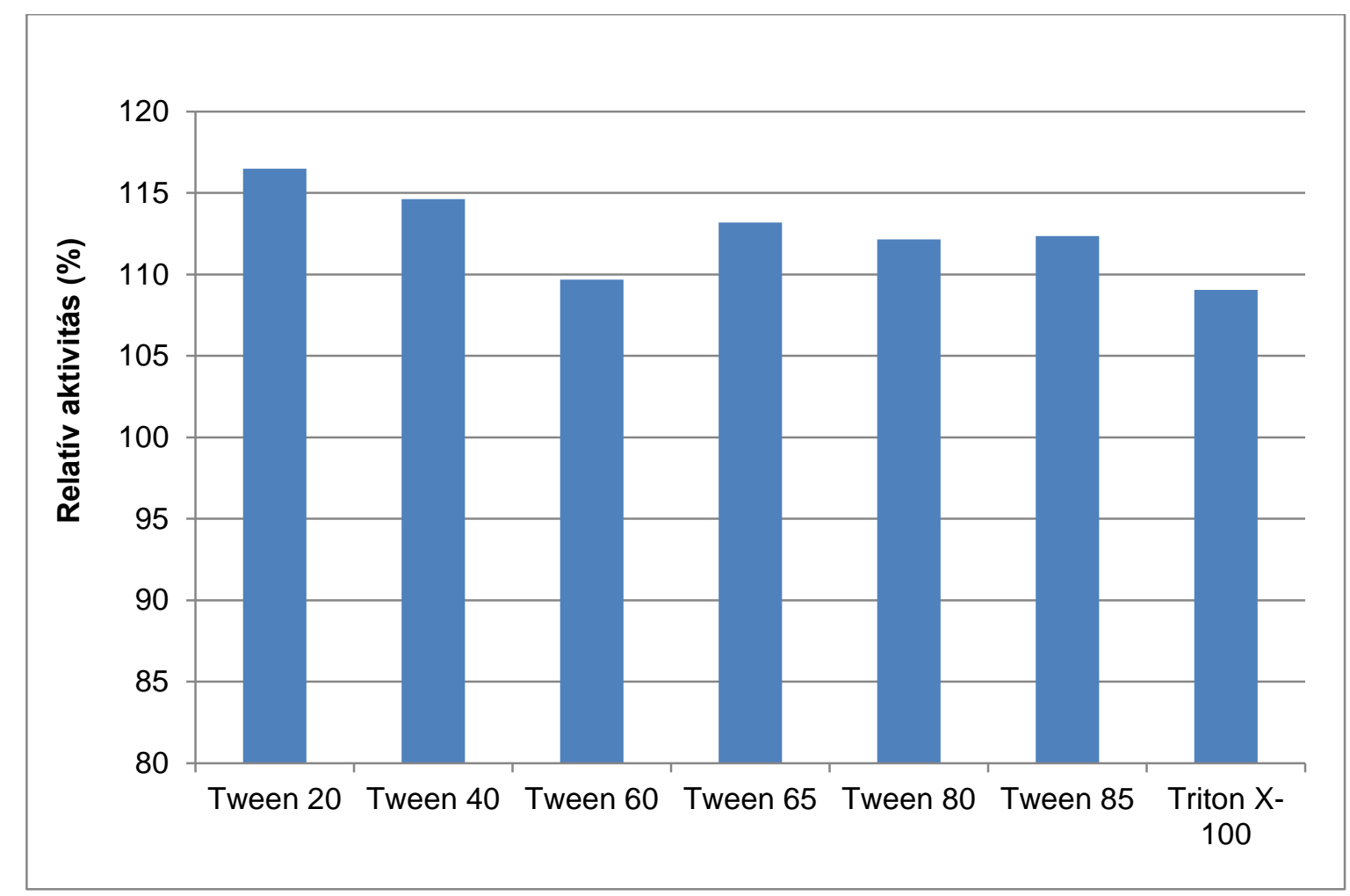

34. ábra A relatív aktivitás alakulása különböző felületaktív anyagok esetén a fermentáció

7. napján $(0,1$ (w/v)\% koncentráció, A. niger $\mathrm{F} 00735$ törzs $)$

A legjobbnak talált Tween 20 esetében különböző koncentrációk alkalmazásával - 0,05 $(\mathrm{w} / \mathrm{v}) \%, 0,1(\mathrm{w} / \mathrm{v}) \%, 0,2(\mathrm{w} / \mathrm{v}) \%, 0,3(\mathrm{w} / \mathrm{v}) \%$, és $0,4(\mathrm{w} / \mathrm{v}) \%$ - vizsgáltam a fitáz aktivitás alakulását. Az eredményeket a 35. ábrán mutatom be. 0,1\%-os koncentráció alkalmazása nem mutatott növekedést az enzimaktivitásban, sőt 0,2 \%-nál nagyobb koncentrációban alkalmazva a Tween 20 felületaktív anyagot, az enzim aktivitás csökkenése figyelhető meg. NEMEC és 
JERNEJC (2002) Aspergillus niger pektolitikus enzimének kiválasztását 0,1 (w/v)\% Tween 80 alkalmazásával 70 \%-kal növelték. LI és munkatársai (2001) kutatásai szerint az Acinetobacter radioresistens lipáz termelése fokozható $0,3(\mathrm{w} / \mathrm{v}) \%$ Tween 80 kiegészítéssel. Magasabb koncentráció alkalmazása ebben az esetben is gátló hatást okozott. Annak ellenére, hogy a felületaktív anyagok általában elősegítik az enzimek kiválasztását megfelelő koncentrációban alkalmazva, az Aspergillus niger F00735 törzs esetén e hatás nem jelentős, s a koncentráció növelésével gátló hatás figyelhető meg. Eredményeim alapján tehát e törzs fitáz fermentációja során felületaktív anyag kiegészítéssel nem növelhető az enzim szekréció.

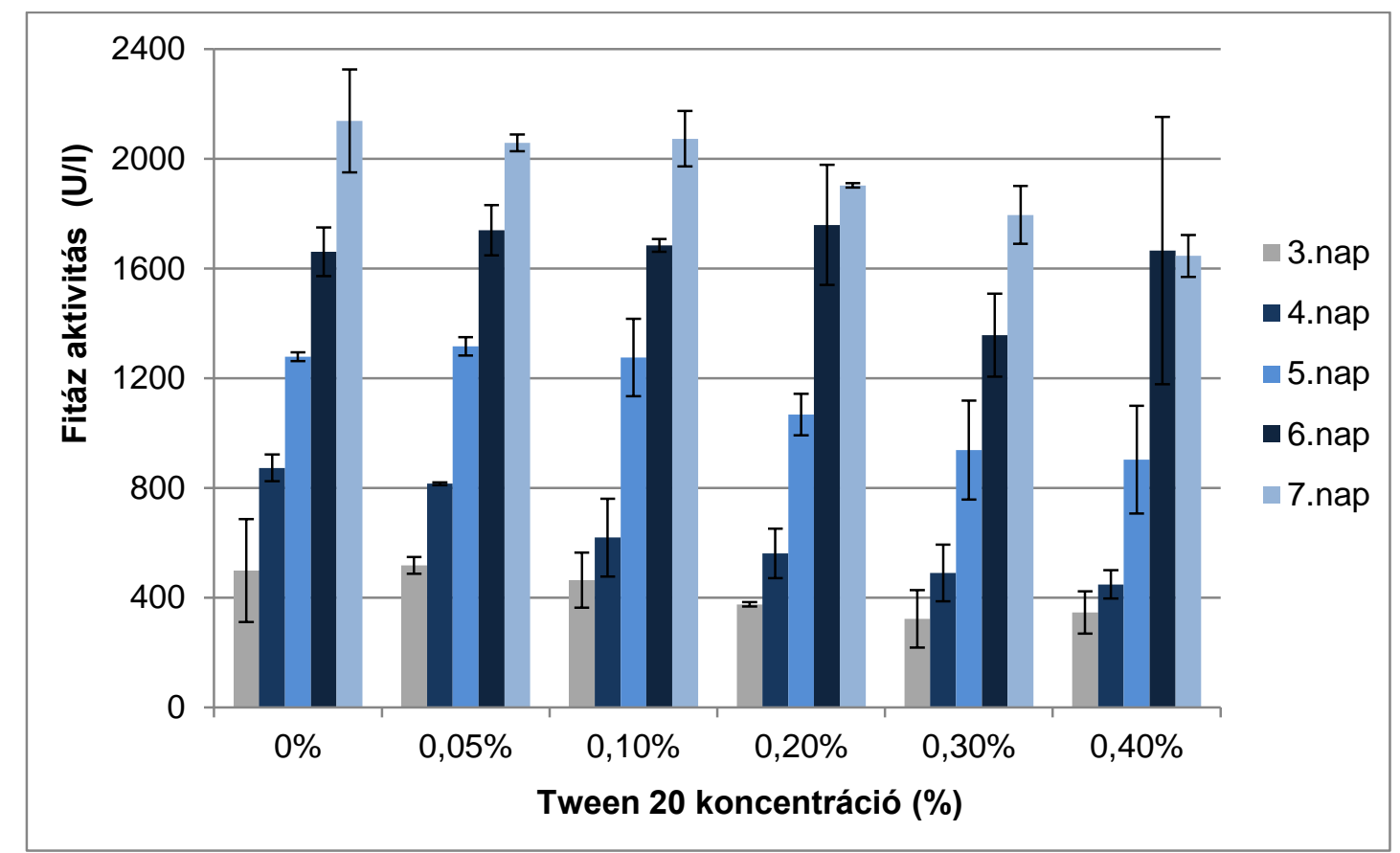

35. ábra Tween 20 különböző koncentrációinak hatása az Aspergillus niger fitáz enzimének kiválasztására

\subsection{Aspergillus niger eredetü fitáz enzim tisztítása}

Az enzim jellemzéséhez szükséges homogenitásig tisztított fehérje kinyeréséhez a hat napos fermentáció tenyészlevének szürletéből a fehérjék elválasztását frakcionált ammónium-szulfátos kicsapással valósítottam meg. Először 80 \%-os telítettséget állítottam be, s a csapadékkal a kísérő fehérjék egy részét elválasztottam. 


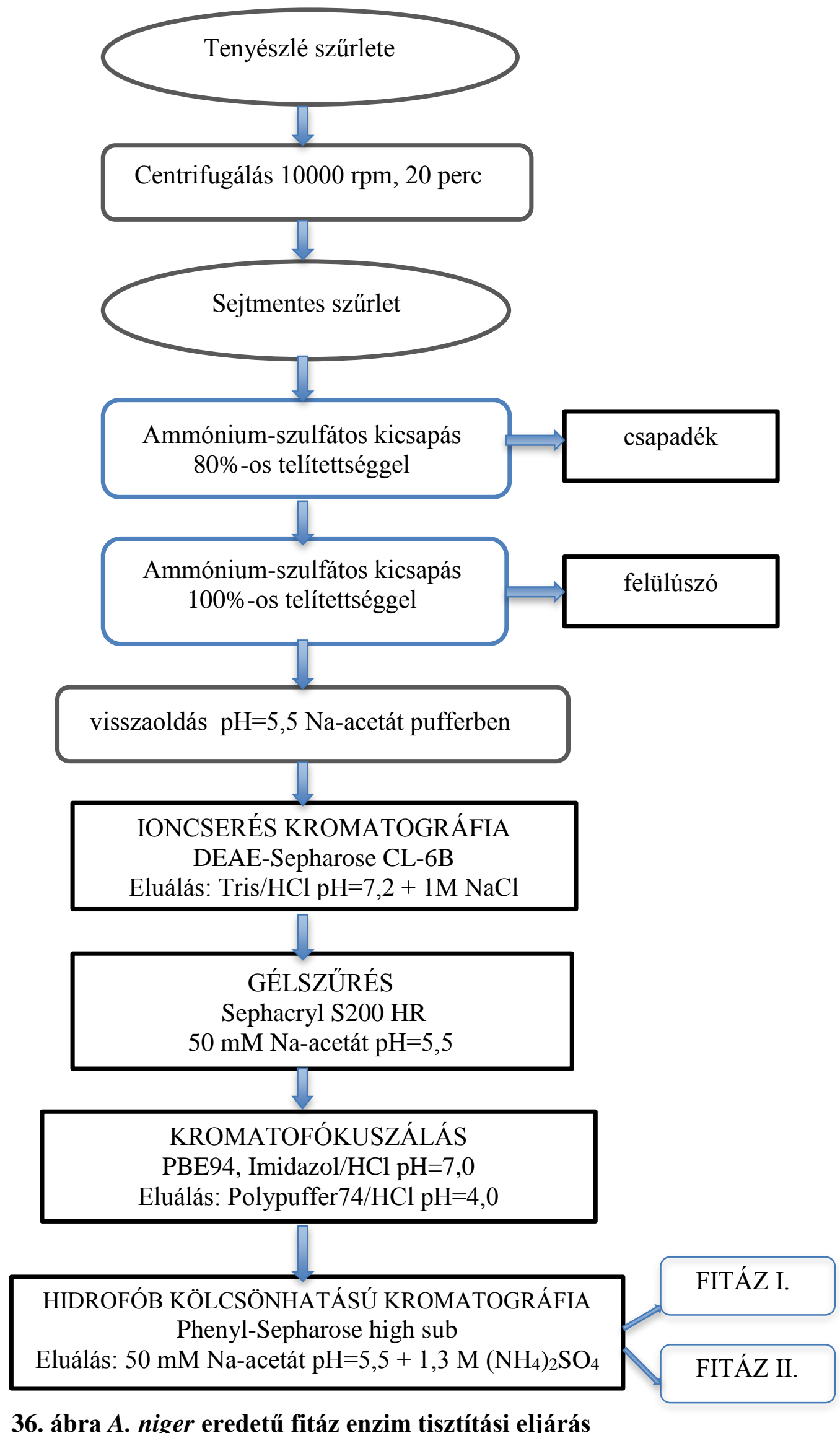

\section{6. ábra $A$. niger eredetű fitáz enzim tisztítási eljárás}


Ezt követően $100 \%$-os telítettségig adagolva az ammónium-szulfátot, egy éjszakás $4{ }^{\circ} \mathrm{C}$-on történő pihenő után, a többi fehérje is kicsapódott a fermentléből. A csapadékot centrifugálással összegyüjtöttem, pH=5,5 nátrium-acetát pufferban visszaoldottam, majd Amicon ultraszürö berendezéssel $10 \mathrm{kDa}$ vágási értékü membránon sómentesítettem és koncentráltam a mintát. A fehérje oldatból a fitáz enzim elválasztását FPLC berendezéshez csatlakoztatott kromatográfiás oszlopokon végeztem. A tisztítás folyamatát a 36. ábrán foglaltam össze.

Első lépésként DEAE Sepharose CL-6B töltetet tartalmazó oszlopot $(2,5 \mathrm{~cm}$ x $30 \mathrm{~cm})$ alkalmaztam, melyet TRIS/HCl pufferrel $(50 \mathrm{mM}, \mathrm{pH}=7,2)$ egyensúlyba hoztam. A megkötött fehérjéket $0 \mathrm{M}$ és $1 \mathrm{M}$ közötti $\mathrm{NaCl}$ sógradienssel eluáltam $10 \mathrm{ml}$-es frakciókat szedve. Az egyes kromatográfiás lépések között megmértem a frakciók fehérjetartalmát $280 \mathrm{~nm}$-en, valamint a fitáz enzim aktivitását, mely alapján a fitáz aktivitást mutató frakciókat egyesítettem és ultraszüréssel koncentráltam.

Az enzim további tisztítása gélszüréssel történt, Sephacryl S-200 töltetü $(1,5 \mathrm{~cm} \mathrm{x} 100 \mathrm{~cm})$ gyantát alkalmazva. $50 \mathrm{mM}$ Na-acetát pufferrel $(\mathrm{pH}=5,5) 0,4 \mathrm{ml} /$ perc áramlási sebesség mellett eluáltam a megkötött fehérjéket, 7 ml-es frakciókat szedve. Az aktivitást mutató frakciókat ultraszürés után a következő tisztítási lépésre vittem. A kromatofókuszáláshoz PBE94 gyantát alkalmaztam, s az oszlopot $(1 \mathrm{~cm}$ x $30 \mathrm{~cm})$ imidazol/HCl pufferrel $(\mathrm{pH}=7,0)$ egyensúlyba hoztam. A minta felvitele után, a megkötött fehérjék lemosása polipuffer $74 / \mathrm{HCl}$ puffer $(\mathrm{pH}=4,0)$ segítségével előállított $\mathrm{pH}$ gradienssel történt $1 \mathrm{ml} /$ perc áramlási sebességgel, $3 \mathrm{ml}$-es frakciókat szedve. Az aktív frakciók összegyüjtése és ultraszürése után hidrofób kölcsönhatáson alapuló kromatográfiát alkalmaztam az enzim további tisztításához. A Phenyl Sepharose high-sub gyantát tartalmazó oszlopot $50 \mathrm{mM} \mathrm{Na-acetát} \mathrm{puffer}\left(\mathrm{pH}=5,5,1,3 \mathrm{M}\left(\mathrm{NH}_{4}\right)_{2} \mathrm{SO}_{4}\right)$ segítségével telítettem, majd injektáltam a mintát. A megkötött fehérjéket 1,3 $\mathrm{M}-0 \mathrm{M}$ ammónium sógradienssel mostam le. E tisztítási lépés kromatogramját a 37. ábrán mutatom be.

A kromatogramon jól látható a tisztítási eljárás végeredményeként kapott két elkülönült fehérje csúcs, melyek fitáz aktivitást mutattak. Külön-külön gyüjtöttem össze a frakciókat, s a két csúcsot fitáz I.-nek, valamint fitáz II.-nek neveztem. Amicon ultraszűrő egységgel történő dializálás és koncentrálás után, megmértem az enzimaktivitásokat: a fitáz I. 9891 U/1, a fitáz II. pedig 3026 U/1 aktivitást mutatott. A kinyert enzimek homogenitását és molekula tömegét SDS-poliakrilamidgélelektroforézissel határoztam meg (LAEMMLI, 1970). A 38. ábrán látható elektroforetogramon egy-egy fehérjesáv jelzi a homogén fitáz enzimeket. Mivel mindkét fehérje fitáz aktivitással rendelkezik, és a molekulatömegük különböző, feltételezhető, hogy két fajta fitáz enzimről van szó. 


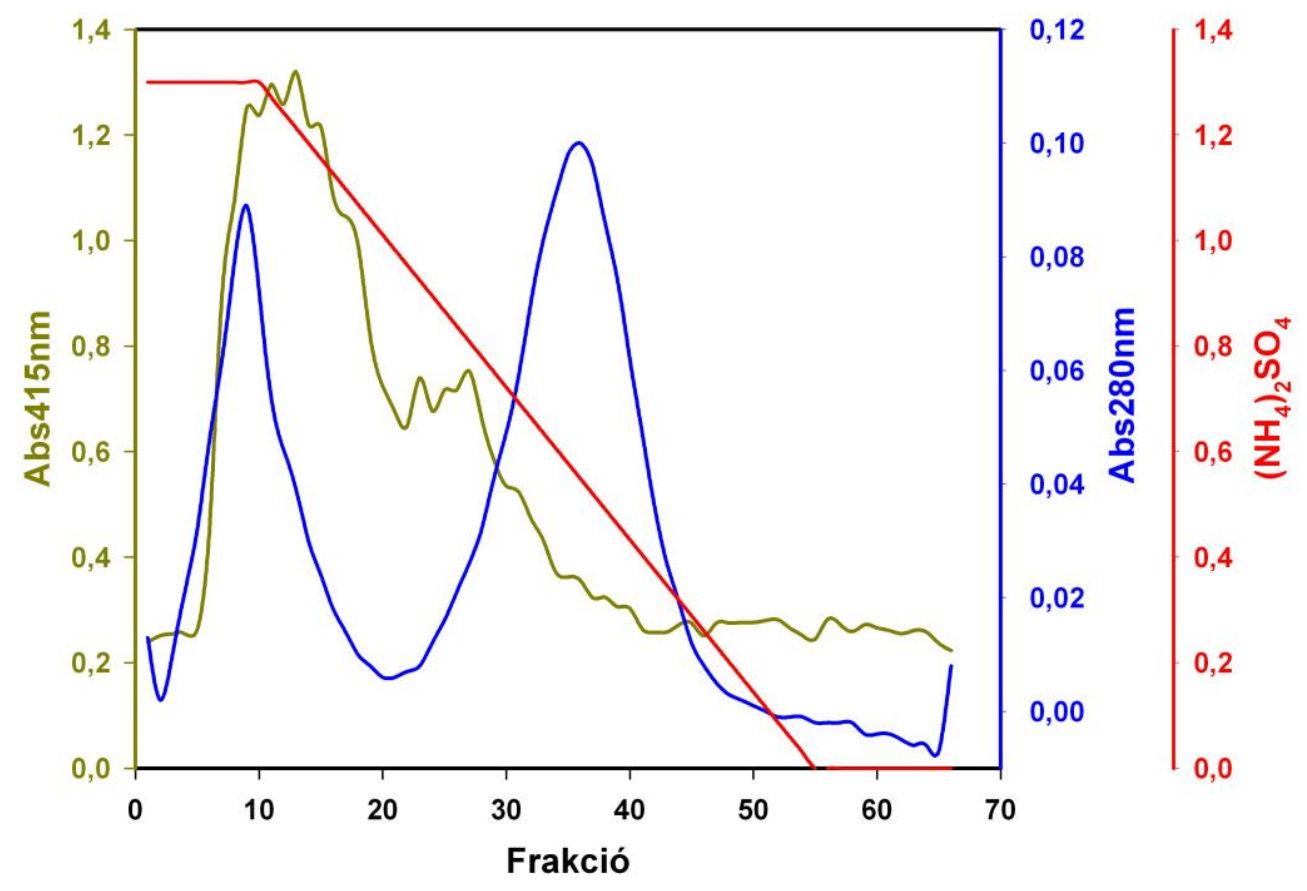

37. ábra Hidrofób kölcsönhatáson alapuló kromatográfiás tisztítási lépés kromatogramja

(Phenyl Sepharose high-sub) (Abs $415 \mathrm{~nm}$ - fitáz aktivitás, Abs $280 \mathrm{~nm}$ fehérje tartalom)

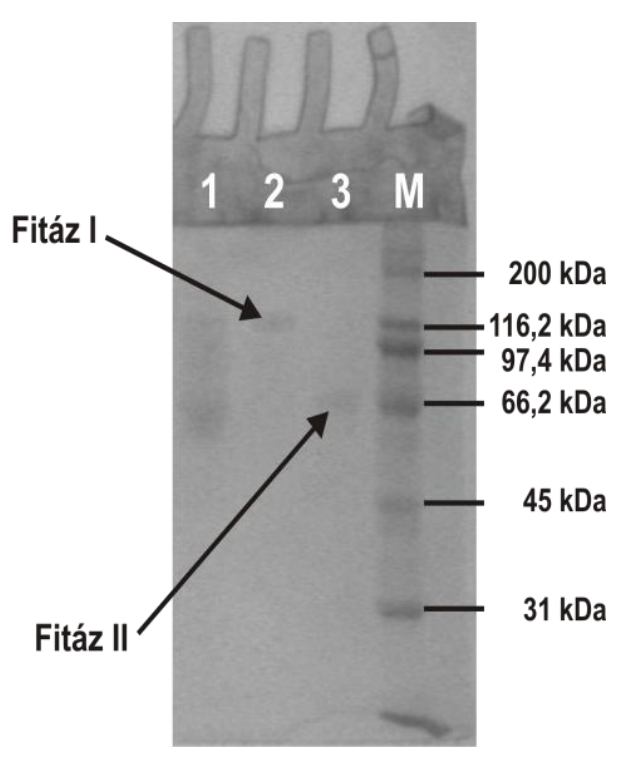

38. ábra. Az A. niger F00735 törzs eredetű fitáz enzimek elektroforetogramja

1: fehérjék kromatofókuszálás után, 2: Fitáz I, 3: Fitáz II, M: molekulamarkerek: 200 kDa miozin; 116,2 kDa $\beta$-galaktozidáz; 97,4 kDa foszforiláz; 66,2 kDa marha szérum albumin; 45 kDa ovalbumin; 31 kDa anhidráz

A tisztítási folyamat eredményeként kapott fehérjéket 15,3\%-ban sikerült kinyerni, 25,7szeres tisztulást elérve. A tisztítási folyamat anyagmérlegét a 17. táblázatban foglaltam össze. 
17. táblázat: A. niger F00735 törzs fitáz enzimeinek tisztítási lépései és a folyamat jellemzői

\begin{tabular}{|c|c|c|c|c|c|}
\hline LÉPÉSEK & $\begin{array}{c}\text { Össz. } \\
\text { aktivitás } \\
\text { (U) }\end{array}$ & $\begin{array}{l}\text { Össz. } \\
\text { fehérje } \\
(\mathrm{mg})\end{array}$ & $\begin{array}{c}\text { Specifikus } \\
\text { aktivitás } \\
\text { (U/mg) }\end{array}$ & $\begin{array}{c}\text { Kitermelés } \\
(\%)\end{array}$ & Tisztulás \\
\hline FERMENTLÉ & 414 & 88,0 & 4,7 & 100,0 & 1,0 \\
\hline KICSAPÁS UTÁN & 336 & 10,8 & 31,2 & 81,2 & 6,6 \\
\hline $\begin{array}{l}\text { IONCSERÉLŐ } \\
\text { KROMATOGRÁFIA }\end{array}$ & 292 & 5,7 & 51,3 & 70,6 & 10,9 \\
\hline GÉLSZÜRÉS & 62 & 1,6 & 38,5 & 15,0 & 8,2 \\
\hline KROMATOFÓKUSZÁLÁS & 99 & 1,4 & 68,7 & 23,9 & 14,6 \\
\hline $\begin{array}{l}\text { HIDROFÓB KÖLCSÖNHATÁSÚ } \\
\text { KROMATOGRÁFIA }\end{array}$ & 63 & 1,3 & & 15,3 & \\
\hline Fitáz I. & 43 & 0,4 & 98,9 & 10,5 & 21,0 \\
\hline Fitáz II. & 20 & 0,9 & 22,2 & 4,8 & 4,7 \\
\hline
\end{tabular}

Több kutatócsoport foglalkozott Aspergillus törzsek extracelluláris fitáz enzimeinek tisztításával (18. táblázat). A. niger 307 törzs fitáz enziménél csupán két kromatográfiás oszlopot Sephadex G-100 és DEAE-Sepharose CL 6B - alkalmazva homogén fitáz enzimet kaptak, s 30szoros tisztulást és nagy specifikus aktivitást (5662 nkat/mg) értek el, azonban a kitermelés csupán $3,81 \%$ (SARIYSKA et al. 2005).

18. táblázat Aspergillus törzsek tisztítási hatékonysága

\begin{tabular}{|l|c|c|l||}
\hline \multicolumn{1}{|c|}{ Mikroorganizmus } & Kitermelési \% & Tisztulási faktor & \multicolumn{1}{|c|}{ Hivatkozás } \\
\hline A. niger 307 & $3,81 \%$ & 30 & SARIYSKA et al. (2005) \\
\hline A. niger 11T53A9 & $20,3 \%$ & 51 & GREINER et al. (2009) \\
\hline A. oryzae & $18 \%$ & 38,9 & SHIMIZU (1993) \\
\hline A. ficuum & $58 \%$ & 22 & ULLAH és GIBSON (1987) \\
\hline A. niger SK 57 & $2,5 \%$ & 11 & NAGASHIMA et al. (1999) \\
\hline $\begin{array}{l}\text { A. niger F00735 } \\
\text { (fitáz I és fitáz II) }\end{array}$ & $15,3 \%$ & 25,7 & BUJNA et al. 2007 \\
\hline
\end{tabular}

A. niger 11T53A9 törzsnél ioncserés kromatográfia és gélszürés alkalmazásával 4 lépésben értek el 51-szeres tisztulást 20,3\% kinyeréssel (GREINER et al. 2009). SHIMIZU (1993) A. oryzae fitáz enzimének tisztítását 7 lépéssel valósította meg, s 38,9-szeres tisztulás mellett $18 \%$-os volt a kinyerés. ULLAH és GIBSON (1987) A. ficuum fitáz enzimét három kromatográfiás lépésben választotta el a többi fehérjétől, 22-szeres tisztulást érve el, $58 \%$ kinyerés mellett. Szilárd szubsztrátumú fermentációval előállított A. niger SK 57 eredetű fitáz enzim tisztítása során 11-szeres tisztulást értek el 2,5\% kinyeréssel (NAGASHIMA et al. 1999). A tisztítás során alkalmazott módszerek közül leggyakrabban az ioncserés kromatográfia és a gélszürés fordult elő. 
Az általam elért eredmények nem állnak távol e kutatócsoportok Aspergillus tisztítása során kapott értékeitől.

\subsection{Aspergillus niger eredetű fitáz enzim jellemzése}

\subsubsection{Molekulatömeg}

A molekulatömeg meghatározást SDS-poliakrilamid gélelektroforézissel valósítottam meg. A fitáz I. molekulatömege 117-120 kDa körüli, míg a fitáz II. molekulatömege 65-67 kDa volt (38. ábra). CASEY és WALSH (2003, 2004) Aspergillus niger ATCC 9142 törzs tisztítása során 84 kDa molekulatömegü, valamint Rhizopus oligosporus ATCC 22959 törzs alkalmazásával 120 kDa molekulatömegü fitáz enzimet nyertek ki. További Aspergillus eredetü tisztított fitáz enzimek molekulatömege: A. fumigatus $60 \mathrm{kDa}$ (PASAMONTES et al. 1997), A. niger 11T53A9 törzs 85 kDa (GREINER et al. 2009), A. niger 92 törzs 100 kDa (DVORÁKOVÁ et al. 1997), A. ficuum NRRL 3135 törzs 85-100 kDa (ULLAH \& GIBSON 1987) SDS-PAGE alkalmazásával. SONI és KHIRE (2007) A. niger NCIM 563 két fitáz enzimét tisztították, melyek molekulatömegét gélszüréssel határozták meg, ezek mérete 304 illetve $183 \mathrm{kDa}$, mely utalhat arra, hogy több monomerből áll. Az általam tisztított fitáz II. molekulatömege megegyezik a Natuphos néven forgalmazott $A$. niger eredetü fitáz SDS-PAGE módszerrel meghatározott molekulatömegével, mely $66,36 \pm 2,44 \mathrm{kDa}$ (WYSS et al. 1999b). A 117-120 kDa érték valamivel nagyobb, mint a fonalas gombáknál tapasztalt molekulatömeg. A fitáz enzimek általában monomer fehérjék. Kivételt képez az A. terreus eredetű fitáz enzim, mely szerkezeténél 6 alegységet állapítottak meg. Ez molekulatömegében is megnyilvánul (214 kDa) (YAMAMOTO et al. 1972). VATS és BANERJEE (2005) az általuk izolált hipertermelő A. niger van Tieghem törzs nagy molekulatömegéből (353 kDa) következtettek a natív fitáz oligomer szerkezetére, melyben egy monomer 66 kDa molekulatömegü lehet.

Az izoelektromos pontot kromatofókuszálással 4,2-4,7 értéknek becsültem. Ez teljesen megegyezik a gomba eredetű fitázokra jellemző izoelektromos pont értékekkel, melyek általában 4,0 - 5,5 közöttiek, de ettől eltérő pl. VATS és BANERJEE (2005) által tisztított $A$. niger eredetü fitáz enzim, mely pI-je 3,8, vagy az A. fumigatus fitáza, melynek izoelektromos pontja 7,28 (WYSS et al. 1999).

\subsection{2 pH optimum}

A tisztított enzimkészítmény $\mathrm{pH}$ függését $\mathrm{pH}=1,5-9$ közötti tartományban vizsgáltam $60^{\circ} \mathrm{C}$-on $\mathrm{Na}$-citrát/HCl, Na-acetát és Tris-maleát $/ \mathrm{NaOH}$ pufferek jelenlétében. Az aktivitásmérés eredményeként megállapítható, hogy a pH optimum a fitáz I. és II esetén is savas tartományban található. Eredményeim a 39. ábrán láthatók. A fitáz I. esetén az Aspergillus fajokra gyakran 
jellemző $\mathrm{pH}=5,0$, míg fitáz II.-nél $\mathrm{pH}=3,5$ értéknél mérhető a maximális aktivitás. A pufferek összetétele is befolyásolta az enzimek aktivitását, a legmagasabb aktivitás értékeket Na-acetát puffer alkalmazásával értem el, azonos $\mathrm{pH}$-n alkalmazott Na-citrát/HCl puffer esetén az aktivitás 20-50\%-a a Na-acetáton mértéhez képest. A. terreus pH optimuma 5,0-5,5 és A. niger esetén is mértek eredményeimhez hasonlóan savas tartományban két $\mathrm{pH}$ optimumot, $\mathrm{pH}=2,2$ és $\mathrm{pH}=5,0-5,5$ értékeken (ULLAH \& GIBSON 1987, WYSS et al. 1999a). A két pH optimummal rendelkező enzimek ipari alkalmazása igen kedvező lehet.
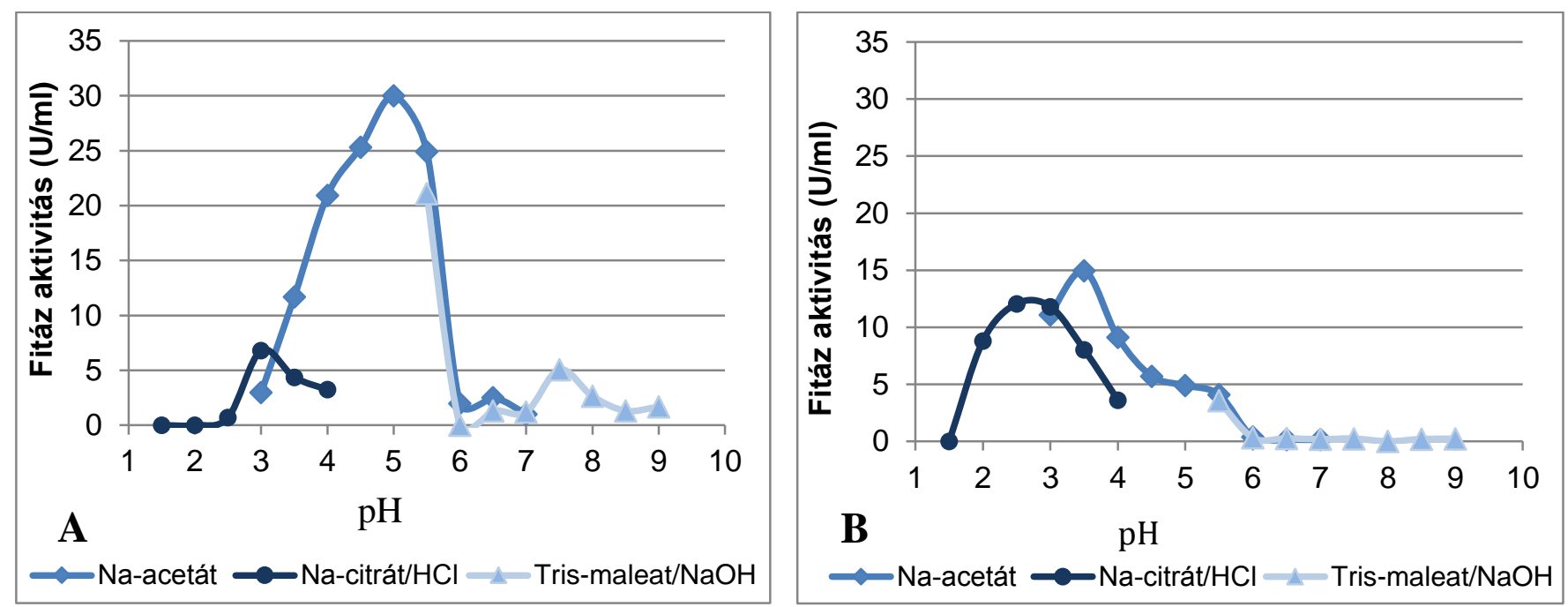

39. ábra A két Aspergillus niger F00735 törzs eredetü fitáz enzim, fitáz I (A) és fitáz II. (B) pH optimuma

\subsubsection{Hőmérséklet függés}

Mindkét fitáz enzim esetén a hőmérséklet aktivitásra gyakorolt hatását $30^{\circ} \mathrm{C}$-tól $75^{\circ} \mathrm{C}$-ig terjedő tartományban vizsgáltam enzimaktivitás mérésen keresztül. Megállapítható, hogy mindkét enzim $60^{\circ} \mathrm{C}$-on mutatta a legnagyobb aktivitást (40. ábra). A hőmérséklet további emelésével az enzimaktivitás jelentősen csökkent: $65^{\circ} \mathrm{C}$-on fitáz I. esetén 38\%-ra, fitáz II. esetén $27 \%$-ra, míg $75^{\circ} \mathrm{C}$-on az aktivitás mérés 10 perces reakció ideje alatt $25 \%$ illetve $22 \%$-ra csökkent. Megfigyelhető továbbá, hogy $75^{\circ} \mathrm{C}$-on hasonló mértékủ az enzimaktivitás, mint $37^{\circ} \mathrm{C}$-on. 


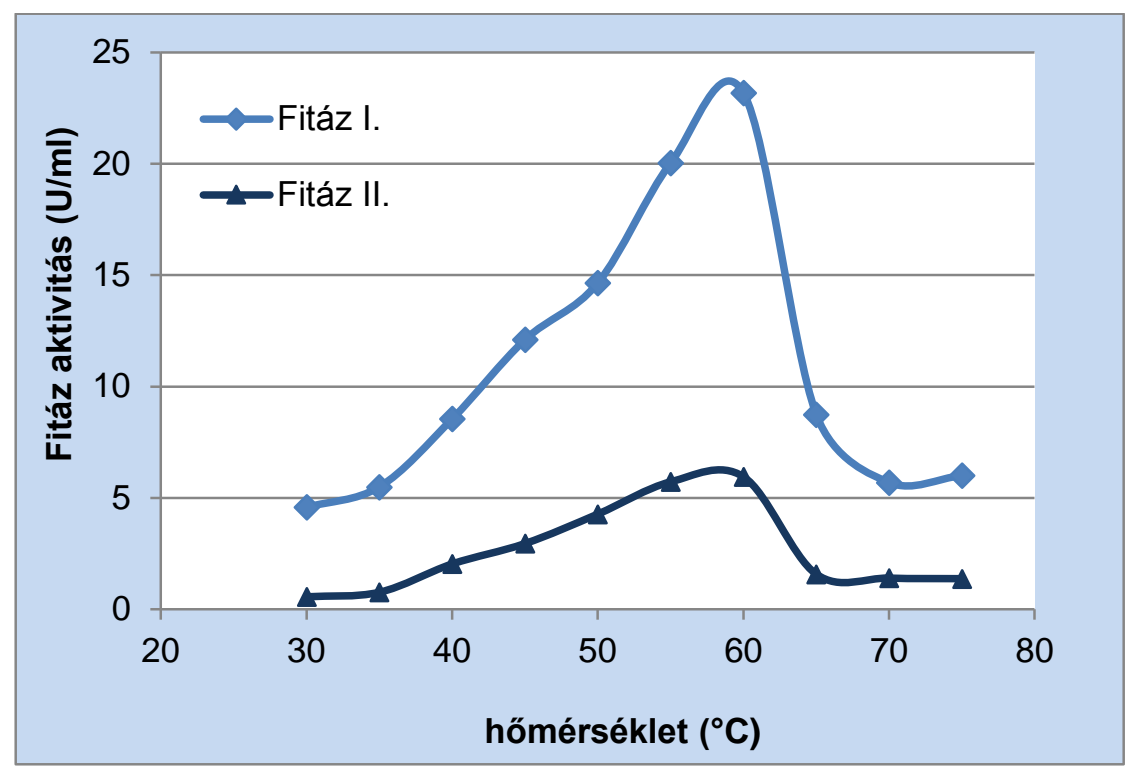

40. ábra Aspergillus niger F00735 fitáz enzimeinek hőmérséklet függése

A kapott eredmények megfelelnek a szakirodalomban fellelhetö Aspergillus niger eredetü fitáz enzimre vonatkozó optimális hőmérséklet értékeknek: A. niger SK-57 törzsnél $50^{\circ} \mathrm{C}$ (NAGASHIMA et al. 1999), A. niger 92 törzsnél 55C (DVORÁKOVÁ et al. 1997), A. niger NRRL 3135 törzsnél $58^{\circ} \mathrm{C}$ (ULLAH \& GIBSON 1987), míg A. niger ATCC 9142 törzs esetén $65^{\circ} \mathrm{C}$ (CASEY \& WALSH 2003) értékeket állapítottak meg az egyes kutatócsoportok.

\subsubsection{Stabilitás}

A fitáz enzimkészítmény stabilitását az enzimek hőmérséklet optimumához közeli $\left(50{ }^{\circ} \mathrm{C}\right.$, $55^{\circ} \mathrm{C}$ és $60^{\circ} \mathrm{C}$ ) hőmérsékleteken mértem. A mért adatok alapján a különböző hőmérsékleteken a felezési idők között jelentős különbségeket tapasztaltam a két enzimnél, és megállapítottam, hogy a fitáz II. bizonyult stabilabbnak (19. táblázat). A legnagyobb eltérés $60^{\circ} \mathrm{C}$-on volt, ahol a fitáz I. 1,5 óráig, míg a fitáz II. 54 óráig megőrizte aktivitásának $50 \%$-át. $55{ }^{\circ} \mathrm{C}$-on a fitáz I. esetén 2 nap, a fitáz II. esetén 5 nap az enzimek felezési ideje.

19. táblázat Aspergillus niger F00735 törzs tisztított fitáz enzimeinek felezési ideje különböző hőmérsékleteken

\begin{tabular}{|c|c|c|}
\hline \multirow{2}{*}{ Hőmérséklet } & \multicolumn{2}{|c|}{ Felezési idő (óra) } \\
\cline { 2 - 3 } & Fitáz I. & Fitáz II. \\
\hline $\mathbf{6 0}{ }^{\circ} \mathbf{C}$ & 1,5 & 54 \\
\hline $\mathbf{5 5}^{\circ} \mathbf{C}$ & 48 & 120 \\
\hline $\mathbf{5 0}^{\circ} \mathbf{C}$ & 720 & 1440 \\
\hline
\end{tabular}

$50{ }^{\circ} \mathrm{C}$-os hőmérsékleten a stabilabbnak bizonyuló fitáz II. aktivitásának $50 \%$-át, míg a fitáz I $25 \%$ át megőrizte aktivitásának, 2 hónap elteltével. Az általam tisztított fitáz enzimek stabilitásai 
messzemenően meghaladják többek közt DVORÁKOVÁ és munkatársai (1997) eredményeit, hiszen az általuk vizsgált $A$. niger fitázának felezési ideje $40^{\circ} \mathrm{C}$-on 2 óra.

\subsubsection{Fémionok hatása az enzimaktivitásra}

A fémionoknak az enzim müködésére kifejtett hatásának vizsgálatát enzimaktivitás méréssel határoztam meg, $5 \mathrm{mM}$ koncentrációban alkalmazva az egyes ionokat. A kontroll minta nem tartalmazta egyik iont sem, ezt vettem $100 \%$-nak. A két fitáz enzim aktivitására az egyes ionok jelenléte eltérő hatással volt (41. ábra). A fitáz I. enzim elsődleges aktivátorai a $\mathrm{Mg}^{2+}$ és $\mathrm{Mn}^{2+}$ ionok voltak, melyek esetében az aktivitás 2,7-szeresére növekedett. $\mathrm{A} \mathrm{Ca}^{2+}$ és $\mathrm{Co}^{2+}$ ionok alkalmazása esetén a relatív aktivitás szintén jelentős, 2,4-szeres aktivitás növekedést tapasztaltam ez ionok jelenlétében. A vizsgált egyvegyértékü ionok közül a $\mathrm{Na}^{+}$és $\mathrm{K}^{+}$alkalmazása mellett a relatív aktivitás 200\%-os. Érdekes megjegyezni, hogy a fitáz I. enzim aktivitását serkentő ionok közül a kétvegyértéküek magasabb aktivitást eredményeznek, mint az egyvegyértéküek.

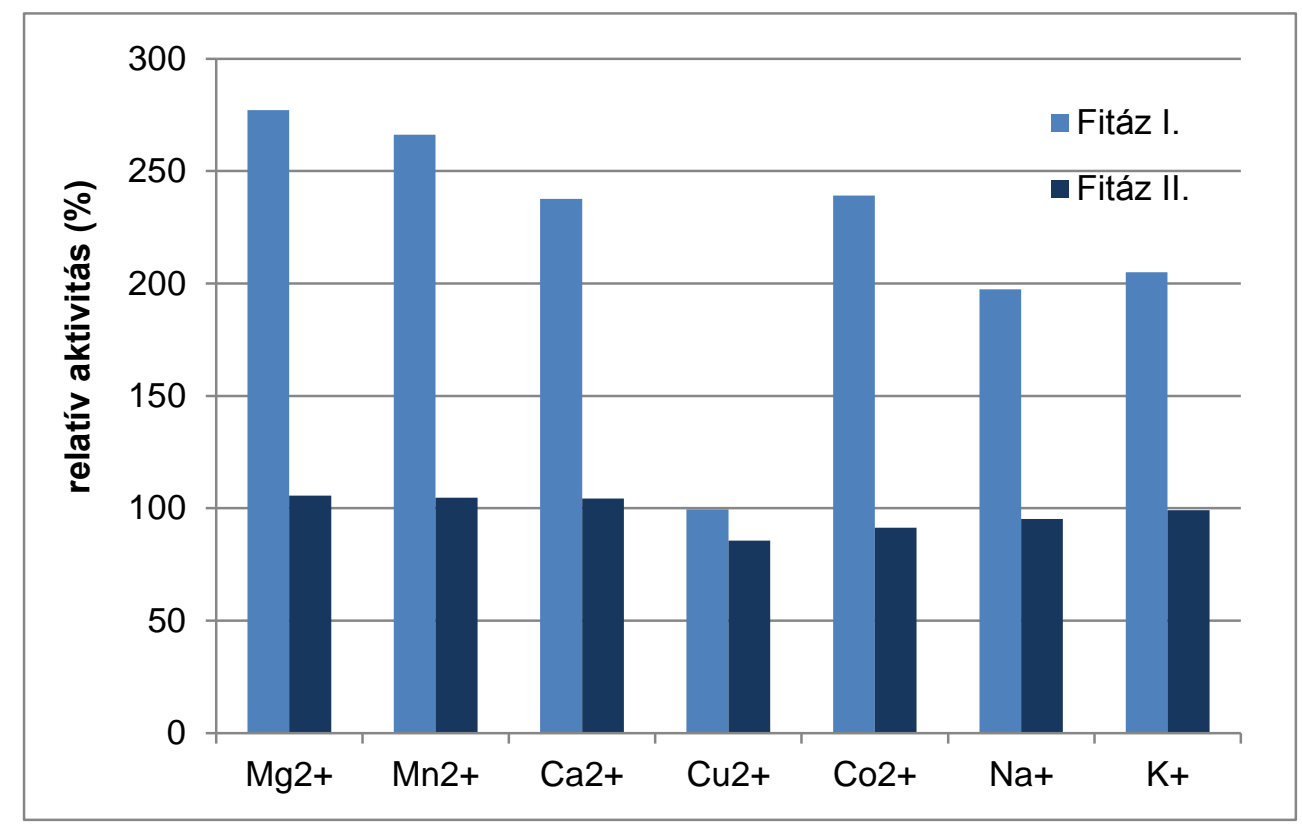

41. ábra. Fémionok hatása az Aspergillus niger eredetű fitáz I. és fitáz II. enzimek aktivitására (Koncentráció: $5 \mathrm{mM}, 60^{\circ} \mathrm{C}, \mathrm{pH}=5$ fitáz I. és $\mathrm{pH}=3,5$ fitáz II. esetén )

Összességében megfigyelhető, hogy a fitáz II. enzimaktivitását kevésbé módosították a fémionok, mint a fitáz I. enzimét, $10 \%$-nál nagyobb eltérés csupán a $\mathrm{Cu}^{2+}$ ion esetében mutatkozott. $\mathrm{A} \mathrm{Cu}^{2+}$ a fitáz II. enzim esetében gátló hatású volt, míg a fitáz I. aktivitását nem befolyásolta, jelenlétében a kontrollal megegyező aktivitás mérhető az adott koncentrációban. SARIYSKA és munkatársai (2005) szintén vizsgálták az ionok hatását A. niger eredetü fitáz enzimnél 100 nmol koncentrációban. Kísérleti eredményeik számos ion esetén megegyeznek az általam kapott eredményekkel: a $\mathrm{Cu}^{2+}$ gátló hatását szintén kimutatták, azonban a $\mathrm{Mn}^{2+}, \mathrm{Zn}^{2+}, \mathrm{Co}^{2+}$

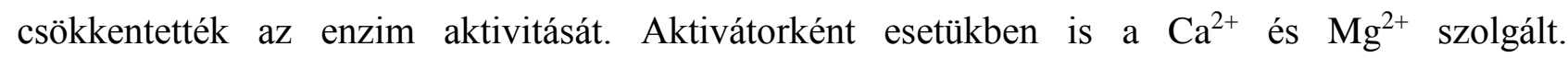


DVORÁKOVÁ munkatársaival (1997) a $\mathrm{Ca}^{2+}, \mathrm{Mg}^{2+}$ és $\mathrm{Mn}^{2+}$ kétvegyértékű ionok aktiváló hatását mutatták ki a vizsgált $A$. niger törzs esetén $0,2 \mathrm{mM}$ koncentrációban, míg a $\mathrm{Cu}^{2+}, \mathrm{Zn}^{2+}, \mathrm{Hg}^{2+}, \mathrm{Sn}^{2+}$, $\mathrm{Cd}^{2+}$ ionok gátolták müködésüket. $\mathrm{Ca}^{2+}$ aktiváló hatása még $5 \mathrm{mM}$ koncentrációban is érvényesült Aspergillus niger van Teighem esetén (VATS \& BANERJEE, 2005). CASEY és WALSH (2003) $200 \mathrm{mM}$ koncentrációban 1,5-szeres aktivitás növekedést tapasztaltak Aspergillus niger ATCC 9142 törzs fitáz enziménél $\mathrm{Mg}^{2+}, \mathrm{Mn}^{2+}, \mathrm{Cu}^{2+}, \mathrm{Cd}^{2+}, \mathrm{Hg}^{2+}, \mathrm{Zn}^{2+}$ ionok jelenlétében, ellenben mérsékelten gátlódott $\mathrm{Ca}^{2+}$ mellett.

\section{7 Új tudományos eredmények}

1. Tizennégy termofil Thermomyces lanuginosus fonalas gomba törzs rangsorolása alapján a legjobbnak ítélt Thermomyces lanuginosus IMI 096218 törzsre fitáz enzim előállítási fermentációs technológiát dolgoztam ki laboratóriumi körülmények között. Fitinsav tartalmú szubsztrátumokon szójaliszt, búzakorpa, kukoricaliszt, rizsliszt - vizsgálva az enzimtermelést, 5\% rizsliszten tapasztaltam kiemelkedő extracelluláris aktivitás értéket. Megállapítottam, hogy Tris-maleát/ $\mathrm{NaOH}$ $\mathrm{pH}=7,5$ pufferrel készítve a tápközeget, $5 \%$ inokulum mennyiséggel indítva a fermentációt, már 2 nap alatt elérhető a maximális enzimaktivitás. Továbbá bizonyítottam, hogy $0,1 \%$ Tween 40 felületaktív anyag alkalmazásával az enzimkiválasztás fokozható (BUJNA et al. 2011).

2. Tizenegy mezofil Aspergillus törzs rangsorolása alapján, a legjobbnak ítélt Aspergillus niger F00735 törzs extracelluláris fitáz enzim elöállítására laboratóriumi fermentációs technológiát dolgoztam ki. Különböző, fitinsav tartalmú természetes szubsztrátumokon - rizsliszt, borsóliszt, kukoricaliszt, kukoricakeményítő, kukoricadara, szójaliszt, búzaliszt és búzadara - vizsgálva az enzimtermelést, szintén rizsliszten értem el kiemelkedő aktivitás értékeket. Központi elrendezésü kísérlettervezési módszerrel optimáltam a tápközeg főbb összetevőit. $0,86 \%$ nátrium-nitrát és 7,1\% rizsliszt alkalmazásával a kiindulási $\mathrm{pH}$ beállítása nélkül az enzimtermelés háromszorosára növekedett (BUJNA et al. 2013).

3. Homogenitásig tisztítottam a Thermomyces lanuginosus IMI 096218 törzs extracelluláris fitáz enzimét. SDS-PAGE gélelektroforézissel egy $60 \mathrm{kDa}$ körüli, valamint egy $90 \mathrm{kDa}$ körüli molekulatömegü sáv különült el, mely alapján feltételezhető, hogy az enzim multimer jellegü. Meghatároztam a tisztított fitáz enzim föbb jellemzőit: a hőmérséklet optimuma: $70{ }^{\circ} \mathrm{C}, \mathrm{pH}$ optimuma $\mathrm{pH}=5,5$ és $\mathrm{pH}=7,5 . \mathrm{A} \mathrm{Fe}^{2+}$ és a $\mathrm{Fe}^{3+} 1 \mathrm{mM}$ koncentrációban, a $\mathrm{K}^{+}$, a $\mathrm{Ca}^{2+}$, és a $\mathrm{Mg}^{2+}$ ionok $5 \mathrm{mM}$ koncentrációban aktivátorként, míg a $\mathrm{Zn}^{2+}$, az $\mathrm{Ag}^{+}$, a $\mathrm{Co}^{2+}$ és a $\mathrm{Cu}^{2+}$ ionok $5 \mathrm{mM}$ koncentrációban gátlólag hatnak az enzim aktivitására. Kinetikai paraméterei: Lineweaver-Burk féle linearizálási módszerrel: $\mathrm{K}_{\mathrm{M}}=0,285 \mathrm{mM}, \mathrm{V}_{\max }=0,126 \mathrm{mM} /$ perc, míg a Hanes-Woolf féle linearizálási módszerrel: $\mathrm{K}_{\mathrm{M}}=0,312 \mathrm{mM}, \mathrm{v}_{\max }=0,132 \mathrm{mM} /$ perc Na-fitát szubsztrátumon. Az enzim 
stabilitásának értékelése céljából meghatároztam annak felezési idejét, mely $54-58^{\circ} \mathrm{C}$ közötti tartományban $\mathrm{pH}=5,0-7,5$ értékek között nagyobb mint 100 perc.

4. Homogenitásig tisztítottam az Aspergillus niger F00735 törzs fitáz enzimét, s két fitáz aktivitással rendelkező fehérjét (fitáz I és fitáz II) kaptam. A tisztított enzimek molekulatömege: 117-120 kDa (fitáz I.) és 65-67 kDa (fitáz II). Az enzimek pH optimuma: fitáz I. esetén pH=5,0, míg fitáz II.-nél pH=2,5-3,5. Mindkét fitáz enzim $60^{\circ} \mathrm{C}$-on mutatta a legnagyobb aktivitást. Ezen a hőmérsékleten a felezési idők fitáz I. esetén 1,5 óra, míg a fitáz II. esetén 54 óra. $50{ }^{\circ} \mathrm{C}$-os hőmérsékleten a fitáz II. 2 hónap elteltével is megőrizte aktivitásának $50 \%$-át. Megállapítottam, hogy a fitáz II. enzimaktivitását a fémionok nem befolyásolták jelentősen. A fitáz I. enzimre $5 \mathrm{mM}$ koncentrációban a legkedvezőbb hatással a $\mathrm{Mg}^{2+}$ és a $\mathrm{Mn}^{2+}$ voltak. 


\section{KÖVETKEZTETÉSEK ÉS JAVASLATOK}

A különböző eredetű fitáz enzimek tulajdonságait, katalitikus és fiziko-kémiai jellemzőit meghatározzák azon szervezetek, amelyből származnak. A mikroorganizmusok diverzitásának köszönhetően a mikrobiális fitázok igen eltérő tulajdonságokat hordozhatnak, így a felhasználási célok támasztotta környezeti feltételeknek megfelelő enzimek gazdag forrásainak tekinthetők. A tápanyagok biofelhasználhatóságának növelése érdekében alkalmazott fitáz készítménnyel szemben elvárás, hogy ellenálljon a gyomor savas pH-jának és az emésztőenzimeknek, ezáltal megfelelően bontsa a fitinsavat a bélben. Továbbá megfelelő stabilitással kell, hogy rendelkezzen a takarmány előállításánál fellépő hőhatással szemben és megőrizze aktivitását. Takarmányozási célra ennek megfelelően az A. niger F00735 törzs fitáz II. enzime ígéretesnek látszik, mivel pH optimuma 2,5 és 3,5 közötti tartományban található, mely $50^{\circ} \mathrm{C}$-on vizsgálva ilyen körülmények között, 2 hónap után is megtartotta aktivitásának felét.

A fitáz enzim újkeletü és fejlődő területe a humán gyógyászatban való alkalmazása. A fitinsavból megfelelő fitáz enzimkészítmények alkalmazásával mioinozit-foszfát intermedierek állíthatók elő, melyek bizonyítottan jótékony élettani hatásúak. A daganatos betegségek kezelésébe való bevonásukról számos kutatási eredmény található, melyekben elsődlegesen a mioinozittrifoszfátoknak tulajdonítanak nagy jelentőséget. A különböző eredetű fitáz enzimek lebontási mechanizmusuk szerint csoportosíthatóak, amelyek lehetnek 3-fitázok, 4/6-fitázok és 5-fitázok. Ezek különböző lebontási útvonalakat, ezáltal különböző szerkezetű mioinozit-foszfátokat eredményezhetnek. A fonalas gomba eredetü fitázokra jellemző, hogy a 3-fitázok közé tartoznak, azonban az elért eredményeim nem elegendőek a tisztított enzimek besorolásához. A téma továbbfejlesztéseként javasolható ezirányú enzimalkalmazási kísérleteket tervezni. A hidrolízis termékek analíziséből következtethetünk az adott enzimek mechanizmusára, továbbá léptéknövelést követően az egyes intermedier termékek preparatív HPLC technológiával elválaszthatóak és szerkezet meghatározásuk NMR technikával elvégezhető. A foszfor csoportok helyzete és jelenléte információt ad az elsődleges támadási helyről, valamint a szekvenciálisan megvalósuló foszfátészterek hidrolíziséről, mely alapján az enzimek besorolása elvégezhető. Ezen ismeretek birtokában lehetővé válhat a biokonverzió során kapott mioinozit-foszfátok gyógyászati tesztelése is.

Kapott eredményeim alapján jelentős különbségeket találtam az A. niger és a Thermomyces lanuginosus eredetű fitáz enzimek között. Tekintve, hogy bőséges irodalmi adat áll rendelkezésünkre az A. niger eredetü fitáz enzimekre vonatkozóan, ezeknek a vizsgálatoknak elvégzése különösen fontos lenne a Thermomyces eredetü enzim esetében is. 


\section{7. ÖSSZEFOGLALÁS}

A növények fontos foszfor raktározó vegyülete a fitát, melyet elsősorban a gabonák, a hüvelyesek és az olajos magvak tartalmaznak. A növényi eredetü takarmányokban a foszfor 60 90\%-ban fitátként van jelen, ami nehezen hozzáférhető az egygyomrú állatok számára, mivel bélrendszerükből - az emberi szervezethez hasonlóan - hiányzik vagy csekély mértékben van jelen a fitinsav bontását végző fitáz enzim. A nagyüzemi állattartásnál a megfelelő foszforbevitel érdekében a takarmányhoz szervetlen foszfort adagolnak, mely szintén nem hasznosul elégséges mértékben és jelentős foszforürítést eredményez. Mindezen tényezők miatt erős a környezet foszfor terhelése, mely a vizek eutrofizációját okozhatja.

A humán táplálkozásban a fitátok antinutritív anyagként ismertek, mivel erős kelátképző tulajdonságuknál fogva, megkötnek számos létfontosságú, kétvegyértékű iont, csökkentve felszívódásukat és hasznosulásukat. A fitátok csökkentik továbbá a fehérjék, a keményítő és a lipidek emészthetőségét, valamint gátolják bizonyos enzimek müködését. A humán táplálkozásban is nagyon fontos szerepet játszó gabonafélékben, hüvelyesekben és olajos magvakban lévő fitát formájában kötött foszfor fitáz alkalmazásával felszabadítható és ezáltal az ásványi anyagok, fehérjék, szénhidrátok hasznosulása is növekszik.

Újabban felismerték, hogy a fitinsav részleges hidrolízisével meghatározott összetételű, egészségmegőrző hatással rendelkező mioinozit-foszfátok állíthatók elő. Ezen vegyületek csökkentik a bélrák kockázatát, a szérum koleszterin szintet és a triglicerid szintet kísérleti állatokban, valamint szerepet játszanak a lipid peroxidáció csökkentésében és antioxidáns hatásuk is jelentős. Ebből kifolyólag a különböző mioinozit-foszfát intermedierek a gyógyításban is szerepet játszhatnak, mely újabb távlatokat nyithat meg funkcionális élelmiszer-összetevőként való alkalmazásra.

A mikroorganizmusok diverzitásából eredően a termelt fitáz enzim tulajdonságai jelentős eltéréseket mutathatnak, ezért céloztam meg egy termofil és egy mezofil fonalas gomba fitáz enzimének előállítását és jellemzését. Kutatómunkám során elvégeztem tizennégy Thermomyces lanuginosus és tizenegy Aspergillus törzs rangsorolását fitáz aktivitásuk alapján. A legjobb fitáz termelő törzsek alkalmazásával fermentációs technológiát dolgoztam ki, majd az enzimek homogenitásig történő tisztítását követően meghatároztam az enzimek jellemző tulajdonságait.

A rendelkezésre álló Thermomyces lanuginosus törzsek rangsorolása után, a legígéretesebbnek talált Thermomyces lanuginosus IMI 096218 törzzsel (25 U/1) tápközeg optimálási kísérletekkel az enzimtermelés fokozását megvalósítottam. A tápközeget $\mathrm{pH}=7,5$ értékü Tris-maleát $/ \mathrm{NaOH}$ pufferrel készítve az enzimaktivitás megnövekedett. Különbözö fitinsav tartalmú anyagok szójaliszt, búzakorpa, kukoricaliszt, rizsliszt - szubsztrátumként való alkalmazásának 
eredményeként rizsliszten kaptam a legnagyobb fitáz aktivitást, melyen az iparban széleskörüen alkalmazott búzakorpához képest 30-szoros fitáz aktivitást értem el szubmerz fermentáció során (317 U/1). Az optimális $5 \%$-os rizsliszt koncentráció és $220 \mathrm{rpm}$ fordulatszám rázatási sebesség alkalmazásával az enzimtermelés tovább növelhető.

Megvizsgáltam a Tween-80, valamint az élesztőkivonat és a citromsav hatását $0,1 \%$ koncentrációban az enzimaktivitás alakulására, mind önmagunkban, mind az összes lehetséges kombinációban. Kimutattam, hogy a kontrollhoz képest a citromsav egyértelműen gátolja a fitáz enzim termelését, az aktivitás közel 90\%-kal csökkent jelenlétében. Tween 80 kiegészítéssel az aktivitás fokozása érhető el. A Tween sorozat további tagjainak aktivitás növelő hatását is megvizsgáltam különböző koncentrációban, s megállapítottam, hogy leggazdaságosabban 0,1% Tween 40 felületaktív anyag alkalmazásával, már 2 nap alatt elérhető a maximális enzimkihozatal. Az inokulálási technikát optimálva, a 40 órás $5 \%$ mennyiséggel történő beoltás eredményezte a legnagyobb fitáz aktivitást. Ezen paraméterek alkalmazásával a maximális aktivitás eléréséhez szükséges fermentációs idő 2 nap. Az optimálási folyamatok eredményeként az enzimaktivitás több mint 50-szeres növelését sikerült megvalósítani (1400-2000U/1).

A Thermomyces lanuginosus IMI 096218 törzzsel optimált körülmények között megvalósított fermentáció tenyészlevéből a fitáz enzim tisztítását a kicsapást követő kromatográfiás eljárások kombinációjával valósítottam meg. A tisztítás során 9,1 tisztulási faktor mellett 5,1\% kitermelést értem el. A kinyert enzim homogenitását SDS-poliakrilamid-gélelektroforézissel ellenőrizve, egy 60 kDa körüli, s egy 90 kDa körüli molekulatömegủ sáv különült el.

A fitáz enzim optimális $\mathrm{pH}-\mathrm{ja}: \mathrm{pH}=5,5$ és $\mathrm{pH}=7,5, \mathrm{~s}$ a maximális aktivitást $70{ }^{\circ} \mathrm{C}$-on mutatja. A T. lanuginosus IMI 096218 törzs fitáz enzimének kinetikai paraméterei Nafitát szubsztrátum alkalmazásával a Lineweaver-Burk féle linearizálási módszerrel: $\mathrm{K}_{\mathrm{M}}=0,285 \mathrm{mM}$, $\mathrm{V}_{\max }=0,126 \mathrm{mM} /$ perc, míg a Hanes-Woolf féle linearizálási módszerrel: $\mathrm{K}_{\mathrm{M}}=0,312 \mathrm{mM}, \mathrm{v}_{\max }=0,132$ $\mathrm{mM}$ /perc. Az enzim 54-58 ${ }^{\circ} \mathrm{C}$ között, $\mathrm{pH}=5,0-7,5$ tartományban a legstabilabb, felezési ideje több mint 100 perc.

A különböző fémionok enzimaktivitást befolyásoló hatásának vizsgálatánál megállapítottam, hogy a $\mathrm{Fe}^{2+}$, a Fe ${ }^{3+} 1 \mathrm{mM}$ koncentrációban, a $\mathrm{K}^{+}$, a $\mathrm{Ca}^{2+}$, és a $\mathrm{Mg}^{2+}$ ionok $5 \mathrm{mM}$ koncentrációban való alkalmazása az aktivitás értékek 13-22\%-os növekedését eredményezték, tehát ezek az ionok

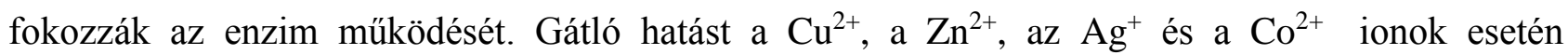
tapasztaltam 5 mM koncentrációban, jelenlétükben a maradék aktivitás 34-55\% volt.

A mezofil Aspergillus fajok törzsei közül az Aspergillus niger F00735 törzs mutatta a legnagyobb fitáz aktivitást. Különböző természetes szubsztrátumok - rizsliszt, borsóliszt, kukoricaliszt, kukoricakeményítő, kukoricadara, szójaliszt, búzaliszt és búzadara - vizsgálatával megállapítottam, hogy a rizsliszt tartalmú tápközegben megvalósított szubmerz fermentációval 
érhető el a legjobb enzim termelés. A legkedvezőbbnek bizonyult nitrogénforrás — a nátrium-nitrát - valamint a rizsliszt, optimális koncentrációjának meghatározásához központi elrendezésü kísérlettervezési módszert használtam. A fermentáció 6. napján elért eredmények alapján a következő modellt kaptam:

$$
z=-846-634 x+50 x^{2}+7712 y-5510 y^{2}+273 x y
$$

ahol z: a fitáz aktivitás [U/1]

$\mathrm{x}$ : a rizsliszt koncentráció $[(\mathrm{w} / \mathrm{v}) \%]$

y: a nátrium-nitrát koncentráció $[(\mathrm{w} / \mathrm{v}) \%]$.

A két faktorról, valamint együttes hatásukról is elmondható, hogy legalább 95\%-os biztonsági szinten enzimtermelést befolyásoló hatásuk van. Összességében a 7,1 (w/v)\% körüli rizsliszt és 0,86 (w/v)\% Na-nitrát javasolható az adott törzzsel fitáz termelésre, s a maximális aktivitás a fermentáció 6 . napján érhető el.

A különböző kiindulási pH nem gyakorolt szignifikáns hatást az enzimtermelésre, ezért nem tartom szükségesnek a kezdeti $\mathrm{pH}$ beállítását. Az inokulum mennyiségi optimálása során megállapítottam, hogy 5 tf\% inokulummal 1000 ml-es lombikban 150 ml fermentációs tápközeget beoltva érhető el a legnagyobb fitáz aktivitás.

Annak ellenére, hogy megfelelő koncentrációban alkalmazva, a felületaktív anyagok általában elősegítik az enzimek kiválasztását, az Aspergillus niger F00735 törzs esetén ez a hatás nem jelentős, és a koncentráció növelésével gátló hatás figyelhető meg. Eredményeim alapján tehát e törzs fitáz fermentációja során felületaktív anyag kiegészítésre nincs szükség.

A T. lanuginosus fitázához hasonlóan a tisztítást kromatográfiás eljárások kombinációjával valósítottam meg, melynek eredményeként két enzimet kaptam, a fitáz I.-t 10,5\%-ban és a fitáz II.-t 4,8\%-ban sikerült kinyerni, 21-szeres illetve 4,7-szeres tisztulást elérve. A fitáz I. molekulatömege 117-120 kDa körüli, míg a fitáz II. molekulatömege 65-67 kDa. A fitáz I. esetén az Aspergillus fajokra gyakran jellemző $\mathrm{pH}=5,0$, míg fitáz II.-nél $\mathrm{pH}=2,5-3,5$ értéknél mérhető a maximális aktivitás. Mindkét fitáz enzim $60^{\circ} \mathrm{C}$-on mutatta a legnagyobb aktivitást. Ezen a hőmérsékleten a fitáz I. 1,5 óráig, míg a fitáz II. 54 óráig megőrizte aktivitásának $50 \%$-át. $50{ }^{\circ} \mathrm{C}$-os hőmérsékleten a fitáz II. aktivitása 2 hónap elteltével sem csökkent $50 \%$ alá.

A fémionok aktivitásra gyakorolt hatásának vizsgálata során megállapítottam, hogy a fitáz II. enzimaktivitását kevésbé módosították a fémionok, mint a fitáz I. enzimét. A fitáz I.-re a legkedvezőbb hatással a $\mathrm{Mg}^{2+}$ és a $\mathrm{Mn}^{2+}$ voltak $5 \mathrm{mM}$ koncentrációban, mely ionok jelenlétében az aktivitás több mint 2,5-szeresére nőtt. $5 \mathrm{mM}$ koncentrációban alkalmazva a $\mathrm{Cu}^{2+}$ fitáz II. esetében gátló hatású volt. 
A 20. táblázatban összefoglaltam az A. niger és a $T$. lanuginosus eredetü fitáz enzimek fermentációs előállítás technológiáját, tisztítási müveleteit, valamint az enzimek jellemzőit. Kutatómunkám eredményei alapján a két különböző eredetü enzimről elmondható, hogy a $T$. lanuginosus IMI 096218 törzs alkalmazásával, rövidebb fermentációs idő alatt (2-4 nap) elérhető a maximális aktivitás, mint az A. niger F00735 törzzsel (6-7 nap). Az inokulum tenyészet felszaporításához szükséges idő mindkét esetben 2 nap, s megegyezik a fermentáció során a legjobb aktivitást eredményező szén- és nitrogénforrás is. A. niger esetén a rizsliszt koncentrációjának 7,1\%-ig való növelésével az enzimtermelés még fokozódott, míg a T. lanuginosus gombánál 5\% rizsliszt volt optimális.

Az A. niger törzzsel megvalósított fermentáció esetén nem szükséges a kezdeti pH beállítása, sem a detergens kiegészítés, mégis nagyobb ez elérhető maximális aktivitás, mint a T. lanuginosus gomba alkalmazásával.

A tisztítási müvelet során a kicsapást követően az Aspergillus esetén 4, míg a Thermomyces esetén 3 kromatográfiás lépés alkalmazásával sikerült megfelelő fehérje elválasztást elérnem és a kapott enzimfrakciók homogénnek bizonyultak. Az optimális hőmérsékleteket összehasonlítva látható, hogy a termofil gomba esetén magasabb, $70^{\circ} \mathrm{C}$ hőmérsékleten maximális az enzimaktivitás, míg a mezofil gombánál szintén magas, $60^{\circ} \mathrm{C}$-os hőmérsékleten mérhető a legnagyobb érték. Ezen a hömérsékleten mind a $T$. lanuginosus, mind az A. niger eredetü fitáz I. enzim felezési ideje 1,5 óra. Ennél nagyobb mértékủ stabilitás tapasztalható fitáz II. esetén, melynek felezési ideje 54 óra $60^{\circ} \mathrm{C}$ on. További előnye, hogy $\mathrm{pH}$ optimuma az erősen savas tartományban található, a legnagyobb aktivitás pedig $\mathrm{pH}=2,5-3,5$ tartományban mérhető. Szintén savas tartomány a $\mathrm{pH}=5-5,5$ érték, mely a legtöbb fitáz enzim pH optimuma, s mely mindkét gombánál is jellemző optimális érték. A $\mathrm{Ca}^{2+}$ és $\mathrm{Mg}^{2+}$ ionok $5 \mathrm{mM}$ koncentrációban alkalmazva, aktivátorai a $T$. lanuginosus, valamint az A. niger fitáz I. enzimének.

Összességében elmondható, hogy mind az A. niger F00735, mind a T. lanuginosus IMI 096218 törzs alkalmazásával rizsliszten megvalósított szubmerz fermentációval extracelluláris fitáz enzim termelhető. A fiziko-kémiai és kinetikai paraméterek ismerete hozzájárul az enzim ipari alkalmazhatóságához akár az élelmiszeriparban vagy a takarmányozás során, továbbá mioinozitfoszfátok célzott létrehozásával gyógyászati területen is. 
20. táblázat $\mathrm{Az}$ A. niger és a $T$. lanuginosus fitáz enzim fermentációs előállítás technológiájának, tisztításának, valamint az enzimek jellemzőinek összehasonlítása

\begin{tabular}{|c|c|c|c|}
\hline \multicolumn{4}{|c|}{ FERMENTÁCIÓS TECHNOLÓGIA } \\
\hline & \multicolumn{2}{|c|}{$\begin{array}{l}\text { Aspergillus niger } \\
\text { F00735 }\end{array}$} & $\begin{array}{c}\text { Thermomyces } \\
\text { lanuginosus } \\
\text { IMI } 096218 \\
\end{array}$ \\
\hline Inokulum kora, mennyisége & \multicolumn{2}{|c|}{2 nap, 5 tf\% } & 2 nap (40 óra) 5 tf\% \\
\hline Fermentáció ideje & \multicolumn{2}{|c|}{ 6-7 nap } & 1-2 nap \\
\hline Fermentáció körülményei & \multicolumn{2}{|c|}{$28^{\circ} \mathrm{C}, 220 \mathrm{rpm}$} & $47^{\circ} \mathrm{C}, 220 \mathrm{rpm}$ \\
\hline Szénforrás & \multicolumn{2}{|c|}{$7,1 \%$ rizsliszt } & $5 \%$ rizsliszt \\
\hline Nitrogénforrás & \multicolumn{2}{|c|}{$0,86 \% \mathrm{NaNO}_{3}$} & $0,86 \% \mathrm{NaNO}_{3}$ \\
\hline Kiindulási $p H$ & \multicolumn{2}{|c|}{$\begin{array}{c}\text { nincs pH állítás } \\
\text { pH=5,3 }\end{array}$} & $\begin{array}{l}\text { Tris-maleát/NaOH puffer } \\
\text { pH=7,5 }\end{array}$ \\
\hline Felületaktív anyag & \multicolumn{2}{|c|}{-} & 0,1\% Tween 40 \\
\hline Max. elért aktivitás & \multicolumn{2}{|c|}{$2000 \mathrm{U} / \mathrm{l}$} & $2000 \mathrm{U} / \mathrm{l}$ \\
\hline \multicolumn{4}{|c|}{ ENZIM KINYERÉS ÉS TISZTÍTÁS } \\
\hline Kicsapás & \multicolumn{2}{|c|}{$\begin{array}{l}\text { ammónium-szulfát } \\
\text { frakcionált kicsapás }\end{array}$} & $\begin{array}{l}\text { ammónium-szulfát } \\
80 \text { \% telítettség }\end{array}$ \\
\hline \multirow{4}{*}{ Kromatográfiás lépések } & \multicolumn{2}{|c|}{ ioncserés kromatográfia } & $\begin{array}{l}\text { hidrofób kölcsönhatású } \\
\text { kromatográfia }\end{array}$ \\
\hline & \multicolumn{2}{|c|}{ gélszűrés } & $\begin{array}{l}\text { hidrofób kölcsönhatású } \\
\text { kromatográfia }\end{array}$ \\
\hline & \multicolumn{2}{|c|}{ kromatofókuszálás } & ioncserés kromatográfia \\
\hline & \multicolumn{2}{|c|}{$\begin{array}{l}\text { hidrofób kölcsönhatású } \\
\text { kromatográfia }\end{array}$} & \\
\hline \multicolumn{4}{|c|}{ ENZIM JELLEMZÉS } \\
\hline & Fitáz I. & Fitáz II. & Fitáz \\
\hline Molekula tömeg & $117-120 \mathrm{kDa}$ & $65-67 \mathrm{kDa}$ & $60 \mathrm{kDa}$ \\
\hline Optimális hömérséklet & \multicolumn{2}{|c|}{$60^{\circ} \mathrm{C}$} & $70^{\circ} \mathrm{C}$ \\
\hline Optimális $p H$ & 5,0 & $2,5-3,5$ & $5,5,7,5$ \\
\hline Felezési idő $t_{1 / 2}\left(60^{\circ} \mathrm{C}\right)$ & $1,5 \mathrm{~h}$ & $54 \mathrm{~h}$ & $1,5 \mathrm{~h}$ \\
\hline Felezési idő $t_{1 / 2}\left(55^{\circ} \mathrm{C}\right)$ & $48 \mathrm{~h}$ & $120 \mathrm{~h}$ & $2,25 \mathrm{~h}$ \\
\hline Aktivátor ( $5 \mathrm{mM})$ & $\begin{array}{l}\mathrm{Mg}^{2+}, \mathrm{Mn}^{2+} \\
\mathrm{Ca}^{2+}, \mathrm{Co}^{2+}\end{array}$ & & $\begin{array}{c}\mathrm{K}^{+}, \mathrm{Ca}^{2+}, \mathrm{Mg}^{2+} \\
\mathrm{Fe}^{2+}(1 \mathrm{mM}), \mathrm{Fe}^{3+}(1 \mathrm{mM})\end{array}$ \\
\hline Inhibitor (5 mM) & & $\mathrm{Cu}^{2+}$ & $\mathrm{Cu}^{2+}, \mathrm{Zn}^{2+}, \mathrm{Ag}^{+}, \mathrm{Co}^{2+}$ \\
\hline
\end{tabular}




\section{SUMMARY}

Phytases catalyse the breakdown of ester linkages in phytate resulting release of bioavailable inorganic phosphorus. In plant, phytic acid is a storage form of phosphorus mainly in cereal grains, legumes and oil seeds. Most plant origin feedstuffs contain from 60 to $90 \%$ of their total phosphorus in phytate form that may pass without chemically unchanged form through the digestive tract of nonruminant animals due to weak or lack of intestinal phytase activity. Therefore in livestock farming especial monogastric farming in one hand the feed must usually be supplemented with inorganic phosphate, whereas in other hand, the phosphorus bounded in phytate or surplus is excreted in animal manure causing environmental problems. The increased emission of phosphorous often contributes to eutrophication of surface waters. Phytate is also classified as an anti-nutritional factor in both human nutrition and animal feeding, because it has the ability to chelate various essential divalent metal ions blocking or slow-down their absorption and utilization. It also able to form complexes with dietary proteins, starch, lipids and inhibits a number of nutritionally important enzymes. As a consequence, treatment with phytase enzyme preparation should increase the bioavailability of proteins, carbohydrates and trace elements in foods and feeds.

Recently, the interest of phytases has turned to other way: the sequential hydrolysis of phytate that results different myo-inositol phosphate intermediates. Some reports are found in the literature dealing with these intermediates that have health promotion and pharmaceutical effects such as reduce a risk of colon cancer, serum cholesterol and triglyceride levels in test animals and lipid peroxidation and act as antioxidants. From this point of view, the myoinositol phosphate intermediates may be applied for medical purposes as well as a functional food ingredient.

Many microorganisms can synthetize phytase(s) during growth. Hence the diversity of microorganisms is very widely, the properties of the phytases vary from species to species even from strain to strain, and thus main goal of this thesis is aimed to the production and characterization of a phytase enzyme from both mesophilic and thermophilic filamentous fungi.

Thermomyces lanuginosus strains were screened for their ability to produce extracellular phytase. T. lanuginosus IMI 096218 proved to be the best one (25 U/l). The enzyme production was enhanced by optimisation of the composition of culture medium and some of the environmental factors. The enzyme activity increased when the medium prepared with TRIS-maleate/NaOH buffer $(\mathrm{pH}=7.5)$. Effects of different natural substrates containing phytate such as soy flour, wheat bran, corn flour, rice flour on phytase production were investigated and the highest activity were achieved on rice flour. The phytase activity was 30 times higher in submerged fermentation on rice flour than on wheat bran, which is widely applied in industry (317 U/l). The optimal rice flour concentration was $5(\mathrm{w} / \mathrm{v}) \%$ and using $220 \mathrm{rpm}$ of the agitation speed for enzyme production can further increase.

Effects of the fermentation media supplemented with various additives such as Tween 80, citric 
acid and yeast extract in $0.1 \%$ concentration both in themselves and in all possible combinations on production of enzyme were investigated. Citric acid clearly inhibits the production of phytase enzyme nearly by $90 \%$. The presence of Tween 80 surfactant enhanced the extracellular phytase activity. Effects of different concentrations of other members of the Tween series were also examined and the best results were obtained in the case of the addition of $0.1 \%$ Tween 40 surfactant to the medium. By optimisation the inoculation technique, the highest phytase activity was achieved after initiation $5 \%$ of 40 hour inoculum. The enzyme yield maximised in $2^{\text {nd }}$ day of the fermentation. As a result of optimization process enzyme activity more than 50 -fold increase was achieved (1400-2000U/l).

The extracellular phytase from T. lanuginosus IMI 096218 strain growing on optimized fermentation conditions were purified by a combination of the chromatographic procedures after the precipitation. The phytase was purified about 9.1 fold with yield of $5.1 \%$. The purified enzyme was checked by polyacrylamide gelelectrophoresis. Two protein bands with a molecular weight approximately of $60 \mathrm{kDa}$ and $90 \mathrm{kDa}$ were detected on SDS-PAGE.

Two optimal $\mathrm{pH}$ values were determined: $\mathrm{pH}=5.5$ and $\mathrm{pH}=7.5$ as well as the maximal activity was measured at $70{ }^{\circ} \mathrm{C}$. Kinetic parameters of phytase originated from $T$. lanuginosus IMI 096218 strain on sodium-phytate substrate were determined by linear Lineweaver-Burk plot: $\mathrm{K}_{\mathrm{M}}=0.285 \mathrm{mM}, \mathrm{v}_{\max }=0.126 \mathrm{mM} / \mathrm{min}$, and Hanes-Woolf plot: $\mathrm{K}_{\mathrm{M}}=0.312 \mathrm{mM}, \mathrm{v}_{\max }=0.132 \mathrm{mM} / \mathrm{min}$. The half-life time of enzyme at temperature $54-58{ }^{\circ} \mathrm{C}$ and $\mathrm{pH}$ range 5.0-7.5 more than $100 \mathrm{~min}$.

Effects of various metal ions on enzyme activity were investigated. The presence of $1 \mathrm{mM}$ $\mathrm{Fe}^{2+}, \mathrm{Fe}^{3+}$ and $5 \mathrm{mM} \mathrm{K}^{+}, \mathrm{Ca}^{2+}$ and $\mathrm{Mg}^{2+}$ ions resulted increase in $13-22 \%$ of activity, whereas the presence of $5 \mathrm{mM} \mathrm{Cu}{ }^{2+}, \mathrm{Zn}^{2+}, \mathrm{Ag}^{+}$and $\mathrm{Co}^{2+}$ ions strongly inhibited the enzyme reaction. In these cases, the residual activities were $34-55 \%$.

Among the tested mesophilic Aspergillus strains the highest phytase activity was achieved by Aspergillus niger F00735. Different natural substrates - rice flour, pea flour, corn flour, corn starch, corn grit, soy flour, wheat flour and wheat grit - were examined in respect of phytase productivity. The rice flour proved to be the best substrate in submerged fermentation. The Central Composite Design (Response Surface Method) were used to determine the optimal concentration of the best nitrogen source - sodium-nitrate - and rice flour. The two factors-, and their combined effects have an impact on influencing the enzyme production at least $95 \%$ confidence level. On the $6^{\text {th }}$ day of fermentation the following model was achieved:

$$
z=-846-634 x+50 x^{2}+7712 y-5510 y^{2}+273 x y
$$

where $\mathrm{z}$ : phytase activity [U/l]

$\mathrm{x}$ : concentration of rice flour $[(\mathrm{w} / \mathrm{v}) \%]$

$\mathrm{y}$ : concentration of sodium-nitrate $[(\mathrm{w} / \mathrm{v}) \%]$. 
Altogether about $7.1(\mathrm{w} / \mathrm{v}) \%$ rice flour and $0.86(\mathrm{w} / \mathrm{v}) \%$ sodium nitrate is recommended for phytase production by the selected strain. The maximal activity is achieved on the $6^{\text {th }}$ day of fermentation. The different initial $\mathrm{pH}$ has not significant effect on enzyme production therefore adjusting pH was not necessary. During optimization of the inoculum size, the highest phytase activity was assayed when $150 \mathrm{ml}$ of fermentation medium in $1000 \mathrm{ml}$ flask was cultured with $5 \%$ by volume of inoculum. Despite of that the surfactants at proper concentration are generally able to promote excretion of enzyme, in the case of A. niger strain F00735 this effect was not significant and what is more the inhibitory effect was observed by increasing the concentration of these compounds.

The purification procedures were performed in combination of different chromatographic steps. Two different enzyme proteins were obtained namely phytase I and II. The yield of the phytase I and the phytase II was $10.5 \%$ and $4.8 \%$, and purification fold 21 and 4.7, respectively.

The molecular weight of phytase I was approximately $117-120 \mathrm{kDa}$ and phytase II 65-67 kDa. The $\mathrm{pH}$ optimum of phytase $\mathrm{I}$ is $\mathrm{pH}=5.0$ that is in agree with ones from Aspergillus species. In the case of phytase II strong acidic optimum $\mathrm{pH}(\mathrm{pH}=2.5-3.5)$ was determined. Both phytases have maximal activity at $60^{\circ} \mathrm{C}$. The half-life times of phytase I and II at $60^{\circ} \mathrm{C}$ were 1.5 hours and 54 hours, respectively. The activity of phytase II did not decrease below $50 \%$ after 2 months at $50{ }^{\circ} \mathrm{C}$. The effect of metal ions on enzyme activity were investigated. The enzyme activity of phytase II was less modified by metal ions, than of phytase $\mathrm{I}$. In the case of phytase $\mathrm{I}$, the $\mathrm{Mg}^{2+}$ and $\mathrm{Mn}^{2+}$ ions at concentration of $5 \mathrm{mM}$ increased the enzyme activity in more than 2.5 times. $5 \mathrm{mM} \mathrm{Cu}^{2+}$ ions had inhibitory effect on enzyme activity of phytase II.

Results of fermentation technology, purification procedures and characterization of phytase enzyme from A. niger and T. lanuginosus are summarized in Table 21. Based on the comparison of the properties of two enzymes from different origins can be established that the application of a $T$. lanuginosus IMI 096218 strain resulted shorter fermentation time (2-4 days) than the A. niger strain F00735 (6-7 days). The times required to propagate the inoculum culture in both cases were two days. Increasing the concentration of rice flour to $7.1 \%$ the enzyme activity of Aspergillus niger phytase was enhanced while in case of T. lanuginosus $5 \%$ of rice flour was optimal. It is not necessary to adjust the initial $\mathrm{pH}$ or apply surfactant during fermentation by A. niger. 
21. Table Comparison of fermentation technology, purification and characterization of phytase enzyme originated from $A$. niger and $T$. lanuginosus

\begin{tabular}{|c|c|c|c|}
\hline \multicolumn{4}{|c|}{ FERMENTATION TECHNOLOGY } \\
\hline & \multicolumn{2}{|c|}{$\begin{array}{l}\text { Aspergillus niger } \\
\text { F00735 }\end{array}$} & $\begin{array}{c}\text { Thermomyces } \\
\text { lanuginosus } \\
\text { IMI } 096218\end{array}$ \\
\hline $\begin{array}{l}\text { Time and quantity of } \\
\text { inoculum }\end{array}$ & \multicolumn{2}{|c|}{2 day, $5(w / v) \%$} & 2 day (40 hour) $5(\mathrm{w} / \mathrm{v}) \%$ \\
\hline Time of fermentation & \multicolumn{2}{|c|}{ 6-7 day } & 1-2 day \\
\hline Fermentation conditions & \multicolumn{2}{|c|}{$28^{\circ} \mathrm{C}, 220 \mathrm{rpm}$} & $47^{\circ} \mathrm{C}, 220 \mathrm{rpm}$ \\
\hline Carbon source & \multicolumn{2}{|c|}{$7.1 \%$ rice flour } & $5 \%$ rice flour \\
\hline Nitrogen source & \multicolumn{2}{|c|}{$0.86 \% \mathrm{NaNO}_{3}$} & $0.86 \% \mathrm{NaNO}_{3}$ \\
\hline Initial $p H$ & \multicolumn{2}{|c|}{$\begin{array}{c}\text { no } \mathrm{pH} \text { adjust needed } \\
(\mathrm{pH}=5.3)\end{array}$} & $\begin{array}{c}\text { Tris-maleate/NaOH buffer } \\
\text { pH=7.5 }\end{array}$ \\
\hline Surfactant & \multicolumn{2}{|c|}{-} & $0.1 \%$ Tween 40 \\
\hline Maximal activity & \multicolumn{2}{|c|}{$2000 \mathrm{U} / \mathrm{l}$} & $2000 \mathrm{U} / \mathrm{l}$ \\
\hline \multicolumn{4}{|c|}{ PURIFICATION OF ENYZME } \\
\hline Precipitation & \multicolumn{2}{|c|}{$\begin{array}{l}\text { ammonium sulphate } \\
\text { fractionation }\end{array}$} & $\begin{array}{l}\text { up to } 80 \% \text { saturation of } \\
\text { ammonium sulphate }\end{array}$ \\
\hline \multirow{4}{*}{ Chromatographic steps } & \multicolumn{2}{|c|}{$\begin{array}{l}\text { ion-exchange } \\
\text { chromatography }\end{array}$} & $\begin{array}{l}\text { hydrophobic interaction } \\
\text { chromatography }\end{array}$ \\
\hline & \multicolumn{2}{|c|}{ gelfiltration } & $\begin{array}{l}\text { hydrophobic interaction } \\
\text { chromatography }\end{array}$ \\
\hline & \multicolumn{2}{|c|}{ chromatofocusing } & $\begin{array}{c}\text { ion-exchange } \\
\text { chromatography }\end{array}$ \\
\hline & \multicolumn{2}{|c|}{$\begin{array}{l}\text { hydrophobic interaction } \\
\text { chromatography }\end{array}$} & \\
\hline \multicolumn{4}{|c|}{ CHARACTERIZATION OF ENZYME } \\
\hline & Phytase I & Phytase II & Phytase \\
\hline Molecular weight & $117-120 \mathrm{kDa}$ & $65-67 \mathrm{kDa}$ & $60 \mathrm{kDa}$ \\
\hline Optimal temperature & \multicolumn{2}{|c|}{$60^{\circ} \mathrm{C}$} & $70^{\circ} \mathrm{C}$ \\
\hline Optimal pH & 5.0 & $2.5-3.5$ & $5.5,7.5$ \\
\hline Half-life time $t_{1 / 2}\left(60^{\circ} \mathrm{C}\right)$ & $1.5 \mathrm{~h}$ & $54 \mathrm{~h}$ & $1.5 \mathrm{~h}$ \\
\hline Half-life time $t_{1 / 2}\left(55^{\circ} \mathrm{C}\right)$ & $48 \mathrm{~h}$ & $120 \mathrm{~h}$ & $2.25 \mathrm{~h}$ \\
\hline Activator ( $5 \mathrm{mM})$ & $\begin{array}{c}\mathrm{Mg}^{2+}, \mathrm{Mn}^{2+} \\
\mathrm{Ca}^{2+}, \mathrm{Co}^{2+}\end{array}$ & & $\begin{array}{c}\mathrm{K}^{+}, \mathrm{Ca}^{2+}, \mathrm{Mg}^{2+} \\
\mathrm{Fe}^{2+}(1 \mathrm{mM}), \mathrm{Fe}^{3+}(1 \mathrm{mM})\end{array}$ \\
\hline Inhibitor ( $5 \mathrm{mM})$ & & $\mathrm{Cu}^{2+}$ & $\mathrm{Cu}^{2+}, \mathrm{Zn}^{2+}, \mathrm{Ag}^{+}, \mathrm{Co}^{2+}$ \\
\hline
\end{tabular}


In both cases of Aspergillus and Thermomyces, homogenous enzyme proteins were obtained after 4 and 3 chromatographical steps following precipitation, respectively. The optimal temperature is higher $\left(70{ }^{\circ} \mathrm{C}\right)$ in the case of thermophilic than of mesophilic $\left(60^{\circ} \mathrm{C}\right)$ fungus. At the optimum temperature the half-life times of phytase from $T$. lanuginosus and the phytase I from $A$. niger were the same (1.5 hours). The half-life time of the phytase II was 54 hour at $60^{\circ} \mathrm{C}$ exhibited high stability. The other advantage of this enzyme is the optimum $\mathrm{pH}$ that was in the strong acidic range of $\mathrm{pH}=2.5-3.5$.

The $\mathrm{Ca}^{2+}$ and $\mathrm{Mg}^{2+}$ ions in concentration of $5 \mathrm{mM}$ activate both phytases from $T$. lanuginosus and phytase I from A. niger.

Altogether it can be concluded that both A. niger F00735 and T. lanuginosus IMI 096218 strains secreted appreciable level of extracellular phytase enzyme on rice flour substrate when doing submerged fermentation. These enzymes exhibited different physico-chemical properties and kinetic parameters puting them to high potential to develop enzyme technology for the industrial application such as (food and feed as well as pharmaceutical industries). 


\section{MELLÉKLETEK}

\section{M1. FELHASZNÁLT IRODALOM}

AFINAH S., YAZID A.M., ANIS SHOBIRIN M.H., SHUHAIMI M. (2010): Phytase: application in food industry. Int. Food Res. J., 17: 13-21. p.

AHMAD, T., RASOOL S., SARWAR M., HAQ A., HASAN Z. (2000): Effect of microbial phytase produced from a fungus Aspergillus niger on bioavailability of phosphorus and calcium in broiler chickens. Animal Feed Sci. Techn., 83: 103-114. p.

DOI: http://dx.doi.org/10.1016/S0377-8401(99)00122-4

AL-ASHEH S. DUVNJAK Z. (1994): The effect of surfactants on the phytase production and the reduction of the phytic acid content in canola meal by Aspergillus carbonarius during a solidstate fermentation process. Biotechnol. Letts. 2: 183-188. p.

DOI: http://dx.doi.org/10.1007/BF01021668

AL-ASHEH S. DUVNJAK Z. (1995): The effect of phosphate concentration on phytase production and the reduction of phytic acid content in canola meal by Aspergillus carbonarius during a solid-state fermentation process. Appl. Microbiol. Biotechnol., 43 (1) 25-30. p.

DOI: http://dx.doi.org/10.1007/BF00170617

AMERSHAM BIOSCIENCES (2002): Gel Filtration: Principles and Methods. Handbook from Amersham Biosciences, Uppsala, Sweden

AMERSHAM BIOSCIENCES (2004): Ion Exchange Chromatography and Chromatofocusing. Handbook from Amersham Biosciences, Uppsala, Sweden

ANDERSON P.A. (1985): Interactions between proteins and constituents that affect protein quality. 31-46. p. In: Finley G.W., Hopkins DT. (Szerk.): Digestibility and Amino Acid Availability in Cereals and Oilseeds. St. Paul: American Association of Cereal Chemists, 304 p.

ANGEL R., TAMIM N.M., APPLEGATE T.J., DHANDU A.S., ELLESTAD L.E. (2002): Phytic acid chemistry: Influence on phytin-phosphorus availability and phytase efficacy. J. Appl. Poult. Res., 11: 471-480. p. DOI: http://dx.doi.org/10.1093/japr/11.4.471

ARIMA K., LIU W.H., BEPPU T. (1972): Studies on the lipase of thermophilic fungus Humicola lanuginosa. Agric Biol Chem. 36: 893-895. p.

ARNESEN S., ERIKSEN S.H., OLSEN J., JENSEN J. (1998): Increased production of $\alpha$-amylase from Thermomyces lanuginosus by the addition of Tween 80. Enzyme Microb. Techn., 23 (34): 249-252. p. DOI: http://dx.doi.org/10.1016/S0141-0229(98)00040-4

BARNA M. (2000): Magyar Táplálékallergia és Táplálékintolerancia Adatbank. Tempus-Phare, 314-319. p.

BARRIER-GUILLOT B., CASADO P., MAUPETIT P., JONDREVILLE C., GATEL F. (1996): Wheat phosphorus availability: 1 - In vitro study; Factors affecting endogenous phytasic activity and phytic phosphorus content. J. Sci. Food Agric., 70: 62-68. p.

BARUAH K., SAHU N.P., PAL A.K., DEBNATH D. (2004): Dietary Phytase: An ideal approach for a cost effective and low-polluting aquafeed. NAGA, WorldFish Center Quarterly, 27 (34):15-19.p. 
BEKÖ S.L., ALIG E., SCHMIDT M.U., VAN DE STREEK J. (2014): On the correlation between hydrogen bonding and melting points in the inositols. International Union of Crystallography, 1: 61-73. p. DOI: http://dx.doi.org/10.1107/S2052252513026511

BENNET JW. (1998): Mycotechnology: the role of fungi in biotechnology. J. Biotechn., 66 (2-3): 101-107 p. DOI: http://dx.doi.org/10.1016/S0168-1656(98)00133-3

BERKA R.M., REY M.W., BROWN K.M., BYUN T., KLOTZ A.V. (1998): Molecular Characterization and Expression of a Phytase Gene from the Thermophilic Fungus Thermomyces lanuginosus. Appl. Environ. Microbiol., 64 (11): 4423-4427. p.

BERRIDGE M.J, IRVINE R.F. (1989): Inositol phosphate and cell signalling. Nature, 341: 198208. p. DOI: http://dx.doi.org/10.1038/341197a0

BHAVSAR K., KUMAR V. R., KHIRE J.M. (2011): High level phytase production by Aspergillus niger NCIM 563 in solid state culture: response surface optimization, up-scaling, and its partial characterization. J. Ind. Microbiol. Biotechnol., 38 (9): 1407-17. p.

BOHN L., MEYER A.S., RASMUSSEN S.K. (2008): Phytate: impact on environment and human nutrition. A challenge for molecular breeding. Journal of Zhejiang University SCIENCE B., 9 (3): 165-191. p. DOI: http://dx.doi.org/10.1631/jzus.B0710640

BOGAR B., SZAKACS G., LINDEN J.C., PANDEY A., TENGERDY R.P. (2003): Optimization of phytase production by solid substrate fermentation. J. Ind. Microb. Biotechnol., 30 (3): 183189. p. DOI: http://dx.doi.org/10.1007/s10295-003-0027-3

BOYCE A., WALSH G. (2007): Purification and characterisation of an acid phospatase with phytase activity from Mucor hiemalis Wehmer. J. Biotechn., 132: 82-87. p.

DOI: http://dx.doi.org/10.1016/j.jbiotec.2007.08.028

BRINCH-PEDERSEN H., OLESEN A., RASMUSSEN S.K., HOLM P.B. (2000): Generation of transgenic wheat (Triticum aestivum L.) for constitutive accumulation of an Aspergillus phytase. Mol. Breed., 6: 195-206. p. DOI: http://dx.doi.org/10.1023/A:1009690730620

BROZOZOWSKI, A.M., SAVAGE, H (2000): Structural origins of the interfacial activation in Thermomyces (Humicola) lanuginosa lipase. Biochem., 39: 15071-15082 p.

DOI: http://dx.doi.org/10.1021/bi0013905

BUJNA, E., SIKLODI, C., REZESSY-SZABÓ, J.M. (2011): Effects of surfactants on production of phytase from Thermomyces lanuginosus. Acta Microbiol. Immunol. Hung., 58: 130. p. DOI: http://dx.doi.org/10.1556/AMicr.58.2011.Suppl.2

BUJNA, E., KUKOVICS, F., NGUYEN, Q.D., REZESSY-SZABÓ, J.M. (2013): Rice flour as potential carbon source for production of phytase by Aspergillus niger. Acta Alim., 42:1-9 p. DOI: http://dx.doi.org/10.1556/AAlim.42.2013.Suppl.1

CAO L., WANG W., YANG C., YANG YI., DIANA J, YAKUPITIYAGE A., LUO Z., LI D. (2007): Application of microbial phytase in fish feed. Enzyme Microb. Technol., 40 (4): 497507. p.

DOI: http://dx.doi.org/10.1016/j.enzmictec.2007.01.007

CARNOVALE E., LUGARO E., BOCCIA L.G. (1988): Phytic acid in faba bean and pea: Effect on protein availability. Cereal. Chem., 65: 114-117. p. 
CASEY A, WALSH G. (2003): Purification and characterization of extracellular phytase from Aspergillus niger ATCC 9142. Biores. Techn., 86: 183-188. p.

DOI: http://dx.doi.org/10.1016/S0960-8524(02)00145-1

CASEY A., WALSH G. (2004): Identification and characterization of a phytase of potential commercial interest. J. Biotechn., 110 (3): 313-322. p.

DOI: http://dx.doi.org/10.1016/j.jbiotec.2004.03.001

CHADHA B.S., GULATI H., MANDEEP M., SAINI H.S., SINGH N. (2004): Phytase production by thermophilic fungus, Rhizomucor pusillus. Word. J. Microbiol. Biotechnol., 20: 105-109. p. DOI: http://dx.doi.org/10.1023/B:WIBI.0000013319.13348.0a

CHENG Z.J., HARDY R.W. (2002): Effects of microbial phytase supplementation on apparent digestibility of barley, canola meal, wheat and wheat middlings, measured in vivo using rainbow, trout (Oncorhynchus mykiss). Aquaculture Nutr., 8: 271-277. p.

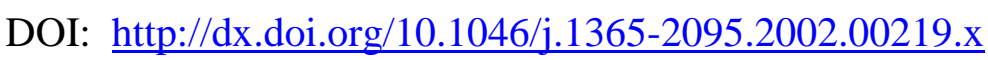

CHERYAN M. (1980): Phytic acid interactions in food systems. Crit. Rev. Food Sci. Nutr. 13: (4) 297-335. p. DOI: http://dx.doi.org/10.1080/10408398009527293

COWIESON A.J., ACAMOVIC T., BEDFORD M.R. (2004): The effects of phytase and phytic acid on the loss of endogenous amino acids and minerals from broiler chickens. British Poultry Sci., 45: (1) 101-108. p. DOI: http://dx.doi.org/10.1080/00071660410001668923

DE RHAM O., JOST T. (1979): Phytate protein interactions in soybean extracts and low-phytate soy protein products. J. Food Sci. 44: 596-600. p. DOI: http://dx.doi.org/10.1111/j.13652621.1979.tb03844.x

DHARMSTHITI S., CHALERMPORNPAISARN S., KIATIYAJARN M., CHANPOKAPAIBOON A., KLONGSITHIDEJ Y. TECHAWIPARUT J. (2004): Phytase production from Pseudomonas putida harbouring Escherichia coli app A. Process Biochem., 40: 789-793. p.

DOI: http://dx.doi.org/10.1016/j.procbio.2004.02.008

DVORÁKOVÁ J, VOLFOVÁ O, KOPECKÝ J. (1997): Characterization of phytase produced by Aspergillus niger. Folia Microbiol. (Praha), 42 (4): 349-352. p.

DOI: http://dx.doi.org/10.1007/BF02816948

EBUNE A., AL-ASHEH S., DUVNJAK Z. (1995): Effects of phosphate, surfactants and glucose on phytase production and hydrolysis of phytic acid in canola meal by Aspergillus ficuum during solid state fermentation. Biores. Technol., 54: 241-247. p. DOI: http://dx.doi.org/10.1016/0960-8524(95)00133-6

EECKHOUT W., DE PAEPE M. (1994): Total phosphorus, phytate-phosphorus and phytase activity in plant feedstuffs. Anim. Feed Sci. Tech., 47: 19-29. p. DOI: http://dx.doi.org/10.1016/0377-8401(94)90156-2

EGGLETON P., PENHALLOW J., CRAWFORD N. (1991): Priming action of inositol hexakisphosphate $\left(\mathrm{InsP}_{6}\right)$ on the stimulated respiratory burst in human neutrophils. Biochim. Biophys. Acta, 1094 (3): 309-316. p. DOI: http://dx.doi.org/10.1016/0167-4889(91)90091-B 
EL-BATAL A.I., KAREM H.A. (2001): Phytase production and phytic acid reduction in rapeseed meal by Aspergillus niger during solid state fermentation. Food Res. Int., 34: 715-720. p. DOI: http://dx.doi.org/10.1016/S0963-9969(01)00093-X

ENGELEN A.J., VAN DER HEEFT F.C., RANDSDORP P.H.G., SMIT E.L.C. (1994): Simple and rapid determination of phytase activity. J. AOAC Int., 77 (3): 760-764. p.

FASSATIOVA O. (1984): Penészek és fonalasgombák az alkalmazott mikrobiológiában. Budapest: Mezőgazdasági Kiadó, 228 p.

FAWOLE O.B., ODUNFA S.A. (2003): Some factors affecting production of pectic enzymes by Aspergillus niger. Int. Biodeter. Biodegr., 52: 223-227. p. DOI: http://dx.doi.org/10.1016/S0964-8305(03)00094-5

FEKETE E., SZABÓ S.A., TÓTH Á. (1991): A vízszennyezés ökológiája. Budapest: ProNatura Kiadó, 192 p.

FEKETE J. GY. (2006): Környezetvédelem mérnököknek. Pécs: Egyetemi jegyzet. 174 p.

FIEDUREK J. 2000. Production of Aspergillus niger catalase under various stress conditions. Acta Microbiol Pol., 49 (1): 43-49. p.

FINDENEGG G.R., NELEMANS J.A. (1993): The effect of phytase on the availability of phosphorus from myo-inositol hexaphosphate (phytate) for maize roots. Plant. Soil., 154: 189196. p.

DOI: http://dx.doi.org/10.1007/BF00012524

FISCHER L., SCHECKERMANN C, WAGNER F. (1995): Purification and characterization of a thermotolerant $\beta$-galactosidase from Thermomyces lanuginosus. Appl Environ Microbiol., 61:1 497-1501. p.

FORSBERG C.W., PHILLIPS J.P., GOLOVAN S.P., FAN M.Z., MEIDINGER R.G., AJAKAIYE A., HILBORN D. HACKER R.R. (2003): The Enviropig physiology, performance, and contribution to nutrient management advances in a regulated environment: the leading edge of change in the pork industry. J. Anim. Sci., 81: E68-E77 p.

FUJITA J., FUKUDA H., YAMANE Y., KIZAKI Y., SHIGETA S., ONO K., SUZUKI O., WAKABAYASHI S. (2001): Critical importance of phytase for yeast growth and alcohol fermentation in Japanese sake brewing. Biotechn. Lett., 23: 867-871. p.

DOI: http://dx.doi.org/10.1023/A:1010599307395

GARGOVA S., ROSHKOVA Z. VANCHEVA G. (1997): Screening of fungi for phytase production. Biotechnology Techniques, 11 (4): 221-224. p. DOI: http://dx.doi.org/10.1023/A:1018426119073

GARGOVA S., SARIYSKA M. (2003): Effect of culture condition on the biosynthesis of Aspergillus niger phytase and acid phosphatase. Enzyme Microb. Technol., 32: 231-235. p. DOI: http://dx.doi.org/10.1016/S0141-0229(02)00247-8

GARGOVA S., SARIYSKA M., ANGELOV A., STOILOVA I. (2006): Aspergillus niger pH 2.1 Optimum Acid Phosphatase with High Affinity for Phytate. Folia Microbiol. 51 (6): 541-545. p.

DOI: http://dx.doi.org/10.1007/BF02931618 
GASZTONYI K., LÁSZTITY R. (1992): Élelmiszerkémia I. Budapest: Mezőgazdasági Kiadó

GEORGE S.P., AHMAD A., RAO M.B. (2001): A novel thermostable xylanase from Thermomonospora sp.: influence of additives on thermostability. Biores. Technol., 78: 221224. p. DOI: http://dx.doi.org/10.1016/S0960-8524(01)00029-3

GEORGE T.S., RICHARDSON A.E., SIMPSON R.J. (2005): Behaviour of plant-derived extracellular phytase upon addition to soil. Soil Biol. Biochem., 37: 977-988. p. DOI: http://dx.doi.org/10.1016/j.soilbio.2004.10.016

GOLOVAN S., HAYES M.A., PHILLIPS J.P., FORSBERG C.W. (2001a): Transgenic mice expressing bacterial phytase as a model for phosphorus pollution control. Nat. Struct. Biol., 19: 429-433. p. DOI: http://dx.doi.org/10.1038/88091

GOLOVAN,S., MEIDINGER R.G., AJAKAIYE A., COTTRILL M., WIEDERKEHR M.Z., BARNEY D.J., PLANTE,C., POLLARD J.W., FAN M.Z., HAYES M.A., LAURSEN J., HJORTH J.P., HACKER' R.R., PHILLIPS J.P., FORSBERG C.W. (2001b) Pigs expressing salivary phytase produce low phosphorus manure. Nat. Biotechn., 19: 741-745. p. DOI: http://dx.doi.org/10.1038/90788

GRAF E., MAHONEY J.R., BRYANT R.G., EATON J.W. (1984): Iron-catalysed hydroxyl radical formation. Stringent requirement for free iron coordination site. J. Biol. Chem., 259: 3620. p.

GREINER R., KONIETZNY U. (2006): Phytase for Food Application. Food Technol. Biotechnol., 44 (2): 125-140. p. DOI: http://dx.doi.org/10.1590/S1517-838220090004000010

GREINER R., DA SILVA L.G., COURI S. (2009): Purification and characterisation of an extracellular phytase from Aspergillus niger 11T53A9. Brazilian J. Microbiol., 40: 795-807. p.

GRUBER K., KLINTSCHAR G., HAYN M., SCHLACHER A., STEINER W., KRATKY, C. (1998): Thermophilic xylanase from Thermomyces lanuginosus: High resolution X-ray structure and modeling studies. Biochemistry, 37: 13475-13485. p.

GULATI H.K., CHADHA B.S., SAINI H.S. (2007a): Production and characterization of thermostable alkaline phytase from Bacillus laevolacticus isolated from rhizosphere soil. $\underline{J}$. Ind. Microbiol. Biotechnol., 34 (1) : 91-98. p. DOI: http://dx.doi.org/10.1021/bi9808641

GULATI H.K., CHADHA B.S., SAINI H.S. (2007b): Production, purification and characterisation of Thermomyces lanuginosus TL-7. Acta Microbiol. Immunol. Hung., 54 (2): 121-128. p. DOI: http://dx.doi.org/10.1556/AMicr.54.2007.2.3

GULATI H.K., CHADHA B.S., SAINI H.S. (2007c): Production of Feed Enzymes (Phytase and Plant Cell Wall Hydrolyzing Enzymes) by Mucor indicus MTCC 6333: Purification and Characterization of Phytase. Folia Microbiol., 52 (5): 491-497. p.

DOI: http://dx.doi.org/10.1007/BF02932109

GUPTA S.D., MAHESHWARI R. (1985): Is organic acid required for nutrition of thermophilic fungi. Arc. Microbiol., 141: 164-169. p. DOI: http://dx.doi.org/10.1007/BF00423279

HA N.C., OH B.C, SHIN S., KIM H.J., OH T.K., KIM Y.O., CHOI K.Y., OH, B.H. (2000): Crystal structures of a novel, thermostable phytase in partially and fully calcium-loaded states. Nature Structural \& Molecular Biology, 7: 147-153. p. DOI: http://dx.doi.org/10.1038/72421 
HAEFNER S., KNIETSCH A., SCHOLTEN E., BRAUN J., LOHSCHEIDT M., ZELDER O. (2005): Biotechnological production and application of phytase. Appl. Microbiol. Biotechnol. 68: 588-597. p. DOI: http://dx.doi.org/10.1007/s00253-005-0005-y

HAJÓS GY. (2008): Élelmiszerkémia. Budapest: Akadémiai Kiadó. 636 p.

HALLBERG L., ROSSANDER L., SKÅNBERG A.B. (1987): Phytates and the inhibitory effect of bran on iron absorption in man. Am. J. Clin. Nutr., 45 (5): 988-996. p.

HAN Y., LEI X.G. (1999): Role of glycosylation in the functional expression of an Aspergillus niger phytase (phyA) in Pichia pastoris. Arch. Biochem. Biophys., 364: 83-90. p.

DOI: http://dx.doi.org/10.1006/abbi.1999.1115

HARLAND B.F., MORRIS E.R. (1995): Phytate: A good or a bad food component? Nutr. Res., 15 (5): 733-754. p. DOI: http://dx.doi.org/10.1016/0271-5317(95)00040-P

HAROS M, ROSELL CM, BENEDITO C. (2001): Use of fungal phytase to improve breadmaking performance of whole wheat bread. J. Agric. Food Chem., 49 (11): 5450-4. p. DOI: http://dx.doi.org/ 10.1021/jf0106421

HAROS M., CARLSSON N.G., ALMGREN A., LARSSON-ALMINGER M., SANDBERG A.S., ANDLID T. (2009): Phytate degradation by human gut isolated Bifidobacterium pseudocatenulatum ATCC27919 and its probiotic potential. Int. J. Food Microbiol., 135: 7-14. p. DOI: http://dx.doi.org/10.1016/j.ijfoodmicro.2009.07.015

HASSAN S., ALTAFF K., SATYANARAYANA T. (2009): Use of Soybean Meal Supplemented with Cell Bound Phytase for Replacement of Fish Meal in the Diet of Juvenile Milkfish, Chanos chanos. Pakistan Journal of Nutrition, 8 (4): 341-344. p.

HASSOUNI H., ISMAILI-ALAOUI M., GAIME-PERRAUD I., AUGUR C., ROUSSOS S. (2006): Phytase production by the thermophilic fungus Myceliophthora thermophila in solid state fermentation. Micología Aplicada International, 18 (2): 29-36. p.

HAWKSWORTH D.L., KIRSOP B.E., JONG S.C. (1988): Filamentous Fungi. Cambridge: Cambridge University Press, 224 p.

HEINONEN J.K., LAHTI R.J. (1981): A new and convenient colorimetric determination of inorganic orthophosphate and its application to the assay of inorganic pyrophosphatase. Analytical Biochemistry, 113 (2): 313-317. p. DOI: http://dx.doi.org/10.1016/0003$\underline{2697(81) 90082-8}$

HESZKY L., FÉSÜS L., HORNOK L. (2005): Mezőgazdasági Biotechnológia. Budapest: Agroinform Kiadó 366 p.

HONG C.Y., CHENG K.J., TSENG T.H., WANG C.S., LIU L.F., YU S.M. (2004): Production of two Highly Active Bacterial Phytases with broad $\mathrm{pH}$ optima in germinated transgenic rice seeds. Transgenic Res., $13 \quad$ (1): $29-39 . \quad$ p. $\quad$ DOI: http://dx.doi.org/10.1023/B:TRAG.0000017158.96765.67

HONIG B., NICHOLLS A. (1995): Classical electrostatics in biology and chemistry. Science, 268 (5214): 1144 -1149. p. DOI: http://dx.doi.org/10.1126/science.7761829

HURRELL R.F., JUILLERAT M.A., REDDY M.B., LYNCH S.R., DASSENKO S.A., COOK J.D. (1992): Soy protein, phytate, and iron absorption in humans. Am. J. Clin. Nutr., 56 (3): 573-8. p. 
IN M-J., SEO S-W., KIM D.C., OH N-S. (2009): Purification and biochemical properties of an extracellular acid phytase produced by the Saccharomyces cerevisiae CY strain. Process Biochem., 44: 122-126. p. DOI: http://dx.doi.org/10.1016/j.procbio.2008.10.006

IQBAL T.H., LEWIS K.O., COOPER B.T. (1994): Phytase activity in the human and rat small intestine. Gut, 35: 1233-1236. p.

JAKUCS E., VAJNA L. (2003): Mikológia, Budapest: Agroinform Kiadó, 514 p.

JAVED M.M., AHMED W., ZAHOOR S., HAQ I.U. (2010): Solid state culturing of thermophilic fungi for phytase production. Pak. J. Bot., 42 (5): 3605-3611. p.

JENAB M., THOMPSON L.U. (2002): Role of Phytic Acid in Cancer and Other Diseases. 225248. p. In: Reddy N.R., Sathe, S.K. (Szerk.) Food Phytates. Boca Raton-London-New YorkWashington: CRC Press. 280 p.

JOHANSEN C.L., COOLEN L., HUNIK J.H. (2008): Influence of Morphology on Product Formation in Aspergillus awamori during Submerged Fermentations. Biotechnology Progress., 14 (2): 233-240. p. DOI: http://dx.doi.org/10.1021/bp980014x

JONGBLOED A.W., MROZ Z., VAN DER WEIJ-JONGBLOED R., KEMME P.A. (2000): The effects of microbial phytase, organic acids and their interaction in diets for growing pigs. Livestock Production Science., 67: 113-122. p. DOI: http://dx.doi.org/10.1016/S0301$\underline{6226(00) 00179-2}$

KAMINI N.R., MALA J.G.S., PUVANAKRISHNAN R. (1998): Lipase production from Aspergillus niger by solid-state fermentation using gingelly oil cake. Process Biochem., 33 (5): 505-511. p. DOI: http://dx.doi.org/10.1016/S0032-9592(98)00005-3

KEITH G.T., COLIN R.T. (1992): Mycelial morphology: The effect of spore inoculum level. Biotechn. Lett., 14 (11): 1071-1074. p.

KEROVUO J., LAURAEUS M., NURMINEN P., KALKKINEN N., APAJALAHTI J. (1998): Isolation characterization molecular gene cloning and sequencing of a novel phytase from Bacillus subtilis. Appl. Environ. Microbiol., 64: 2079-2085. p.

KEROVUO J. (2000): A Novel Phytase from Bacillus. Characterization and Production of the Enzyme. Finland. Academic dissertation 69 p.

KIM D.S., GODBER J.S., KIM H.R. (1999): Culture conditions for a new phytase-producing fungus. Biotechn. Lett., 21: 1077-1081. p. DOI: http://dx.doi.org/10.1023/A:1005696829168

KIM Y.O., KIM H.K., BAE K.S., YU J.H., OH T.K. (1998): Purification and properties of a thermostable phytase from Bacillus sp DS11. Enzyme Microb. Techn., 22 (1): 2-7. p. DOI: http://dx.doi.org/10.1016/S0141-0229(97)00096-3

KLABUNDE T., STAHL B., SUERBAUM H., HAHNER S., KARAS M., HILLENKAMP F., KREBS B., WITZEL H. (1994): The amino acid sequence of the red kidney bean Fe(III)-Zn(II) purple acid phosphatase. Eur. J. Biochem., 226: 369-375. p. DOI: http://dx.doi.org/10.1111/j.1432-1033.1994.tb20061.x

KNOWLTON K.F., RADCLIFFE J.S., NOVAK C.L., EMMERSON D.A. (2004): Animal management to reduce phosphorus losses to the environment. J. Anim. Sci., 82: 173-195. p. 
KONA R.P., QURESHI N., PAI J.S. (2001): Production of glucose oxidase using Aspergillus niger and corn steep liquor. Biores. Technol., 78: 123-126. p. DOI: http://dx.doi.org/10.1016/S0960$\underline{\text { 8524(01)00014-1 }}$

KONIETZNY U., GREINER R. (2002): Molecular and catalytic properties of phytate-degrading enzymes (phytases). Int. J. Food Sci. Techn., 37: 791-812. p. DOI: http://dx.doi.org/10.1046/j.1365-2621.2002.00617.x

KONIETZNY U., GREINER R. (2003): Phytic acid: Nutritional impact. 4555-4563. p. In: Caballero B., Trugo L., Finglas P. (Szerk.) Encyclopaedia of food science and nutrition, London: Elsevier.

KUMAR V., SINHA A.K., MAKKAR H.P.S., BECKER K. (2010): Dietary roles of phytate and phytases in human nutrition: A review. Food Chem., 120: 945-959. p.

DOI: http://dx.doi.org/10.1016/j.foodchem.2009.11.052

LAEMMLI U.K. (1970): Cleavage of structural proteins during the assembly of the head of bacteriophage T4. Nature 227: 680-685. p. DOI: http://dx.doi.org/10.1038/227680a0

LAMBRECHTS C., BOZE H., MOULIN G., GALZY P. (1992): Utilization of phytate by some yeasts. Biotechnol. Lett., 14: 61-66. p. DOI: http://dx.doi.org/10.1007/BF01030915

LARSSON M., MINEKUS M., HAVENAAR R. (1997): Estimation of the Bioavailability of Iron and Phosphorus in Cereals using a Dymamic In Vitro Gastrointestinal Model. J. Sci. Food Agric., 74: 99-106. p. DOI: http://dx.doi.org/10.1002/(SICI)1097-0010(199705)74:1<99::AIDJSFA775>3.0.CO;2-G

LEI X.G., STAHL C.H. (2001): Biotechnological development of effective phytases for mineral nutrition and environmental protection. Appl. Microbiol. Biotechnol., 57: 474-481. p. DOI: http://dx.doi.org/10.1007/s002530100795

LEI X.G., PORRES J.M. (2003): Phytase enzymology, applications, and biotechnology. Biotechn. Lett., 25: 1787-1794. p. DOI: http://dx.doi.org/10.1023/A:1026224101580

LI J., HEGEMAN C.E., HANLON R.W., LACY G.H., DENBOW D.M., GRABAU E.A. (1997): Secretion of active recombinant phytase from soybean cellsuspension cultures. Plant Physiol., 114: 1-9. p. DOI: http://dx.doi.org/10.1104/pp.114.3.1103

LI C.Y., CHENG C.Y., CHEN T.L. (2001): Production of Acinetobater radioresistent lipase using Tween 80 as the carbon source. Enzyme Microb. Tech., 29: 258-263. p.

DOI: http://dx.doi.org/10.1016/S0141-0229(01)00396-9

LIANG J, HAN B.Z, NOUT M.J.R., HAMER R.J. (2009): Effect of soaking and phytase treatment on phytic acid, calcium, iron and zinc in rice fractions. Food Chem., 115 (3): 789-794. p.

DOI: http://dx.doi.org/10.1016/j.foodchem.2008.12.051

LIAO W., LIU Y., FREAR,C., CHEN S. (2007a): A new approach of pellet formation of a filamentous fungus - Rhizopus oryzae. Biores. Technol., 98 (18): 3415-3423. p. DOI: http://dx.doi.org/ 10.1016/j.biortech.2006.10.028

LIAO W., LIU Y., CHEN S. (2007b): Studying pellet formation of a filamentous fungus Rhizopus oryzae to enhance organic acid production. Appl. Biochem. Biotechnol., 137: 689-701. p. DOI: http://dx.doi.org/10.1007/978-1-60327-181-3_56 
LIEBERT F., PORTZ L. (2007): Different sources of microbial phytase in plant based low phosphorus diets for Nile tilapia Oreochromis niloticus may provide different effects on phytate degradation. Aquaculture, 267: 292-299. p. DOI: http://dx.doi.org/ 10.1016/j.aquaculture.2007.01.023

LIENER I.E. (1994): Implications of Antinutritional Components in Soybean Foods. Crit. Rev. Food Sci. Nutr., 34: 31-67. p. DOI: http://dx.doi.org/10.1080/10408399409527649

LIU B.L., RAFIQ A., TZENG Y.M., ROB A. (1998): The induction and characterization of phytase and beyond. Enzyme Microb. Technol., 22: 415-424. p.

DOI: http://dx.doi.org/10.1016/S0141-0229(97)00210-X

LIU Q., LI Q, JIANG L, ZHANG D, WANG H., GU M., YAO Q. (2006): Transgenic Expression of the Recombinant Phytase in Rice (Oryza sativa). Rice Science, 13 (2): 79-84. p.

LOEWUS F. (2002): Biosynthesis of phytate in food grains and seeds. 53-61 p. In: Reddy N.R., Sathe S.K. (Szerk.), Food phytates. Boca Raton, Florida, USA: CRC Press. 280 p.

LOPEZ H.W., LEENHARDT F., COUDRAY C., REMESY C. (2002): Minerals and phytic acid interactions: is it a real problem for human nutrition? Int. J. Food Sci. Techn., 37: 727-739. p. DOI: http://dx.doi.org/10.1046/j.1365-2621.2002.00618.x

LÓPEZ J.L., PÉREZ J.A.S., SEVILLA J.M.F., PORCEL E.M.R., CHISTI Y. (2005): Pellet morphology, culture rheology and lovastatin production in cultures of Aspergillus terreus. J. Biotechnol., 116: 61-77. p. DOI: http://dx.doi.org/10.1016/j.jbiotec.2004.10.005

MAHESHWARI R., BHARADWAJ G., BHAT M.K. (2000): Thermophilic Fungi: Their Physiology and Enzymes. Microbiol. Mol. Biol. Rev., 64 (3): 461-488. p.

DOI: http://dx.doi.org/10.1128/MMBR.64.3.461-488.2000

MANDVIWALA T.N., KHIRE J.M. (2000): Production of high activity thermostable phytase from thermotolerant Aspergillus niger in solid state fermentation. J. Industr. Microbiol. Biotechnol., 24: 237-243. p. DOI: http://dx.doi.org/10.1038/sj.jim.2900811

MIDORIKAWA K., MURATA M., OIKAWA S., HIRAKU Y., KAWANISHI S. (2001): Protective effect of phytic acid on oxidative DNA damage with reference to cancer chemoprevention. Biochem. Biophys. Res. Commun., 288 (3): 552-7. p.

DOI: $\underline{\text { http://dx.doi.org/10.1006/bbrc.2001.5808 }}$

MISSET O. (2003): Phytase. 687-706. p. In: WHITAKER J.R., VORAGEN A.G.J., WONG D.W.S. (Szerk.) Handbook of food enzymology. New York, USA: Dekker. 1052 p.

MOREIRA M.T., SANROMAIN A., FEIJOO G., LEMA J.M. (1996): Control of pellet morphology of filamentous fungi in fluidized bed bioreactors by means of a pulsing flow. Application to Aspergillus niger and Phanerochaete chrysosporium. Enzyme Microb. Technol., 19: 261-266. p. DOI: http://dx.doi.org/10.1016/0141-0229(95)00244-8

MOSER M., PÁLMAI GY. (1996): A Környezetvédelem alapjai. Budapest: Aqua Kiadó. 512 p.

MROZ Z., JONGBLOED A.W., KEMME P. (1994): Apparent digestibility and retention of nutrients bound to phytate complexes as influenced by microbial phytase and feeding regimen in pigs. J. Anim. Sci., 72: 126-132. p.

MUKHTAR H., IKRAM-UL-HAQ.( 2009): Production of Acid Protease by Aspergillus niger Using Solid State Fermentation. Pakistan J. Zool., 41 (4): 253-260. p. 
MULLANEY E.J., DALY C.B., ULLAH A.H. (2000): Advances in phytase research. Adv. Appl. Microbiol. 47: 157-199. p.

MULLANEY E.J., ULLAH,A.H.J. (2005): Phytases: attributes, catalytic mechanisms and applications. Inositol Phosphates in the Soil-Plant-Animal System: Linking Agriculture and Environment. Book of Abstract, 17-18. p.

MULLANEY E.J., LOCOVARE H., SETHUMADHAVAN K., BOONE S., LEI X.G., ULLAH A.H.J. (2010): Site-directed mutagenesis of disulfide bridges in Aspergillus niger NRRL 3135 phytase (PhyA), their expression in Pichia pastoris and catalytic characterization. Appl. Microbiol. Biotechnol., 87: 1367-1372. p. DOI: http://dx.doi.org/10.1007/s00253-010-2542-2

NAGASHIMA T., TANGE T., ANAZAWA H. (1999): Dephosphorylation of phytate by using the Aspergillus niger phytase with a high affinity for phytate. Appl. Environ. Microbiol., 65 (10): 4682-4684. p.

NAKAMURA Y., FUKUHARA H., SANO K. (2000): Secreted phytase activities of yeasts. Biosci. Biotechnol. Biochem. 64 (4): 841-844. p. DOI: http://dx.doi.org/10.1271/bbb.64.841

NAMPOOTHIRI K.M., TOMES G.J., ROOPESH K., SZAKACS G., NAGY V., SOCCOL C.R., PANDEY A. (2004): Thermostable Phytase Production by Thermoascus aurantiacus in Submerged Fermentation. Appl. Biochem. Biotechn., 118: 206-214. p.

DOI: http://dx.doi.org/10.1385/ABAB:118:1-3:205

NAYNI N.R., MARKAKIS P. (1986): Phytases. In: Graf E. (Szerk.): Phytic Acid: Chemistry and Applications. Minneapolis: Pilatus Press, 344 p.

NEMEC T., JERNEJC K. (2002): Influence of Tween 80 on lipid metabolism of an Aspergillus niger strain. Appl. Biochem. Biotechnol., 101 (3): 229-238. p.

DOI: http://dx.doi.org/10.1385/ABAB:101:3:229

NIELSEN K.F., MOGENSEN J. M., JOHANSEN M., LARSEN T.O., FRISVAD J.C. (2009): Review of secondary metabolites and mycotoxins from the Aspergillus niger group. Anal. Bioanal. Chem., 395 (5): 1225-1242. p. DOI: http://dx.doi.org/10.1007/s00216-009-3081-5

NGUYEN D.Q., REZESSY-SZABÓ J.M, HOSCHKE Á. (2000): Optimisation of Composition of Media for the Production of Amylolytic Enzymes by Thermomyces lanuginosus ATCC 34626. Food Technol. Biotechnol, 38 (3): 229-234. p.

OH B.C., CHANG B.S., PARK K.H., HA N.C., KIM H.K., OH B.H., OH T.K. (2001): Calciumdependent catalytic activity of a novel phytase from Bacillus amyloliquefaciens DS11. Biochem. 40 (32): 9669-76. p. DOI: http://dx.doi.org/10.1021/bi010589u

OH B.B., CHOI W.C., PARK S., KIM Y.O., OH, T.K. (2004): Biochemical properties and substrate specificities of alkaline and histidine acid phytases. Appl. Microbiol. Biotechnol, 63: 362-372. p. DOI: http://dx.doi.org/10.1007/s00253-003-1345-0

OKADA G. (1988): Cellulase of Aspergillus niger. Methods Enzymol.,160: 259-264. p.

DOI: http://dx.doi.org/10.1016/0076-6879(88)60128-5

PABON M., LÖNNERDAL B. (1992): Effect of citrate on zinc bioavailability from milk, milk fractions and infant formulas. Nutr. Res., 13: 103-111. p.

DOI: http://dx.doi.org/10.1016/S0271-5317(05)80661-X 
PALACIOS M.C., HAROS M., ROSELL C.M., SANZ Y. (2008a): Selection of phytate-degrading human bifidobacteria and application in whole wheat dough fermentation. Food Microbiol., 25 (1): 169-76. p. DOI: http://dx.doi.org/10.1016/j.fm.2007.06.001

PALACIOS M.C., HAROS M., SANZ Y., ROSELL C.M. (2008b): Selection of lactic acid bacteria with high phytate degrading activity for application in whole wheat breadmaking. Food Sci. Technol., 41 (1): 82-92. p. DOI: http://dx.doi.org/10.1016/j.lwt.2007.02.005

PALACIOS M.C., HAROS M., SANZ Y., ROSELL C.M. (2008c): Phytate degradation by Bifidobacterium on whole wheat fermentation. Eur. Food Res. Tech., 226: 825-831. p.

DOI: http://dx.doi.org/10.1007/s00217-007-0602-3

PAPAGIANNI M., NOKES S.E., FILER K. (1999): Production of phytase by Aspergillus niger in submerged and solid-state fermentation. Process Biochem., 35: 397-402. p.

DOI: http://dx.doi.org/10.1016/S0032-9592(99)00088-6

PAPAGIANNI M., MATTEY M. (2006): Morphological development of Aspergillus niger in submerged citric acid fermentation as a function of the spore inoculum level. Application of neural network and cluster analysis for characterization of mycelial morphology. Microbial Cell Factories, 5 (3): 1-12. p. DOI: http://dx.doi.org/10.1186/1475-2859-5-3

PASAMONTES L., HAIKER M., WYSS M., TESSIER M., VAN LOON A.P.G.M. (1997): Gene cloning, purification, and characterization of a heat-stable phytase from the fungus Aspergillus fumigatus. Appl. Environ. Microbiol., 63 (5): 1696-1700. p.

PHILLIPPY B.Q. (1998): Purification and Catalytic Properties of a Phytase from Scallion (Allium fistulosum L.) Leaves. J. Agric. Food Chem., 46 (9): 3491-3496. p.

DOI: http://dx.doi.org/10.1021/jf9803177

PHILLIPPY B.Q., WYATT C.J. (2001): Degradation of Phytate in Foods by Phytases in Fruit and vegetable extracts. J. Food Sci., 66 (4): 535-539. p. DOI: http://dx.doi.org/10.1111/j.13652621.2001.tb04598.x

PLAAMI S. (1997): Myoinositol Phosphates: Analysis, Content in Food and Effects in Nutrition. Lebensm. - Wiss u. - Technol. 30: 633-647. p. DOI: http://dx.doi.org/10.1006/fstl.1997.0246

RAUEN H.M. (1964): Biochemisches Taschenbuch. Berlin-Gottingen-Heidelberg-New York: Springer-Verlag. 89-121 p. DOI: http://dx.doi.org/10.1007/978-3-642-53240-5

RAVINDRAN V., BRYDEN W.L., KORNEGAY E.T. (1995): Phytates: occurrence, and implications in poultry nutrition. Poultry Avian Biol. Rev., 6: 125-143. p.

REDDY B.S. (1999): Prevention of colon carcinogenesis by components of dietary fiber. Anticancer Res., 19 (5A): 3681-3. p.

REDDY B.S., HIROSE Y., COHEN L.A., SIMI B., COOMA I., RAO C.V. (2000): Preventive potential of wheat bran fractions against experimental colon carcinogenesis: implications for human colon cancer prevention. Cancer Res., 60 (17): 4792-4797. p.

REILlY P., SWEENEY T., SMITH A.G., PIERCE K.M., GAHAN D.A., CALLAN J.J., O'DOHERTY J.V. (2010): The effects of cereal-derived $\beta$-glucans and enzyme supplementation on intestinal microbiota, nutrient digestibility and mineral metabolism in pigs. Livest. Sci. 133 (1-3): 144-147. p. DOI: http://dx.doi.org/10.1016/j.livsci.2010.06.048 
REZESSY-SZABÓ J.M., NGUYEN, Q.D., HOSCHKE, A., BRAET, C., HAJOS, GY., CLAEYSSENS, M. (2007): A novel thermostable alpha-galactosidase from the thermophilic fungus Thermomyces lanuginosus CBS 395.62/b: purification and characterization. Biochim. Biophys. Acta, 1770: 55-62. p. DOI: http://dx.doi.org/10.1016/j.bbagen.2006.06.022

RODLER I. (2005): Új tápanyagtáblázat. Budapest: Medicina Könyvkiadó Zrt., 765 p.

ROOPESH K., RAMACHANDRAN S., NAMPOTHIRI K.M., SZAKACS G., PANDEY A. (2006): Comparison of phytase production on wheat bran and oilcakes in solid-state fermentation by Mucor racemosus. Biores. Techn., 97 (3) : 506-511. p.

DOI: http://dx.doi.org/10.1016/j.biortech.2005.02.046

RUTTENBERG K.C. (2001): Phosporous cycle. In: STEELE J.H., THORPE S.A., TUREKIAN K.K. (Szerk.): Encyclopedia of Ocean Sciences. Academic Press. 3399 p.

SANDBERG A.S., HULTHÉN L. R., TÜRK M. (1995): Dietary Aspergillus niger Phytase Increases Iron Absorption in Humans. J. Nutr., 126 (2): 476-80. p.

SANO L., FUKUHARA H., NAKAMURA Y. (1999): Phytase of the yeast Arxula adeninivorans. Biotechnol. Lett., 21: 33-38. p. DOI: http://dx.doi.org/10.1023/A:1005438121763

SARIYSKA M.V., GARGOVA S.A., KOLEVA L.A., ANGELOV A.I. (2005): Aspergillus niger phytase: purification and characterization. Biotechnol. \& Biotechnol., 19: 98-105. p. DOI: http://dx.doi.org/10.1080/13102818.2005.10817235

SCHAFER A, KOPPE W.M., MEYER-BURGDORFF K.H. GÜNTHER K.D. (1995): Nutritional Effects of a microbial phytase on the utilization of native phosphorus by carp in a diet based on soybean meal. Water Science and Technology, 31 (10): 149-155. p. DOI: http://dx.doi.org/10.1016/0273-1223(95)00434-O

SCHUSTER E. DUNN-COLEMAN N., FRISVAD J.C., VAN DIJCK P.W.M. (2002): On the safety of Aspergillus niger - a review. Appl. Microb. Biotechn., 59: 426-435. p. DOI: http://dx.doi.org/10.1007/s00253-002-1032-6

SCIGELOVA M., CROUT D.H.G. (2000): Purification of $\alpha$-galactosidase from Aspergillus niger for application in the synthesis of complex oligosaccharides. J. Mol. Catalysis B: Enz., 8: 175181. p. DOI: http://dx.doi.org/10.1016/S1381-1177(99)00055-7

SEGUEILHA L., LAMBRECHTS C., BOZE H., MOULIN G., GALZY P. (1992): Purification and properties of the phytase from Schwanniomyces castellii. J. Ferment. Bioeng., 74 (1): 7-11. p. DOI: http://dx.doi.org/ 10.1016/0922-338X(92)90259-W

SELLE P.H., RAVINDRAN V. (2007): Microbial phytase in poultry nutrition. Animal Feed Science and Technology, 135 (1-2): 1-41. $\quad$ p. $\quad$ DOI: http://dx.doi.org/10.1016/j.anifeedsci.2006.06.010

SELLE P.H., COWIESON A.J., RAVINDRAN V. (2009): Consequence of calcium interaction with phytate and phytase for poultry and pigs. Livestock Science, 124: 126-141. p. DOI: http://dx.doi.org/ 10.1016/j.livsci.2009.01.006

SHAMSUDDIN A.M. ULLAH A. (1989): Inositol hexaphosphate inhibits large intestinal cancer in F344 rats 5 months after induction by azoxymethane. Carcinogenesis, 10: 625-626. p. DOI: http://dx.doi.org/10.1093/carcin/10.3.625 
SHAMSUDDIN A. M. (1995): Inositol phosphates have novel anticancer function. J. Nutr., 125: 725S-732S. p.

SHAMSUDDIN A.M., VUCENIK I., COLE K.E. (1997): IP 6 : A novel anti-cancer agent. Life Sciences, 61 (4): 343-354. p. DOI: http://dx.doi.org/10.1016/S0024-3205(97)00092-1

SHEARS S.B. (1998): The versatility of inositol phosphates as cellular signals. Biochimica et Biophysica Acta, 1436: 49-67. p. DOI: http://dx.doi.org/10.1016/S0005-2760(98)00131-3

SHEPPY C. (2001): The Current Feed Enzyme Market and Likely Trends. 1-11. p. In: BEDFORD, M.R., PARTRIDGE, G.G. (Szerk.): Enzymes in farm animal nutrition. CABI Publising, 407 p. DOI: http://dx.doi.org/10.1079/9780851993935.0001

SHI X.W., SUN M.L., ZHOU B., WANG X.Y. (2009): Identification, characterization, and overexpression of a phytase with potential industrial interest. Can J Microbiol. 55 (5): 599-604. p. DOI: http://dx.doi.org/10.1139/w09-008

SHIEH TR., WARE J.H. (1968): Survey of Microorganisms for the Production of Extracellular Phytase. Applied Microbiology, 16 (9): 1348-1351. p.

SHIEH T.R., WODZINSKI R.J. WARE J.H. (1969): Regulation of the Formation of Acid Phosphatases by Inorganic Phosphate in Aspergillus ficuum. J. Bacteriol., 100 (3): 1161-1165. p.

SHIMIZU M. (1993) Purification and characterization of phytase and acid phosphatase produced by Aspergillus oryzae K1. Biosci. Biotechnol. Biochem. 57: 1364-1365. p. DOI: http://dx.doi.org/10.1271/bbb.57.1364

SIMPSON C.J., WISE A. (1990): Binding of zinc and calcium to inositol phosphates (phytate) in vitro. British J. Nutr., 64: 225-232. p. DOI: http://dx.doi.org/10.1079/BJN19900024

SINGH S., MADLALA A.M., PRIOR B.A. (2003): Thermomyces lanuginosus: properties of strains and their hemicellulases. FEMS Microbiology Reviews, 27: 3-16. p.

DOI: http://dx.doi.org/10.1016/S0168-6445(03)00018-4

SINGH R.P., AGARWAL R. (2005): Prostate Cancer and Inositol Hexaphosphate: Efficacy and Mechanisms. Anticancer Research, 25: 2891-2904. p.

SINGH B., KAUR P., SATYANARAYANA T. (2006): Fungal Phytases in Ameliorating Nutritional Status of Foods and Combating Environmental Phopshorus Pollution. 289-326. p. In: Chauhan A.K., Varma A. (Szerk.): Microbes: Health and Environment, I. K. International Pvt Ltd, 436 p.

SINGH B., SATYANARAYANA T. (2008): Phytase production by Sporotrichum thermophile in a cost-effective cane molasses medium in submerged fermentation and its application in bread. $J$. Appl. Microbiol., 105: 1858-1865. p. DOI: http://dx.doi.org/10.1111/j.13652672.2008.03929.x

SINGH B., SATYANARAYANA T. (2009): Characterization of a HAP-phytase of a thermophilic mould Sporotrichum thermophile. Biores. Technol., 100 (6): 2046-51. p. DOI: http://dx.doi.org/10.1016/j.biortech.2008.10.025

SINGH B., SATYANARAYANA T. (2010): Plant Growth Promotion by an Extracellular HAPPhytase of a Thermophilic Mold Sporotrichum thermophile. Appl. Biochem. Biotechn., 160: 5 1267-1276 p. DOI: http://dx.doi.org/10.1007/s12010-009-8593-0. 
SINGH B., KUNZE G., SATYANARAYANA T. (2011): Developments in biochemical aspects and biotechnological applications of microbial phytases. Biotechn. Molecular Biol. Rev., 6 (3): 69-87. p.

SINGH B., SATYANARAYANA T. (2011): Phytases from thermophilic molds: Their production, characteristics and multifarious applications. Proc. Biochem., 46 (7): 1391-1398. p.

DOI: http://dx.doi.org/10.1016/j.procbio.2011.03.009

SINGH B., SATYANARAYANA T. (2012): Production of phytate-hydrolyzing enzymes by thermophilic moulds. African J. Biotechn., 11: (59) 12314-12324. p.

DOI: http://dx.doi.org/10.5897/AJB12.695

SOMASUNDAR P., RIGGS D.R., JACKSON B.J., CUNNINGHAM C., VONA-DAVIS L., MCFADDEN D.W. (2005): Inositol Hexaphosphate (IP6): A Novel Treatment for Pancreatic Cancer. J. Surgic. Res., 126: 199-203. p. DOI: http://dx.doi.org/10.1016/j.jss.2005.01.022

SONI S.K., KHIRE J.M. (2007): Production and partial characterization of two types of phytase from Aspergillus niger NCIM 563 under submerged fermentation conditions. World J. Microbiol. Biotechnol., 23: 1585-1593. p. DOI: http://dx.doi.org/ 10.1007/s11274-007-9404-9

SONI S.K., MAGDUM A., KHIRE, J.M. (2010): Purification and characterization of two distinct acidic phytases with broad $\mathrm{pH}$ stability from Aspergillus niger NCIM 563. World J. Microbiol. Biotechnol., 26: 2009-2018. p. DOI: http://dx.doi.org/10.1007/s11274-010-0385-8

SUZUKI U., YOSHIMURA K., TAKAISHI M. (1907): Ueber ein enzym phytase das anhydro-oxymethilen diphosphorusaure spaltet. Bulletin of the College of Agriculture, 7: 503-512. p.

SVENSSON B., LARSEN K., GUNNARSSON A. (1986): Characterization of a glucoamylase G2 from Aspergillus niger. Eur. J. Biochem., 154 (3): 497-502. p.

DOI: http://dx.doi.org/10.1111/j.1432-1033.1986.tb09425.x

TANG J., LEUNG A., LEUNG C., LIM B.L. (2006): Hydrolysis of precipitated phytate by three distinct families of phytases. Soil Biology and Biochemistry, 38(6): 1316-1324. p.

DOI: http://dx.doi.org/ 10.1111/j.1432-1033.1986.tb09425.x

TOMSCHY A., TESSIER M., WYSS, M., BRUGGER R.C.B., SCHNOEBELEN L., VAN LOAN A.P.G.M., PASAMONTES L. (2000): Optimization of the catalytic properties of Aspergillus fumigatus phytase based on the three-dimensional structure. Protein Sci., 9: 1304-1311. p. DOI: http://dx.doi.org/10.1110/ps.9.7.1304

TSUI M.M., YORK J.D. (2010): Roles of inositol phosphates and inositol pyrophosphates in development, cell signaling and nuclear processes. Advances in Enzyme Regulation, 50: 324337. p. DOI: http://dx.doi.org/10.1016/j.advenzreg.2009.12.002

TUOMELA M., VIKMAN M., HATAKKA A., ITÄVAARA M. (2000): Biodegradation of lignin in a compost environment: a review. Biores. Techol., 72: 169-183. p.

DOI: http://dx.doi.org/10.1016/S0960-8524(99)00104-2

TURNER B.J., PAPHÁZY M.J., HAYGARTH P.M., MCKELVIE I.D. (2002): Inositol phosphate in the environment. Phil. Trans. R. Soc. Lond. B., 357: 449-469. p.

DOI: http://dx.doi.org/10.1098/rstb.2001.0837

ULLAH A.H.J., GIBSON D.M. (1987): Extracellular phytase (E.C. 3.1.3.8) from Aspergillus ficuum NRRL 3135: purification and characterization. Prep. Biochem., 17: 63-91. p. 
DOI: http://dx.doi.org/10.1080/00327488708062477

ULLAH A.H., CUMMINS B.J. (1987): Purification, N-terminal amino acid sequence and characterization of $\mathrm{pH} 2.5$ optimum acid phosphatase (E.C. 3.1.3.2) from Aspergillus ficuum. Prep. Biochem., 17: 397-422. p. DOI: http://dx.doi.org/10.1080/00327488708062504

ULLAH A.H., MULLANEY E.J. (1996): Disulfide bonds are necessary for structure and activity in Aspergillus ficuum phytase. Biochem. Biophys. Res. Commun. 227 (2): 311-317. p.

DOI: http://dx.doi.org/10.1006/bbrc.1996.1506

UM J.S., PAIK I.K. (1999): Effects of Microbial Phytase Supplementation on Egg Production, Eggshell Quality, and Mineral Retention of Laying Hens Fed Different Levels of Phosphorus. Poultry Sci., 78: 75-79. p. DOI: http://dx.doi.org/10.1093/ps/78.1.75

VAN ETTEN R.L., DAVIDSON R., STEVIS P.E., MACARTHUR H,. MOORE D.L. (1991): Covalent structure, disulfide bonding, and identification of reactive surface and active site residues of human prostatic acid phosphatase. J. Biol. Chem., 266 (4): 2313-2319. p.

VAN SUIJDAM J.C., KOSSEN N.W.F., PAUL P.G. (1980): An Inoculum Technique for the Production of Fungal Pellets. European J. Appl. Microbiol. Biotechnol., 10: 211-221. p. DOI: http://dx.doi.org/

VATS P., BANERJEE U.C. (2002): Studies on the production of phytase by a newly isolated strain of Aspergillus niger van teigham obtained from rotten wood logs. Proc. Biochem., 38: 211217. p. DOI: http://dx.doi.org/10.1007/BF00508608

VATS P., BANERJEE U.C. (2004): Production studies and catalytic properties of phytases (myoinositolhexakisphosphate phosphohydrolases): an overview. Enzyme Microb. Technol., 35: 3-14. p. DOI: http://dx.doi.org/10.1016/j.enzmictec.2004.03.010

VATS P., BANERJEE U.C. (2005): Biochemical characterisation of extracellular phytase (myoinositol hexakisphosphate phosphohydrolase) from a hyper-producing strain of Aspergillus niger van Teighem. J. Ind. Microbiol. Biotechnol., 232 (4): 141-7. p.

DOI: http://dx.doi.org/10.1007/s10295-005-0214-5

VERGHESE M., RAOB D.R., CHAWANA C.B., WALKERA L.T., SHACKELFORD L. (2006): Anticarcinogenic effect of phytic acid (IP6): Apoptosis as a possible mechanism of action. LWT, 39: 1093-1098. p. DOI: http://dx.doi.org/10.1016/j.lwt.2005.07.012

VERWOERD T.C., VAN PARIDON P.A., VAN OOYEN AJJ., VAN LENT JWM., HOEKEMA A., PEN J. (1995): Stable Accumulation of Aspergillus niger Phytase in Transgenic Tobacco Leaves. Plant Physiology, 109 (4): 1199-1205. p. DOI: http://dx.doi.org/10.1104/pp.109.4.1199

VOHRA A., SATYANARAYANA T. (2001): Phytase production by the yeast Pichia anomala. Biotechnology Letters, 23: 551-554. p. DOI: http://dx.doi.org/10.1023/A:1010314114053

VOHRA A., SATYANARAYANA T. (2003): Phytases: Microbial sources, production, purification and potential biotechnological applications. Crit. Rev. Biotech., 23: 29-60. p.

DOI: http://dx.doi.org/10.1080/713609297

VUCENIK I., SAKAMOTO K., BANSAL M., SHAMSUDDIN A.M. (1993): Inhibition of rat mammary carcinogenesis by inositol hexaphosphate (phytic acid). A pilot study. Cancer Lett., 75 (2): 95-102. p. DOI: http://dx.doi.org/10.1016/0304-3835(93)90193-D 
WANG Y., GAO X., SU Q., WU W., AN L. (2007): Cloning, expression, and enzyme characterization of an acid heat-stable phytase from Aspergillus fumigatus WY-2. Curr Microbiol., 55 (1): 65-70. p. DOI: http://dx.doi.org/10.1007/s00284-006-0613-5

WEAVER C.M., KANNAN, S. (2002): Phytate and mineral bioavailability. 211-224. p. In: REDDY N.R., SATHE, S.K. (Szerk.): Food Phytates. Boca Raton-London-New YorkWashington: CRC Press. 280 p.

WODZINSKI R.J., ULLAH A.H.J. (1996): Phytase. Adv. Appl. Microbiol., 42: 263-302. p.

WYSS M., BRUGGER R., KRONENBERGER A., REMY R., FIMBEL R., OESTERHELT G., LEHMANN M., VAN LOON A.P.G.M. (1999a): Biochemical characterization of fungal phytases (myo-inositol exakisphosphate phosphohydrolase): Catalytic properties. App. Environ. Microbiol. 65 (2): 367-373. p.

WYSS M., PASAMONTES L., FRIEDLEIN A., RÉMY R., TESSIER M., KRONENBERGER A., MIDDENDORF A., LEHMANN M., SCHNOEBELEN L., RÖTHLISBERGER U., KUSZNIR E., WAHL G., MÜlleR F., LAHM H.W., VOGEL K., VAN LOON A.P. (1999b): Biophysical characterization of fungal phytases (myo-inositol hexakisphosphate phosphohydrolases): molecular size, glycosylation pattern, and engineering of proteolytic resistance. Appl. Environ. Microbiol., 65 (2): 359-66. p.

WYSS M., PASAMONTES L., RÉMY R., KOHLER J., KUSZNIR E., GADIEN, M., MULLER F., VAN LOON A.P.G.M. (1998): Comparison of the Thermostability Properties of Three Acid Phosphatases from Molds: Aspergillus fumigatus Phytase, A. niger Phytase, and A. niger $\mathrm{pH}$ 2.5 Acid Phosphatase. Appl. Environ. Microbiol., 64 (11): 4446-4451. p.

YALKOWSKY S.H. (1999): Solubility and Solubilization in Aqueous Media. New York: Oxford University Press, $496 \mathrm{p}$.

YAMAMOTO S., MINODA Y., YAMADA K. (1972): Chemical and physicochemical properties of phytase from Aspergillus terreus. Agric. Biol. Chem., 36: 2097-2103. p.

YI Z., KORNEGAY E.T., RAVINDRAN V., LINDEMANN M.D., WILSON J.H. (1996): Effectiveness of Natuphos ${ }^{\circledR}$ phytase in improving the bioavailabilities of phosphorus and other nutrients in soybean meal-based semipurified diets for young pigs. J. Anim. Sci., 74: 16011611.p.

YOUNG L.G., LEUNISSEN M., ATKINSON J.L. (1993): Addition of microbial phytase to diets of young pigs. J. Anim. Sci. 71: 2147-2150. p.

ZHANG G.Q., DONG X.F., WANG Z.H., ZHANG Q., WANG H.X., TONG J.M. (2010): Purification, characterization, and cloning of a novel phytase with low $\mathrm{pH}$ optimum and strong proteolysis resistance from Aspergillus ficuum NTG-23. Biores. Technol., 11: 4125-31. p.

DOI: http://dx.doi.org/10.1016/j.biortech.2010.01.001

ZHOU X-L., SHEN W., ZHUGE J., WANG Z-X. (2006): Biochemical properties of a thermostable phytase from Neurospora crassa. FEMS Microbiology Letters, 258 (1): 61-66. p.

DOI: http://dx.doi.org/10.1111/j.1574-6968.2006.00205.x

ZIMMERMANN B, LANTZSCH H.J., MOSENTHIN R., SCHOENER F.J., BIESALSKI H.K., DROCHNER W. (2002): Comparative evaluation of the efficacy of cereal and microbial phytases in growing pigs fed diets with marginal phosphorus supply. J. Sci. Food. Agric., 82: 1298-1304. p. DOI: http://dx.doi.org/10.1002/jsfa.1190 
ŽNIDARŠIČ P., KOMEL R., PAVKO A. (2000): Influence of some environmental factors on Rhizopus nigricans submerged growth in the form of pellets. World Journal of Microbiology \& Biotechnology, 16: 589-593. p. DOI: http://dx.doi.org/10.1023/A:1008967519157

1. http://books.google.hu/books?id=x13NiCGHMt8C\&lpg=PA372\&ots=mNMg8H5Ylf\&dq=first \%20in\%20enzyme\%20technology\%20Anons\%201999\&hl=hu\&pg=PA359\#v=onepage \&q=first\%2 0in\%20enzyme\%20technology\%20Anons\%201999\&f=false

2. http://books.google.hu/books?id=ZTOlo0G65hcC\&pg=PA67\&lpg=PA67\&dq=Andlid+phytate+ Saccharomyces\&source=bl\&ots=9VgeSKT7jr\&sig=weIf2p4Xh14LR0OxL4ZbNWHedx0\&hl=hu\& ei=xbl2TYXEF4rCswb36LmCBQ\&sa=X\&oi=book_result\&ct=result\&resnum=5\&ved=0CEAQ6A EwBDgK\#v=onepage \&q=Andlid\%20phytate\%20Saccharomyces $\& \mathrm{f}=$ false 


\section{KÖSZÖNETNYILVÁNÍTÁS}

Ezúton is szeretném hálásan megköszönni Rezessyné Szabó Judit egyetemi magántanárnak, témavezetőmnek, hogy a kezdetektől felkarolt, tapasztalatával, szakmai és baráti tanácsaival terelgette hosszú utam mind a PhD tanulmányaim során, mind az életben. Tiszteletreméltó tudásával, alaposságával, a szakmai és a hallgatói iránti szeretetével mindig jó példával szolgált.

Köszönöm Hoschke Ágoston professzor emeritus és Hegyesné Vecseri Beáta egyetemi docens tanszékvezetőknek, hogy lehetőséget biztosítottak kutatásaim elvégzésére és támogattak munkám kiteljesedésében.

Köszönöm a Sör- és Szeszipari Tanszék további oszlopos tagjainak Nguyen Duc Quangnak, Sárváriné Szöllősi Mártának, Panyik Gábornénak, Kiss Zsuzsannának, Kun Szilárdnak és Kun-Farkas Gabriellának, valamint Tanszékünk többi munkatársának is, hogy állandó baráti, vidám légkört teremtettek a kutatásokhoz és a mindennapokhoz.

Köszönöm hallgatóim lelkes munkáját, akik részt vettek a fonalas gomba eredetü fitáz enzimek felderítésében, név szerint: Szappanos Judit, Szalma Anikó, Kozma László, Siklodi Cecília, Varga Emese, Kukovics Ferenc, valamint Dobondi Cecília, hogy munkájukkal hozzájárultak dolgozatom eredményeihez.

Szeretném megköszönni férjemnek, Quangnak, hogy értékes szakmai tanácsai mellett az élet minden területén támogatott, bíztatott és mellettem állt.

Továbbá Édesanyám és gyermekeim Zsófia és Dániel megértő türelmét és boldogító szeretetüket. 